\title{
LOW-FLOW CHARACTERISTICS OF STREAMS IN MARYLAND AND DELAWARE
}

By David H. Carpenter and Donald C. Hayes

U.S. GEOLOGICAL SURVEY

Water-Resources Investigations Report 94-4020

Prepared in cooperation with the

MARYLAND GEOLOGICAL SURVEY

and the

MARYLAND WATER RESOURCES ADMINISTRATION

with the partial support of the

DELAWARE GEOLOGICAL SURVEY

and the

DELAWARE DEPARTMENT OF NATURAL RESOURCES AND

ENVIRONMENTAL CONTROL 


\section{U.S. DEPARTMENT OF THE INTERIOR \\ BRUCE BABBITT, Secretary \\ U.S. GEOLOGICAL SURVEY}

Gordon P. Eaton, Director

For additional information write to:

District Chief

U.S. Geological Survey, WRD

208 Carroll Building

8600 La Salle Road

Towson, MD 21286
Copies of this report can be purchased from:

U.S. Geological Survey

Earth Science Information Center

Open-File Reports Section

Box 25286, MS 517

Denver Federal Center

Denver, CO 80225-0046 


\section{CONTENTS}

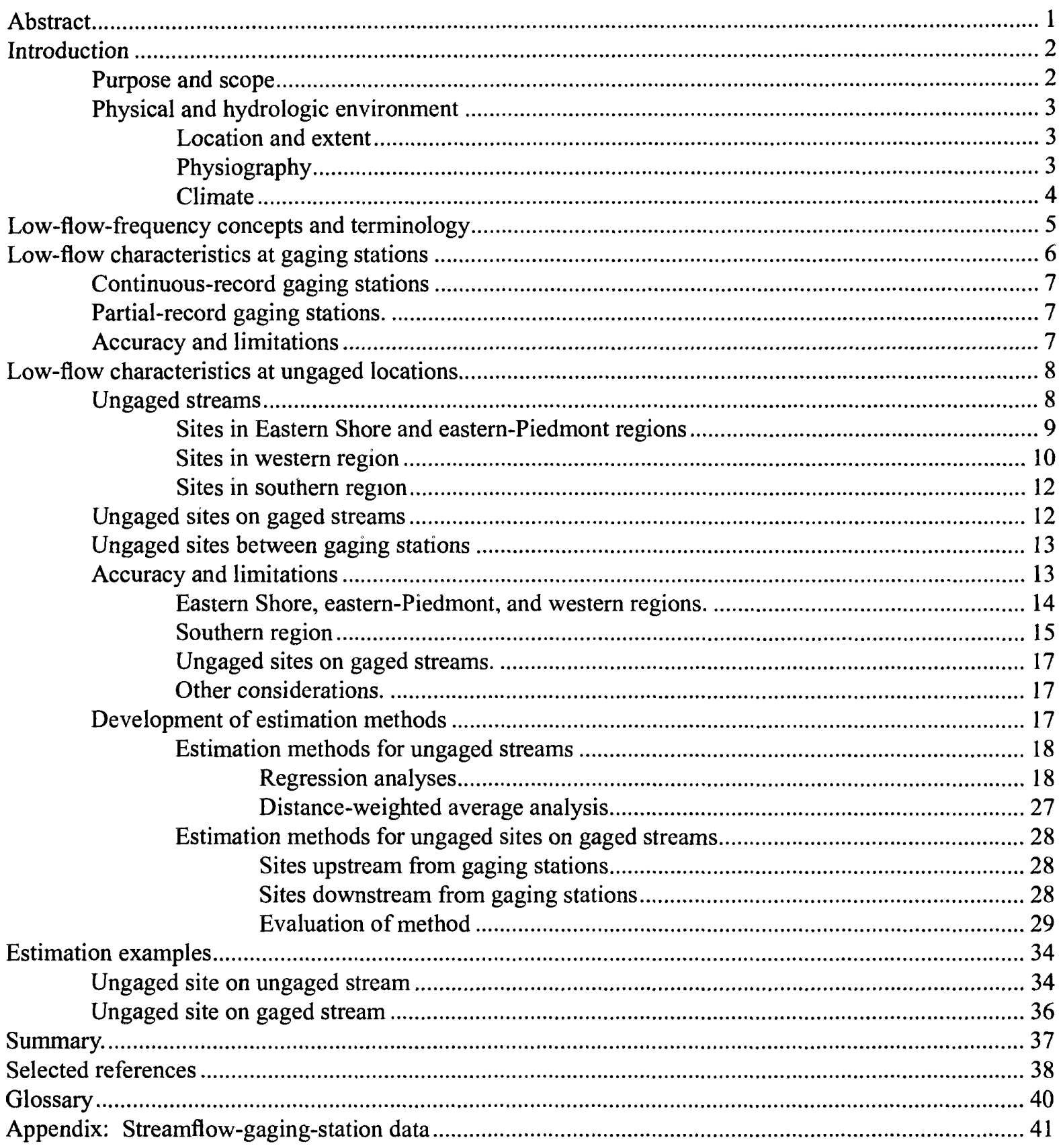




\section{PLATES}

1. Map of Delaware, Maryland, and parts of Pennsylvania, Virginia, and West Virginia showing hydrologic regions and location of streamflow-gaging stations.

2-10. Maps showing extent of type A and type D soils in:

2. Caroline County, Maryland.

3. Cecil County, Maryland.

4. Dorchester County, Maryland.

5. Kent County, Maryland.

6. Queen Annes County, Maryland.

7. Somerset County, Maryland.

8. Talbot County, Maryland.

9. Wicomico County, Maryland.

10. Worcester County, Maryland.

\section{FIGURES}

1-2. Maps showing:

1. Physiographic provinces of Maryland and Delaware

2. Mean annual precipitation in Maryland, Delaware, and adjacent States................................. 5

3. Graph showing relation of area underlain by carbonate rocks to ratios of observed to predicted 7-day, 10-year low-flow estimates in western region of Maryland.

4-6. Maps showing location of paired streamflow-gaging stations in:

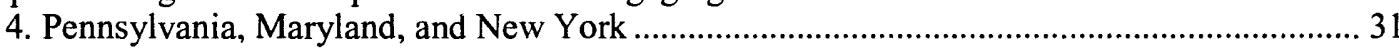

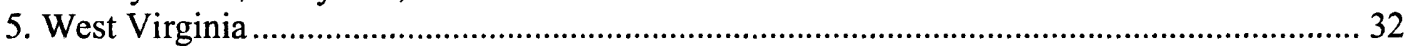

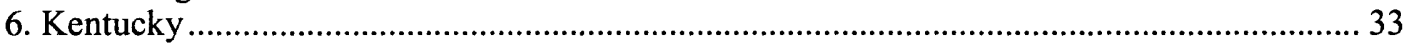

TABLES

1. Adjustment coefficients for drainage basins with 40- to 100-percent area

underlain by carbonate rocks in the western region in Maryland.

2. Coordinates of centers of drainage basins in the southern region, Maryland and Virginia

3. Average standard errors of prediction for regression-based equations for estimating low-flow characteristics in Maryland and Delaware.

4. Range of basin characteristics used in developing regression-based equations for estimating low-flow characteristics in Maryland and Delaware.

5. Streamflow-gaging stations used in regional analyses of low-flow frequencies in Maryland and Delaware.

6. Percentage of basin area underlain by carbonate rocks at gaged basins in carbonate areas of the western region of Maryland

7. Streamflow-gaging-station pairs used in analysis of accuracy of low-flow estimates at ungaged sites on gaged streams

8. Standard deviations and means of residuals from low-flow estimates at ungaged sites on gaged streams in Pennsylvania, New York, Maryland, West Virginia, and Kentucky.

9. Basin characteristics used in equations for estimation of low-flow characteristics of streams in Maryland and Delaware ....

10. Basin characteristics at continuous-record streamflow-gaging stations in Maryland and Delaware

11. Low-flow characteristics at continuous-record streamflow-gaging stations in Maryland and Delaware

12. Basin characteristics and low-flow characteristics at partial-record streamflow-gaging stations in Maryland and Delaware 


\title{
LOW-FLOW CHARACTERISTICS OF STREAMS IN MARYLAND AND DELAWARE
}

\author{
By David H. Carpenter and Donald C. Hayes
}

\begin{abstract}
Hydrologic information on the variability of streamflow during low-flow periods is needed for the effective management of surface-water resources in Maryland and Delaware. Low-flow characteristics derived from streamflow under natural conditions are presented for 94 continuousrecord gaging stations in Maryland, Delaware, and surrounding States, and for 131 low-flow partial-record gaging stations in Maryland and Delaware. Methods are developed to estimate low-flow characteristics at ungaged stream sites for average 7-, 14-, and 30-consecutive-day lowflow discharges for recurrence intervals of 2, 10, and 20 years. The methods are applicable to unregulated streams in Maryland and Delaware for watersheds having drainage areas ranging from 2.0 to 875 square miles.
\end{abstract}

Maryland and Delaware are divided into four regions on the basis of physiography and the results of regression analyses. The regions are the Eastern Shore region in Maryland and Delaware, the eastern-Piedmont region in Maryland, the western region in Maryland, and the southern region in Maryland. Equations are developed from regression analyses to estimate lowflow characteristics at ungaged sites on ungaged streams for the Eastern Shore region, the easternPiedmont region, and the western region. A generalized least-squares multiple-regression technique is used to develop the estimation equations that relate average 7-, 14-, and 30consecutive-day low-flow discharges for recurrence intervals of 2, 10, and 20 years to physical and climatological features of drainage basins in the study area. Adjustments are necessary to low-flow discharges estimated from the equation for the western region because of the effects of carbonate rocks on low flows. The adjustment method is based on analysis of the residuals of regional estimation equations and the percentage of the basin underlain by carbonate rocks. An equation is developed on the basis of a distance-weighted average of low-flow discharges at gaging stations to estimate low flow characteristics at ungaged sites on ungaged streams for the southern region. Estimates of the accuracy of low-flow characteristics determined from all regional equations are provided.

Two methods are presented for estimating low-flow characteristics at ungaged sites on gaged streams. One method combines low-flow characteristics determined from gaging station data with results from the regional regression equation at the gaging station and at the ungaged site to estimate the low-flow characteristics either upstream or downstream from the gaging station. The other method estimates low-flow characteristics at ungaged sites between gaging stations using a graphical solution. Estimates of accuracy of the low-flow characteristics determined by these methods also are provided. 


\section{INTRODUCTION}

Hydrologic information on the amount and variability of streamflow during periods of low flow is essential to effective development and management of water resources. Low-flow data are used in a variety of ways, such as in the design of water-supply and sewage-treatment facilities. Low-flow information is also important to many other concerns, including time-of-travel and dilution of toxic spills, quality and availability of water for irrigation, and streamflow-temperature degradation.

In order to provide the type of information described above, information that will be useful to planners, consulting engineers, government agencies, and others who are responsible for the efficient use and development of the water resources of Maryland and Delaware, the U.S. Geological Survey (USGS), in cooperation with the Maryland Geological Survey and the Maryland Water Resources Administration, and with the partial support of the Delaware Geological Survey and the Delaware Department of Natural Resources and Environmental Control, collected, compiled and analyzed data for low-flow periods on streams in Maryland, Delaware, and surrounding States. This report presents the results of that effort.

\section{Purpose and Scope}

The purpose of this report is to provide information on the magnitude of the sustained flow of rivers and streams in Maryland and Delaware during periods of low flow, and to provide methods for estimation of low-flow characteristics throughout the area. The report provides data on low-flow characteristics for natural streamflow from gaging stations $^{1}$ in the surrounding States. Included in the report are results of regional analyses through which methods were developed for estimating lowflow characteristics at ungaged sites.
Low-flow data are provided from networks of continuous-record and partial-record streamflowgaging stations in Maryland and Delaware and from nearby continuous-record gaging stations in the surrounding States. Data are presented for a total of 94 continuous-record gaging stations and 131 low-flow partial-record gaging stations. The gaging-station data are intended to reflect only natural flows, virtually unaffected by regulation, diversion, or urban development.

The report presents regional equations for estimating low-flow characteristics under natural conditions at ungaged sites in Maryland and Delaware. Estimation equations are developed for four hydrologic regions (pl. 1). The Eastern Shore region covers essentially all the area within the Coastal Plain Province in Maryland and Delaware, east of the Chesapeake Bay. The eastern-Piedmont region covers the area within the Piedmont Province in Maryland, primarily east of the Monocacy River. The eastern-Piedmont region is further subdivided into four subregions, each with separate estimation equations. The western region includes the area within the Piedmont, primarily west of the Monocacy River, Blue Ridge, Valley and Ridge, and Appalachian Plateaus Provinces in Maryland. The southern region covers essentially the area within the Coastal Plain Province in Maryland, west of the Chesapeake Bay.

The report also presents two methods for estimating low-flow characteristics at ungaged sites on gaged streams. One method combines low-flow characteristics determined from gaging-station data with results from applicable regional regression equations at the gaging station and at the ungaged site to estimate the low-flow characteristics either upstream or downstream from the gaging station. The other method estimates low-flow characteristics at ungaged sites between gaging stations using a graphical solution.

This report updates an earlier report (Carpenter, 1983) that presented similar low-flow information, though in a less comprehensive manner. The

1 Words in boldface are found in the Glossary. 
earlier report, which described peak-flow and lowflow characteristics, provided the first methods for estimating low-flow characteristics at ungaged sites in Maryland and was based only on streamflow records from continuous-record gaging stations through March 1979. This report provides more accurate estimation equations for low-flow characteristics at ungaged sites on ungaged streams than the earlier report, with greater areal coverage based on data from substantially more gaging stations and streamflow records through March 1987. Advances in analytical techniques allowed data from partial-record gaging stations to be included in regionalization analyses for this report. Increasing the available data allowed improvements to the western region estimation equations by adjusting the low-flow characteristics for the effects of carbonate rocks on low flows. In addition, this report provides more accurate methods to transfer low-flow characteristics to ungaged sites on gaged streams.

One advanced analytical technique that was investigated for this report is the moment-estimator transfer technique which is used to transfer lowflow characteristics from continuous-record (index) gaging stations to partial-record gaging stations (Stedinger and Thomas, 1985). Another advanced technique, the generalized least-squares (GLS) regression analysis (Tasker, 1989), has been utilized for regional multiple-regression analyses and allows for weighting input station data relative to accuracy and independence.

\section{Physical and Hydrologic Environment}

Maryland and Delaware are two of the smaller states in the Eastern United States, yet they contain a wide variety of physiographic characteristics. Surface- and ground-water supplies are plentiful because of substantial precipitation and a humid climate. Increasing population and industrial growth, however, are stressing the water supplies in certain areas.

\section{Location and Extent}

Maryland lies between $37^{\circ} 53^{\prime}$ and 39 $43^{\prime}$ north latitude and between $75^{\circ} 04^{\prime}$ and $79^{\circ} 29^{\prime}$ 'west longitude. The State has an irregular shape that would fit on a rectangle $240 \mathrm{mi}$ long (east-west) by
$125 \mathrm{mi}$ wide (north-south). The total area of Maryland is $10,577 \mathrm{mi}^{2}$, of which $9,891 \mathrm{mi}^{2}$ is land and $686 \mathrm{mi}^{2}$ is inland water. Chesapeake Bay area is not included in the area described.

Delaware lies on the eastern border of Maryland and extends to the Delaware Bay in the north and the Atlantic Ocean in the south. Delaware lies between $38^{\circ} 27^{\prime}$ and $39^{\circ} 50^{\prime}$ ' north latitude and between $75^{\circ} 05^{\prime}$ and $75^{\circ} 46^{\prime}$ 'west longitude. The total area of Delaware is $2,057 \mathrm{mi}^{2}$, of which $1,982 \mathrm{mi}^{2}$ is land and $75 \mathrm{mi}^{2}$ is inland water.

\section{Physiography}

Five physiographic provinces are represented in Maryland--the Coastal Plain, Piedmont, Blue Ridge, Valley and Ridge, and Appalachian Plateaus. The Coastal Plain is the only physiographic province represented in Delaware. Generalized boundaries of these provinces and subdivisions are shown in figure 1. A brief description of each province is as follows:

Coastal Plain.--The Coastal Plain Province in Maryland consists of two distinct parts: (1) the Eastern Shore, and (2) the western shore east of the Fall Line. The Coastal Plain Province in Delaware consists only of the Eastern Shore. The Eastern Shore is low, flat, and poorly drained by small, sluggish streams. The western shore part is more rolling with slightly less sluggish streams than the Eastern Shore. Most streams and rivers of the Coastal Plain are affected by tides for a considerable distance above their outlets to the Chesapeake Bay, Delaware Bay, or Atlantic Ocean.

Piedmont.--The Piedmont Province is characterized by rolling topography, low hills and ridges, and fairly steep stream slopes. The province is well drained by many streams and rivers that flow into Chesapeake Bay.

Blue Ridge.--The Blue Ridge Province in Maryland consists of the Catoctin and South Mountains. The province has rugged topography and relatively great relief. It is well drained, principally by Catoctin Creek and its tributaries. 


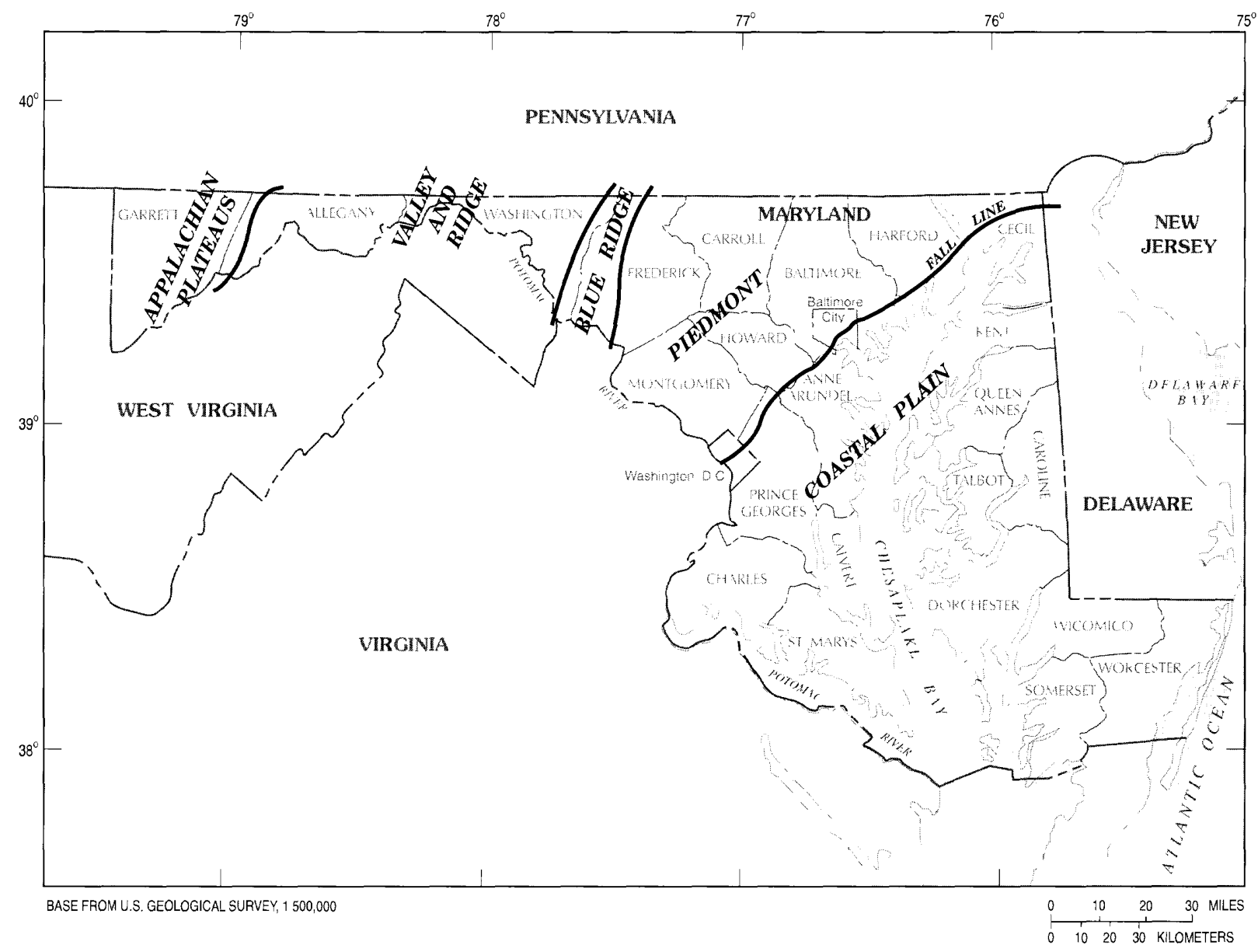

Figure 1. Physiographic provinces of Maryland and Delaware.

Valley and Ridge.--The Valley and Ridge Province is separated in Maryland into the Great Valley and the Allegheny Ridges. The Great Valley is a gently rolling, broad lowland drained by Antietam and Conococheague Creeks. Streams have gentle slopes and meandering courses. Cavernous limestone underlies the valley. Caves, sinkholes, and springs are common and the streams tend to have a more uniform flow than do streams in other areas of the State. The Allegheny Ridges are a series of northeastwardtrending hills west of the Conococheague Creek basin. The Allegheny Ridges have relatively level and uniform ridge lines and are drained by fairly steep, swift streams.

Appalachian Plateaus.--The Appalachian Plateaus Province is a broad dissected upland with pro- nounced relief and rugged topography. Streams draining the Plateaus generally have steep gradients, rapids, and waterfalls. Streams in Maryland that drain into the Ohio River basin are all in this province.

\section{Climate}

Maryland has hot summers and mild winters. The seasons are well defined and precipitation usually falls fairly frequently throughout the year. Average annual precipitation for the State ranges from about 36 to $52 \mathrm{in} / \mathrm{yr}$ (fig. 2). Precipitation is affected by the orographic effect of the mountains in the western part of the State. Moisture tends to precipitate from air masses that are cooled as they ascend the western slopes of the mountains. As a result, one of the areas of greatest annual 


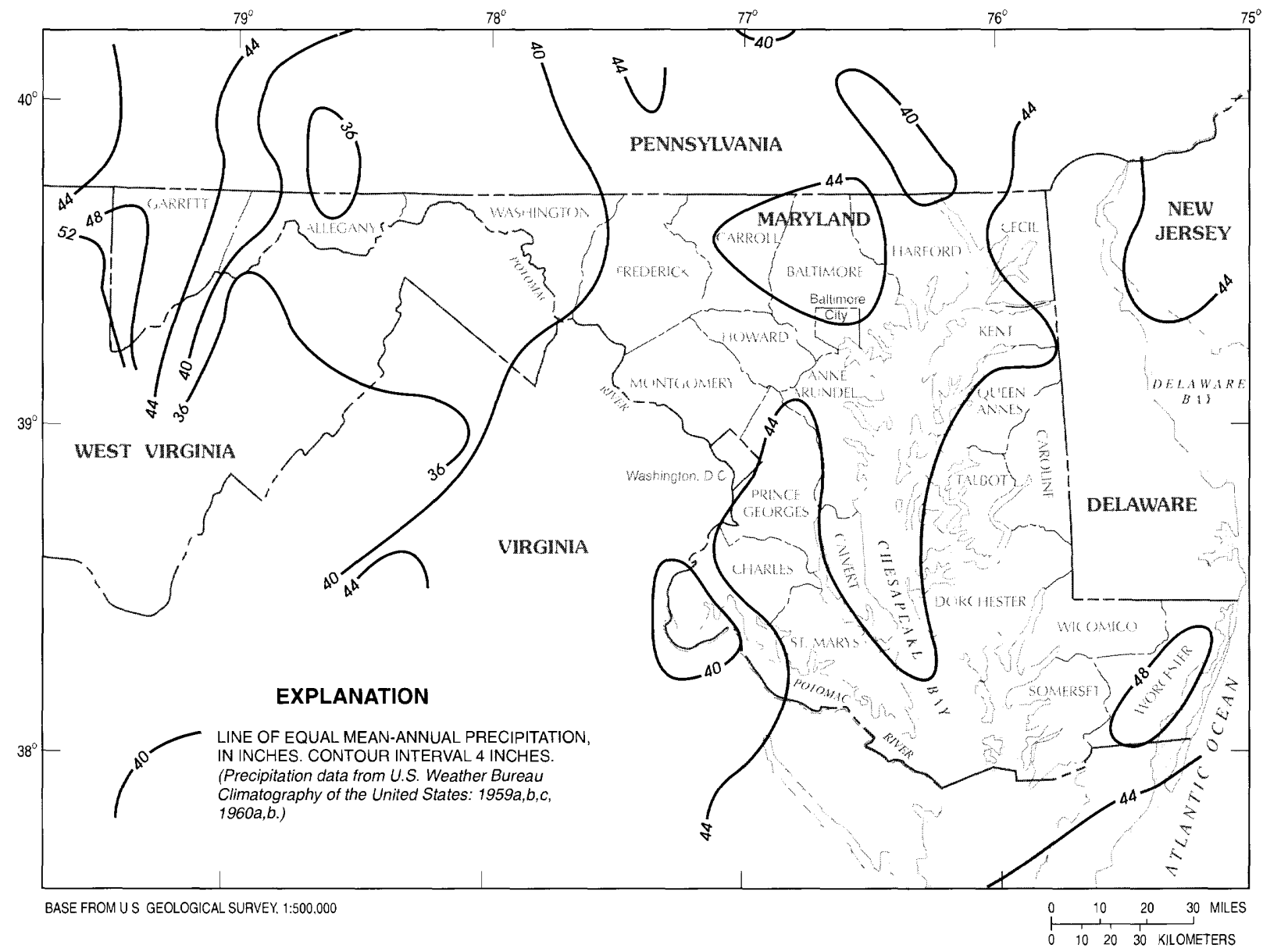

Figure 2. Mean annual precipitation in Maryland, Delaware, and adjacent States.

precipitation, over 48 in., is in the extreme western part of the State. As this moisture-depleted air moves eastward, a rain shadow is formed and the least annual precipitation (less than 36 in.) falls in the Cumberland area, only some $50 \mathrm{mi}$ from the wettest area. Another area of high precipitation is near the ocean on the southern Eastern Shore. The geography, physiography, and climate of Maryland are described in more detail by Vokes and Edwards (1974).

The climate in Delaware is the same as the climate in eastern Maryland. Average annual precipitation for the State is approximately $44 \mathrm{in} / \mathrm{yr}$ (fig. 2). Annual precipitation is $44 \mathrm{in} / \mathrm{yr}$ in northern Delaware and increases slightly to the south.
Usually, more precipitation falls in both States during the summer months than during the other months of the year. During the summer, however, precipitation usually comes from thunderstorms, and thus the amount of moisture is less dependable and more variable than from winter storms.

Because of the variability in the amount of precipitation and because of increased evapotranspiration, the summer generally is the time of lowest streamflows.

\section{LOW-FLOW-FREQUENCY CONCEPTS AND TERMINOLOGY}

Hydrologic information on the amount and variability of streamflow during low-flow periods is essential to effective management of water resources. Valuable insight into the variability of 
low streamflow can be provided by low-flow characteristics which are easily understood indices of the magnitude and frequency of low flows.

Low-flow characteristics, as defined in this report, are minimum average-streamflow rates over designated time periods. The average discharges are anticipated to be less than these flow rates with specified frequencies. For example, a 7-day, 10year low flow at a site of $20 \mathrm{ft}^{3} / \mathrm{s}$ means a discharge of less than $20 \mathrm{ft}^{3} / \mathrm{s}$ (average over the lowest 7-consecutive days in the year) should be expected at that site once every 10 years, on the average. Similarly, a 20-year low flow of $5 \mathrm{ft}^{3} / \mathrm{s}$ means that a discharge of less than $5 \mathrm{ft}^{3} / \mathrm{s}$ will be the annual minimum, on the average, 1 time in 20 years, 2 times in 40 years, and 5 times in 100 years. The most widely used discharge value for water-quality management issues is the 7-day, 10-year low flow which represents an uncommon but not extremely rare event.

"Frequency" and "recurrence interval" are terms often used interchangeably in referring to extremes of streamflow such as those mentioned above. "Frequency" is a general term in this report, usually designating how often flow will be less than a given extreme (nonexceeded) in severity during a given period of time. Because the terminology is often widely understood and accepted, the frequencies of flow characteristics are often expressed in terms of recurrence intervals. A "recurrence interval" is defined as the average interval of years during which a given streamflow will be less than a given value once. It is inversely related to the probability of the streamflow being less than a given value in any given year.

Expressing the frequency of extremes in terms of probability is an easier concept to understand. The concept of a 10-percent chance of streamflow less than a given value in any given year is simpler to understand, than grasping the true meaning of a 10-year low flow. Recurrence intervals can be easily transformed into probabilities of nonexceedance by taking the reciprocal of the recurrence interval.
The climatic year is the base-time period used in this report for the analysis of low flows. A climatic year is a 12-month period from April 1 through March 31. For example, the 12-month period ending March 31, 1991, is the 1990 climatic year.

\section{LOW-FLOW CHARACTERISTICS AT GAGING STATIONS}

Low-flow characteristics for 225 gaging stations are presented in this report. Tabulated data for 94 continuous-record gaging stations and 131 low-flow partial-record gaging stations are listed in tables 11 and 12, respectively, found at the end of the report. The following low-flow characteristics are presented for the continuous-record and partialrecord gaging stations: 7-, 14-, and 30-day, 2-, 10-, and 20-year discharges. The locations of the 225 gaging stations are shown on plate 1 .

Data collected at a continuous-record gaging station provide a continuous record of the water stage used to calculate the flow in a stream. For these gaging stations, discharge data are available from stage data on a continuous basis, whereas, at partial-record gaging stations, only intermittent data are available. At low-flow partial-record gaging stations, measurements of discharge are made periodically during times of base flow. These point (in time) discharge values are correlated with the concurrent daily flows at nearby continuousrecord gaging stations to develop relations from which to determine low-flow characteristics.

Unless otherwise noted, all discharge data presented in this report represent flow believed to be essentially unregulated and unaffected by diversions. The effects of regulation and minor diversions on low flows, however, are sometimes difficult to identify. The use of the average 7-day flow, which is usually the shortest period for which low-flow characteristics are published, minimizes the effects of minor regulation. The 7-day period is the length of a normal workweek and, when a mill or small hydroelectric plant is the source of regulation, the amounts of water stored and released during a week often balance out. On any particular day, however, flow may be severely regulated. 
At several gaging stations in the study area, there have been periods of both regulated and natural flow. At these gaging stations, the records have been separated into regulated and unregulated periods. Only the unregulated periods have been used to define the low-flow characteristics presented.

In the tables of low-flow and basin characteristics, a dash entered in a space, rather than a value, indicates the value was not determined. Discharge values are shown to the nearest tenth of a cubic foot per second for discharges between 1.0 and $10 \mathrm{ft}^{3} / \mathrm{s}$, and to whole numbers between 10 and $1,000 \mathrm{ft}^{3} / \mathrm{s}$. Discharges less than $1.0 \mathrm{ft}^{3} / \mathrm{s}$ are shown to one significant figure. Discharges between 0 and $0.05 \mathrm{ft}^{3} / \mathrm{s}$ are shown to indicate the theoretical probability of nonzero flow, though zero for practical purposes.

\section{Continuous-Record Gaging Stations}

At continuous-record gaging stations, lowflow characteristics were determined from lowflow-frequency curves developed by fitting the Pearson Type III distribution to the logarithms of annual low-flow data. Visual comparisons were made between fitted curves and plotted flow data (based on Weibull plotting positions), and where there was no reasonable agreement, the final curves were fitted manually. Because of the subjectivity of curve fitting, low-flow-frequency values (lowflow characteristics) should not be extrapolated to recurrence intervals much beyond the 20 -year values given in tables 11 and 12 . For continuousrecord gaging stations, low-flow characteristics are provided only for those stations with at least 10 years of record.

\section{Partial-Record Gaging Stations}

At low-flow partial-record gaging stations and at short-term continuous-record gaging stations (less than 10 years of record), low-flow characteristics are based on correlations with nearby longterm continuous-record (index) gaging stations. At partial-record and short-term continuous-record gaging stations (considered low-flow partial-record gaging stations in this report), periodic observations of discharge during periods of base flow were plotted with concurrent observations of daily flow at the nearby index stations where low-flow char- acteristics already had been determined as described in the previous section. Relations were then determined by linear regression, with logarithms of the concurrent discharges used as the data points.

Graphical representations of the regression relations were inspected for goodness of fit. If the fits appeared reasonable, estimates of mean and variance of the logarithms of the annual 7-, 14-, and 30-day low flows at the partial-record stations were made on the basis of the regression relations. Estimates of low-flow characteristics at the 131 partial-record stations were then determined on the basis of the estimates of mean and variance at those stations and the assumptions that the logarithms of low flows are Pearson Type III distributions. The above estimates were made using the statistical moment-estimator transfer technique of Stedinger and Thomas (1985) using an equation to relate the T-year low flow to estimates of mean and variance: $T$-year low flow $=$ mean + $\mathrm{K}$ (variance) ${ }^{0.5}$, where $\mathrm{T}$ is the recurrence interval and $\mathrm{K}$ is the Pearson Type III frequency factor, a function of skew and recurrence interval. This transfer technique was developed to avoid bias inherent in a previously used technique that utilized the linear-regression relations to transfer lowflow characteristic values directly from the index stations to the partial-record gaging stations.

The relative reliability of the low-flow characteristics presented for the partial-record gaging stations in table 12 are: (1) the number of concurrent discharge measurements used, (2) the period of time measurements were made, (3) the equivalent years of record, (4) the length of record of the long-term index stations with which the stations were correlated, (5) the coefficients of determination $\left(R^{2}\right)$ and standard errors of estimate of the linear regressions, and $(6)$ the minimum discharges observed at the low-flow stations and used in the correlations.

\section{Accuracy and Limitations}

The accuracy of low-flow characteristics at gaging stations is related to the lengths of records upon which the characteristics are based and also the at-site variance and skew of the annual lowflow discharges. Low-flow data based on one 
10-year period may differ significantly from data based on another 10-year period. Also, data based on a 10-year period may differ significantly from data based on 20 or 40 years of record. A long period of dry or wet years will significantly affect the low-flow characteristics based on short records and may even have significant effect on low-flow characteristics based on long records.

Low-flow characteristic values should not be extrapolated to recurrence intervals beyond the 20year values shown in tables 11 and 12 for the reasons given above. Extrapolation is not recommended also because low-flow frequency curves may be distorted at the low-discharge (high-recurrence interval) end from undetected regulation and because the data points defining base-flow frequency curves sometimes come from more than one population (Riggs, 1972).

\section{LOW-FLOW CHARACTERISTICS AT UNGAGED LOCATIONS}

Regardless of how extensive a network of streamflow-gaging stations in a region is, streamflow information frequently is needed at sites where no data have been collected. At such sites, low-flow characteristics may be estimated by one of several methods; for ungaged sites on ungaged streams, regionalized estimation equations or a distance-weighted average of low-flow characteristics from gaging stations is used, and for ungaged sites on gaged streams, transfer of low-flow characteristics from the gaging stations is used.

The following methods are presented for estimating low-flow characteristics for natural drainage basins without urban development or regulated flow, and apply to 7-, 14-, and 30-consecutive-day low-flow periods with recurrence intervals of 2,10 , and 20 years. The methods were developed from daily flow records from 93 continuous-record gaging stations in Maryland and Delaware, and in nearby Pennsylvania, West Virginia, and Virginia. Also included were low-flow data from 131 partial-record gaging stations in Maryland and Delaware. These methods will provide estimates of low-flow characteristics for the various situations that may be encountered. Step-by-step examples of different types of computations are provided in the section "Estimation Examples."

\section{Ungaged Streams}

Estimation equations, or mathematical models, were developed by multiple-regression analyses of essentially all the gaging-station data, reflecting natural conditions, available within the study area. Data on the physical properties of the drainage basins upstream from the ungaged sites serve as the input to the estimation equations. Detailed descriptions of multiple-regression techniques are provided in many textbooks on statistics such as Chatterjee and Price (1977). Streamflow applications of regression techniques are discussed in Riggs (1973). A generalized least-squares multiple-regression technique (Tasker and Stedinger, 1989) was used to develop most of the estimation equations. The GLS regression weights gagingstation data according to at-site accuracy and independence from nearby sites. For this reason, GLS regression is superior to ordinary least-squares regression that gives data from each gaging station equal weight. The resulting estimation equations were calibrated for drainage areas that range from 2.0 to $875 \mathrm{mi}^{2}$.

The study area was divided into four regions, with one region further subdivided into four subregions, as shown on plate 1 . Regression equations based on the GLS multiple-regression technique were developed for three regions (the Eastern Shore, eastern-Piedmont, and western regions) by determining the relations between low-flow characteristics and basin characteristics, such as drainage area and percentage of forest cover for the gaged basins. Regression equations were developed in the western region for areas underlain by noncarbonate rocks. Adjustments are necessary to the western region equations if any of the basin is underlain by carbonate rocks. No significant regression relations could be determined for the "Bynum anomaly" of the eastern-Piedmont region for which a proration of average low-flow values by drainage area method was developed, or for the southern region for which a distance-weighted average of low-flow characteristics from gaging stations method was developed. 
Six sets of relations, which are applicable to the Eastern Shore, eastern-Piedmont, and western regions, were determined by GLS multiple-regression analyses. The relations were quantified in mathematical models of the form

$$
{ }_{N} Q_{T}=K \times A^{a} \times B^{b} \times C^{c} \ldots I^{i}
$$

where

$$
\begin{gathered}
\mathrm{NQ}_{\mathrm{T}}=\text { low-flow characteristic (where } \mathrm{N} \text { is } \\
\text { the number of consecutive days } \\
\text { with recurrence interval of } \mathrm{T} \text { years); } \\
\mathrm{K}=\text { the constant of the equation; }
\end{gathered}
$$

$$
\mathrm{A}, \mathrm{B}, \mathrm{C}, \ldots . . \mathrm{I}=\text { related basin characteristics; and }
$$

$\mathrm{a}, \mathrm{b}, \mathrm{c}, \ldots ., \mathrm{i}=$ exponents applied to the basin characteristics.

These regression equations were developed in logarithmic-linear form and then converted to exponential form. The equations can be applied to estimate low flows at ungaged drainage basins and reliability can be determined to a large extent from the related average standard errors of prediction. Standard errors of prediction are given and their implications are discussed in the section "Accuracy and Limitations."

The basin characteristics may be determined from topographic maps, and from the precipitation map (fig. 2) and soils maps (pls. 2-10). Detailed definitions of basin characteristics and explanations are provided in the section "Estimation Examples." Basin characteristics expressed in percentages $\left(F, S_{a}\right.$, and $\left.S_{d}\right)$ have a constant of 10.0 added before being raised to the appropriate exponents. If the value of one of these basin characteristics is zero, the constant 10.0 still must be included in the equation, evaluated as 10 to the appropriate exponent. Constants were added to the discharges (dependent variables) in some of the low-flow regression models to be able to work in logarithmic space when values go to zero (explained in the section "Regression Analyses").

\section{Sites in Eastern Shore and Eastern-Piedmont Regions}

Low-flow estimates may be made by applying the following equations for ungaged sites in the Eastern Shore region and for ungaged sites in the subregions of the eastern-Piedmont region, except in the Bynum anomaly. The number of gaging stations used in developing the models are given for each region or subregion.

$$
\begin{gathered}
\begin{array}{c}
\text { Eastern Shore Region } \\
\text { [54-station model] }
\end{array} \\
7 \mathrm{Q}_{2}+0.2=0.396 \mathrm{~A}^{0.916}(\mathrm{~F}+10)^{-0.433}\left(\mathrm{~S}_{\mathrm{a}}+10\right)^{0.559}\left(\mathrm{~S}_{\mathrm{d}}+10\right)^{-0.556}(1) \\
7 \mathrm{Q}_{10}+0.2=0.269 \mathrm{~A}^{0.887}(\mathrm{~F}+10)^{-0.375}\left(\mathrm{~S}_{\mathrm{a}}+10\right)^{0.522}\left(\mathrm{~S}_{\mathrm{d}}+10\right)^{-0.640} \\
7 \mathrm{Q}_{20}+0.2=0.204 \mathrm{~A}^{0.876}(\mathrm{~F}+10)^{-0.346}\left(\mathrm{~S}_{\mathrm{a}}+10\right)^{0.494}\left(\mathrm{~S}_{\mathrm{d}}+10\right)^{-0.646} \\
14 \mathrm{Q}_{20}+0.2=0.417 \mathrm{~A}^{0.924}(\mathrm{~F}+10)^{-0.413}\left(\mathrm{~S}_{\mathrm{a}}+10\right)^{0.537}\left(\mathrm{~S}_{\mathrm{d}}+10\right)^{-0.554} \\
14 \mathrm{Q}_{10}+0.2=0.278 \mathrm{~A}^{0.894}(\mathrm{~F}+10)^{-0.366}\left(\mathrm{~S}_{\mathrm{a}}+10\right)^{0.496}\left(\mathrm{~S}_{\mathrm{d}}+10\right)^{-0.618} \\
14 \mathrm{Q}_{20}+0.2=0.221 \mathrm{~A}^{0.881}(\mathrm{~F}+10)^{-0.334}\left(\mathrm{~S}_{\mathrm{a}}+10\right)^{0.474}\left(\mathrm{~S}_{\mathrm{d}}+10\right)^{-0.634} \\
30 \mathrm{Q}_{20}+0.2=0.426 \mathrm{~A}^{0.925}(\mathrm{~F}+10)^{-0.384}\left(\mathrm{~S}_{\mathrm{a}}+10\right)^{0.506}\left(\mathrm{~S}_{\mathrm{d}}+10\right)^{-0.538} \\
30 \mathrm{Q}_{10}+0.2=0.288 \mathrm{~A}^{0.897}(\mathrm{~F}+10)^{-0.364}\left(\mathrm{~S}_{\mathrm{a}}+10\right)^{0.495}\left(\mathrm{~S}_{\mathrm{d}}+10\right)^{-0.60} \\
30 \mathrm{Q}_{20}+0.2=0.221 \mathrm{~A}^{0.888}(\mathrm{~F}+10)^{-0.354}\left(\mathrm{~S}_{\mathrm{a}}+10\right)^{0.491}\left(\mathrm{~S}_{\mathrm{d}}+10\right)^{-0.61}
\end{gathered}
$$

\section{Eastern-Piedmont Region Subregion $A$ [12-station model]}

$$
\begin{aligned}
7 Q_{20} & =0.201 \mathrm{~A}^{1.000} \\
7 \mathrm{Q}_{10} & =0.0579 \mathrm{~A}^{1.076} \\
7 \mathrm{Q}_{20} & =0.0357 \mathrm{~A}^{1.103} \\
14 \mathrm{Q}_{20} & =0.235 \mathrm{~A}^{0.983} \\
14 \mathrm{Q}_{10} & =0.0684 \mathrm{~A}^{1.057} \\
14 \mathrm{Q}_{20} & =0.0446 \mathrm{~A}^{1.077} \\
30 \mathrm{Q}_{20} & =0.273 \mathrm{~A}^{0.991} \\
30 \mathrm{Q}_{10} & =0.0885 \mathrm{~A}^{1.051} \\
30 \mathrm{Q}_{20} & =0.0655 \mathrm{~A}^{1.056}
\end{aligned}
$$

Eastern-Piedmont Region Subregion $B$ [22-station model]

$$
\begin{aligned}
7 Q_{20} & =0.329 A^{0.955} \\
7 Q_{10} & =0.136 A^{0.956} \\
7 Q_{20} & =0.0966 A^{0.962}
\end{aligned}
$$




$$
\begin{aligned}
& 14 Q_{20}=0.337 A^{0.962} \\
& 14 Q_{10}=0.149 A^{0.964} \\
& 14 Q_{20}=0.113 A^{0.962} \\
& 30 Q_{20}=0.353 A^{0.973} \\
& 30 Q_{10}=0.178 A^{0.964} \\
& 30 Q_{20}=0.145 A^{0.955}
\end{aligned}
$$

Eastern-Piedmont Region Subregion $C$ [23-station model]

$$
\begin{aligned}
7 Q_{20} & =0.371 A^{1.048} \\
7 Q_{10} & =0.164 A^{1.092} \\
7 Q_{20} & =0.117 A^{1.128} \\
14 Q_{20} & =0.405 A^{1.037} \\
14 Q_{10} & =0.190 A^{1.069} \\
14 Q_{20} & =0.142 A^{1.092} \\
30 Q_{20} & =0.441 A^{1.031} \\
30 Q_{10} & =0.220 A^{1.060} \\
30 Q_{20} & =0.170 A^{1.081}
\end{aligned}
$$

\section{Eastern-Piedmont Region Subregion D [15-station model]}

$$
\begin{aligned}
7 Q_{20} & =0.186 A^{1.160} \\
7 Q_{10} & =0.0720 A^{1.233} \\
7 Q_{20} & =0.0526 A^{1.256} \\
14 Q_{20} & =0.216 A^{1.143} \\
14 Q_{10} & =0.0836 A^{1.215} \\
14 Q_{20} & =0.0597 \mathrm{~A}^{1.243} \\
30 Q_{2} & =0.282 \mathrm{~A}^{1.106} \\
30 Q_{10} & =0.109 \mathrm{~A}^{1.180} \\
30 Q_{20} & =0.0807 \mathrm{~A}^{1.202}
\end{aligned}
$$

where

$7 \mathrm{Q}_{2}, 7 \mathrm{Q}_{10}, . ., 30 \mathrm{Q}_{20}$ are the low-flow discharges for 7 days, 7 days,..., 30 days, with recurrence intervals of 2 years, 10 years, ...., 20 years;
$A$ is the drainage area, in square miles:

$F$ is the forest cover, in percent;

$S_{a}$ is the type A soils, in percent;

$S_{d}$ is the type D soils, in percent.

In one small area of subregion $C$ of the eastern-Piedmont region, designated the "Bynum anomaly" (see pl. 1), none of the regional estimation equations apply. Estimates of low-flow characteristics for drainage basins located in this anomalous area may be made by first determining a low-flow characteristic, the average (in cubic feet per second per square mile) of the flow from the three gaging stations in the area (tables 11 and 12). The average value may then be multiplied by the size of the drainage area at the selected site. The resulting discharge may be considered a fairly reasonable estimate of the low-flow characteristic under consideration. However, since the reason for the disparity between low flows inside and outside of the Bynum anomaly is unknown, estimated low flows should be used with caution.

\section{Sites in Western Region}

Low-flow estimates may be made by applying the following equations for ungaged sites in the western region for areas underlain by noncarbonate rocks. Adjustments to the calculations are necessary if any of the basin is underlain by carbonate rocks.

\section{Western Region [65-station model]}

$$
\begin{aligned}
& 7 Q_{20}+0.05=12.4 A^{1.038}(60-P)^{-1.980} \\
& 7 Q_{10}+0.05=4.41 A^{0.926}(60-P)^{-1.785} \\
& 7 Q_{20}+0.05=2.94 A^{0.890}(60-P)^{-1.689}
\end{aligned}
$$

$$
14 Q_{20}+0.05=13.3 \mathrm{~A}^{1.061}(60-P)^{-1.973}
$$

$14 Q_{10}+0.05=4.85 A^{0.954}(60-P)^{-1.801}$

$14 Q_{20}+0.05=3.27 A^{0.909}(60-P)^{-1.695}$

$30 \mathrm{Q}_{20}+0.05=18.4 \mathrm{~A}^{1.087}(60-\mathrm{P})^{-2030}$

$30 \mathrm{Q}_{10}+0.05=7.38 \mathrm{~A}^{0.994}(60-\mathrm{P})^{-1.902}$

$30 \mathrm{Q}_{20}+0.05=5.03 \mathrm{~A}^{0956}(60-\mathrm{P})^{-1.804}$ 
where

$7 \mathrm{Q}_{2}, 7 \mathrm{Q}_{10}, . ., 30 \mathrm{Q}_{20}$ are the low-flow discharges for 7 days, 7 days,...., 30 days, with recurrence intervals of 2 years, 10 years,...., 20 years;

$\mathrm{A}$ is the drainage area, in square miles; and

$\mathrm{P}$ is the mean-annual precipitation, in inches.

Adjusted low-flow estimates may be made by the following method for drainage basins in the western region underlain by carbonate rocks, found in Washington and Frederick Counties. First, a preliminary estimate of the low-flow characteristic at the selected site should be made by using the western region equations (eqs. 46-54) for areas underlain by noncarbonate rocks. Next, the percentage of the drainage basin underlain by carbonate rocks is determined. An outline of the drainage basin could be superimposed on a map upon which the carbonate rocks have been delineated [see Duigon and Dine (1991) for sites in Washington County, or Duigon and Dine (1987) for sites in Frederick County]. Areas underlain by carbonate rocks within the drainage-basin boundary are then measured and the area determined, in percent. If the area underlain by carbonate rocks is between 40 and 100 percent, an adjustment coefficient from table 1 should be applied directly to the discharge computed from the western region equations for areas underlain by noncarbonate rocks. For a site where less than 40 percent of the basin is underlain by carbonate rocks, the adjusted low-flow estimate is made by interpolation by modifying the adjustment coefficient (table 2) to be applied to the discharge computed from the western region estimation equations for areas underlain by noncarbonate rocks. The modified adjustment coefficient is determined by straight-line arithmetic interpolation from 0 -percent area underlain by carbonate rocks value (where the modified adjustment-coefficient value is 1.0 ) to 40 -percent area underlain by carbonate rocks value (where the modified adjustment-coefficient value equals the table 1 adjustment-coefficient value) for the given low-flow characteristic. For example, the modified adjust- ment-coefficient value for the $7 \mathrm{Q}_{2}$ discharge from a basin with 20 -percent area underlain by carbonate rocks value would be

$$
(7.20-1.0)\left(\frac{20}{40}\right)+1.0=4.10 .
$$

Carbonate rocks designated "Grove Limestone," "Frederick Limestone," and "Tomstown Dolomite" were used in Frederick County, and an area designated "Area underlain by limestone or dolomite" was used in Washington County for this study.

Table 1. Adjustment coefficients for drainage basins with 40- to 100-percent area underlain by carbonate rocks in the western region in Maryland

\begin{tabular}{lcl}
\hline $\begin{array}{l}\text { Adjusted } \\
\text { low-flow } \\
\text { characteristic }\end{array}$ & $\begin{array}{l}\text { Adjustment } \\
\text { coefficient }\end{array}$ & $\begin{array}{l}\text { Standard } \\
\text { deviation } \\
\text { (percent) }\end{array}$ \\
\hline $7 Q_{2}$ & 7.20 & $69(-47,91)$ \\
$7 Q_{10}$ & 10.2 & $75(-50,100)$ \\
$7 Q_{20}$ & 11.2 & $78(-51,105)$ \\
$14 Q_{2}$ & 6.42 & $67(-47,88)$ \\
$14 Q_{10}$ & 9.12 & $72(-49,96)$ \\
$14 Q_{20}$ & 9.84 & $74(-50,99)$ \\
$30 Q_{2}$ & & $64(-45,83)$ \\
$30 Q_{10}$ & 5.39 & $70(-48,93)$ \\
$30 Q_{20}$ & 7.58 & $73(-49,97)$ \\
\hline
\end{tabular}

${ }^{1}$ Coefficients apply to area underlain by carbonate rocks values of 40 to 100 percent. Coefficients are as shown for 40 -percent area underlain by carbonate rocks value. Coefficient is 1.0 for 0 -percent area underlain by carbonate rocks value. To obtain coefficients between 0 and 40 percent, linearly interpolate between values.

\footnotetext{
2 Standard deviation values are averages of the positive and negative percentage differences from the mean (adjustment coefficient). Since average values are large (greater than 50 percent), positive and negative differences are given separately, in parentheses, for clarification.
} 


\section{Sites in Southern Region}

In the southern region, no significant relation could be identified between any basin characteristic and the low flows. Another estimation method was developed using 17 gaging stations in the region, where low-flow characteristics are estimated using an inverse distance weighting of data available at gaging stations. This method was considered to provide the most practical approach and the most likely to yield reasonable results. Lowflow estimates for ungaged sites in the southern region may be made by the following equation:

$$
\mathrm{Q}_{\mathrm{u}}=\mathrm{A}_{\mathrm{u}}\left[\frac{\frac{\mathrm{Q}_{1} / \mathrm{A}_{1}}{\mathrm{D}_{1}}+\frac{\mathrm{Q}_{2} / \mathrm{A}_{2}}{\mathrm{D}_{2}}+\cdots+\frac{\mathrm{Q}_{\mathrm{n}} / \mathrm{A}_{\mathrm{n}}}{\mathrm{D}_{\mathrm{n}}}}{\frac{1}{\mathrm{D}_{1}}+\frac{1}{\mathrm{D}_{2}}+\cdots+\frac{1}{\mathrm{D}_{\mathrm{n}}}}\right]
$$

where

$Q_{u}$ is the estimated ${ }_{N} Q_{T}$ low-flow characteristic at the selected ungaged site, in cubic feet per second;

$A_{u}$ is the drainage area at the selected ungaged site, in square miles;

$Q_{1}, Q_{2}, . ., Q_{n}$ are the ${ }_{N} Q_{T}$ low-flow characteristics for adjacent basins determined from gaging-station data at gaging stations $1,2, \ldots, \mathrm{n}$, in cubic feet per second;

$A_{1}, A_{2}, . ., A_{n}$ are the drainage areas at adjacent gaging stations $1,2, \ldots, \mathrm{n}$, in square miles;

$D_{1}, D_{2}, \ldots, D_{n}$ are the distances from centers of drainage basins of adjacent gaging stations (in the southern region) $1,2, \ldots, \mathrm{n}$, to center of the selected ungaged drainage basin, in miles; and

where

${ }_{\mathrm{NQ}} \mathrm{Q}_{\mathrm{T}}$ is the low-flow characteristic (for $\mathrm{N}$ consecutive days, with recurrence interval of $T$ years), in cubic feet per second.
The above equation entails transferring lowflow unit-discharge (discharge divided by drainage area) values from adjacent gaging stations inversely weighted by the distance from the selected site. The average of the transferred values is then multiplied by the drainage area at this site resulting in the estimated low-flow value. The drainage areas and at-site $\mathrm{NQ}_{\mathrm{T}}$ values for the gaging stations may be determined from tables 10,11 , and 12 .

From two to four of the index gaging stations should be used with the estimation equation. The angle between the centers of the drainage basins of any two index gaging stations (as measured from the selected site) should exceed approximately 30 degrees before both index stations are used in the equation. Coordinates of the centers of the drainage basins for the index stations are given in table 2 and can be plotted on topographic maps along with the center of the selected drainage basin in order to measure center to center distances. Qualifications and limitations are discussed in the section "Accuracy and Limitations."

\section{Ungaged Sites on Gaged Streams}

The best estimate of low-flow characteristics at an ungaged site on a gaged stream, upstream or downstream from the gaging station, should result from combining low-flow characteristics determined from gaging-station data, low-flow characteristics computed from estimation equations, and the ratio of drainage areas. Low-flow estimates can be made by the following equations for ungaged sites on streams for which gaging-station information is available at another site:

for $R_{A}<1.0$

$$
\mathrm{Q}_{\mathrm{f}}=\mathrm{Q}_{\mathrm{u}}\left[\frac{\mathrm{Q}_{\mathrm{o}}}{\mathrm{Q}_{\mathrm{e}}}\right]
$$

for $1.0 \leq \mathrm{R}_{\mathrm{A}} \leq 2.0$

$$
\mathrm{Q}_{\mathrm{f}}=\mathrm{Q}_{\mathrm{u}}+\mathrm{R}_{\mathrm{A}}\left(\Delta \mathrm{Q}_{\mathrm{g}}\right)\left(1.25-0.25 \mathrm{R}_{\mathrm{A}}\right)
$$

for $\mathrm{R}_{\mathrm{A}}>2.0$

$$
\mathrm{Q}_{\mathrm{f}}=\mathrm{Q}_{\mathrm{u}}+1.5\left(\Delta \mathrm{Q}_{\mathrm{g}}\right)
$$


Table 2. Coordinates of centers of drainage basins in the southern region, Maryland and Virginia

[All stations are in Maryland, except two, which are in Virginia. Latitudes and longitudes are given in degrees ( ${ }^{\circ}$ ), minutes ("), and seconds ("). For locations, see plate 1]

Station Latitude Longitude
no.

\begin{tabular}{lll}
\hline Continuous-Record Gaging Stations & \\
01590000 & $39^{\circ} 00^{\prime} 14^{\prime \prime}$ & $76^{\circ} 39^{\prime} 14^{\prime \prime}$ \\
01594500 & $38^{\circ} 56^{\prime} 19^{\prime \prime}$ & $76^{\circ} 49^{\prime} 09^{\prime \prime}$ \\
01594600 & $38^{\circ} 38^{\prime} 24^{\prime \prime}$ & $76^{\circ} 37^{\prime} 06^{\prime \prime}$ \\
01594800 & $38^{\circ} 28^{\prime} 09^{\prime \prime}$ & $76^{\circ} 31^{\prime} 32^{\prime \prime}$ \\
01653600 & $38^{\circ} 44^{\prime} 04^{\prime \prime}$ & $76^{\circ} 53^{\prime} 21^{\prime \prime}$ \\
01658000 & $38^{\circ} 39^{\prime} 09^{\prime \prime}$ & $76^{\circ} 56^{\prime} 58^{\prime \prime}$ \\
01661000 & $38^{\circ} 25^{\prime} 46^{\prime \prime}$ & $76^{\circ} 46^{\prime} 33^{\prime \prime}$ \\
01661050 & $38^{\circ} 22^{\prime} 53^{\prime \prime}$ & $76^{\circ} 42^{\prime} 54^{\prime \prime}$ \\
01661500 & $38^{\circ} 16^{\prime} 33^{\prime \prime}$ & $76^{\circ} 32^{\prime} 32^{\prime \prime}$ \\
$01661800^{a}$ & $37^{\circ} 52^{\prime} 05^{\prime \prime}$ & $76^{\circ} 31^{\prime} 25^{\prime \prime}$ \\
$01668500^{a}$ & $38^{\circ} 06^{\prime} 07^{\prime \prime}$ & $76^{\circ} 51^{\prime} 34^{\prime \prime}$
\end{tabular}

\section{Partial-Record Gaging Stations}

$\begin{array}{lll}01589090 & 39^{\circ} 09^{\circ} 50^{\prime \prime} & 76^{\circ} 42^{\prime} 19^{\prime \prime} \\ 01589500 & 39^{\circ} 09^{\prime} 15^{\prime \prime} & 76^{\circ} 39^{\prime} 37^{\prime \prime} \\ 01589800 & 39^{\circ} 06^{\prime} 18^{\prime \prime} & 76^{\circ} 40^{\prime} 39^{\prime \prime} \\ 01594455 & 38^{\circ} 53^{\prime} 30^{\prime \prime} & 76^{\circ} 37^{\prime} 27^{\prime \prime} \\ 01660740 & 38^{\circ} 34^{\prime} 53^{\prime \prime} & 76^{\circ} 59^{\prime} 28^{\prime \prime} \\ 01660905 & 38^{\circ} 38^{\prime} 32^{\prime \prime} & 76^{\circ} 48^{\prime} 40^{\prime \prime}\end{array}$

${ }^{a}$ Gaging station located in Virginia.

where

$$
\begin{aligned}
R_{A} & =\frac{A_{u}}{A_{g}} \\
\Delta Q_{g} & =Q_{o}-Q_{e}
\end{aligned}
$$

where

$R_{A}$ is the ratio of drainage area at the selected ungaged site to drainage area at gaging station on same stream;

$\mathrm{Q}_{\mathrm{f}}$ is the final weighted estimate of discharge at the selected ungaged site on the gaged stream;

$\mathrm{Q}_{u}$ is the discharge at the selected ungaged site determined by regionalized estimation equation (eqs. 1-55);
$\mathrm{Q}_{0}$ is the discharge at gaging station determined from gaging-station data (table 11 or 12 );

$\mathrm{Q}_{\mathrm{e}}$ is the discharge at gaging station determined by regionalized estimation equation (eqs. 1-55);

$\Delta \mathrm{Q}_{\mathrm{g}}$ is the discharge at gaging station determined from gaging-station data, minus discharge at gaging station determined by regionalized estimation equation;

$A_{u}$ is the drainage area at selected ungaged site; and

$\mathrm{A}_{\mathrm{g}}$ is the drainage area at gaging station.

The equations given above for transferring low-flow data upstream and downstream are discussed in detail in the section "Estimation Methods For Ungaged Sites on Gaged Streams."

\section{Ungaged Sites Between Gaging Stations}

A low-flow discharge estimate may be needed at an ungaged site between two gaging stations on a given stream. Such an estimate may be made in the same manner as described above in the section "Ungaged Sites on Gaged Streams," using the gaging station nearest the selected ungaged site (with respect to difference in drainage area) as the index gage from which to transfer low-flow information. The estimate also may be made by plotting on log paper the values for the low-flow characteristics with the drainage areas for the upstream and downstream gaging stations. A straight line may be drawn between the two points and an equivalent " $\mathrm{Q}_{0}$ " discharge estimate may be determined from this line at the point where the drainage area is equal to that of the selected site.

\section{Accuracy and Limitations}

Low-flow estimation methods are provided in this report for all of Maryland and Delaware. Accuracy of results to be expected when using regression-based estimation equations is indicated primarily by the average standard errors of prediction of the estimation equations. Accuracy of results to be expected when using the adjustment coefficients, distance-weighted average equation, or transfer equations combining results from 
regional equations and gaging-station data is indicated primarily by the standard deviations of the residuals.

\section{Eastern Shore, Eastern-Piedmont, and Western Regions}

In the Eastern Shore, eastern-Piedmont, and western regions, significant relations between discharge and basin characteristics were identified and quantified by regional regression equations. A useful feature of a regional regression equation is that it not only provides a means of estimating a lowflow characteristic at an ungaged site, but it also provides a means of estimating the uncertainty in the prediction. One measure of the uncertainty in a prediction at an ungaged site is the standard error of prediction (SEp) from the GLS model, where $\mathrm{SEp}=(\text { model variance plus sampling variance })^{0.5}$. A measure of the overall predictive ability of a regression equation can be calculated by averaging the squared standard errors of prediction over a representative set of sites in the region. In this report, it is assumed that the available continuousrecord gaging stations and partial-record gaging stations are a representative set of sites for the region. Average standard errors of prediction, therefore, were computed by taking the square root of the average of the squared standard errors of prediction computed for sites with basin characteristics identical to the characteristics associated with the gaging stations and partial-record stations in the region to which the equation applies.

The observed values for approximately two out of three data points fall within the range of one average standard error of prediction of the computed values (computed by the estimation regression equations.) The average standard error of prediction, assuming the residuals (actual value minus predicted value) are normally distributed about the regression equation, is the range within which two out of three observations from the related population would fall. Average standard errors of prediction have been computed for the low-flow regression equations and are given in table 3.

Standard error of prediction values are somewhat misleading when constants are added to the variables because the magnitude of the standard error values is related to the magnitude of the constants used. The error is minor, however, because the constants used are 0.05 in the western region, and 0.2 in the Eastern Shore region. These are generally small in relation to the actual discharge values. Some caution should be used in interpreting the standard errors given in table 3 . In particular, the standard errors of prediction evaluate the scatter of the combined (discharge plus constant) values and not the scatter of the discharge values only. The interpretation of standard errors of prediction where dependent variables include constants is discussed in more detail in the section "Regression Analyses."

The regression equations for the Eastern Shore and eastern-Piedmont regions, and area underlain by noncarbonate rocks in the western region should be reliable (as reflected by their average standard errors of prediction) within the range of basin characteristics used in their development. The range of values for the basin characteristics used are given in table 4. At stream sites where basin-characteristic values exceed the ranges for the appropriate regions, the reliability of the estimation equations is reduced. Under these conditions, the equations should be applied with caution.

The accuracy of results to be expected when using the adjustment coefficients to determine lowflow characteristics of areas underlain by carbonate rocks in the western region is indicated to some extent by the standard deviation values presented with the adjustment coefficients (table 2). The values (logarithms converted to percent) represent the standard deviations of the residuals (at-site value minus estimated log-transformed low flows) of the data points from 65 stations used in developing the adjustment coefficients. The at-site values are developed by the log-Pearson frequency analysis of station records at the gaging stations or by correlation with index sites for the partial-record stations. The estimated values are the adjusted low flows computed by applying the adjustment coefficients to the results from the western region regression equations for areas underlain by noncarbonate rocks. 
Table 3. Average standard errors of prediction for regression-based equations for estimating low-flow characteristics in Maryland and Delaware

[Average standard error of prediction values given are averages of the negative and positive values of the standard error range in percent. Where the values are large (greater than 50 percent), separate negative and positive values are given in parentheses for clarification. Low-flow characteristics have the number of consecutive days as the leading number and the recurrence interval in years as the subscript; for example, $7 Q_{10}$ is the average annual 7-consecutive-day low-flow discharge with a 10-year recurrence interval. Western region standard errors are for equations for areas underlain by noncarbonate rock]

Eastern-Piedmont region

\begin{tabular}{|c|c|c|c|c|c|c|}
\hline & & & & & & \\
\hline $\begin{array}{l}\text { Low-flow } \\
\text { characteristic } \\
\text { (with constant) }\end{array}$ & $\begin{array}{c}\text { Eastern Shore } \\
\text { region } \\
\text { (constant }=0.2 \text { ) }\end{array}$ & $\begin{array}{l}\text { Subregion A } \\
\text { (constant }=0.0 \text { ) }\end{array}$ & $\begin{array}{l}\text { Subregion B } \\
\text { (constant }=0.0 \text { ) }\end{array}$ & $\begin{array}{l}\text { Subregion C } \\
\text { (constant }=0.0 \text { ) }\end{array}$ & $\begin{array}{l}\text { Subregion D } \\
\text { (constant }=0.0 \text { ) }\end{array}$ & $\begin{array}{l}\text { Western region } \\
\text { (constant }=0.05 \text { ) }\end{array}$ \\
\hline $7 Q_{2}$ & 46 & 16 & 26 & 12 & 17 & $74(-50.98)$ \\
\hline $7 Q_{10}$ & $54(-40,68)$ & 31 & 44 & 20 & 20 & $82(-53,111)$ \\
\hline $7 Q_{20}$ & $58(-42,74)$ & 44 & $55(-41,69)$ & 25 & 23 & $84(-53,115)$ \\
\hline $14 Q_{2}$ & 45 & 16 & 24 & 10 & 18 & $70(-48,92)$ \\
\hline $14 Q_{10}$ & $54(-40,68)$ & 30 & 41 & 19 & 19 & $80(-52,108)$ \\
\hline $14 Q_{20}$ & $57(-42,72)$ & 42 & 48 & 24 & 22 & $80(-52,108)$ \\
\hline $30 Q_{2}$ & 42 & 17 & 22 & 8.9 & 23 & $68(-47,89)$ \\
\hline $30 \mathrm{Q}_{10}$ & $53(-40,66)$ & 24 & 38 & 18 & 21 & $76(-50,102)$ \\
\hline $30 Q_{20}$ & $56(-41,71)$ & 33 & 43 & 23 & 22 & $78(-51,105)$ \\
\hline
\end{tabular}

Standard deviations of the residuals (at-site values minus estimated low-flow values in $\log$ units) were determined as a broad indicator of how accurate the method would estimate low-flow characteristics. A standard deviation is a measure of the scatter of a set of data points (in this case, atsite values minus estimated log-transformed low flows) about the mean. As in standard errors of prediction and standard errors of estimate (Carpenter, 1983), the standard deviation is determined from a set of observations in such a way that, if the residuals are normally distributed, about two-thirds of the data will fall within plus or minus one standard deviation of the mean. Standard deviation values for the western region adjusted equation residuals are similar to the standard errors of estimate values often provided with regression-technique estimation equations.
The coefficient-adjustment method does not apply to situations where the western region estimation equations for areas underlain by noncarbonate rocks yield zero-discharge values. There could be flow in such a situation, especially if a basin contains considerable carbonate rocks; but this method cannot be applied.

\section{Southern Region}

The accuracy of results to be expected when using the distance-weighted average low-flow estimation equation for the southern region is more difficult to evaluate than for the other three regions. In order to develop some indication of the accuracy of the equations applied in the southern region, estimated values based on the recommended method were computed for data at nine gaging 
Table 4. Range of basin characteristics used in developing regression-based equations for estimating low-flow characteristics in Maryland and Delaware

[Type A soils, low runoff potential; type D soils, high runoff potential; for soil types in Maryland see plates 2-10; for soil types in Delaware see Simmons and Carpenter, 1978; --, not determined]

\begin{tabular}{|c|c|c|c|c|c|c|}
\hline \multirow{2}{*}{$\begin{array}{c}\text { Basin } \\
\text { characteristic }\end{array}$} & \multirow{2}{*}{$\begin{array}{l}\text { Eastern Shore } \\
\text { region }\end{array}$} & \multicolumn{4}{|c|}{ Eastern-Piedmont region } & \multirow[b]{2}{*}{ Western region } \\
\hline & & Subregion A & Subregion B & Subregion $\mathrm{C}$ & Subregion D & \\
\hline $\begin{array}{l}\text { Drainage area } \\
\text { (square miles) }\end{array}$ & 2.45 to 113 & 2.45 to 101 & 2.01 to 165 & 2.09 to 133 & 3.05 to 287 & 1.95 to 875 \\
\hline $\begin{array}{l}\text { Mean-annual } \\
\text { precipitation } \\
\text { (inches) }\end{array}$ & -- & -- & - & -- & -- & 35.5 to 52.0 \\
\hline $\begin{array}{l}\text { Forest cover } \\
\text { (percent) }\end{array}$ & 0 to 85 & - & - & -- & -- & - \\
\hline $\begin{array}{l}\text { Type A soil } \\
\text { (percent) }\end{array}$ & 0 to 82 & -- & -- & -- & -- & -- \\
\hline $\begin{array}{c}\text { Type D soil } \\
\text { (percent) }\end{array}$ & 0.6 to 100 & -- & -- & -- & - & - \\
\hline
\end{tabular}

stations in the Maryland part of the region, where there were minimal intercorrelations between data at the selected stations and any of the bordering stations appropriate for use in the estimation equation. None of the nine test stations were related to any of the bordering stations through the correlation process used to develop low-flow characteristics at the partial-record gaging stations.

When the southern region estimation equation was applied to the nine-station test-data set, the standard deviation for the $7 \mathrm{Q}_{2}$ low-flow estimates was 114 percent (-62 to 165 percent), and for the $7 Q_{10}$ low-flow estimates it was 134 percent (-67 to 200 percent). A constant of 0.1 had been included in the at-site values and estimated values in both the $7 Q_{2}$ and $7 Q_{10}$ data sets in order to use logarithms to be able to use zero-flow data sites in the statistical evaluation. The standard deviation values indicate the distance-weighted average method is not an accurate solution. This method, however, at least provides a reasonable approach to estimating the low-flow characteristics in this region.

The southern region estimation method is considered reliable only in the area south of the Patapsco River as there are no station data available north of the Patapsco in the southern region. The part of the southern region north of the Patapsco is very narrow, and the eastern-Piedmont region equations apply to most of the drainage area contributing to the streams in this area. The results from the applicable eastern-Piedmont subregion equations for a given stream at the Piedmont regional boundary probably can be extrapolated 
downstream (by drainage-area ratio) to any point in the northern part of the southern region, with little loss of accuracy.

\section{Ungaged Sites on Gaged Streams}

The accuracy of results to be expected when using the transfer method for estimating low flows at ungaged sites on gaged streams should be significantly better than the accuracy of estimates based only on the regional estimation equations. This should be especially true when the selected site is reasonably close to the index station; for example, upstream within 75 percent of the drainage area of the gaged basin, or downstream within 100 percent of its area. These conditions are necessarily somewhat subjective. Considerably more insight into the transfer limits of this method is provided in the section "Estimation Methods for Ungaged Sites on Gaged Streams," and especially in the evaluation of the method, where some statistical indications of accuracy are included.

\section{Other Considerations}

All of the estimation equations were developed from data on essentially unregulated streams. The equations are not considered reliable for streams where low flows are affected to a significant degree by urban development or regulation. The equations also are not applicable where significant parts of the drainage basins are tidal marshes.

Estimation equations do not apply to larger recurrence intervals of low-flow discharges than those designated in the equations. This is because of uncertainties involved in determining the lowflow-frequency curves at the gaging stations from which the estimation equations were developed. These uncertainties are discussed in the section "Accuracy and Limitations" under "Low-Flow Characteristics at Gaging Stations."

Application of the equations to determine low flows for basins that overlap the boundaries between regions should be carefully analyzed. If the overlap is significant, for example, greater than 10 percent, the discharge should be computed separately, as though the basin were entirely in each region. The two results are then combined, weighted by the percentages of the total basin in each region. If the overlap is not significant, the equation for the region in which most of the basin is located should give acceptable results. Delaware soils maps must be obtained from a previously published report (Simmons and Carpenter, 1978) in order to make the necessary computations for the Eastern Shore region if a drainage basin lies in Delaware.

The transferability of generalized low-flow information is not considered to be as reliable as the transferability of peak-flow data. Most of the variability in low-flow characteristics calculated at gaging stations (unaccounted for in regression equations) is believed to result from geologic conditions at the individual basins rather than from time-sampling error. Therefore, estimates of lowflow characteristics at gaging stations (including those from which low-flow information is inferred at ungaged sites on gaged streams) are based on gaging-station data only, rather than on gaging-station data combined with discharge estimates from regionalized equations, as is often done with peakflow estimation methods.

The regression equations as defined, cannot be applied in metric units. To obtain answers in cubic meters per second, discharges must be computed first in cubic feet per second and then multiplied by 0.0283 .

\section{Development of Estimation Methods}

The low-flow estimation methods presented in this report are based on the flow records from 221 continuous-record and partial-record gaging stations (see pl. 1). There were 167 stations in Maryland, 28 in Delaware, 15 in Pennsylvania, 7 in West Virginia, and 4 in Virginia. Three additional gaging stations in Maryland were specifically used to evaluate low-flow conditions in the Bynum anomaly area (see section "Accuracy and Limitations" for ungaged locations).

A number of gaging stations were excluded from the analysis for various reasons: stations with drainage basins affected by significant regulation or undergoing development, high-density stations (in parts of the study area having overrepresenta- 
tions of stations), and partial-record gaging stations having poor correlations with index stations (those with $R^{2}$ values less than 0.8 ), or with less than eight discharge measurements. Also excluded were stations too close to stations included in the analysis on the same streams, most stations with drainage areas greater than $1,000 \mathrm{mi}^{2}$, and approximately 10 stations considered as outliers. A station was considered too close to a station included in the analysis if the intervening drainage area between stations was less than 50 percent of the drainage area at the included station. A few stations with drainage areas greater than $1,000 \mathrm{mi}^{2}$ were included in the analysis, but only for evaluation of the method for estimating low-flow characteristics upstream and downstream from gaging stations (see table 7).

Low-flow characteristics were estimated from frequency curves developed by log-Pearson Type III analysis using daily discharge records at the selected continuous-record gaging stations and by the moment-estimator transfer technique at the selected partial-record gaging stations (Stedinger and Thomas, 1985). Available discharge data through March 1988 were included in the analysis. All the continuous-record gaging stations used had at least 10 years of low-flow discharge data, and were considered partial-record gaging stations if less record were available. For stations with periods of regulated and unregulated streamflow, only data from the unregulated periods were used in the analysis.

\section{Estimation Methods for Ungaged Streams}

The regional low-flow estimation methods were based on low-flow characteristics at the continuous-record and partial-record stations as well as nine basin characteristics that were assumed to potentially have an effect on low-flow characteristics and were quantified for the basins used in the analysis. These basin characteristics included drainage area; channel length; channel slope; basin elevation; area of lakes, swamps, and ponds; forest cover; mean-annual precipitation; and, in the Eastern Shore area of the Coastal Plain Province, the extent of two different soil types (A and D) categorized by runoff potential (type A, low runoff potential; type $\mathrm{D}$, high runoff potential). The soil types analyzed were classified by the Natural Resources Conservation Service (formerly U.S. Soil Conservation Service)in a system that qualitatively groups soils according to various physical and chemical properties (Maryland Department of State Planning, 1973). The qualitative groupings, arranged by runoff potential, were delineated on, and evaluated from, natural soil-group maps obtained from the Natural Resources Conservation Service.

The stations from each region that were used in developing the estimation methods are given in table 5 and their locations are shown on plate 1 . The nine basin characteristics, along with the coordinates of the stations (latitudes and longitudes), are presented in table 10 for continuous-record gaging stations and in table 12 for partial-record gaging stations. Nine low-flow characteristics, $7 \mathrm{Q}_{2}$ through $30 \mathrm{Q}_{20}$, as covered by the estimation equations, are presented in table 11 for continuousrecord gaging stations and table 12 for partialrecord gaging stations. For continuous-record gaging stations, length of record (in climatic years) and first year of record are also presented in table 11. For partial-record gaging stations, equivalent years of record values and the years in which baseflow observations were made are presented in table 12.

\section{Regression Analyses}

To obtain gaged low-flow data coverage in the field from all the streams in any region is economically impractical. Therefore, a method is needed for estimating low-flow characteristics at ungaged sites. In this study, multiple-regression analysis was used to develop a low-flow estimation method for three regions--the Eastern Shore, eastern-Piedmont, and western regions. The GLS regression technique (Tasker and Stedinger, 1989) was used in place of the older, more frequently used ordinary least-squares (OLS) regression technique. The GLS regression technique was chosen for this study primarily because streamflow data (dependent variable) can be weighted for the various gaging stations to account for the difference in accuracy and the relative independence of the atsite low-flow characteristics used in the data base. The OLS regression technique can only equally weight all the input streamflow data. The variable 
weighting ability of the GLS regression technique is particularly important for use with composite data bases of continuous-record and partial-record gaging stations, as was done in this study. The variable weighting is especially important because at-site low-flow estimates for partial-record gaging stations are significantly less accurate (based on substantially less information) than the at-site lowflow estimates for continuous-record gaging stations. The GLS regression technique also weights at-site low-flow estimates at continuous-record stations according to the variance and record length of the annual series of $\mathrm{NQ}_{\mathrm{T}}$ low flows. The continuous-record and partial-record station data are weighted according to equivalent years of record. In addition, the technique weights low-flow estimates at gaging stations according to the cross correlation of annual-series' low-flow values with nearby sites. As a result, the data-weighting capability of the GLS regression technique provides improved estimates of the regression coefficients of the multiple-regression models. Use of the GLS regression technique for regionalizing low-flow characteristics is described in detail in Tasker (1989).

Equivalent years of record are determined as the number of complete years of streamflow record available for continuous-record stations. Equivalent years of record were determined for the partial-record stations, based primarily on the number of years of base-flow observations and on the relative goodness-of-fit of the correlations with the corresponding index stations. Half the period of record at the corresponding index station was established as an upper limit for the equivalent years of record at a partial-record gaging station. A lower limit was set as the number of years in which base-flow observations were made.

The reliability of regression equations can be largely determined by relative average standard errors of prediction. The average of the standard errors of prediction at sites with basin characteristics identical with the at-site data used in the lowflow regression equations in this report are presented in table 3 . These values of average standard errors of prediction give indications on the predictive accuracy of the equations when applied to an ungaged site. Constants were added to the discharge (dependent) variables in models for two of the regions, requiring some precaution in interpretation of standard errors. The average standard errors of prediction for the low-flow equations developed in the regression analyses range from 9 to 25 percent for subregion $\mathrm{C}$ of the eastern-Piedmont region to 68 to 84 percent for the western region.

A series of GLS regressions were computed to evaluate the effect of the nine basin characteristics previously mentioned on each of the nine low-flow characteristics. A backward elimination-type regression technique was used to determine the significant basin characteristics for application in the various sets of low-flow estimation (regression) equations. A 95-percent confidence level was used as the criterion for significance. All basin characteristics in all the regression equations meet this criterion except for forest cover in the Eastern Shore region, which was slightly less than 95 percent in the $\mathrm{NQ}_{10}$ and $\mathrm{NQ}_{20}$ model calibrations.

The region boundaries (pl. 1) are the same as in Carpenter (1983). The region boundaries were based on a generalized geologic map (Maryland Geological Survey, 1967), a map of physiographic provinces (fig. 1), and a map plot of the 25/90 flow-duration indices for the gaging stations in the Carpenter (1983) analysis. The 25/90 index is the ratio of daily mean discharges exceeded 25 percent of the time to the discharges exceeded 90 percent of the time. A consistent pattern of flow-duration indices interpreted in conjunction with the geologic map defined the boundary used between the western and the eastern-Piedmont regions. Plots of the residuals from the regional regression equations gave no indications that the primary region boundaries defined in Carpenter (1983) should be changed. The eastern-Piedmont region, however, was further subdivided into four subregions (pl. 1) based on the residual analysis and soils information (James Brown, U.S. Department of Agriculture, Natural Resources Conservation Service, oral commun., 1991). The residual analysis was made by including all the gaging stations in the easternPiedmont region in trial GLS regression 
Table 5. Streamflow-gaging stations used in regional analyses of low-flow frequencies in Maryland and Delaware

[Noncarbonate rocks, stations in which none of the basin area is underlain by carbonate rocks; carbonate rocks, stations in which some of the basin area is underlain by carbonate rocks. See plate 1 for regions and subregions]

\begin{tabular}{|c|c|c|c|c|c|c|c|}
\hline \multirow{3}{*}{$\begin{array}{l}\text { Eastern Shore } \\
\text { region }\end{array}$} & \multicolumn{6}{|c|}{ Gaging-station number } & \multirow{3}{*}{$\begin{array}{l}\text { Southern } \\
\text { region }\end{array}$} \\
\hline & \multicolumn{4}{|c|}{ Eastern-Piedment region } & \multicolumn{2}{|c|}{ Western region } & \\
\hline & $\begin{array}{c}\text { Subregion } \\
\mathbf{A}\end{array}$ & $\begin{array}{c}\text { Subregion } \\
\text { B }\end{array}$ & $\begin{array}{c}\text { Subregion } \\
\text { C }\end{array}$ & $\begin{array}{c}\text { Subregion } \\
\text { D }\end{array}$ & $\begin{array}{c}\text { Noncarbonate } \\
\text { rocks }\end{array}$ & $\begin{array}{l}\text { Carbonate } \\
\text { rocks }\end{array}$ & \\
\hline \multicolumn{8}{|c|}{ Continuous-Record Gaging Stations } \\
\hline 01483200 & 01642500 & 01587000 & 01577500 & 01476500 & 01559700 & $01613500^{\mathrm{a}}$ & 01590000 \\
\hline 01483500 & 01643500 & 01587500 & 01580000 & 01477000 & 01561000 & 01614500 & 01594500 \\
\hline 01484000 & 01645000 & 01588000 & 01581700 & 01478500 & 01595300 & 01617800 & 01594600 \\
\hline 01484100 & 01650500 & 01591500 & 01582000 & 01480000 & 01596500 & 01619000 & 01594800 \\
\hline 01484500 & -.---..- & 01593500 & 01583000 & 01481000 & 01597000 & --------- & 01653600 \\
\hline 01485000 & -------- & 01594000 & 01583500 & 01495000 & 01599500 & -------- & 01658000 \\
\hline 01485500 & --.---.-- & -------- & 01584500 & 01496000 & 01601000 & --.---.- & 01661000 \\
\hline 01486000 & -.....-- & -......... & 01589200 & 01496200 & 01603000 & - & 01661050 \\
\hline 01487000 & ------ & -----.... & 01589440 & 01578500 & 01603500 & -...-.--- & 01661500 \\
\hline 01488500 & - & -..-- & --.----- & -..-- & 01606000 & --.--.. & 01661800 \\
\hline 01489000 & --.--..- & --.--.-- & --.--..- & -......- & 01609000 & - & 01668500 \\
\hline 01490000 & -.......... & -........... & ------- & -......-- & 01609500 & --.--.--.- & -...-...- \\
\hline 01491000 & -----.--- & ---.---- & -------- & ---.---.- & 01612500 & ---.......- & -..-- \\
\hline 01493000 & -...-..- & -----.-- & --------- & ........... & 01613050 & -...-..-- & ---.--- \\
\hline 01493500 & --.--- & -.......... & -....... & -.......-- & 01613500 & -------- & --.--- \\
\hline -......-. & -.......... & -........... & -......... & -.-.---.- & 01613900 & -..--..-- & -...-..- \\
\hline -...-.... & -......... & -......... & -----.--- & -..-...-. & 01614090 & -------- & -..---- \\
\hline -...---- & -...-- & -........- & ----.--- & -........ & 01637000 & -..----- & --.-- \\
\hline -.---.-- & -...-..- & -.......- & -........ & - & 01637500 & -.......... & -.--..-- \\
\hline --.---.- & -..-- & -........ & -..........- & --.------ & 01638480 & -........... & --.---.-- \\
\hline -------. & --..-- & -......- & -.----- & --.----- & 01639000 & -....-..- & -..--.-- \\
\hline - & -.......... & -..---- & --...-..- & -------- & 01640500 & ---.---- & --.---- \\
\hline …-..... & -----..- & -..-...- & --.-- & -------- & 01641000 & ----...-.. & --..-- \\
\hline -.-.-.-... & -...-...- & ----..-- & ------- & -------- & 01641500 & --.-.--- & -.-..- \\
\hline -...- & - & -..... & -....... & -----.--- & 03039200 & -..--.---- & -.......... \\
\hline -..--.--- & -.----... & -...-.... & -...-.... & -------- & 03062400 & --.-.--. & ------- \\
\hline -.------- & --.---- & -...----- & -.--..-- & ------- & 03062500 & -.........- & -........ \\
\hline -.--.-.-. & -....... & - - & -..-... & -.---- & 03065000 & -..-..-- & -..-- \\
\hline -.---.--..- & -..--..-. & --.--.-- & -.--.-- & -..--.-- & 03066000 & -.-----.- & - \\
\hline ------- & -----.- & -.-.-- & ---.-.--- & ........... & 03075500 & -.------ & -.-...- \\
\hline 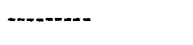 & -----.--- & -.--.-.--- & ---.-.--- & --.------ & 03076600 & -------.- & -.......- \\
\hline --------. & -..---1.-. & - - - & -------- & --.--- & 03078000 & --.-.-.-- & - \\
\hline -..-..... & -.---.-- & -----.---- & ------.-- & --.-.---- & 03079000 & -..---.-- & --------- \\
\hline -..-....... & -.-.-..- & -------- & -------. & -------- & 03080000 & -.----.- & --.--.-- \\
\hline -..-..-.... & - & - - & --...--- & ------- & 03082200 & -...-.--- & -......... \\
\hline
\end{tabular}

\footnotetext{
a Station also used in western region analysis.
} 
Table 5. Streamflow-gaging stations used in regional analyses of low-flow frequencies in Maryland and Delaware--Continued

\begin{tabular}{|c|c|c|c|c|c|c|c|}
\hline \multirow{3}{*}{$\begin{array}{c}\text { Eastern Shore } \\
\text { region }\end{array}$} & \multicolumn{6}{|c|}{ Gaging-station number } & \multirow{3}{*}{$\begin{array}{l}\text { Southern } \\
\text { region }\end{array}$} \\
\hline & \multicolumn{4}{|c|}{ Eastern-Piedmont region } & \multicolumn{2}{|c|}{ Western region } & \\
\hline & $\begin{array}{c}\text { Subregion } \\
\text { A }\end{array}$ & $\begin{array}{c}\text { Subregion } \\
\text { B }\end{array}$ & $\begin{array}{c}\text { Subregion } \\
\text { C }\end{array}$ & $\begin{array}{c}\text { Subregion } \\
\text { D }\end{array}$ & $\begin{array}{c}\text { Noncarbonate } \\
\text { rocks }\end{array}$ & $\begin{array}{l}\text { Carbonate } \\
\text { rocks }\end{array}$ & \\
\hline \multicolumn{8}{|c|}{ Partial-Record Gaging Stations } \\
\hline 01482298 & 01591650 & 01585500 & 01577950 & 01477400 & 01594975 & 01614525 & 01589090 \\
\hline 01483150 & 01591700 & 01586200 & 01579875 & 01479500 & 01596200 & 01614577 & 01589500 \\
\hline 01483300 & 01642450 & 01586600 & 01579900 & 01481400 & 01596600 & 01614675 & 01589800 \\
\hline 01483350 & 01643400 & 01586650 & 01579925 & 01495500 & 01597100 & 01617600 & 01594455 \\
\hline 01483680 & 01644480 & 01587170 & 01580170 & 01496050 & 01598980 & 01619050 & 01660740 \\
\hline 01484020 & 01644500 & 01590900 & 01581850 & 01579000 & 01601325 & 01619325 & 01660905 \\
\hline 01484040 & 01647620 & 01591350 & 01581960 & ------- & 01605425 & 01619350 & ------.. \\
\hline 01484050 & 01650050 & 01593200 & 01581980 & --.---- & 01608975 & 01619480 & - \\
\hline 01484060 & ----..... & 01593600 & 01582900 & ------.- & 01610060 & 01638600 & --.-.... \\
\hline 01484200 & -------- & 01593650 & 01583100 & -------- & 01610065 & 01643125 & --.....-- \\
\hline 01484240 & --.--- & 01594100 & 01583200 & -.-.-... & 01610075 & -......- & …… \\
\hline 01484270 & -...-..- & 01639400 & 01583600 & -.----- & 01610150 & -.-.-...- & --.---- \\
\hline 01484550 & - & 01639420 & 01584200 & - ----- & 01613150 & - & …-- \\
\hline 01484700 & ------- & 01639470 & 01589230 & …---- & 01613540 & -------- & ------ \\
\hline 01486200 & -..--.-- & 01640100 & $01581500^{b}$ & -.------- & 01636730 & 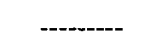 & ------- \\
\hline 01487100 & - & 01640160 & $01581600^{b}$ & -........ & 01636850 & -ב--- & ---..... \\
\hline 01487120 & -..-- & --.-...-- & $01581650^{b}$ & -.....-- & 01636975 & -------- & - - \\
\hline 01487300 & -.---- & -------- & -.......- & -----.- & 01639325 & -..-- & -....-- \\
\hline 01487700 & ------- & --.--- & ------- & -.----. & 01640650 & - & ……- \\
\hline 01489395 & -...----- & -------.. & --------- & -.------- & 01640720 & --.-.---- & -......... \\
\hline 01489400 & -..---- & -......... & -..-- & ------ & 01640965 & -..-- & --...-- \\
\hline 01489500 & ----.-- & - - & -------- & -.-.--- & 01643615 & -...-- & ---.--- \\
\hline 01491060 & -------- & --..---- & ------- & - & 03075400 & ---.---- & --.-- \\
\hline 01491180 & -.--.-- & --..--..- & --.--.--- & -------- & 03075475 & --------- & --.--- \\
\hline 01491500 & --------- & -.-.--..- & ---..---- & -----.---- & 03075700 & ------- & -------- \\
\hline 01491800 & …--.-- & -..----- & -..---- & -..--.-- & 03075900 & -.---.--. & - -...---. \\
\hline 01492080 & ------- & ------- & -.......-- & --_--- & 03076580 & --.--- & -----.- \\
\hline 01492500 & ---.--.. & --........ & -------. & ----.-.- & 03076590 & --.---- & ---.-- \\
\hline 01492560 & --...... & -------- & ------- & --------- & 03077925 & -------- & -.......- \\
\hline 01492980 & ----- & ------- & -...--.-- & ---o-- & 03077950 & - -.-.-- & -......- \\
\hline 01492990 & -.......... & -...--..- & ------- & $-\cdots$ & -..--.-- & ---.---- & -----... \\
\hline 01493480 & - & ------- & --..-.-- & ---.-- & -----... & -.....-- & -----..- \\
\hline 01494000 & -....... & - & ------.. & -------- & -..-...- & -..--..- & -.-...... \\
\hline 01494035 & ---.... & --.-- & -------- & -------- & --.---..- & -.--.--- & ---.---- \\
\hline 01494100 & -.---n-- & -.------ & 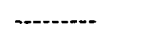 & 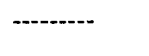 & - & 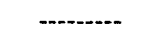 & $\cdots$ \\
\hline 01494500 & -..- & --.--.- & - --.--..- & -------. & -....... & -----.-- & ------. \\
\hline 01494600 & -....... & --..-- & -.----- & ------- & ------- & ---.---- & --..-- \\
\hline 01495800 & --.---.- & -----..-- & --.----- & ----..--- & -.----... & --..----- & ---.---- \\
\hline 01495935 & 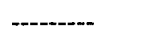 & ------ & ------- & ------ & -...--- & -------- & ----.--- \\
\hline
\end{tabular}

${ }^{b}$ Station located in Bynum anomaly. 
computations and plotting the residuals on a map of the region. Residuals ( $\log \mathrm{Q}_{\text {observed }}$ minus $\log$ $Q_{\text {estimated }}$ ) from $7 Q_{2}$ and $7 Q_{10}$ regression computations were analyzed. Well-defined clustering of the positive and negative residuals was evident on the map plots, and was used as the basis for delineating the four subregions. Residual plots from regression computations of data in the subdivided regions appeared to be areally random.

Effective GLS regression models were developed for the Eastern Shore region, the four subregions of the eastern-Piedmont region, and the western region. In the Eastern Shore region, the final model included drainage area, type A soil, and type D soil, all of which were found to be highly significant. Forest cover also was included because it improved the standard errors of estimate by 4 to 5 percent (throughout the family of lowflow regression equations) computed after the constant $\left(0.2 \mathrm{ft}^{3} / \mathrm{s}\right)$ was removed from the at-site and estimated discharges. The standard error of estimate improved even though forest cover was significant only at the 90-percent level with the $\mathrm{NQ}_{10}$ and $\mathrm{NQ}_{20}$ regression equations $(95$ percent with the $\mathrm{NQ}_{2}$ equations). In addition, a check for continuity of estimation-equation results was made by computing sets of low-flow characteristics by the estimation equations, using a wide range of values for forest cover and type A soil while holding the other basin characteristics constant at normal (likely to be encountered) values. The progression of results was monotonic; for example, $7 Q_{20}$ was less than the $14 Q_{20}$ which was less than the $30 Q_{20}$. Results of the low-flow equations were not tested for continuity with respect to drainage area or type D soil because the progression of exponents associated with drainage area and type $\mathrm{D}$ soil in the matrix of low-flow (7-, 14-, and 30-day and 2-, 10-, and 20year) estimation equations indicated adequate stability with respect to these variables.

In the eastern-Piedmont region, subregion boundaries were drawn (pl. 1) to fit the pattern of residual clustering and to correspond with physiographic features. Subregion A includes the area southwest of the main stem of the Patuxent River and the part of the Monocacy River Basin downstream from the confluence with Double Pipe Creek. Subregion B includes the area northeast of the main stem of the Patuxent River, the main-stem Patapsco River Basin upstream from Anne Arundel County, and the part of the Monocacy River Basin upstream from, and including, the Double Pipe Creek Basin. Subregion C includes the area east of the Monocacy River Basin and east of the main-stem Patapsco River Basin upstream from Anne Arundel County, and west of the main stem of the Susquehanna River. Subregion $\mathrm{C}$ was further subdivided to delineate the Bynum anomaly. Subregion D includes all of the area east of the main-stem Susquehanna River. In the final eastern-Piedmont region regression models, drainage area is the only basin characteristic applied. Drainage area was the only basin characteristic found to be significant before subdividing the region, and also the only one found significant in model analysis of the subregions. A small anomalous area (the Bynum anomaly) having extremely low flows was identified within subregion C (pl. 1) as preliminary GLS regression computations were made on the entire eastern-Piedmont region. This small area, defined by three gaging stations, 01581500 , 01581600 , and 01581650 , includes the Bynum Run and James Run Basins, both tributary to Bush River. This area had very large negative residuals (average $7 Q_{10}$ residual of -2.6 in logarithmic units) in the preliminary regressions, and it is isolated in a much larger area of gaging stations having only positive residuals within $19 \mathrm{mi}$ of the anomalous area. Low-flow estimates on ungaged streams within the anomaly may be made by averaging the flow at the three gaging stations, as described in the section "Other Considerations." Since the reason for the disparity between low flows inside and outside the Bynum anomaly is unknown (it could be caused, in part, by withdrawals from the surficial aquifer), any estimates of flow should be used with caution.

In the western region, drainage area and mean-annual precipitation were the only basin characteristics applied in the final model for areas underlain by noncarbonate rocks. Mean-annual precipitation is used with a constant in the model, in the form 60 minus precipitation in inches (60-P). This transformation is used because after testing several alternatives, including precipitation with no constant, it was determined this transformation (60-P) improves the standard errors of the regres- 
sion equations slightly and resultant coefficients for the equations and exponents for the precipitation variable that are more reasonable. A sensitivity analysis was evaluated with the transformed precipitation variable. The results appeared reasonable through the range in mean-annual precipitation ( 35 to 52 in.) probable in the western region. Gaging stations that have part of their drainage basins in an area underlain by carbonate rocks were excluded from the final western region regression model. Gaging-station areas underlain by carbonate rocks were tested but were not included in the final model because the percentage of carbonate rocks was not a significant variable (even at the 90-percent level). Also, the relation between the percentage of area underlain by carbonate rocks and low-flow discharge was not linear. Consequently, the estimation equations do not apply to sites all or partly within areas underlain by carbonate rocks (in Washington and Frederick Counties) in the western region unless the results are adjusted as discussed in the section "Sites in Western Region." The equations applied in the western region tend to produce high estimates of low flows in the small area east of the Town Creek Basin over to (and including) the Tonoloway Creek Basin (see pl. 1). An alternative method for estimating low flows on ungaged streams in this area would be to transfer in an average of flow values (inversely weighted by distance) from nearby gaging stations, similar to the method presented for the southern region, perhaps making only rough estimates of drainage-basin center locations. (See description in the section "Sites in Southern Region.")

The precipitation map (fig. 2) used with the western region equations is based on precipitation records from 1931 through 1955 . This time period is considered the most practical choice for this study for the following reasons: (1) the five State maps used to develop the composite map (Maryland/Delaware, Pennsylvania, West Virginia, Virginia, and New Jersey) (see U.S. Weather Bureau, 1959a, 1959b, 1959c, 1960a, and 1960b) were all based on the same time period (1931-55) and it is believed that since that time, no more sets of meanannual precipitation maps have been published for the six States based on a common time period; (2) it is generally believed there are no short-term cli- mate-change trends in this five-State area, and the selected time period is just as likely to be representative of the next 25 or 50 years as would be the period, for example, from 1966 to 1990 ; (3) the mean-annual precipitation values for the gaging stations applied in the regression model have been obtained from the 1931-55 isohyetal maps, to be consistent with data in previous reports.

Constants were used with the low-flow discharge values (dependent variable) in the GLS multiple-regression analyses for the Eastern Shore and western regions. The constants allowed the inclusion of zero-discharge data points (logarithm of zero is undefined) and to reduce the large effect of small discharge values (less than about $0.3 \mathrm{ft}^{3} / \mathrm{s}$ ). With relatively small discharges, residuals stated in logarithms can be very large (with very little difference in discharge) and unduly affect the regression analysis. The constants used were optimized by a trial-and-error process, applied primarily to the $7 Q_{2}$ and $7 Q_{10}$ characteristics and making several GLS regression computations with a range of different constants from 0.01 to 1.0. After the regression computations were made, the constants were subtracted from the actual and the predicted discharge values. The standard errors of estimate and the means of the residuals of the logarithms of the adjusted data points from each regression run were compared. These comparison of statistics were made excluding the residuals for sites with predicted discharge values less than $0.3 \mathrm{ft}^{3} / \mathrm{s}$. For these low-discharge sites, the differences in discharge (actual minus predicted arithmetic values after the constants were subtracted) were visually compared among the models testing the effect of different discharge constants.

The final regression models chosen were those which provided (after the constants were subtracted) the optimal combination (qualitatively) of means and standard errors of estimate of the residuals and, for the low-discharge data points, small arithmetic residuals. The optimum mean, for example, should be near zero to be indicative of an unbiased estimation equation. The model selection was also based on using the smallest constant possible, commensurate with optimization of the standard errors and residuals, after the constants were 
subtracted. Constants were used with the discharges with the Eastern Shore and western region models.

The standard error of prediction (and estimate) values tend to be somewhat misleading for the low-flow regression models with constants added to the discharges. Values can be misleading because variables are transformed into logarithmic form prior to application of the multiple-regression technique. The magnitude of the standard errors is related to the magnitude of the constants added. For example, assume a constant of 100 is added to a set of $y$ (dependent variable) values ranging from 0 to 10 . The revised set ranges in value from 100 to 110 . It should be apparent that when these values are log-transformed, the set ranging from 100 to 110 has much less variance around the mean than the set ranging from 0 to 10 has around its mean. Similarly, a constant in the order of 0.5 is added to a set of values with observations ranging down to around 0.01 .

Results from this study are that the constants applied with the final models were small enough $(0.2$ and 0.05$)$ to have relatively little effect on the standard errors of prediction. Considerable care should be taken when interpreting the meaning of standard errors where constants are used with discharge values. It must be realized that the standard errors evaluate the scatter of the combined (discharge plus constant) values and not the scatter of the discharge values only.

All the basin and flow characteristics used in the GLS regression analyses were transformed into logarithms based on the assumption of log-linear relations between the independent (basin-characteristic) and dependent (discharge) variables in the regression models. Since the type A soil, type D soil, and forest cover can have zero values, a constant was added to these characteristics (as was done with the discharge values) because the log of zero is undefined. A constant of 10.0 was applied to the soil characteristics and with forest cover for the same reasons as in Carpenter (1980), and to be consistent with the previous low-flow analysis (Carpenter, 1983). A constant of 10.0 was applied instead of a smaller value, such as 0.1 or 1.0 , in order to provide a more nearly linear transition in log-transformed values through the range of percentages expected for the basin characteristics. This provides a more reasonable transition in lowflow estimates in relation to percentage changes in basin characteristics.

The basin characteristics used in the final regression models were plotted with the residuals, testing for nonlinearity. The relations appeared to be essentially linear. The residuals were plotted on a map of the gaging stations to test for areal bias in the regression equations. There was no apparent bias.

In the western region, carbonate rocks are at or near the surface in a substantial part of Washington and Frederick Counties. Carbonate rocks significantly affected low-flow characteristics in this region, even though no significant linear relation was found with discharge and percentage of area underlain by carbonate rocks. At-site values were, on average, many times greater than predicted values (based on the estimation equations for areas underlain by noncarbonate rocks) for the various low-flow characteristics for basins containing carbonate rocks. More specifically, the geometric mean ratios of at-site flow to predicted flow ranged from 5.4 for the $30 \mathrm{Q}_{2}$ low flows to 11.2 for the $7 \mathrm{Q}_{20}$ low flows.

In the western region, there are 14 gaged basins with at least part of the basin underlain by carbonate rocks. The 14 gaging stations are shown on plate 1 and are listed in tables 5 and 6 . These gaged basins were treated separately from the 65 gaging stations used in the primary GLS regression model for the western region in order to develop a method to estimate the effect of areas underlain by carbonate rocks on low-flow characteristics. Gaged basins with areas underlain by carbonate rocks were originally included in the western region model, but preliminary analysis indicated the relation between the percentage of area underlain by carbonate rocks and low flows was tenuous and nonlinear. For example, in the $7 \mathrm{Q}_{2}$ regression, the percentage of area underlain by carbonate rocks was significant at only a 78-percent level, and in the $7 Q_{10}$ and $7 Q_{20}$ regressions it was significant at only a 50 -percent level. 
Table 6. Percentage of basin area underlain by carbonate rocks at gaged basins in carbonate areas of the western region of Maryland

\begin{tabular}{lll}
\hline $\begin{array}{l}\text { Station } \\
\text { no. }\end{array}$ & $\begin{array}{l}\text { Area underlain } \\
\text { by carbonate rocks } \\
\text { (percent) }\end{array}$ & $\begin{array}{l}\text { Drainage } \\
\text { area (square } \\
\text { miles) }\end{array}$ \\
\hline
\end{tabular}

\begin{tabular}{ccc}
\hline & Continuous-Record Gaging Stations \\
01613500 & 17 & 158 \\
01614500 & 42 & 494 \\
01617800 & 100 & 18.9 \\
01619000 & 47 & 93.5
\end{tabular}

\section{Partial-Record Gaging Stations}

01614525

01614577

01614675

$\begin{array}{rc}87 & 9.67 \\ 100 & 9.49 \\ 99 & 7.94 \\ 100 & 3.00 \\ 49 & 24.5 \\ 49 & 22.9 \\ 52 & 8.70 \\ 39 & 24.4 \\ 32 & 20.3 \\ 40 & 20.2\end{array}$

The relation between area underlain by carbonate rocks and low streamflow at the 14 affected gaging stations was evaluated by a secondary regression analysis. The percentage of area underlain by carbonate rocks for the 14 gaging stations (see table 6) was analyzed, as follows, in relation to the discharge for the low-flow characteristics at those sites:

The first step was to compute low-flow characteristics from the estimation equations for area underlain by noncarbonate rocks for the western region at each of the 14 stations. The difference between the actual values (based on station record) and the predicted values (computed by the estimation equations) was then determined at each of the 14 sites as a ratio $\left(\mathrm{Q}_{\mathrm{obs}} / \mathrm{Q}_{\text {pred }}\right)$. These ratios were then regressed against the percentage of area underlain by carbonate rocks for the various lowflow characteristics with dependent and independent variables log-transformed. One station $(01617600)$ was determined to excessively affect regression results because of very small predicted discharge values causing highly exaggerated residuals in $\log$ units, and the station was excluded from the data base. The relations between the percentage of area underlain by carbonate rocks and the ratios $\left(\mathrm{Q}_{\mathrm{obs}} / \mathrm{Q}_{\text {pred }}\right)$ determined by the regression computations on the remaining 13 stations were then examined. These regressed relations enabled discharge estimates, adjusted for area underlain by carbonate rocks, to be computed by multiplying the ratios $\left(\mathrm{Q}_{\text {obs }} / \mathrm{Q}_{\text {pred }}\right)$, estimated by these regression relations, by $Q_{\text {pred }}$ from the equations for basins underlain by noncarbonate rocks. The relations were, however, found to be statistically very insignificant. For example, the relation was significant at only a 78-percent level $(T=1.30)$ for the $7 \mathrm{Q}_{2}$ regression and at only a 50-percent level $(T=0.71)$ for the $7 \mathrm{Q}_{10}$ regression. Coefficient of determination $\left(R^{2}\right)$ values were low (for example, 0.043 for $\left.7 \mathrm{Q}_{10}\right)$.

The $\mathrm{Q}_{\text {obs }} / \mathrm{Q}_{\text {pred }}$ ratios determined by applying the western region estimation equations for basins underlain by noncarbonate rocks to each of the 13 stations containing some area underlain by carbonate rocks were then analyzed for each low-flow characteristic. The ratios were converted to $\log$ units and treated as residuals. The mean $(X)$ and standard deviation (SD) were determined for each low-flow characteristic, such as $7 Q_{2}$. The mean of the residuals was then converted to the geometricmean ratio in arithmetic units, and was applied to the data set as an adjustment coefficient to compute adjusted estimated-discharge values for drainage basins with areas underlain by carbonate rocks (see table 1). The standard deviation of the 13-station data-set ratios $\left(\mathrm{Q}_{\text {obs }}{ }^{\prime} \mathrm{Q}_{\text {pred }}\right)$ about the mean ratio (in $\log$ units, converted to percent in table 1) is indicative of the accuracy of the discharge estimates adjusted for area underlain by carbonate rocks in the same way as the standard error of estimate of a regression equation is indicative of the accuracy of discharge estimates made by the regression equation.

Plots of the ratios $\left(\mathrm{Q}_{\mathrm{obs}} / \mathrm{Q}_{\mathrm{pred}}\right)$, with the percentage of basin underlain by carbonate rocks were examined for trends. For example, figure 3 shows the relation between the ratios and the percentage of the basin underlain by carbonate rocks for the 


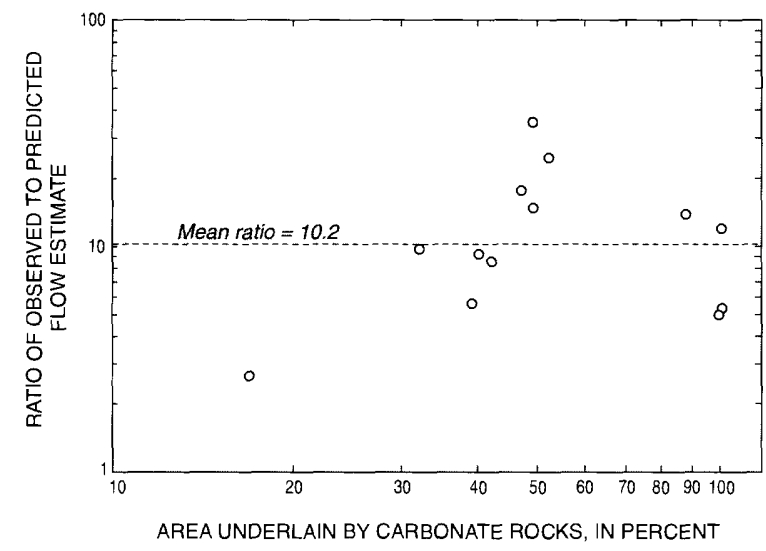

Figure 3. Relation of area underlain by carbonate rocks to ratios of observed to predicted 7-day, 10-year low-flow estimates in western region of Maryland.

7-day, 10-year low flows. For all low-flow characteristics, scatter appeared to be essentially random for areas underlain by carbonate rocks values from 40 to 100 percent, assuming, in the absence of any evidence to the contrary, that random variability is responsible for the largest ratio (residual) values plotting at around 50-percent area underlain by carbonate rocks. Therefore, the mean ratios based on the data from the 13 stations with some area underlain by carbonate rocks are considered to be reasonable coefficients with which to adjust discharge estimates for areas underlain by carbonate rocks ranging from 40 to 100 percent. Adjustment coefficients (mean ratios) and corresponding standard deviations are given in table 1 .

For a site where the area underlain by carbonate rocks is less than 40 percent of the basin area, an adjusted low-flow estimate may be determined by interpolation by adjusting the $\mathrm{Q}_{\text {obs }} / \mathrm{Q}_{\text {pred }}$ ratio (coefficient) to be applied to the discharge computed by the western region estimation equation. The adjusted coefficient should be determined by arithmetic linear interpolation as described earlier in the section "Sites in Western Region." This arithmetic-linear interpolation is recommended for the area underlain by carbonate rocks where adjustments in the 0 - to 40 -percent range provide a reasonable transition and where there are insufficient data available in this range to justify or support developing a more sophisticated method.

The adjustment coefficients given in table 1 and the arithmetic-linear interpolation method previously described may be used to adjust low-flow characteristics for basins in the western region with surficial carbonate rocks in Washington and Frederick Counties. Maps included with Maryland Geological Survey publications by Duigon and Dine (1987 and 1991) may be used to determine the percentage of area underlain by carbonate rocks for the selected drainage basins. It is reasonable and conservative to assume that the standard deviations given in table 1 are indicative of the accuracy of estimates based on those coefficients.

Residuals of low-flow discharge estimates (for $7 Q_{10}$ ) made from equations adjusted for areas underlain by carbonate rocks were plotted and examined for areal bias. No apparent bias was found.

Two relatively new and promising regression techniques were investigated for possible application in developing low-flow estimation equations that could deal more effectively (than the generalized least-squares or ordinary least-squares regression techniques) with regions having zero-discharge low flows at some of their gaging stations. The new techniques considered were censored regression analysis and logistic regression analysis, both of which theoretically could obviate the need for adding constants to the dependent variables in order to deal with zero flow.

Neither technique was suitable for use with the at-site low flows representing the study area. To be effective, the logistic regression technique requires considerably more zero-flow data points than were available, because the technique needs to make regression computations on a subset (of zeroflow gaging stations only) large enough to be truly representative of the physiographic variability of a region. These regression computations are necessary in order to estimate the probability of a zero $\mathrm{N}$-day low flow being an annual minimum. The 
censored regression technique had not been made sufficiently operational (for the type of hydrologic analysis needed) in time to be utilized for this study.

\section{Distance-Weighted Average Analysis}

The southern region (Coastal Plain west of Chesapeake Bay) could not be modeled by multiple-regression analysis. The GLS regression technique was applied but there were no basin characteristics determined to be significant at the 90 -percent level in this region.

Without a suitable regression model, other transfer methods were considered in an attempt to find an acceptable method for estimating low-flow characteristics in the southern region. A method for transferring an average of low-flow values from nearby gaging stations (inversely weighted by the distance from the selected site) was chosen and tested.

To use the distance-weighted average method, the center of the selected drainage basin is first determined. Next, from two to four of the nearest, and physiographically most similar, gaged basins (pl. 1) are selected. Distances are measured from the center of the selected basin (plotted on a map) to the centers of the selected nearby gaged (index) basins (see table 2), also plotted on the map. The low-flow discharge desired $\left(7 Q_{10}\right.$, for example) is reduced to a unit value (discharge per unit area) at each of the selected gaging stations and the average is determined for these unit values inversely weighted by the distances from the ungaged basin center. That average is multiplied by the drainage area at the selected ungaged basin and the result is used as the final estimated discharge. The equation for this method (eq. 55) is presented in the section "Sites in Southern Region." The number of index stations to be used is arbitrarily constrained to two to four to keep the method simple and to encourage use of only stations considered to have similar characteristics.

One other criterion that was followed in selecting the index stations to be used in developing and testing the estimation method was that the angle between the basin centers of any two index stations (when measured from the center of the ungaged basin) was required to exceed 30 degrees (an arbitrary, but considered reasonable limit) before both index stations were included. It is recommended that this criterion be used to limit use of gaged basins that, when viewed from the selected ungaged site, are located in the same direction and at a greater distance than gaged basins already being used as index stations.

In order to obtain an indication of the accuracy of the above estimation method for the southern region, $7 Q_{2}$ and $7 Q_{10}$ low-flow characteristics were estimated using the method at each of nine of the gaged index sites. The nine selected test sites were chosen such that there were minimal intercorrelations between the test sites and any of the index sites appropriate for use in the estimation equation. From two to four of the index sites were used with the estimation equation at each test site in the same manner as previously recommended. The estimated values were compared with at-site values computed from the streamflow record at the gaging stations and the standard deviation and mean of the residuals (at-site values minus estimated values) were determined in logarithmic units for this data set. In order to compute and compare residuals in logarithmic units for the $7 \mathrm{Q}_{10}$ computations (to avoid the problem of the log of zero being undefined), a constant of 0.1 was added to at-site values in the $7 Q_{10}$ and $7 Q_{2}$ data sets as previously indicated. The constant was consequently implicit in the computed values. The statistics for the southern region test set using the distance-weighted average method showed that the method provides a reasonable estimate of the low-flow characteristics.

The areal distribution of the residuals from using the distance-weighted average method was examined for bias by plotting the residuals for the gaging stations on a map. There was no apparent areal bias. For convenience in using the distanceweighted average equation (eq. 55), coordinates of the approximate centers of the drainage basins are given in table 2 .

Because there are no gaging stations in the southern region north of the Patapsco River at which to verify the estimation method, proper application of the method north of the river cannot be assumed. The part of the southern region north of 
the river in the Coastal Plain Province, however, is narrow and the eastern-Piedmont region equations apply to most of the drainage area contributing to most of the streams in this subregion. Results from the eastern-Piedmont region equation for a given stream at the Piedmont region boundary can probably be extrapolated by drainage-area ratio to any point in the northern part of the southern region with little loss of accuracy.

\section{Estimation Methods for Ungaged Sites on Gaged Streams}

The method presented earlier in this report for estimating low flows at ungaged sites on gaged streams is intended to replace the method reported by Carpenter (1983). Carpenter's method was found to give inconsistent results under some circumstances. More specifically, there was a poss1bility of a discontinuity in a progression of estimates moving upstream or downstream in the vicinity of a gaging station. There could be a problem when there is a large disparity between the value computed from station records and the value computed from a regional estimation equation.

For the reasons given, a new method for transferring estimates of low flows upstream or downstream from a gaging station has been developed on the basis of a few basic assumptions. The primary assumption is that the best estimate of a low flow at an ungaged site can be made by first estimating the discharge from an appropriate regional estimation equation, and then adjusting the result to reflect available information at the gaging station nearby on the same stream. A secondary assumption is that the at-site value (based on frequency analysis of station records) is the best estimate of a low-flow characteristic at a gaging station. This assumption is not essential to the new transfer method.

\section{Sites Upstream from Gaging Stations}

The transfer equation for estimating low flows upstream from gaging stations is based on one additional assumption also, that the difference between an at-site flow characteristic (based on the station record) and the corresponding estimated flow characteristic (based on the regional equation) at a gaging station is affected equally by all parts of the drainage basin upstream (in the absence of field information). For example, if the increment of flow, $\Delta \mathrm{Q}$ (which is $\mathrm{Q}_{\text {obs }}$ minus $\mathrm{Q}_{\text {est }}$ ) is $10 \mathrm{ft}^{3} / \mathrm{s}$ at a gaging station, then the incremental accretion rate, per unit area, is assumed to be $10 \mathrm{ft}^{3} / \mathrm{s}$ divided by the total upstream drainage area (for example, $\left.40 \mathrm{mi}^{2}\right)$, or $0.25\left(\mathrm{ft}^{3} / \mathrm{s}\right) \mathrm{mi}^{2}$ throughout the entire upstream basin. Using the same example, the older transfer method (Carpenter, 1983) would have resulted in an increment of $0.0 \mathrm{ft}^{3} / \mathrm{s}$ from the upstream half of the gaged basin, and an increment of $10 \mathrm{ft}^{3} / \mathrm{s}$ from the downstream half, immediately upstream from the gaging station.

The discharge for a selected site upstream from a gaging station (that is, where the $R_{A}$ value is between 0.0 and 1.0 ) is computed by the equation:

$$
\mathrm{Q}_{\mathrm{f}}=\mathrm{Q}_{\mathrm{u}}\left[\frac{\mathrm{Q}_{\mathrm{o}}}{\mathrm{Q}_{\mathrm{e}}}\right]
$$

where terms (including $\mathrm{R}_{\mathrm{A}}$ ) are defined earlier.

This equation is a mathematical representation including the above assumptions. Without additional information about the basin, these assumptions appear to be reasonable. These assumptions and the corresponding equation also eliminate the undesirable possibility of computing unrealistic discharge estimates that reflect a losing or rapidly gaining stream, in the vicinity of the gaging station.

\section{Sites Downstream from Gaging Stations}

The transfer equations for estimating low flows downstream from a gaging station are based on an additional assumption in addition to the two primary assumptions described previously. The additional assumption is that the difference between the at-site flow characteristics (based on station records) and the estimated flow characteristics (based on regional equations) at the gaging station reflects the effect of upstream conditions that is expected to persist to some extent downstream, though gradually diminishing. The downstream transfer equations have one further assumption, 
that the increment of upstream flow $\left(Q_{\text {obs }}\right.$ minus $\left.\mathrm{Q}_{\text {est }}\right)$ apparent at the gaging station continues downstream essentially undiminished (is not arbitrarily removed from the system) to the mouth of the stream.

The assumed persistent affect of upstream flow conditions on the downstream low-flow characteristics is based on the probability that basin and geologic characteristics will be similar nearby upstream and downstream from any given point. The incremental rate (reflecting the conditions upstream) is assumed to diminish linearly from

$$
\left[\frac{Q_{0}-Q_{e}}{A_{g}}\right]
$$

(terms defined earlier) at the gage to zero at some point downstream (arbitrarily chosen to be where the additional increment of drainage area equals $A_{g}$ ). The total incremental flow accumulated at the point $A_{g}$ downstream is then assumed to stay in the stream and continue to flow downstream to the mouth, but without any further accretion.

The discharge for a selected site downstream from a gaging station (that is, where $R_{A}>1.0$ ) is, therefore, computed as follows:

for $1.0 \leq R_{A} \leq 2.0$

$$
Q_{f}=Q_{u}+R_{A}\left(\Delta Q_{g}\right)\left(1.25-0.25 R_{A}\right)
$$

and for $R_{A}>2.0$

$$
\mathrm{Q}_{\mathrm{f}}=\mathrm{Q}_{\mathrm{u}}+1.5\left(\Delta \mathrm{Q}_{\mathrm{g}}\right)
$$

where terms are defined earlier.

These equations are mathematical representations of the low-flow response-pattern assumptions above. In the absence of additional information about a selected basin, these assumptions are reasonable. Also, estimates made by using these equations are supported by verification tests discussed in the following subsection.

\section{Evaluation of Method}

The new method presented in this report for estimating low flows at ungaged sites upstream and downstream from gaging stations was developed and has been tested to assure consistent results under varying conditions. In addition, the new method and Carpenter's (1983) transfer method were tested for accuracy of results on 23 paired gaging stations (two stations on the same stream) selected randomly from Pennsylvania, New York, Maryland, West Virginia, and Kentucky, where regionalized multiple-regression estimation equations were available. Paired sites only in Maryland and Delaware were not used because no paired stations were available that met the desired criteria described below.

Paired stations were selected for verification testing only if relatively long periods of unregulated record (usually over 20 years at each station) were available and only if the "paired" periods of record indicated reasonably good temporal correspondence. Also, stations were included only if their low flows exceeded $0.05 \mathrm{ft}^{3} / \mathrm{s}$. Less than $0.05 \mathrm{ft}^{3} / \mathrm{s}$ was considered as zero flow. The paired stations that were used are given by State in table 7 and are shown in figures 4,5 , and 6.

The new upstream-downstream transfer method for making discharge estimates at ungaged sites downstream from gaging stations was applied to estimate $7 Q_{2}$ and $7 Q_{10}$ values at the downstream station of each of the 23 pairs of "test" stations, and residuals were determined in logarithmic units (atsite values from streamflow records minus predicted values from the upstream-downstream transfer equations). One data pair was excluded (stations 03300400 and 03301000 ) from the $7 Q_{10}$ verification analysis because of discharge values less than $0.05 \mathrm{ft}^{3} / \mathrm{s}$. The $7 \mathrm{Q}_{2}$ and $7 \mathrm{Q}_{10}$ sets of residuals were combined and the standard deviation and mean for the combined sets ( 45 observations) were determined and are given, in percent, in table 8. The test was repeated using the new transfer method to make discharge estimates at ungaged sites upstream from gaging stations. The resulting $7 Q_{2}$ and $7 Q_{10}$ sets of residuals were also combined and statistics for the combined sets were computed and are included in table 8 . The test was then repeated with the previously used upstream- 
Table 7. Streamflow-gaging-station pairs used in analysis of accuracy of low-flow estimates at ungaged sites on gaged streams

[Climatic year, 12-month period from April 1 through March 31]

\begin{tabular}{|c|c|c|c|}
\hline $\begin{array}{l}\text { Station } \\
\text { no. }\end{array}$ & State & $\begin{array}{l}\text { Period of } \\
\text { record used } \\
\text { (climatic years) }\end{array}$ & $\begin{array}{l}\text { Drainage area } \\
\text { (square miles) }\end{array}$ \\
\hline $\begin{array}{l}01440400 \\
01442500\end{array}$ & $\begin{array}{l}\text { Pennsylvania } \\
\text { Pennsylvania }\end{array}$ & $\begin{array}{l}1958-89 \\
1951-89\end{array}$ & $\begin{array}{l}65.9 \\
259\end{array}$ \\
\hline $\begin{array}{l}01448000 \\
01453000\end{array}$ & $\begin{array}{l}\text { Pennsylvania } \\
\text { Pennsylvania }\end{array}$ & $\begin{array}{l}1917-58 \\
1917-58\end{array}$ & $\begin{array}{r}322 \\
1,279\end{array}$ \\
\hline $\begin{array}{l}01480300 \\
01480500\end{array}$ & $\begin{array}{l}\text { Pennsylvania } \\
\text { Pennsylvania }\end{array}$ & $\begin{array}{l}1961-89 \\
1970-89\end{array}$ & $\begin{array}{l}18.7 \\
45.8\end{array}$ \\
\hline $\begin{array}{l}01480500 \\
01480617\end{array}$ & $\begin{array}{l}\text { Pennsylvania } \\
\text { Pennsylvania }\end{array}$ & $\begin{array}{l}1970-89 \\
1970-89\end{array}$ & $\begin{array}{l}45.8 \\
55\end{array}$ \\
\hline $\begin{array}{l}01518000 \\
01520500\end{array}$ & $\begin{array}{l}\text { Pennsylvania } \\
\text { New York }\end{array}$ & $\begin{array}{l}1939-75 \\
1930-75\end{array}$ & $\begin{array}{l}282 \\
770\end{array}$ \\
\hline $\begin{array}{l}01520500 \\
01526500\end{array}$ & $\begin{array}{l}\text { New York } \\
\text { New York }\end{array}$ & $\begin{array}{l}1930-75 \\
1930-75\end{array}$ & $\begin{array}{r}770 \\
1,370\end{array}$ \\
\hline $\begin{array}{l}01534500 \\
01536000\end{array}$ & $\begin{array}{l}\text { Pennsylvania } \\
\text { Pennsylvania }\end{array}$ & $\begin{array}{l}1940-59 \\
1940-59\end{array}$ & $\begin{array}{l}108 \\
332\end{array}$ \\
\hline $\begin{array}{l}01543000 \\
01543500\end{array}$ & $\begin{array}{l}\text { Pennsylvania } \\
\text { Pennsylvania }\end{array}$ & $\begin{array}{l}1939-89 \\
1939-89\end{array}$ & $\begin{array}{l}272 \\
685\end{array}$ \\
\hline $\begin{array}{l}01548500 \\
01549700\end{array}$ & $\begin{array}{l}\text { Pennsylvania } \\
\text { Pennsylvania }\end{array}$ & $\begin{array}{l}1958-89 \\
1958-89\end{array}$ & $\begin{array}{l}604 \\
944\end{array}$ \\
\hline $\begin{array}{l}03010500 \\
03011020\end{array}$ & $\begin{array}{l}\text { Pennsylvania } \\
\text { New York }\end{array}$ & $\begin{array}{l}1940-89 \\
1940-89\end{array}$ & $\begin{array}{r}550 \\
1,608\end{array}$ \\
\hline $\begin{array}{l}03078000 \\
03079000\end{array}$ & $\begin{array}{l}\text { Maryland } \\
\text { Pennsylvania }\end{array}$ & $\begin{array}{l}1948-89 \\
1948-89\end{array}$ & $\begin{array}{l}62.5 \\
382\end{array}$ \\
\hline $\begin{array}{l}01605500 \\
01606500\end{array}$ & $\begin{array}{l}\text { West Virginia } \\
\text { West Virginia }\end{array}$ & $\begin{array}{l}1940-69,1977-83 \\
1929-83\end{array}$ & $\begin{array}{l}182 \\
642\end{array}$ \\
\hline $\begin{array}{l}01607500 \\
01608000\end{array}$ & $\begin{array}{l}\text { West Virginia } \\
\text { West Virginia }\end{array}$ & $\begin{array}{l}1944-83 \\
1929-35,1939-83\end{array}$ & $\begin{array}{l}102 \\
283\end{array}$ \\
\hline $\begin{array}{l}03050000 \\
03050500\end{array}$ & $\begin{array}{l}\text { West Virginia } \\
\text { West Virginia }\end{array}$ & $\begin{array}{l}1916-75 \\
1945-83\end{array}$ & $\begin{array}{l}187 \\
272\end{array}$ \\
\hline $\begin{array}{l}03050500 \\
03051000\end{array}$ & $\begin{array}{l}\text { West Virginia } \\
\text { West Virginia }\end{array}$ & $\begin{array}{l}1945-83 \\
1908-83\end{array}$ & $\begin{array}{l}272 \\
408\end{array}$ \\
\hline $\begin{array}{l}03058500 \\
03061000\end{array}$ & $\begin{array}{l}\text { West Virginia } \\
\text { West Virginia }\end{array}$ & $\begin{array}{l}1916-83 \\
1908-16,1933-83\end{array}$ & $\begin{array}{l}181 \\
759\end{array}$ \\
\hline $\begin{array}{l}03180500 \\
03182500\end{array}$ & $\begin{array}{l}\text { West Virginia } \\
\text { West Virginia }\end{array}$ & $\begin{array}{l}1944-83 \\
1930-83\end{array}$ & $\begin{array}{l}133 \\
540\end{array}$ \\
\hline $\begin{array}{l}03187000 \\
03189500\end{array}$ & $\begin{array}{l}\text { West Virginia } \\
\text { West Virginia }\end{array}$ & $\begin{array}{l}1910-16,1930-75 \\
1909-16,1929-65\end{array}$ & $\begin{array}{l}236 \\
680\end{array}$ \\
\hline $\begin{array}{l}03195000 \\
03195500\end{array}$ & $\begin{array}{l}\text { West Virginia } \\
\text { West Virginia }\end{array}$ & $\begin{array}{l}1935-63 \\
1938-60\end{array}$ & $\begin{array}{l}281 \\
542\end{array}$ \\
\hline $\begin{array}{l}03300400 \\
03301000\end{array}$ & $\begin{array}{l}\text { Kentucky } \\
\text { Kentucky }\end{array}$ & $\begin{array}{l}1972-87 \\
1939-74\end{array}$ & $\begin{array}{l}436 \\
669\end{array}$ \\
\hline $\begin{array}{l}03307000 \\
03307100\end{array}$ & $\begin{array}{l}\text { Kentucky } \\
\text { Kentucky }\end{array}$ & $\begin{array}{l}1940-87 \\
1965-75\end{array}$ & $\begin{array}{l}188 \\
265\end{array}$ \\
\hline $\begin{array}{l}03401000 \\
03403000\end{array}$ & $\begin{array}{l}\text { Kentucky } \\
\text { Kentucky }\end{array}$ & $\begin{array}{l}1940-87 \\
1938-75,1980-87\end{array}$ & $\begin{array}{l}374 \\
809\end{array}$ \\
\hline $\begin{array}{l}03403000 \\
03403500\end{array}$ & $\begin{array}{l}\text { Kentucky } \\
\text { Kentucky }\end{array}$ & $\begin{array}{l}1938-75.1980-87 \\
1923-31,1948-87\end{array}$ & $\begin{array}{l}809 \\
960\end{array}$ \\
\hline
\end{tabular}




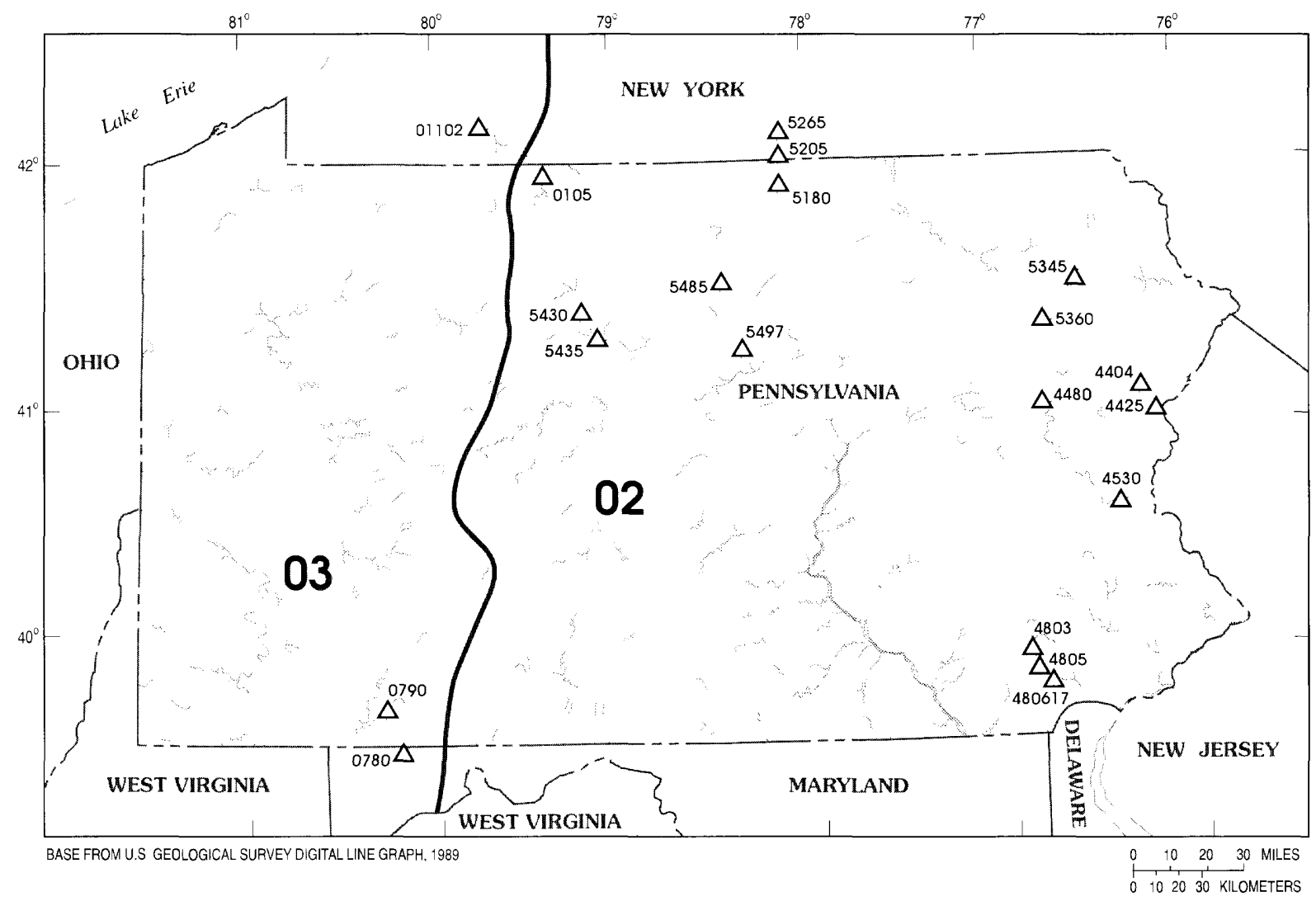

EXPLANATION

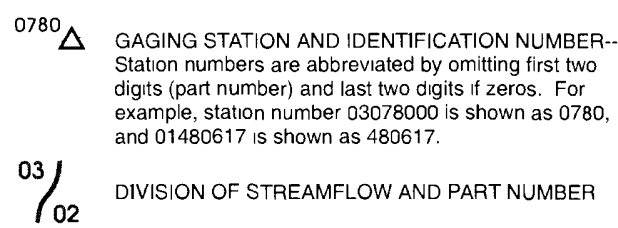

Figure 4. Location of paired streamflow-gaging stations in Pennsylvania, Maryland, and New York.

downstream transfer method (Carpenter, 1983) applied to estimate $7 Q_{2}$ and $7 Q_{10}$ values upstream and downstream from gaging stations. Results were combined and included in table 8 for comparison with the new transfer method.

The test was also repeated using only the results of the regional regression estimation equation as low-flow estimates for the ungaged sites, without attempting any adjustment based on the nearby gaging-station information. The differ- ences between the statistics of the residuals from the upstream-downstream transfer methods and those from the basic, unadjusted, regional estimation equations (table 8) provide an indication of the improvement in low-flow estimates to be expected by using either of the transfer methods. The mean of the residuals statistic is an indicator of the potential bias of the discharge estimates by the various methods. For example, in table 8, the lowflow values at ungaged sites upstream from gaging stations were on the average 10 percent greater 


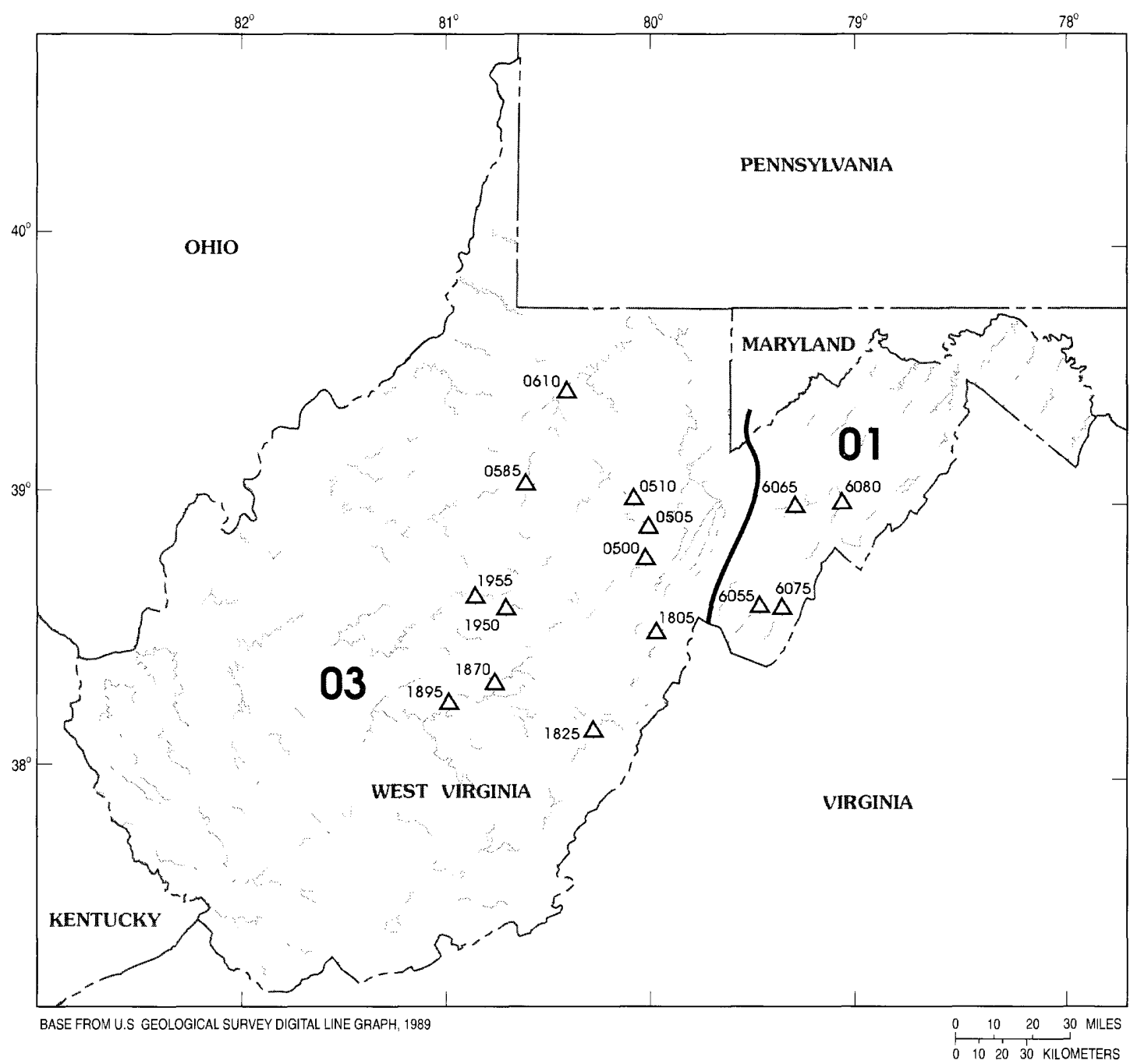

EXPLANATION

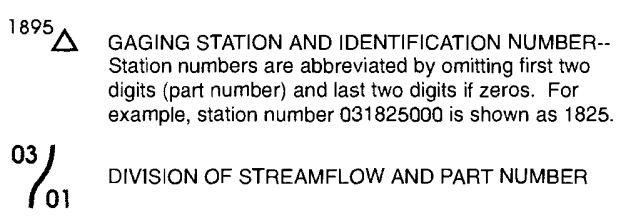

Figure 5. Location of paired streamflow-gaging stations in West Virginia.

than the predicted values, when estimated by the old transfer method (Carpenter, 1983). There appears to be less bias in the new transfer method than either the older method or the unadjusted regional equation approach.

The method for transferring low flows upstream and downstream from gaging stations was tested primarily on relatively large drainage basins (larger than $100 \mathrm{mi}^{2}$ ). It is reasonable to assume that small areas, in general, are geologi- cally and physiographically more homogeneous than large areas. The new transfer method is, therefore, expected to be even more accurate than the old method when applied to smaller drainage areas. This is because the new method assumes more, and is more sensitive to, uniformity in basinwide response than the old method. For example, the new method assumes that whatever hydrologic factors have been affecting the variation in flow patterns upstream from a gage will continue to similarly affect the variation in flow patterns 


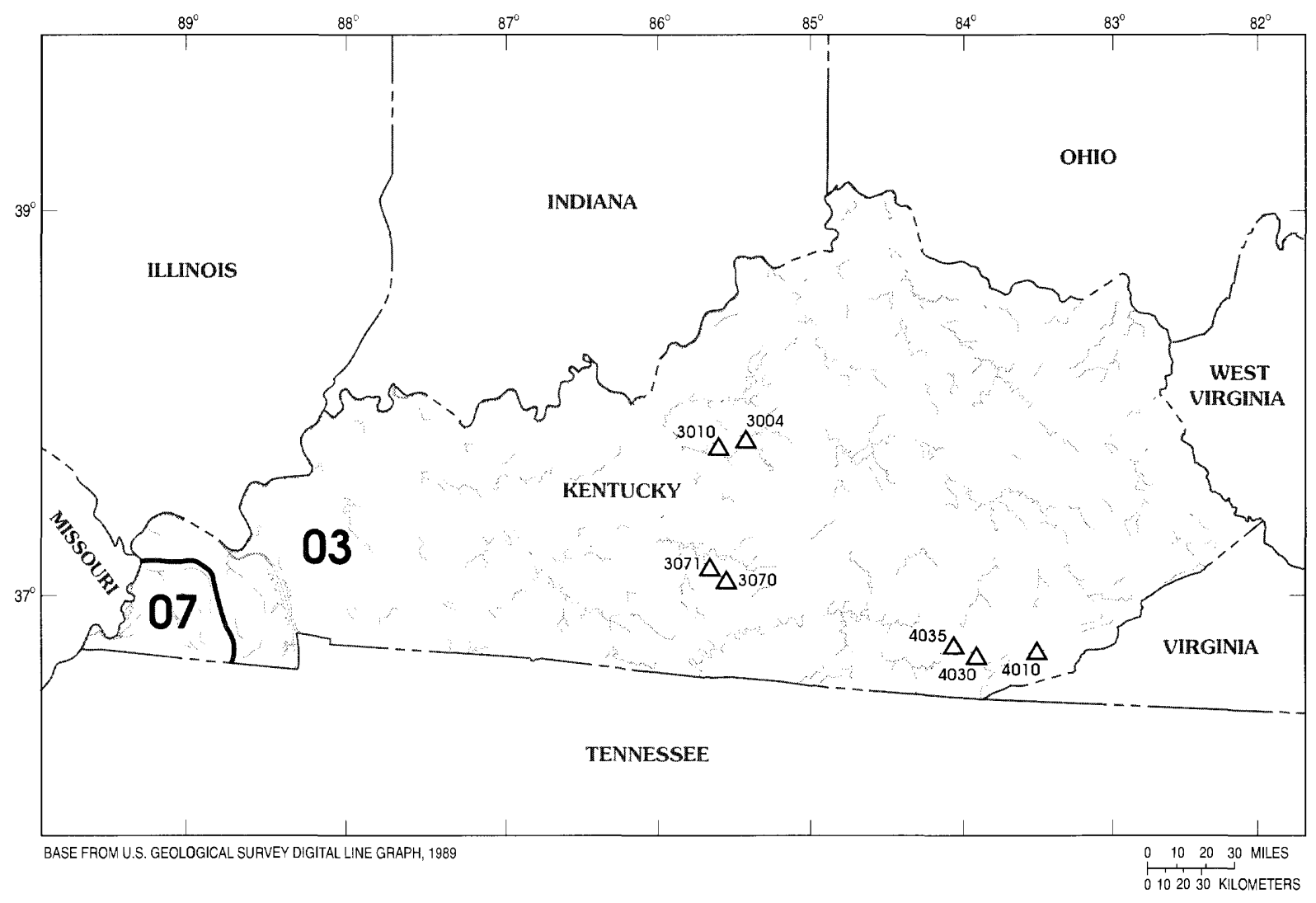

EXPLANATION

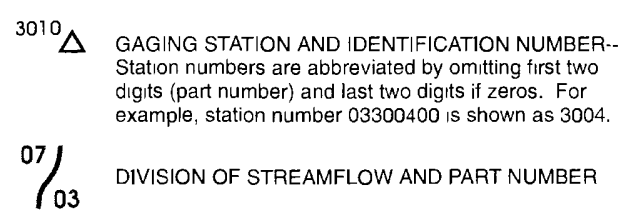

Figure 6. Location of paired streamflow-gaging stations in Kentucky.

downstream from the gage, though gradually diminishing (but not reversing) as the distance downstream increases. This assumption differs with the method (believed to have widespread use with only minor variations) which, when continuing downstream from a gaging station systematically removes any increment of flow (positive or negative) that had accrued upstream from the gaging station $\left(\mathrm{Q}_{\mathrm{obs}}-\mathrm{Q}_{\mathrm{est}}\right.$ at the gaging station).

The somewhat radical approach used in the new method to estimate low flows at ungaged sites upstream from gaging stations could be modified. This approach, in effect, has the $\Delta Q_{g}$ (defined elsewhere) at the gaging station affecting estimates at the extreme headwaters to the same extent (in the same ratio) as it affects estimates immediately upstream from the gage. This approach, however, cannot be made more conservative without potentially jeopardizing the assured continuity built into the method; that is, that transferred low-flow estimates will consistently increase going downstream, providing the results of the regional regression estimation equation are the same. 
Table 8. Standard deviations and means of residuals from low-flow estimates at ungaged sites on gaged streams in Pennsylvania, New York, Maryland, West Virginia, and Kentucky

[Data given are for 7-day, 2-year, and 10-year results combined]

Upstream-downstream transfer method

\begin{tabular}{|c|c|c|c|}
\hline Statistic & $\begin{array}{l}\text { Carpenter method } \\
\text { (1983) }\end{array}$ & $\begin{array}{l}\text { Revised method } \\
\text { (this report) }\end{array}$ & $\begin{array}{l}\text { Regional } \\
\text { equations }\end{array}$ \\
\hline \multicolumn{4}{|c|}{ Downstream from gaging station } \\
\hline $\begin{array}{l}\text { Standard deviation } \\
\text { of residuals } \\
\text { (in percent) }\end{array}$ & 46 & 36 & 48 \\
\hline $\begin{array}{l}\text { Mean of residuals } \\
\text { (in percent) }\end{array}$ & 5 & -3 & 6 \\
\hline \multicolumn{4}{|c|}{ Upstream from gaging station } \\
\hline $\begin{array}{l}\text { Standard deviation } \\
\text { of residuals } \\
\text { (in percent) }\end{array}$ & 36 & 37 & 42 \\
\hline $\begin{array}{l}\text { Mean of residuals } \\
\text { (in percent) }\end{array}$ & 10 & 8 & 15 \\
\hline
\end{tabular}

\section{ESTIMATION EXAMPLES}

In this section, step-by-step examples are given showing how to compute estimated values for low-flow characteristics. The examples are based on the methods described in the section "Low-Flow Characteristics at Ungaged Locations." Basin-characteristic values needed for the estimation equations could be determined as described in table 9.

\section{Ungaged Site on Ungaged Stream}

Problem: Estimate the 7-day, 2-year low-flow discharge of Radcliffe Creek at State Highway 20, at Chestertown, Md.
1. Determine in which region the drainage basin is located (pl. 1) to determine which set of equations (1-55) and which basin characteristics apply;

region: Eastern Shore region.

2. Determine drainage area. Outline the drainage basin upstream from State Highway 20 on best available topographic map(s) and planimeter (or digitize) area;

$\mathrm{A}=4.30 \mathrm{mi}^{2}$. 
Table 9. Basin characteristics used in equations for estimation of low-flow characteristics of streams in Maryland and Delaware

1. Drainage area (A), in square miles: Planimeter (or digitize) from best available topographic maps.

2. Forest cover (F), in percent: Determine from topographic maps as follows: The part of the basin covered by forests (shaded green on U.S. Geological Survey maps) as determined by the grid method (a minimum of 100-grid intersections is recommended). Count the number of grid intersections in the green; divide by the total number of grid intersections within the drainage basin boundary; multiply the result by 100 .

3. Type A soils $\left(\mathbf{S}_{a}\right)$, classified as having "low runoff potential." Determine $S_{a}$ in percent from soils maps (pls. 2-10) as follows: Planimeter (or digitize) area of the drainage basin covered by type A soil. Express that area in percent of the total drainage area.

4. Type D soils $\left(\mathbf{S}_{d}\right)$, classified as having "high runoff potential." Determine $S_{d}$ in percent from soils maps (pls. 2-10) as follows: Planimeter (or digitize) area of the drainage basin covered by type D soil. Express that area in percent of the total drainage area.

5. Mean-annual precipitation (P), in inches: Determine from the precipitation map (fig. 2 ) as follows: Outline drainage basin on map. Use precipitation value weighted with respect to distance to center of basin from nearest 1solines.

3. Determine forest cover. On the topographic map, measure the forested area within the drainage basin (shaded green on U.S.

$\mathrm{S}_{\mathrm{a}}=\left(\frac{0}{4.30}\right) 100=0$ percent.

Geological Survey maps) by grid method; area $=0.330 \mathrm{mi}^{2}$.

$F=\left(\frac{0.330}{4.30}\right) 100=8$ percent

5. Determine type D soils. Planimeter (or digitize) the area of type $\mathrm{D}$ soil within the drainage basin on soils map (pl. 5); area = $0.557 \mathrm{mi}^{2}$.

4. Determine type A soils. Outline the drainage $S_{d}=\left(\frac{0.557}{4.30}\right) 100=13$ percent. basin on soils map (pl. 5). Planimeter (or digitize) the area of type A soil; area $=0 \mathrm{mi}^{2}$.

6. Compute the 7-day, 2-year low-flow discharge. Using equation 1 (Eastern Shore region), 
$7 \mathrm{Q}_{2}+0.2=0.396 \mathrm{~A}^{0.916}(\mathrm{~F}+10)^{-0.433}\left(\mathrm{~S}_{\mathrm{a}}+10\right)^{0.559}\left(\mathrm{~S}_{\mathrm{d}}+10\right)^{-0.556}$

By substitution,

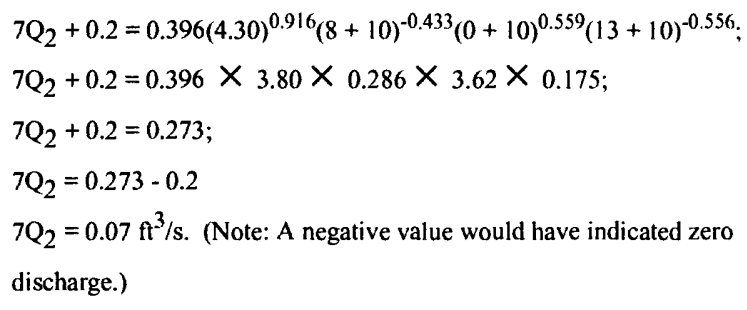

\section{Ungaged Site on Gaged Stream}

Problem: Estimate the 7-day, 10-year low-flow discharge of Deer Creek at U.S.

Highway 1, near Bel Air, Md., about 11 mi downstream from gaging station 01580000, Deer Creek at Rocks, Md.

1. Determine in which region the drainage basin is located (pl. 1) to determine which set of equations (1-55) and which basin characteristics apply;

region: subregion $\mathrm{C}$ of eastern-Piedmont region.

2. Determine drainage area for Deer Creek at U.S. Highway 1 (ungaged site). Outline the drainage basin upstream from U.S. Highway 1 on best available topographic map(s) and planimeter (or digitize) area;

$$
A_{u}=125 \mathrm{mi}^{2}
$$

3. Obtain drainage area for Deer Creek at Rocks (gaging station 01580000) from table 10;

$$
A_{g}=94.4 \mathrm{mi}^{2} \text {. }
$$

4. Obtain 7-day, 10-year discharge for Deer Creek at the gaging station from table 11 ;

$\mathrm{Q}_{\mathrm{o}}=25.4 \mathrm{ft}^{3} / \mathrm{s}$.
5. Compute the estimated 7-day, 10-year discharge for Deer Creek at the gaging station by the regional estimation equation. Using equation 29 (subregion $\mathrm{C}$ of easternPiedmont region),

$\mathrm{Q}_{\mathrm{e}}=0.164 \mathrm{~A}^{1.092}$.

By substitution,

$\mathrm{Q}_{\mathrm{e}}=0.164(94.4)^{1.092}$;

$\mathrm{Q}_{\mathrm{e}}=0.164 \times 143$;

$\mathrm{Q}_{\mathrm{e}}=23.5 \mathrm{ft}^{3} / \mathrm{s}$.

6. Compute the estimated 7-day, 10-year discharge for Deer Creek at the selected ungaged site by the regional estimation equation. Using equation 29 ,

$\mathrm{Q}_{\mathrm{u}}=0.164 \mathrm{~A}^{1.092}$.

By substitution,

$\mathrm{Q}_{\mathrm{u}}=0.164(125)^{1.092}$;

$\mathrm{Q}_{\mathrm{u}}=0.164 \times 195$;

$\mathrm{Q}_{\mathrm{u}}=32.0 \mathrm{ft}^{3} / \mathrm{s}$.

7. Determine the difference between the at-site and the estimated discharge for Deer Creek at the gaging station. Using equation 60 ,

$$
\Delta Q_{g}=Q_{o}-Q_{e}
$$

By substitution,

$$
\begin{gathered}
\Delta Q_{g}=25.4-23.5 ; \\
\Delta Q_{g}=1.9 \mathrm{ft}^{3} / \mathrm{s} .
\end{gathered}
$$

8. Determine the ratio of the drainage area at the ungaged site to the drainage area at the gaging station. Using equation 59 ,

$$
\mathrm{R}_{\mathrm{A}}=\frac{\mathrm{A}_{\mathrm{u}}}{\mathrm{A}_{\mathrm{g}}}
$$


By substitution,

$$
\begin{aligned}
& \mathrm{R}_{\mathrm{A}}=\frac{125}{94.4} \\
& \mathrm{R}_{\mathrm{A}}=1.32 .
\end{aligned}
$$

9. Based on the $R_{A}$ value being between 1.0 and 2.0 , the final adjusted 7-day, 10-year lowflow discharge at the ungaged site is determined by equation 57 . Using equation 57 ,

$$
\mathrm{Q}_{\mathrm{f}}=\mathrm{Q}_{\mathrm{u}}+\mathrm{R}_{\mathrm{A}}\left(\Delta \mathrm{Q}_{\mathrm{g}}\right)\left(1.25-0.25 \mathrm{R}_{\mathrm{A}}\right)
$$

$$
\begin{aligned}
\text { By substitution, } \\
\mathrm{Q}_{\mathrm{f}}=32.0+1.32 \times 1.9(1.25-0.25 \times 1.32) \\
\mathrm{Q}_{\mathrm{f}}=32.0+2.51(1.25-0.33) \\
\mathrm{Q}_{\mathrm{f}}=32.0+2.51 \times 0.92 \\
\mathrm{Q}_{\mathrm{f}}=32.0+2.31 \\
\mathrm{Q}_{\mathrm{f}}=34.3 \mathrm{ft}^{3} / \mathrm{s}
\end{aligned}
$$

\section{SUMMARY}

This report is an update of a 1983 report that presented similar low-flow information in a less comprehensive manner. The earlier report, which described peak-flow and low-flow characteristics, provided the first methods for estimating low-flow characteristics at ungaged sites in Maryland. This report provides more accurate estimation methods for low-flow characteristics with greater areal coverage based on data from substantially more gaging stations and longer streamflow records.

Low-flow characteristics of a verage 7-, 14-, and 30-consecutive-day low flows with recurrence intervals of 2, 10, and 20 years were determined at 94 continuous-record gaging stations and 131 partial-record gaging stations. Streamflow records during unregulated periods were analyzed from streams in Maryland, Delaware, and surrounding States having drainage areas ranging from 2.0 to $875 \mathrm{mi}^{2}$.
Regression equations, based on a generalized least-squares (GLS) regression analyses, were developed to estimate low-flow characteristics at ungaged sites on ungaged streams in three regions. The regions correspond with the Coastal Plain Province east of Chesapeake Bay (Eastern Shore region), the Piedmont Province east of the Monocacy River (eastern-Piedmont region), and the Appalachian Plateaus, Valley and Ridge, Blue Ridge, and Piedmont Provinces west of the Monocacy River (western region). The eastern-Piedmont region was further subdivided into four subregions, each with separate estimation equations. The low-flow discharges estimated from the equation for the western region were adjusted for the effects of carbonate rocks on the low flows. The adjustment method was based on analysis of the residuals of regional estimation equations and the percentage of the basin underlain by carbonate rocks. An equation based on a distance-weighted average of low-flow discharges at nearby gaging stations was developed to estimate low-flow characteristics at ungaged sites on ungaged streams in a fourth region. This region corresponds to the Coastal Plain Province west of the Chesapeake Bay (southern region).

Two methods were developed for estimating low-flow characteristics at ungaged sites on gaged streams. One method estimates low-flow characteristics at ungaged sites by transferring low-flow values upstream or downstream from a gaging station. Another method estimates low-flow characteristics at ungaged sites between gaging stations.

Average standard errors of prediction for the GLS estimation equations, which range from 9 to 84 percent, along with other evaluations of the estimation equation used in the southern region and the transfer methods used on gaged streams, indicate that the methods should give satisfactory results within the range of basin characteristics used in the derivations. However, additional data collection and further analysis is recommended for the southern region where standard deviations of the model residuals were large (for example, 114 percent for 7-day, 2-year, low-flow estimates). 
Carpenter, D. H., 1980, Technique for estimating magnitude and frequency of floods in Maryland: U.S. Geological Survey WaterResources Investigations 80-1016, 79 p. 1983, Characteristics of streamflow in Maryland: Maryland Geological Survey Report of Investigations 35, $237 \mathrm{p}$.

Chatterjee, Samprit, and Price, Bertram, 1977. Regression analysis by example: New York. John Wiley, $228 \mathrm{p}$.

Cushing, E. M., Kantrowitz, I. H., and Taylor, K. R., 1973, Water resources of the Delmarva Peninsula: U.S. Geological Survey Professional Paper $822,58 \mathrm{p}$.

Duigon, M. T., and Dine, J. R., 1987, Water resources of Frederick County, Maryland: Maryland Geological Survey Bulletin 33, $106 \mathrm{p}$.

1991, Water resources of Washington County, Maryland: Maryland Geological Survey Bulletin 36, $109 \mathrm{p}$.

Hardison, C. H., 1969, Accuracy of streamflow characteristics: U.S. Geological Survey Professional Paper 650-D, p. D210-D214. 1971, Prediction error of regression estimates of streamflow characteristics at ungaged sites: U.S. Geological Survey Professional Paper 750-C, p. C228-C236.

Maryland Department of State Planning, [1974], Natural soil group map, [Caroline County, Maryland]: scale 1:63,360. [no date], Natural soil group map, [Cecil County, Maryland]: scale 1:63,360. [no date], Natural soil group map, [Dorchester County, Maryland]: scale $1: 63,360$. 1974, Natural soil group map, [Kent County, Maryland]: scale 1:63,360. 1974, Natural soil group map, [Queen Annes County, Maryland]: scale 1:63,360. 1974, Natural soil group map, [Somerset County, Maryland]: scale 1:63,360. 1974, Natural soil group map, [Talbot County, Maryland]: scale 1:63,360. [no date], Natural soil group map,

[Wicomico County, Maryland]: scale 1:63,360.

[no date], Natural soil group map, [Worcester County, Maryland]: scale 1:63,360.

Maryland Department of State Planning, 1973. Natural soil groups technical report: Maryland Department of State Planning, pub. no. 199. $153 \mathrm{p}$.

Maryland Geological Survey, 1967, Generalized geologic map of Maryland: scale 1:250,000.

Nutter, L. J., 1973, Hydrogeology of the carbonate rocks, Frederick and Hagerstown valleys, Maryland: Maryland Geological Survey Report of Investigations 19,68 p.

Riggs, H. C., 1972, Low-flow investigations: U.S. Geological Survey Techniques of WaterResources Investigations, book 4, chap. B1, $18 \mathrm{p}$.

1973, Regional analyses of streamflow characteristics: U.S. Geological Survey Techniques of Water-Resources Investigations, book 4, chap. B3, 15 p.

Simmons, R. H., and Carpenter, D. H., 1978, Technique for estimating magnitude and frequency of floods in Delaware: U.S. Geological Survey Water-Resources Investigations 78-93, $69 \mathrm{p}$.

Stedinger, J. R., and Thomas, W. O., Jr., 1985, Low-flow frequency estimation using baseflow measurements: U.S. Geological Survey Open-File Report 85-95, 22 p.

Tasker, G. D., 1989, Regionalization of low flow characteristics using logistic and GLS regression, in Kavvas, M.L., ed., New directions for surface water modeling: International Association of Hydrologic Sciences, pub. no. 181, p. 323-331.

Tasker, G. D., and Stedinger, J. R., 1989, An operational GLS model for hydrologic regression: Journal of Hydrology III, p. 361-375.

Thomas, D. M., and Benson, M. A., 1970, Generalization of streamflow characteristics from drainage basin characteristics: U.S. Geological Survey Water-Supply Paper 1975, 55 p. 
U.S. Soil Conservation Service, [1976], Natural soil group map, [Kent County, Delaware]: scale $1: 48,000$.

1976, Natural soil group map, [New Castle County, Delaware]: scale 1:63,360. 1976, Natural soil group map, [Sussex County, Delaware]: scale 1:63,360.

U.S. Weather Bureau, 1959a, Climates of the States, Maryland: U.S. Weather Bureau Climatography of the United States, no. 60-18, $20 \mathrm{p}$. 1959b. Climates of the States, New Jersey: U.S. Weather Bureau Climatography of the United States, no. 60-28, $16 \mathrm{p}$. $1959 \mathrm{c}$, Climates of the States, Virginia:

U.S. Weather Bureau Climatography of the United States, no. $60-44,25$ p. 1960a, Climates of the States, Pennsylvania: U.S. Weather Bureau Climatography of the United States, no. 60-36, 24 p.

$1960 b$, Climates of the States, West Virginia: U.S. Weather Bureau Climatography of the United States, no. 60-46, 16 p.

Vokes, H. E., and Edwards, J. E., Jr., 1974, Geography and geology of Maryland: Maryland Geological Survey Bulletin 19, $242 \mathrm{p}$.

Walker, P. N., 1971, Flow characteristics of Maryland streams: Maryland Geological Survey Report of Investigations 16, $160 \mathrm{p}$. 


\section{GLOSSARY}

Base flow--The contribution of flow in a stream from ground water or spring effluent.

Coefficient of determination $\left(\mathrm{R}^{2}\right)$--Statistical index of the goodness of fit of a curve of relation through a set of data pairs. $R^{2}$ is the proportion (stated as a decimal) of the total scatter of the dependent variable values (in terms of the sum of the squares) that is accounted for by the fitted relation. Coefficients of determination are often used to evaluate linear regression relations.

Cubic foot per second $\left(\mathrm{ft}^{3} / \mathrm{s}\right)-\mathrm{A}$ unit expressing rate of flow; the volume of water passing a point on a stream per unit of time, $1 \mathrm{ft}^{3} / \mathrm{s}=$ 448.8 gallons per minute, is equal to the discharge of a stream of rectangular cross section $1 \mathrm{ft}$ wide and $1 \mathrm{ft}$ deep, flowing at an average velocity of $1 \mathrm{ft} / \mathrm{s}$. It equals $28.32 \mathrm{~L} / \mathrm{s}$ or $0.02832 \mathrm{~m}^{3} / \mathrm{s}$.

Cubic feet per second per square mile $\left[\left(\mathrm{ft}^{3} / \mathrm{s}\right) / \mathrm{mi}^{2}\right]$--The average number of cubic feet per second flowing from each square mile of area drained by a stream, assuming that the runoff is distributed uniformly in time and area. [ $1\left(\mathrm{ft}^{3} / \mathrm{s}\right) / \mathrm{mi}^{2}$ is equivalent to 0.0733 $\left.\left(\mathrm{m}^{3} / \mathrm{s}\right) / \mathrm{km}^{2}\right]$.

\section{Drainage area of a stream at a specific location--} The area, measured in a horizontal plane, bounded by topographic divides. Drainage area is given in square miles $\left(\mathrm{mi}^{2}\right) .\left[1 \mathrm{mi}^{2}\right.$ is equivalent to $2.590 \mathrm{~km}^{2}$ ].

Equivalent years of record--For continuousrecord stations, the number of complete years of streamflow record available. For partialrecord stations, an estimate of statistical equivalence of correlated data to complete years of streamflow record.

Evapotranspiration--The water withdrawn from a land area by evaporation from water surfaces and moist soil, and by transpiration from vegetation.

Gaging station--A particular site on a stream where systematic observations of gage height or discharge are made.

Recurrence interval--As applied to low-flow statistics, recurrence interval is the average number of years within which the streamflow will be less than the given statistic once.

Standard error of estimate--The standard deviation of the estimated values. 


\section{APPENDIX}

\section{Streamflow-Gaging-Station Data}

Streamflow characteristics and basin characteristics along with station coordinates (and other pertinent data for partial-record gaging stations) are presented in tables 10 through 12 for all streamflow-gaging stations included in this report. Data for 94 continuous-record gaging stations are presented in tables 10 and 11 and data for 131 lowflow partial-record gaging stations are presented in table 12. Soil type A and type B characteristics only apply to basins in the Eastern Shore region of the Coastal Plain Province. 
Table 10. Basin characteristics at continuous-record streamflow-gaging stations in Maryland and Delaware

[Latitude and longitude are given in degrees $\left(\right.$ ), minutes ( ), and seconds ("). $\mathrm{mi}^{2}$, square miles; ft/mi, feet per mile; --, value was not determined. Footnotes are found at end of the table]

\begin{tabular}{|c|c|c|c|c|c|c|c|c|c|c|c|}
\hline $\begin{array}{l}\text { Station } \\
\text { no. }\end{array}$ & Latitude & Longitude & $\begin{array}{c}\text { Drainage } \\
\text { area } \\
\left(\mathbf{m i}^{2}\right)\end{array}$ & $\begin{array}{l}\text { Channel } \\
\text { length } \\
\text { (miles) }\end{array}$ & $\begin{array}{c}\text { Channel } \\
\text { slope } \\
(\mathbf{f t} / \mathrm{mi})\end{array}$ & $\begin{array}{l}\text { Drainage } \\
\text { basin } \\
\text { elevation } \\
\text { (feet) }\end{array}$ & $\begin{array}{l}\text { Storage } \\
\text { (percent) }\end{array}$ & $\begin{array}{l}\text { Forest } \\
\text { cover } \\
\text { (percent) }\end{array}$ & $\begin{array}{l}\text { Mean } \\
\text { annual } \\
\text { rainfall } \\
\text { (inches) }\end{array}$ & $\begin{array}{l}\text { Soil } \\
\text { type A } \\
\text { (percent) }\end{array}$ & $\begin{array}{c}\text { Soil } \\
\text { type B } \\
\text { (percent) }\end{array}$ \\
\hline 01476500 & $39^{\circ} 54^{\prime} 10^{\prime \prime}$ & $75^{\circ} 23^{\prime} 35^{\prime \prime}$ & 31.9 & 15.2 & 26.2 & 330 & 1.35 & 20 & 43.3 & -- & -- \\
\hline 01477000 & $39^{\circ} 52^{\prime} 03^{\prime \prime}$ & $75^{\circ} 52^{\prime} 43^{\prime \prime}$ & 61.1 & 20.5 & 23.1 & 320 & 1.30 & 20 & 43.4 & -- & -- \\
\hline 01478500 & $39^{\circ} 42^{\prime} 52^{\prime \prime}$ & $75^{\circ} 45^{\prime} 34^{\prime \prime}$ & 66.7 & 18.4 & 18.4 & 380 & .07 & 19 & 45.0 & -- & -- \\
\hline 01480000 & $39^{\circ} 45^{\prime} 52^{\prime \prime}$ & $75^{\circ} 38^{\prime} 08^{\prime \prime}$ & 47.0 & 18.2 & 16.6 & 340 & .82 & 18 & 46.0 & 0 & 7 \\
\hline 01481000 & $39^{\circ} 52^{\prime} 11^{\prime \prime}$ & $75^{\circ} 35^{\prime} 37^{\prime \prime}$ & 287 & 39.2 & 14.5 & 470 & 1.16 & 45 & 44.9 & -- & -- \\
\hline 01483200 & $39^{\circ} 21^{\prime} 58^{\prime \prime}$ & $75^{\circ} 40^{\prime} 10^{\prime \prime}$ & 3.85 & 2.4 & 15.8 & 64 & 1.90 & 43 & 44.5 & 8 & 43 \\
\hline 01483500 & $39^{\circ} 13^{\prime} 58^{\prime \prime}$ & $75^{\circ} 37^{\prime} 57^{\prime \prime}$ & 9.35 & 5.1 & 10.4 & 61 & .10 & 21 & 45.0 & 0 & 40 \\
\hline 01484000 & $38^{\circ} 58^{\prime} 33^{\prime \prime}$ & $75^{\circ} 34^{\prime} 03^{\prime \prime}$ & 13.6 & 6.1 & 6.3 & 57 & .65 & 35 & 47.0 & 7 & 43 \\
\hline 01484100 & $38^{\circ} 54^{\prime} 20^{\prime \prime}$ & $75^{\circ} 30^{\prime} 49^{\prime \prime}$ & 2.83 & 2.6 & 7.1 & 53 & .36 & 45 & 47,0 & 30 & 70 \\
\hline 01484500 & $38^{\circ} 38^{\prime} 19^{\prime \prime}$ & $75^{\circ} 20^{\prime} 31^{\prime \prime}$ & 5.24 & 4.5 & 4.9 & 46 & .04 & 51 & 47.0 & 27 & 69 \\
\hline 01485000 & $38^{\circ} 23^{\prime} 20^{\prime \prime}$ & $75^{\circ} 19^{\prime} 30^{\prime \prime}$ & 60.5 & 14.9 & 1.5 & 44 & 15.8 & 30 & 47.0 & 4 & 95 \\
\hline 01485500 & $38^{\circ} 13^{\prime} 44^{\prime \prime}$ & $75^{\circ} 28^{\prime} 19^{\prime \prime}$ & 44.9 & 13.1 & 3.6 & 46 & 6.20 & 85 & 47.0 & 8 & 84 \\
\hline 01486000 & $38^{\circ} 12^{\prime} 50^{\prime \prime}$ & $75^{\circ} 40^{\prime} 18^{\prime \prime}$ & 4.80 & 4.2 & 5.5 & 32 & .00 & 57 & 46.0 & 0 & 99.7 \\
\hline 01487000 & $38^{\circ} 43^{\prime} 42^{\prime \prime}$ & $75^{\circ} 33^{\prime} 44^{\prime \prime}$ & 75.4 & 14.3 & 3.2 & 50 & 1.70 & 40 & 45.5 & 18 & 48 \\
\hline 01488500 & $38^{\circ} 50^{\prime} 59^{\prime \prime}$ & $75^{\circ} 40^{\prime} 24^{\prime \prime}$ & 43.9 & 11.9 & 2.7 & 56 & .30 & 29 & 46.0 & 0 & 79 \\
\hline 01489000 & $38^{\circ} 42^{\prime} 44^{\prime \prime}$ & $75^{\circ} 47^{\prime} 34^{\prime \prime}$ & 7.10 & 5.5 & 7.6 & 46 & .47 & 33 & 45.0 & 0 & 50 \\
\hline 01490000 & $38^{\circ} 30^{\prime} 43^{\prime \prime}$ & $75^{\circ} 52^{\prime} 51^{\prime \prime}$ & 15.0 & 7.3 & 4.5 & 28 & .10 & 50 & 45.0 & 5 & 35 \\
\hline 01491000 & $38^{\circ} 59^{\prime} 50^{\prime \prime}$ & $75^{\circ} 47^{\prime} 09^{\prime \prime}$ & 113 & 19.0 & 3.0 & 60 & 1.91 & 35 & 45.0 & 5 & 76 \\
\hline 01493000 & $39^{\circ} 14^{\prime} 59^{\prime \prime}$ & $75^{\circ} 51^{\prime} 40^{\prime \prime}$ & 22.3 & 9.9 & 6.1 & 61 & 1.54 & 43 & 43.5 & 3 & 40 \\
\hline 01493500 & $39^{\circ} 16^{\prime} 48^{\prime \prime}$ & $76^{\circ} 00^{\prime} 54^{\prime \prime}$ & 12.7 & 6.1 & 9.1 & 60 & .20 & 8 & 43.0 & 0 & 7 \\
\hline 01495000 & $39^{\circ} 39^{\prime} 26^{\prime \prime}$ & $75^{\circ} 49^{\prime} 20^{\prime \prime}$ & 52.6 & 23.3 & 17.9 & 398 & .05 & 14 & 44.0 & -- & -- \\
\hline 01496000 & $39^{\circ} 37^{\prime} 38^{\prime \prime}$ & $75^{\circ} 56^{\prime} 40^{\prime \prime}$ & 24.3 & 14.0 & 24.0 & 380 & .09 & 22 & 43.5 & -- & -- \\
\hline 01496200 & $39^{\circ} 37^{\prime} 34^{\prime \prime}$ & $76^{\circ} 022^{\prime} 27^{\prime \prime}$ & 9.03 & 6.2 & 29.0 & 375 & .02 & 17 & 43.0 & -- & -- \\
\hline 01559700 & $39^{\circ} 58^{\prime} 40^{\prime \prime}$ & $78^{\circ} 37^{\prime} 08^{\prime \prime}$ & 5.30 & 3.9 & 147 & 1,680 & a 1.00 & 69 & 39.5 & -- & -. \\
\hline 01561000 & $39^{\circ} 57^{\prime} 20^{\prime \prime}$ & $78^{\circ} 15^{\prime} 15^{\prime \prime}$ & 36.8 & 11.0 & 26.2 & 1,550 & $\mathrm{a}_{1.00}$ & 70 & 39.2 & -- & -- \\
\hline 01577500 & $39^{\circ} 46^{\prime} 21^{\prime \prime}$ & $76^{\circ} 18^{\prime} 58^{\prime \prime}$ & 133 & 26.7 & 17.6 & 650 & $\mathrm{a}_{1.00}$ & 32 & 42.0 & -- & -- \\
\hline 01578500 & $39^{\circ} 41^{\prime} 24^{\prime \prime}$ & $76^{\circ} 07^{\prime} 43^{\prime \prime}$ & 193 & 36.0 & 8.8 & 497 & .00 & 32 & 42.0 & -. & -- \\
\hline 01580000 & $39^{\circ} 37^{\prime} 49^{\prime \prime}$ & $76^{\circ} 24^{\prime} 13^{\prime \prime}$ & 94.4 & 28.6 & 17.7 & 657 & .03 & 50 & 44.5 & -- & -- \\
\hline 01581500 & $39^{\circ} 32^{\prime} 30^{\prime \prime}$ & $76^{\circ} 19^{\prime} 50^{\prime \prime}$ & 8.52 & 5.9 & 38.2 & 390 & .12 & 22 & 43.0 & -- & -- \\
\hline 01581700 & $39^{\circ} 31^{\prime} 12^{\prime \prime}$ & $76^{\circ} 22^{\prime} 24^{\prime \prime}$ & 34.8 & 17.5 & 30.0 & 488 & .08 & 29 & 44.0 & -- & -- \\
\hline 01582000 & $39^{\circ} 36^{\prime} 16^{\prime \prime}$ & $76^{\circ} 37^{\prime} 16^{\prime \prime}$ & 52.9 & 15.6 & 33.8 & 658 & .06 & 27 & 45.0 & -- & -- \\
\hline 01583000 & $39^{\circ} 29^{\prime} 40^{\prime \prime}$ & $76^{\circ} 47^{\circ} 45^{\prime \prime}$ & 2.09 & 2.6 & 46.1 & 591 & .03 & 36 & 45.0 & -- & -- \\
\hline 01583500 & $39^{\circ} 30^{\prime} 38^{\prime \prime}$ & $76^{\circ} 40^{\prime} 37^{\prime \prime}$ & 59.8 & 17.1 & 24.5 & 544 & .06 & 44 & 45.0 & -- & -- \\
\hline 01584500 & $39^{\circ} 30^{\prime} 18^{\prime \prime}$ & $76^{\circ} 25^{\prime} 56^{\prime \prime}$ & 36.1 & 15.0 & 21.1 & 542 & .10 & 40 & 45.0 & -- & -- \\
\hline 01587000 & $39^{\circ} 21^{\prime} 56^{\prime \prime}$ & $76^{\circ} 53 \cdot 06^{\prime \prime}$ & 165 & 31.0 & 14.6 & 665 & .02 & 32 & 44.5 & -- & -- \\
\hline 01587500 & $39^{\circ} 21^{\prime} 05^{\prime \prime}$ & $76^{\circ} 54^{\prime} 50^{\prime \prime}$ & 64.4 & 16.4 & 26.2 & 642 & .00 & 22 & 43.0 & -- & -- \\
\hline 01588000 & $39^{\circ} 22^{\prime} 55^{\prime \prime}$ & $76^{\circ} 58^{\prime} 00^{\prime \prime}$ & 11.4 & 7.8 & 38.4 & 665 & .00 & 17 & 43.5 & -- & -- \\
\hline 01589200 & $39^{\circ} 26^{\prime} 16^{\prime \prime}$ & $76^{\circ} 46^{\prime} 57^{\prime \prime}$ & 4.90 & 4.1 & 38.6 & 648 & .14 & 14 & 44.5 & - & -- \\
\hline 01589440 & $39^{\circ} 23^{\prime} 30^{\prime \prime}$ & $76^{\circ} 39^{\prime} 42^{\prime \prime}$ & 25.2 & 9.7 & 31.7 & 491 & .14 & 44 & 44.5 & -- & -- \\
\hline 01590000 & $38^{\circ} 59^{\prime} 09^{\prime \prime}$ & $76^{\circ} 37^{\circ} 21$ " & 8.50 & 4.6 & 18.1 & 112 & 1.45 & 70 & 43.5 & 0 & 13 \\
\hline
\end{tabular}


Table 10. Basin characteristics at continuous-record streamflow-gaging stations in Maryland and Delaware--Continued

\begin{tabular}{|c|c|c|c|c|c|c|c|c|c|c|c|}
\hline $\begin{array}{l}\text { Station } \\
\text { no. }\end{array}$ & Latitude & Longitude & $\begin{array}{c}\text { Drainage } \\
\text { area } \\
\left(\mathbf{m i}^{2}\right)\end{array}$ & $\begin{array}{l}\text { Channel } \\
\text { length } \\
\text { (miles) }\end{array}$ & $\begin{array}{l}\text { Channel } \\
\text { slope } \\
\text { (ft/mi) }\end{array}$ & $\begin{array}{l}\text { Drainage } \\
\text { basin } \\
\text { elevation } \\
\text { (feet) }\end{array}$ & $\begin{array}{l}\text { Storage } \\
\text { (percent) }\end{array}$ & $\begin{array}{l}\text { Forest } \\
\text { cover } \\
\text { (percent) }\end{array}$ & $\begin{array}{l}\text { Mean } \\
\text { annual } \\
\text { rainfall } \\
\text { (inches) }\end{array}$ & \begin{tabular}{l}
\multicolumn{1}{c}{ Soil } \\
type A \\
(percent)
\end{tabular} & $\begin{array}{c}\text { Soil } \\
\text { type B } \\
\text { (percent) }\end{array}$ \\
\hline $01591000^{b}$ & $39^{\circ} 14^{\prime} 18^{\prime \prime}$ & $77^{\circ} 03^{\prime} 23^{\prime \prime}$ & 34.8 & 12.5 & 28.2 & 589 & 0.00 & 26 & 42.5 & - & -- \\
\hline 01591500 & $39^{\circ} 15^{\prime} 17^{\prime \prime}$ & $77^{\circ} 02^{\prime} 43^{\prime \prime}$ & 27.7 & 8.9 & 26.2 & 559 & .00 & 18 & 43.0 & -- & -- \\
\hline 01593500 & $39^{\circ} 10^{\prime} 04^{\prime \prime}$ & $76^{\circ} 51^{\prime} 07^{\prime \prime}$ & 38.0 & 16.1 & 22.1 & 409 & .06 & 33 & 43.0 & -- & -- \\
\hline 01594000 & $39^{\circ} 08^{\prime} 00^{\prime \prime \prime}$ & $76^{\circ} 48^{\prime} 58^{\prime \prime}$ & 98.4 & 24.4 & 9.8 & 439 & .06 & 22 & 43.0 & -- & -- \\
\hline 01594500 & $38^{\circ} 52^{\prime} 24^{\prime \prime}$ & $76^{\circ} 47^{\prime} 54^{\prime \prime}$ & 30.2 & 10.6 & 7.4 & 147 & .48 & 47 & 44.0 & 0 & 9 \\
\hline 01594600 & $38^{\circ} 38^{\prime} 27^{\prime \prime}$ & $76^{\circ} 38^{\prime} 07^{\prime \prime}$ & 3.85 & 2.8 & 22.8 & 106 & .00 & 46 & 44.0 & 8 & 14 \\
\hline 01594800 & $38^{\circ} 26^{\prime} 57^{\prime \prime}$ & $76^{\circ} 29^{\prime} 43^{\prime \prime}$ & 6.73 & 4.6 & 20.7 & 108 & .01 & 83 & 44.0 & 21 & 11 \\
\hline 01595300 & $39^{\circ} 22^{\prime} 00^{\prime \prime}$ & $79^{\circ} 10^{\prime} 45^{\prime \prime}$ & 47.3 & 16.8 & 70.6 & 2,670 & .00 & 75 & 41.0 & -- & - \\
\hline 01596500 & $39^{\circ} 34^{\prime} 05^{\prime \prime}$ & $79^{\circ} 06^{\prime} 10^{\prime \prime}$ & 49.1 & 19.1 & 65.1 & 2,510 & .62 & 81 & 44.0 & - & -- \\
\hline 01597000 & $39^{\circ} 30^{\prime} 00^{\prime \prime}$ & $7909 ’ 35^{\prime \prime}$ & 16.7 & 9.3 & 137 & 2,510 & .12 & 79 & 46.0 & - & -- \\
\hline 01599500 & $39^{\circ} 24^{\prime} 35^{\prime \prime}$ & $79^{\circ} 00^{\prime} 05^{\prime \prime}$ & 45.7 & 14.5 & 62.4 & 1,830 & .00 & 75 & 37.0 & - & -- \\
\hline 01601000 & $39^{\circ} 48^{\prime} 43^{\prime \prime}$ & $78^{\circ} 43^{\prime} 00^{\prime \prime}$ & 146 & 22.7 & 70.0 & 1,960 & ${ }^{\mathrm{a}} 1.00$ & 84 & 36.0 & - & -- \\
\hline 01603000 & $39^{\circ} 37^{\prime} 16^{\prime \prime}$ & $78^{\circ} 46^{\prime} 24^{\prime \prime}$ & 875 & 82.1 & 39.1 & 2,160 & .12 & 73 & 42.0 & -- & -- \\
\hline 01603500 & $39^{\circ} 47^{\prime} 23^{\prime \prime}$ & $78^{\circ} 38^{\prime} 48^{\prime \prime}$ & 30.2 & 12.3 & 54.6 & 1,570 & ${ }^{\mathrm{a}} 1.00$ & 59 & 35.5 & -- & -- \\
\hline 01606000 & 38 59'05” & 79 14'10" & 314 & 47.7 & 39.1 & 3,120 & .00 & 80 & 44.0 & -- & -- \\
\hline 01609000 & $39^{\circ} 33^{\prime} 12^{\prime \prime}$ & $78^{\circ} 33^{\prime} 19^{\prime \prime}$ & 148 & 40.3 & 13.5 & 1,310 & .05 & 79 & 36.0 & -- & -- \\
\hline 01609500 & $39^{\circ} 32^{\prime} 50^{\prime \prime}$ & $78^{\circ} 33^{\prime} 20^{\prime \prime}$ & 5.08 & 5.4 & 61.2 & 818 & .03 & 90 & 36.5 & -- & -- \\
\hline 01612500 & $39^{\circ} 42^{\prime} 45^{\prime \prime}$ & $78^{\circ} 13^{\prime} 55^{\prime \prime}$ & 16.9 & 5.8 & 93.6 & 851 & .24 & 89 & 37.5 & -- & -- \\
\hline 01613050 & $39^{\circ} 53^{\prime} 54^{\prime \prime}$ & $78^{\circ} 07^{\prime} 57^{\prime \prime}$ & 10.7 & 5.6 & 95.7 & 1,230 & .00 & 76 & 38.5 & -- & -- \\
\hline 01613500 & $39^{\circ} 43^{\prime} 20^{\prime \prime}$ & $78^{\circ} 03^{\prime} 52^{\prime \prime}$ & 158 & 45.7 & 11.3 & 1,020 & ${ }^{\mathrm{a}} 1.20$ & 56 & 40.0 & -- & -- \\
\hline 01613900 & $39^{\circ} 12^{\prime} 52^{\prime \prime}$ & $78^{\circ} 17^{\prime} 18^{\prime \prime}$ & 15.0 & 7.9 & 167 & 1,200 & 2.50 & 70 & 37.0 & -- & -- \\
\hline 01614090 & $39^{\circ} 55^{\prime} 48^{\prime \prime}$ & $77^{\circ} 26^{\prime} 23^{\prime \prime}$ & 5.05 & 4.1 & 102 & 1,530 & a 1.00 & 100 & 44.0 & -- & -- \\
\hline 01614500 & $39^{\circ} 42^{\prime} 57^{\prime \prime}$ & $77^{\circ} 49^{\prime} 28^{\prime \prime}$ & 494 & 61.1 & 11.2 & 1,050 & .05 & 37 & 39.5 & -- & -- \\
\hline 01617800 & $39^{\circ} 30^{\prime} 53^{\prime \prime}$ & $77^{\circ} 46^{\prime} 38^{\prime \prime}$ & 18.9 & 9.6 & 23.8 & 509 & .11 & 12 & 39.5 & -- & -- \\
\hline 01619000 & $39^{\circ} 42^{\prime} 59^{\prime \prime}$ & $77^{\circ} 36^{\prime} 28^{\prime \prime}$ & 93.5 & 16.3 & 59.2 & 1,010 & .18 & 46 & 40.0 & -- & -- \\
\hline 01637000 & $39^{\circ} 28^{\prime} 54^{\prime \prime}$ & $77^{\circ} 32^{\prime} 17^{\prime \prime}$ & 8.83 & 5.1 & 210 & 1,010 & .01 & 48 & 42.0 & -- & -- \\
\hline 01637500 & $39^{\circ} 25^{\prime} 35^{\prime \prime}$ & $77^{\circ} 33^{\prime} 25^{\prime \prime}$ & 66.9 & 23.9 & 47.5 & 1,110 & .02 & 37 & 42.5 & -- & -- \\
\hline 01638480 & $39^{\circ} 15^{\prime} 18^{\prime \prime}$ & $77^{\circ} 34^{\prime} 36^{\prime \prime}$ & 89.6 & 27.5 & 14.1 & 600 & ${ }^{\mathrm{a}} 1.00$ & 30 & 41.3 & - & -- \\
\hline 01639000 & $39^{\circ} 40^{\prime} 43^{\prime \prime}$ & $77^{\circ} 14^{\prime} 06^{\prime \prime}$ & 173 & 31.5 & 18.9 & 597 & .00 & 24 & 43.5 & -- & -- \\
\hline 01640500 & $39^{\circ} 40^{\prime} 36^{\prime \prime}$ & $77^{\circ} 27^{\prime} 50^{\prime \prime}$ & 5.93 & 4.1 & 202 & 1,460 & .00 & 71 & 47.5 & -- & -- \\
\hline 01641000 & $39^{\circ} 35^{\prime} 40^{\prime \prime}$ & $77^{\circ} 23^{\prime} 50^{\prime \prime}$ & 18.4 & 8.8 & 135 & 1,100 & .34 & 77 & 46.0 & -- & - \\
\hline 01641500 & $39^{\circ} 31^{\prime} 35^{\prime \prime}$ & $77^{\circ} 28^{\prime} 00^{\prime \prime}$ & 7.29 & 4.2 & 263 & 1,450 & .00 & 100 & 46.5 & -- & -- \\
\hline 01642500 & $39^{\circ} 24^{\prime} 55^{\prime \prime}$ & $77^{\circ} 20^{\prime} 00^{\prime \prime}$ & 82.3 & 20.1 & 19.2 & 576 & .01 & 20 & 42.5 & -- & - \\
\hline 01643500 & $39^{\circ} 17^{\prime} 40^{\prime \prime}$ & $77^{\circ} 24^{\prime} 30^{\prime \prime}$ & 62.8 & 15.6 & 23.8 & 521 & .01 & 26 & 42.0 & -- & -- \\
\hline 01645000 & $39^{\circ} 07^{\prime} 41^{\prime \prime}$ & $77^{\circ} 20^{\prime} 13^{\prime \prime}$ & 101 & 20.9 & 15.1 & 468 & .01 & 20 & 42.0 & -- & -- \\
\hline 01650500 & $39^{\circ} 03^{\prime} 55^{\prime \prime}$ & $77^{\circ} 01^{\prime} 48^{\prime \prime}$ & 21.1 & 8.1 & 19.3 & 415 & .04 & 31 & 43.5 & -- & -- \\
\hline 01653600 & $38^{\circ} 42^{\prime} 20^{\prime \prime}$ & $76^{\circ} 58^{\prime} 00^{\prime \prime}$ & 39.5 & 14.7 & 16.1 & 197 & 2.46 & 42 & 44.0 & 5 & 10 \\
\hline 01658000 & $38^{\circ} 35^{\prime} 45^{\prime \prime}$ & $77^{\circ} 03^{\prime} 25^{\prime \prime}$ & 54.8 & 17.6 & 10.5 & 183 & 3.21 & 69 & 45.5 & 9 & 32 \\
\hline 01661000 & $38^{\circ} 22^{\prime} 45^{\prime \prime}$ & $76^{\circ} 46^{\prime} 56^{\prime \prime}$ & 10.4 & 6.7 & 21.2 & 133 & .00 & 66 & 42.5 & 17 & 7 \\
\hline 01661050 & $38^{\circ} 20^{\prime} 00^{\prime \prime}$ & $76^{\circ} 43^{\prime} 31^{\prime \prime}$ & 18.5 & 7.3 & 12.4 & 112 & .00 & 60 & 44.5 & 24 & 10 \\
\hline
\end{tabular}


Table 10. Basin characteristics at continuous-record streamflow-gaging stations in Maryland and Delaware--Continued

\begin{tabular}{|c|c|c|c|c|c|c|c|c|c|c|c|}
\hline $\begin{array}{l}\text { Station } \\
\text { no. }\end{array}$ & Latitude & Longitude & $\begin{array}{c}\text { Drainage } \\
\text { area } \\
\left(\mathbf{m i}^{2}\right)\end{array}$ & $\begin{array}{l}\text { Channel } \\
\text { length } \\
\text { (miles) }\end{array}$ & $\begin{array}{l}\text { Channel } \\
\text { slope } \\
\text { (ft/mi) }\end{array}$ & $\begin{array}{l}\text { Drainage } \\
\text { basin } \\
\text { elevation } \\
\text { (feet) }\end{array}$ & $\begin{array}{l}\text { Storage } \\
\text { (percent) }\end{array}$ & $\begin{array}{l}\text { Forest } \\
\text { cover } \\
\text { (percent) }\end{array}$ & $\begin{array}{l}\text { Mean } \\
\text { annual } \\
\text { rainfall } \\
\text { (inches) }\end{array}$ & $\begin{array}{c}\text { Soil } \\
\text { type A } \\
\text { (percent) }\end{array}$ & $\begin{array}{c}\text { Soil } \\
\text { type B } \\
\text { (percent) }\end{array}$ \\
\hline 01661500 & $38^{\circ} 14^{\prime} 36^{\prime \prime}$ & $76^{\circ} 30^{\prime} 13^{\prime \prime}$ & 24.0 & 8.1 & 12.9 & 101 & 0.31 & 82 & 41.0 & 8 & 12 \\
\hline 01661800 & $37^{\circ} 52^{\prime} 36^{\prime \prime}$ & $76^{\circ} 29^{\prime} 42^{\prime \prime}$ & 6.82 & 4.2 & 20.3 & 80 & ${ }^{\mathrm{a}} 1.00$ & 85 & 41.7 & -- & - \\
\hline 01668500 & $38^{\circ} 02^{\prime} 23^{\prime \prime}$ & $76^{\circ} 49^{\prime} 38^{\prime \prime}$ & 45.6 & 10.4 & 13.5 & 110 & ${ }^{\mathrm{a}} 1.01$ & 82 & 41.2 & -- & $\ldots$ \\
\hline 03039200 & $40^{\circ} 02^{\prime} 49^{\prime \prime}$ & $78^{\circ} 50^{\prime} 00^{\prime \prime}$ & 3.68 & 3.3 & 184 & 2,690 & $\mathrm{a}_{1.00}$ & 97 & 46.5 & .. & -- \\
\hline 03062400 & $39^{\circ} 36^{\prime} 30^{\prime \prime}$ & $79^{\circ} 57^{\prime} 20^{\prime \prime}$ & 10.9 & 8.4 & 132 & 1,420 & ${ }^{\mathrm{a}} 1.00$ & 75 & 44.0 & - & -- \\
\hline 03062500 & $39^{\circ} 37^{\prime} 45^{\prime \prime}$ & $79^{\circ} 57^{\prime} 10^{\prime \prime}$ & 63.2 & 23.4 & 46.0 & 1,770 & .00 & 65 & 44.0 & -- & -- \\
\hline 03065000 & $39^{\circ} 04^{\prime} 20^{\prime \prime}$ & $79^{\circ} 37^{\prime} 20^{\prime \prime}$ & 345 & 37.6 & 41.8 & 3,310 & .00 & 80 & 48.0 & -- & -- \\
\hline 03066000 & $39^{\circ} 07^{\prime} 35^{\prime \prime}$ & $79^{\circ} 28^{\prime} 10^{\prime \prime}$ & 86.2 & 21.4 & 8.1 & 3,250 & .00 & 50 & 52.0 & -- & -- \\
\hline 03075500 & $39^{\circ} 25^{\prime} 19^{\prime \prime}$ & $79^{\circ} 25^{\prime} 32^{\prime \prime}$ & 134 & 20.0 & 6.1 & 2,610 & .25 & 64 & 50.0 & -- & -. \\
\hline 03076600 & $39^{\circ} 39^{\prime} 22^{\prime \prime}$ & $79^{\circ} 23^{\circ} 41^{\prime \prime}$ & 48.9 & 15.9 & 65.6 & 2,460 & .12 & 44 & 48.0 & -- & -- \\
\hline 03078000 & $39^{\circ} 42^{\prime} 08^{\prime \prime}$ & $79^{\circ} 08^{\prime} 12^{\prime \prime}$ & 62.5 & 17.3 & 32.4 & 2,610 & .00 & 80 & 45.5 & -- & -. \\
\hline 03079000 & $39^{\circ} 51^{\prime} 35^{\prime \prime}$ & $79^{\circ} 13^{\prime} 40^{\prime \prime}$ & 382 & 52.2 & 14.7 & 2.420 & ${ }^{\mathrm{a}} 1.24$ & 64 & 46.0 & -- & -. \\
\hline 03080000 & $39^{\circ} 49^{\prime} 22^{\prime \prime}$ & $79^{\circ} 19^{\prime} 14^{\prime \prime}$ & 121 & 32.6 & 24.8 & 2,270 & a 1.40 & 86 & 47.2 & -- & $\ldots$ \\
\hline 03082200 & $40^{\circ} 00^{\prime} 59^{\prime \prime}$ & $79^{\circ} 25^{\prime} 33^{\prime \prime}$ & 9.30 & 5.6 & 132 & 1,930 & ${ }^{\mathrm{a}} 1.00$ & 60 & 47.4 & -- & -- \\
\hline
\end{tabular}

a Likely to be an estimated, rather than measured value.

b Station not used in developing regional estimation equations. 
Table 11. Low-flow characteristics at continuous-record streamflow-gaging stations in Maryland and Delaware

[Years given are climatic years, the 12-month period from April 1 through March 31. Footnotes found at end of table]

\begin{tabular}{|c|c|c|c|c|c|c|c|c|c|c|c|}
\hline \multirow{3}{*}{$\begin{array}{l}\text { Station } \\
\text { no. }\end{array}$} & \multirow{3}{*}{$\begin{array}{l}\text { Years of } \\
\text { record } \\
\text { used }\end{array}$} & \multirow{3}{*}{$\begin{array}{l}\text { First } \\
\text { year } \\
\text { used }\end{array}$} & \multicolumn{9}{|c|}{ Low-flow discharge, in cubic feet per second } \\
\hline & & & \multicolumn{3}{|c|}{ 7-day } & \multicolumn{3}{|c|}{ 14-day } & \multicolumn{3}{|c|}{ 30-day } \\
\hline & & & 2-year & 10-year & 20-year & 2-year & 10-year & 20-year & 2-year & 10-year & 20-year \\
\hline 01476500 & 22 & 1932 & 11.3 & 4.9 & 3.7 & 12.4 & 5.4 & 4.1 & 14.4 & 6.4 & 4.9 \\
\hline 01477000 & 55 & 1932 & 23.5 & 12.5 & 10.3 & 26.0 & 13.8 & 11.3 & 29.8 & 15.8 & 12.8 \\
\hline 01478500 & 23 & 1952 & 24.2 & 10.7 & 8.2 & 26.0 & 11.9 & 9.1 & 29.0 & 13.4 & 10.4 \\
\hline 01480000 & 44 & 1943 & 17.7 & 9.7 & 8.1 & 19.0 & 10.5 & 8.7 & 21.1 & 12.1 & 10.2 \\
\hline 01481000 & 42 & 1912 & 118 & 70.6 & 60.1 & 124 & 73.2 & 62.0 & 138 & 79.6 & 67.0 \\
\hline 01483200 & 30 & 1957 & .3 & .06 & .00 & .4 & .07 & .03 & .6 & .1 & .06 \\
\hline 01483500 & 15 & 1932 & 2.9 & 1.9 & 1.7 & 3.1 & 2.2 & 2.0 & 3.6 & 2.5 & 2.2 \\
\hline 01484000 & 24 & 1961 & 2.9 & 1.8 & 1.6 & 3.1 & 2.0 & 1.8 & 3.5 & 2.2 & 1.9 \\
\hline 01484100 & 28 & 1959 & .9 & .3 & .2 & .9 & .3 & .2 & .9 & .4 & .3 \\
\hline 01484500 & 44 & 1943 & 1.6 & .6 & .4 & 1.7 & .7 & .5 & 1.8 & .8 & .6 \\
\hline 01485000 & 37 & 1950 & 6.5 & 3.4 & 2.9 & 7.2 & 3.8 & 3.3 & 8.4 & 4.3 & 3.7 \\
\hline 01485500 & 37 & 1950 & 2.4 & 1.5 & 1.4 & 2.8 & 1.6 & 1.4 & 3.7 & 1.7 & 1.5 \\
\hline 01486000 & ${ }^{a} 16$ & 1952 & .1 & .00 & .00 & .2 & .04 & .00 & .2 & .05 & .00 \\
\hline 01487000 & 44 & 1943 & 24.6 & 14.8 & 12.7 & 25.7 & 15.5 & 13.4 & 27.4 & 16.8 & 14.7 \\
\hline 01488500 & ${ }^{a} 25$ & 1943 & 4.5 & 2.1 & 1.7 & 5.0 & 2.4 & 1.9 & 5.6 & 2.8 & 2.4 \\
\hline 01489000 & 36 & 1951 & 1.1 & .3 & .2 & 1.2 & .5 & .4 & 1.4 & .7 & .6 \\
\hline 01490000 & 28 & 1952 & 4.1 & 1.2 & .7 & 4.4 & 2.1 & 1.6 & 4.8 & 2.9 & 2.5 \\
\hline 01491000 & 38 & 1948 & 12.7 & 5.5 & 4.2 & 14.2 & 6.4 & 5.0 & 16.0 & 7.6 & 6.2 \\
\hline 01493000 & 38 & 1948 & 7.2 & 4.2 & 3.6 & 7.9 & 4.7 & 3.9 & 8.6 & 5.1 & 4.2 \\
\hline 01493500 & 35 & 1952 & 3.2 & 1.6 & 1.3 & 3.4 & 1.7 & 1.4 & 3.9 & 1.9 & 1.6 \\
\hline 01495000 & 55 & 1932 & 19.1 & 10.0 & 8.1 & 21.0 & 10.8 & 8.7 & 23.4 & 12.4 & 10.1 \\
\hline 01496000 & 35 & 1949 & 5.5 & 2.7 & 2.1 & 6.0 & 3.0 & 2.4 & 6.8 & 3.4 & 2.7 \\
\hline 01496200 & 19 & 1968 & 2.6 & 1.2 & .9 & 2.7 & 1.2 & 1.0 & 3.0 & 1.5 & 1.2 \\
\hline 01559700 & 16 & 1962 & .2 & .08 & .00 & .2 & .08 & .06 & .3 & .1 & .1 \\
\hline 01561000 & 27 & 1930 & 1.6 & .5 & .4 & 1.9 & 6 & .4 & 2.5 & .8 & .6 \\
\hline 01577500 & 12 & 1929 & 48.2 & 29.6 & 25.7 & 52.2 & 30.9 & 26.2 & 58.1 & 33.0 & 27.9 \\
\hline 01578500 & 17 & 1933 & 93.3 & 48.0 & 37.3 & 100 & 50.0 & 40.0 & 109 & 56.5 & 44.4 \\
\hline 01580000 & 60 & 1927 & 46.3 & 25.4 & 20.5 & 48.3 & 26.7 & 21.8 & 51.6 & 29.6 & 24.8 \\
\hline 01581500 & 19 & 1945 & 1.3 & .3 & .1 & 1.4 & .4 & .2 & 1.8 & .8 & .6 \\
\hline 01581700 & 19 & 1968 & 15.5 & 8.9 & 7.7 & 16.1 & 9.6 & 8.4 & 18.1 & 10.9 & 9.6 \\
\hline 01582000 & 42 & 1945 & 25.2 & 13.1 & 10.4 & 26.6 & 14.0 & 11.2 & 28.4 & 15.9 & 13.1 \\
\hline 01583000 & 33 & 1948 & .7 & .3 & .2 & .8 & .3 & .2 & .9 & .4 & .2 \\
\hline 01583500 & 42 & 1945 & 23.7 & 11.0 & 8.4 & 24.9 & 11.7 & 9.1 & 26.5 & 13.4 & 10.8 \\
\hline 01584500 & 43 & 1927 & 15.2 & 7.6 & 6.0 & 16.2 & 8.1 & 6.4 & 17.8 & 9.2 & 7.4 \\
\hline 01587000 & 22 & 1930 & 50.3 & 27.4 & 22.5 & 54.6 & 29.6 & 24.2 & 62.6 & 34.3 & 28.0 \\
\hline 01587500 & 31 & 1949 & 19.8 & 5.3 & 3.0 & 20.1 & 6.6 & 4.4 & 20.9 & 8.9 & 6.8 \\
\hline 01588000 & 26 & 1932 & 3.7 & 1.6 & 1.3 & 4.0 & 1.8 & 1.3 & 4.5 & 2.0 & 1.6 \\
\hline 01589200 & 16 & 1959 & 1.7 & .9 & .7 & 1.8 & 1.0 & .8 & 2.0 & 1.2 & 1.1 \\
\hline 01589440 & 21 & 1966 & 9.1 & 4.2 & 3.3 & 9.6 & 4.4 & 3.5 & 10.9 & 5.2 & 4.2 \\
\hline 01590000 & 42 & 1932 & 3.7 & 2.0 & 1.7 & 4.0 & 2.2 & 1.8 & 4.5 & 2.6 & 2.2 \\
\hline
\end{tabular}


Table 11. Low-flow characteristics at continuous-record streamflow-gaging stations in Maryland and Delaware--Continued

\begin{tabular}{|c|c|c|c|c|c|c|c|c|c|c|c|}
\hline \multirow{3}{*}{$\begin{array}{l}\text { Station } \\
\text { no. }\end{array}$} & \multirow{3}{*}{$\begin{array}{l}\text { Years of } \\
\text { record } \\
\text { used }\end{array}$} & \multirow{3}{*}{$\begin{array}{l}\text { First } \\
\text { year } \\
\text { used }\end{array}$} & \multicolumn{9}{|c|}{ Low-flow discharge, in cubic feet per second } \\
\hline & & & \multicolumn{3}{|c|}{ 7-day } & \multicolumn{3}{|c|}{ 14-day } & \multicolumn{3}{|c|}{ 30-day } \\
\hline & & & 2-year & 10-year & 20-year & 2-year & 10-year & 20-year & 2-year & 10-year & 20-year \\
\hline $01591000^{b}$ & 42 & 1945 & 8.4 & 2.7 & 1.8 & 8.7 & 3.3 & 2.4 & 9.4 & 4.4 & 3.5 \\
\hline 01591500 & 11 & 1945 & 9.3 & 3.8 & 2.6 & 10.0 & 4.1 & 2.8 & 11.7 & 4.5 & 3.2 \\
\hline 01593500 & 30 & 1932 & 9.2 & 4.2 & 3.3 & 10.2 & 4.7 & 3.6 & 11.7 & 5.2 & 4.0 \\
\hline 01594000 & 18 & 1940 & 21.9 & 11.7 & 9.8 & 23.8 & 13.0 & 11.0 & 27.6 & 14.5 & 12.0 \\
\hline 01594500 & 25 & 1950 & 2.7 & .4 & .1 & 2.9 & .6 & .3 & 3.4 & 1.0 & .7 \\
\hline 01594600 & 19 & 1957 & .3 & .00 & .00 & .4 & .00 & .00 & .5 & .1 & .06 \\
\hline 01594800 & 11 & 1957 & 1.1 & .2 & .00 & 1.4 & .4 & .00 & 1.9 & .4 & .2 \\
\hline 01595300 & 25 & 1957 & 2.5 & .5 & .3 & 3.0 & .6 & .3 & 4.2 & 1.0 & .7 \\
\hline 01596500 & 38 & 1949 & 2.3 & 1.0 & .7 & 2.8 & 1.1 & .9 & 3.8 & 1.8 & 1.4 \\
\hline 01597000 & 32 & 1949 & 1.7 & 1.0 & .9 & 1.8 & 1.1 & 1.0 & 2.0 & 1.3 & 1.2 \\
\hline 01599500 & 15 & 1948 & 2.2 & 1.0 & .8 & 2.4 & 1.1 & .9 & 2.9 & 1.4 & 1.1 \\
\hline 01601000 & 15 & 1952 & 2.3 & .8 & .7 & 2.9 & 1.0 & .8 & 5.3 & 2.0 & 1.6 \\
\hline 01603000 & 20 & 1930 & 104 & 40.5 & 27.6 & 112 & 46.8 & 33.1 & 129 & 54.7 & 39.5 \\
\hline 01603500 & 49 & 1933 & 3.0 & 1.8 & 1.6 & 3.3 & 2.0 & 1.7 & 3.7 & 2.2 & 1.9 \\
\hline 01606000 & 22 & 1940 & 17.9 & 7.3 & 5.7 & 20.8 & 7.8 & 5.9 & 25.6 & 9.4 & 7.1 \\
\hline 01609000 & 19 & 1929 & 7.0 & 2.0 & 1.4 & 8.2 & 2.3 & 1.5 & 10.1 & 3.0 & 2.0 \\
\hline 01609500 & 10 & 1948 & .00 & .00 & .00 & .00 & .00 & .00 & .00 & .00 & .00 \\
\hline 01612500 & 15 & 1948 & .08 & .00 & .00 & .09 & .00 & .00 & .2 & .00 & .00 \\
\hline 01613050 & 20 & 1966 & .06 & .00 & .00 & .1 & .00 & .00 & .3 & .02 & .00 \\
\hline 01613500 & 10 & 1931 & 11.1 & 6.3 & 5.4 & 12.7 & 6.8 & 5.5 & 15.8 & 8.0 & 6.3 \\
\hline 01613900 & 25 & 1961 & .8 & .4 & .3 & .9 & .5 & .4 & 1.0 & .6 & .5 \\
\hline 01614090 & 19 & 1961 & .8 & .2 & .2 & .8 & .3 & .2 & 1.0 & .4 & .2 \\
\hline 01614500 & 58 & 1929 & 89.2 & 53.4 & 45.5 & 93.6 & 56.2 & 48.2 & 104 & 63.9 & 55.9 \\
\hline 01617800 & 23 & 1964 & 3.4 & 1.4 & 1.0 & 3.8 & 1.6 & 1.2 & 4.1 & 1.8 & 1.4 \\
\hline 01619000 & 17 & 1949 & 38.6 & 23.7 & 19.9 & 40.3 & 24.1 & 20.1 & 42.6 & 26.0 & 22.0 \\
\hline 01637000 & 10 & 1948 & 1.1 & .6 & .4 & 1.2 & .6 & .5 & 1.4 & .8 & .6 \\
\hline 01637500 & 39 & 1948 & 3.9 & 1.0 & .6 & 4.6 & 1.3 & .7 & 6.2 & 1.9 & 1.3 \\
\hline 01638480 & 15 & 1972 & 7.0 & 1.3 & .7 & 7.9 & 1.5 & .8 & 10.1 & 2.2 & 1.2 \\
\hline 01639000 & 44 & 1943 & 4.7 & .8 & .4 & 5.9 & 1.3 & .7 & 8.1 & 2.8 & 2.0 \\
\hline 01640500 & 24 & 1960 & .5 & .2 & .1 & .6 & .2 & .09 & .7 & .3 & .2 \\
\hline 01641000 & 19 & 1950 & 1.9 & 1.1 & 1.0 & 2.1 & 1.2 & 1.0 & 2.5 & 1.5 & 1.3 \\
\hline 01641500 & 36 & 1948 & 1.5 & .9 & .8 & 1.6 & 1.0 & .8 & 1.8 & 1.1 & 1.0 \\
\hline 01642500 & 36 & 1935 & 15.2 & 6.8 & 5.2 & 16.5 & 7.5 & 5.6 & 18.3 & 9.0 & 7.1 \\
\hline 01643500 & 29 & 1949 & 11.3 & 6.3 & 5.3 & 12.1 & 6.8 & 5.8 & 14.1 & 7.9 & 6.8 \\
\hline 01645000 & 56 & 1931 & 23.6 & 7.5 & 4.6 & 25.6 & 8.0 & 5.0 & 29.4 & 10.8 & 7.8 \\
\hline 01650500 & 15 & 1924 & 3.6 & 1.0 & .6 & 4.2 & 1.1 & .7 & 5.1 & 1.5 & 1.0 \\
\hline 01653600 & 21 & 1966 & .1 & .00 & .00 & .6 & .00 & .00 & 1.4 & .00 & .00 \\
\hline 01658000 & 22 & 1950 & .00 & .00 & .00 & .00 & .00 & .00 & .1 & .00 & .00 \\
\hline 01661000 & 24 & 1948 & .4 & .00 & .00 & .7 & .00 & .00 & 1.1 & .1 & .02 \\
\hline 01661050 & 18 & 1969 & .6 & .00 & .00 & .9 & .00 & .00 & 1.5 & .1 & .05 \\
\hline
\end{tabular}


Table 11. Low-flow characteristics at continuous-record streamflow-gaging stations in Maryland and Delaware--Continued

\begin{tabular}{|c|c|c|c|c|c|c|c|c|c|c|c|}
\hline \multirow{3}{*}{$\begin{array}{l}\text { Station } \\
\text { no. }\end{array}$} & \multirow{3}{*}{$\begin{array}{l}\text { Years of } \\
\text { record } \\
\text { used }\end{array}$} & \multirow{3}{*}{$\begin{array}{c}\text { First } \\
\text { year } \\
\text { used }\end{array}$} & \multicolumn{9}{|c|}{ Low-flow discharge, in cubic feet per second } \\
\hline & & & \multicolumn{3}{|c|}{ 7-day } & \multicolumn{3}{|c|}{ 14-day } & \multicolumn{3}{|c|}{ 30-day } \\
\hline & & & 2-year & 10-year & 20-year & 2-year & 10-year & 20-year & 2-year & 10-year & 20-year \\
\hline 01661500 & 28 & 1947 & 2.7 & 1.1 & 0.8 & 3.2 & 1.3 & 1.0 & 3.8 & 1.7 & 1.3 \\
\hline 01661800 & 21 & 1964 & .7 & .07 & .00 & .8 & .1 & .01 & 1.2 & .2 & .1 \\
\hline 01668500 & 43 & 1944 & 1.8 & .09 & .00 & 2.4 & .3 & .1 & 4.2 & .7 & .4 \\
\hline 03039200 & 13 & 1965 & .2 & .07 & .05 & .3 & .1 & .08 & .4 & .2 & .1 \\
\hline 03062400 & 22 & 1965 & .06 & .00 & .00 & .2 & .00 & .00 & .4 & .02 & .00 \\
\hline 03062500 & 23 & 1946 & 2.6 & 1.0 & .8 & 3.2 & 1.2 & 1.0 & 4.3 & 1.7 & 1.4 \\
\hline 03065000 & 46 & 1941 & 33.3 & 11.8 & 8.6 & 41.5 & 14.3 & 10.3 & 62.9 & 19.7 & 13.6 \\
\hline 03066000 & 65 & 1922 & 11.7 & 5.1 & 3.9 & 14.1 & 5.8 & 4.4 & 19.8 & 7.5 & 5.5 \\
\hline 03075500 & 45 & 1942 & 17.9 & 5.6 & 3.8 & 20.0 & 6.2 & 4.3 & 26.3 & 8.9 & 6.3 \\
\hline 03076600 & 22 & 1965 & 7.0 & 3.3 & 2.6 & 7.7 & 3.7 & 3.0 & 9.1 & 4.5 & 3.8 \\
\hline 03078000 & 39 & 1948 & 4.8 & 1.5 & 1.0 & 5.9 & 1.8 & 1.3 & 8.3 & 2.7 & 1.9 \\
\hline 03079000 & 65 & 1921 & 34.6 & 17.2 & 14.1 & 41.1 & 19.1 & 15.2 & 53.9 & 23.4 & 18.3 \\
\hline 03080000 & 67 & 1919 & 12.4 & 5.5 & 4.3 & 15.3 & 6.4 & 4.9 & 21.0 & 8.5 & 6.4 \\
\hline 03082200 & 16 & 1962 & .4 & .05 & .02 & .5 & .1 & .06 & .7 & .2 & .1 \\
\hline
\end{tabular}

a Annual low-flow records used only through March 1968, after which extensive ditching of upstream channels began.

b Station not used in developing regional estimation equations. 
Table 12.--Basin characteristics and low-flow characteristics at partial-record

streamflow-gaging stations in Maryland and Delaware

[Latitude and longitude are reported in degrees, minutes, and seconds; $\mathrm{mi}^{2}$, square miles; mi, mile; $\mathrm{ft} / \mathrm{mi}$, foot per mile; ft, foot; in., inch; $\mathrm{ft}^{3} / \mathrm{s}$, cubic foot per second; ND, no data]

01477400 South Branch Naaman Creek near Claymont, Del.

Location: Lat $39^{\circ} 49^{\prime} 00^{\prime \prime}$, long $75^{\circ} 29^{\prime} 40^{\prime \prime}$, New Castle County, at dam 800 ft above bridge on Marsh Road, $2.2 \mathrm{mi}$ west' of Claymont.

Basin characteristics:

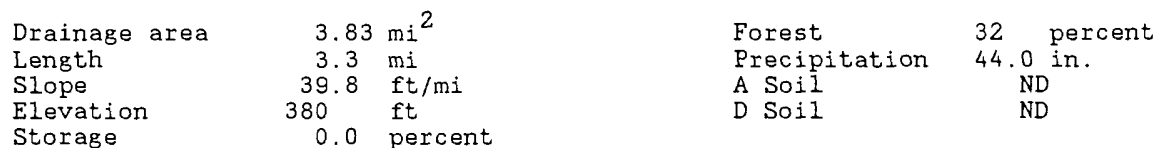

Low-flow characteristics:

$$
\frac{\begin{array}{c}
\text { Discharge } \\
\left(\mathrm{ft}^{3} / \mathrm{s}\right)
\end{array}}{\begin{array}{c}
7-\text { day } \\
14-\text { day } \\
30-\text { day }
\end{array}}
$$

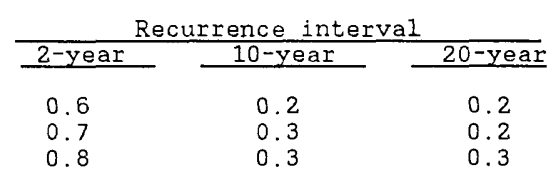

Basis of low-flow estimates:

Correlated with 01480000 , Red Clay Creek at Wooddale, Del.

Number of base-flow observations used -- 16

Base-flow observations used, made in 1955-59, 1961, 1962, 1965, 1968, 1969, 1971

Equivalent years of record -- 13

Coefficient of determination $\left(R^{2}\right)--0.87$

Standard error of estimate (SE) - 31 percent

Minimum observed discharge used in correlation -- $0.29 \mathrm{ft}^{3} / \mathrm{s}$

01479500 Mill Creek at Stanton, Del.

Location: Lat $39^{\circ} 42^{\prime} 50^{\prime \prime}$, long $75^{\circ} 40^{\prime} 00^{\prime \prime}$, New Castle County, at highway bridge, 1.2 mi west of Stanton.

Basin characteristics:

$\begin{array}{lrlll}\text { Drainage area } & 12.4 \mathrm{mi}^{2} & \text { Forest } & 21 \mathrm{percent} \\ \text { Length } & 16.4 \mathrm{mi} & \text { Precipitation } & 44.0 \mathrm{in} \\ \text { Slope } & 16.9 \mathrm{ft} / \mathrm{mi} & \text { A Soil } & \mathrm{ND} \\ \text { Elevation } & 257 & \mathrm{ft} & \text { D Soil } & \text { ND } \\ \text { Storage } & 0.18 \text { percent } & & \end{array}$

Low-flow characteristics:

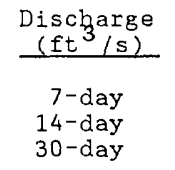

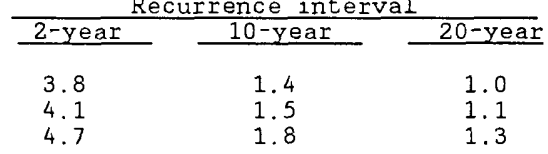

Basis of low-flow estimates:

Correlated with 01478500, White Clay Creek above Newark, Del.

Number of base-flow observations used - 18

Base-flow observations used, made in 1955-65, 1969

Equivalent years of record -- 12

Coefficient of determination $\left(\mathrm{R}^{2}\right)-0.97$

Standard error of estimate (SE) -- 13 percent

Minimum observed discharge used in correlation -- $1.97 \mathrm{ft}^{3} / \mathrm{s}$ 
Table 12.--Basin characteristics and low-flow characteristics at partial-record streamflow-gaging stations in Maryland and Delaware--Continued

01481440 Wilson Run at Rockland, Del.

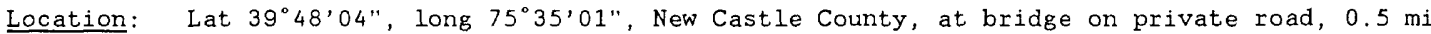
northwest of Rockland.

Basin characteristics:

$\begin{array}{lclc}\text { Drainage area } & 3.05 \mathrm{mi}^{2} & \text { Forest } & 17 \text { percent } \\ \text { Length } & 2.5 \mathrm{mi} & \text { Precipitation } & 44.0 \text { in. } \\ \text { Slope } & 81.3 \mathrm{ft} / \mathrm{mi} & \text { A Soil } & \text { ND } \\ \text { Elevation } & 355 & \text { D Soil } & \text { ND } \\ \text { Storage } & 0.0 \text { percent } & & \end{array}$

Low-flow characteristics:

Discharge
$(\mathrm{ft} / \mathrm{s})$
$\begin{gathered}7 \text {-day } \\ 14-\text { day } \\ 30-\text { day }\end{gathered}$

\begin{tabular}{ccc}
\multicolumn{3}{c}{ Recurrence interval } \\
\cline { 1 - 1 } 2 -year & $\frac{10 \text {-year }}{3.7}$ & 20-year \\
0.9 & 0.3 & 0.2 \\
1.6 & 0.3 & 0.2 \\
& 0.5 & 0.4
\end{tabular}

Basis of low-flow estimates:

Correlated with 01477800 , Shellpot Creek at Wilmington, Del.

Number of base-flow observations used -- 10

Base-flow observations used, made in 1957-63

Equivalent years of record -- 18

Coefficient of determination $\left(R^{2}\right)-0.96$

Standard error of estimate (SE) - 19 percent

Minimum observed discharge used in correlation -- $0.40 \mathrm{ft}^{3} / \mathrm{s}$

01482298 Red Lion Creek near Red Lion, Del.

Location: Lat $39^{\circ} 36^{\prime} 16^{\prime \prime}$, long $75^{\circ} 40^{\prime} 06^{\prime \prime}$, New Castle County, at culvert on U.S. Highway 301S, $0.2 \mathrm{mi}$ southwest of Red Lion.

Basin characteristics:

Drainage area
Length
Slope
Elevation
Storage

$3.08 \mathrm{mi}^{2}$
$2.1 \mathrm{mi}$
$33.6 \mathrm{ft} / \mathrm{mi}$
68 ft
0.13 percent

$\begin{array}{lcl}\text { Forest } & 26 & \text { percent } \\ \text { Precipitation } & 46.0 & \text { in. } \\ \text { A Soil } & 0 & \text { percent } \\ \text { D Soil } & 8 & \text { percent }\end{array}$

Low-flow characteristics:

\begin{tabular}{|c|}
\hline $\begin{array}{c}\text { Discharge } \\
\left(f t^{3} / \mathrm{s}\right) \\
\end{array}$ \\
\hline $\begin{array}{l}\text { 7-day } \\
14 \text {-day } \\
30-\text { day }\end{array}$ \\
\hline
\end{tabular}

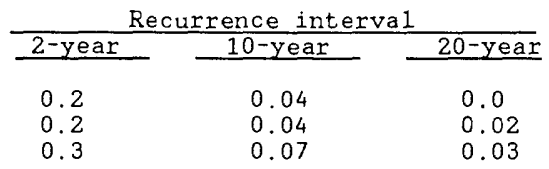

Basis of low-flow estimates:

Correlated with 01483200 , Blackbird Creek at Blackbird, Del.

Number of base-flow observations used - 24 (daily-flow values)

Base-flow observations used, made in 1978-81 (continuous-record station)

Equivalent years of record -- 14

Coefficient of determination $\left(\mathrm{R}^{2}\right) \cdots 0.96$

Standard error of estimate (SE) - 27 percent

Minimum observed discharge used in correlation -- $0.04 \mathrm{ft}^{3} / \mathrm{s}$ 
Table 12.--Basin characteristics and low-flow characteristics at partial-record streamflow-gaging stations in Maryland and Delaware--Continued

01483150 Wiggins Millpond Outlet at Tomsend, Del.

Location: Lat $39^{\circ} 24^{\prime} 12^{\prime \prime}$, long $75^{\circ} 42^{\prime} 16^{\prime \prime}$, New Castle County, at bridge on State Highway 446 , 0.8 mi northwest of Townsend.

Basin characteristics:

$\begin{array}{lclrr}\text { Drainage area } & 3.82 \mathrm{mi}^{2} & \text { Forest } & 20 & \text { percent } \\ \text { Length } & 2.9 \mathrm{mi} & \text { Precipitation } & 44.5 \text { in. } \\ \text { Slope } & 28.0 \mathrm{ft} / \mathrm{mi} & \text { A Soil } & 0 & \text { percent } \\ \text { Elevation } & 60 & \mathrm{ft} & \text { D Soil } & 14 \text { percent } \\ \text { Storage } & 0.92 \text { percent } & & \end{array}$

Low-flow characteristics:

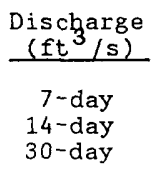

\begin{tabular}{lcc}
\multicolumn{3}{c}{ Recurrence interval } \\
\cline { 1 - 1 } 2 -year & 10-year & 20-year \\
2.4 & 1.1 & 0.8 \\
2.5 & 1.2 & 0.9 \\
2.9 & 1.3 & 1.0
\end{tabular}

Basis of low-flow estimates:

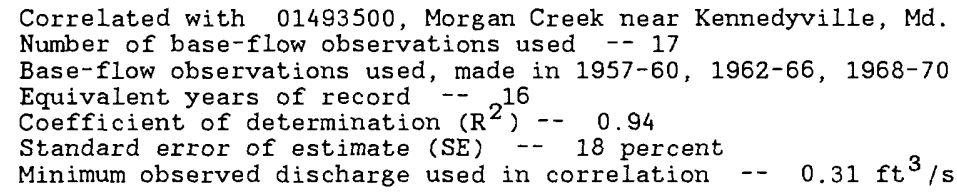

01483300 Providence Creek at Clayton, Del.

Location: Lat $39^{\circ} 18^{\prime} 05^{\prime \prime}$, long $75^{\circ} 38^{\prime} 28^{\prime \prime}$, Kent County, at highway bridge, 0.8 mi north of Clayton.

Basin characteristics:

$\begin{array}{lrllc}\text { Drainage area } & 11.8 \mathrm{mi}^{2} & \text { Forest } & 23 & \text { percent } \\ \text { Length } & 4.7 \mathrm{mi} & \text { Precipitation } & 44.5 \text { in. } \\ \text { Slope } & 12.2 \mathrm{ft} / \mathrm{mi} & \text { A Soil } & 0 & \text { percent } \\ \text { Elevation } & 60 & \mathrm{ft} & \text { D Soil } & 49 \text { percent } \\ \text { Storage } & 0.08 \text { percent } & & \end{array}$

Low-flow characteristics:

$$
\begin{aligned}
& \begin{array}{l}
\text { Discharge } \\
(\mathrm{ft} / \mathrm{s})
\end{array} \\
& \begin{array}{c}
7-\text { day } \\
\text { 14-day } \\
30-\text { day }
\end{array}
\end{aligned}
$$

Basis of low-flow estimates:

Correlated with 01493000, Unicorn Branch near Millington, Md.

Number of base-flow observations used -- 15

Base-flow observations used, made in 1955-58,1960,1962, 1963, 1968,1969

Equivalent years of record --
Coefficient of determination $\left(R^{2}\right)-0.85$

Standard error of estimate (SE) -- 17 percent

Minimum observed discharge used in correlation -- $3.63 \mathrm{ft}^{3} / \mathrm{s}$ 
Table 12.--Basin characteristics and low-flow characteristics at partial-record streamflow-gaging stations in Maryland and Delaware--Continued

01483350 Mill Creek at Smyrna, Del.

Location: Lat $39^{\circ} 17^{\prime} 09^{\prime \prime}$, long $75^{\circ} 36^{\prime} 45^{\prime \prime}$, Kent County, $500 \mathrm{ft}$ above highway bridge, 1 mi south of Smyrna.

Basin characteristics:

$\begin{array}{lclrr}\text { Drainage area } & 4.98 \mathrm{mi}^{2} \text { (Revised) } & \text { Forest } & 9 \text { percent } \\ \text { Length } & 4.9 \mathrm{mi} & \text { Precipitation } & 44.5 \mathrm{in} \text {. } \\ \text { Slope } & 10.8 \mathrm{ft} / \mathrm{mi} & \text { A Soil } & 0 & \text { percent } \\ \text { Elevation } & 52 & \text { D Soil } & 58 \text { percent } \\ \text { Storage } & 0.08 \text { percent } & & \end{array}$

Low-flow characteristics:

$$
\begin{aligned}
& \text { Discharge } \\
& \frac{\left(\mathrm{ft}^{3} / \mathrm{s}\right)}{7-\text { day }} \\
& \begin{array}{l}
\text { 14-day } \\
30-\text { day }
\end{array}
\end{aligned}
$$

Recurrence interval

\begin{tabular}{|c|c|c|}
\hline 2-year & 10 -year & 20 -year \\
\hline $\begin{array}{l}1.6 \\
1.8 \\
1.9\end{array}$ & $\begin{array}{l}1.0 \\
1.1 \\
1.2\end{array}$ & $\begin{array}{l}0.9 \\
0.9 \\
1.0\end{array}$ \\
\hline
\end{tabular}

Basis of low-flow estimates:

Correlated with 01493000, Unicorn Branch near Millington, Md.

Number of base-flow observations used -- 12

Base-flow observations used, made in 1955-58, 1960, 1963,1966, 1969

Equivalent years of record --
Coefficient of determination $\left(R^{2}\right)-0.93$

Standard error of estimate (SE) - 13 percent

Minimum observed discharge used in correlation -- $0.78 \mathrm{ft}^{3} / \mathrm{s}$

01483680 Maidstone Branch at Dupont, Del.

Location: Lat $39^{\circ} 11^{\prime} 18^{\prime \prime}$, long $75^{\circ} 34^{\prime} 04^{\prime \prime}$, Kent County, at highway bridge, 0.4 mi southwest of Dupont.

Basin characteristics:

Drainage area
Length
Slope
Elevation
Storage

$\begin{array}{rl}17.3 & \mathrm{mi}^{2} \\ 8.9 & \mathrm{mi} \\ 5.7 & \mathrm{ft} / \mathrm{mi} \\ 57 & \mathrm{ft} \\ 1.02 & \text { percent }\end{array}$

$\begin{array}{lcl}\text { Forest } & 29 & \text { percent } \\ \text { Precipitation } & 44.5 & \text { in. } \\ \text { A Soil } & 0 & \text { percent } \\ \text { D Soil } & 54 & \text { percent }\end{array}$

Low-flow characteristics:

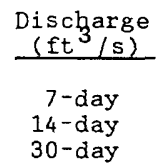

\begin{tabular}{ccc}
\multicolumn{3}{c}{ Recurrence interval } \\
\cline { 1 - 2 } 2-year & 10-year & 20-year \\
1.1 & 0.4 & 0.3 \\
1.3 & 0.4 & 0.3 \\
1.5 & 0.6 & 0.4
\end{tabular}

Basis of low-flow estimates:

Correlated with 01491000 , Choptank River near Greensboro, Md.

Number of base-flow observations used -- 16

Base-flow observations used, made in 1955-57, 1959, 1960, 1962, 1963, 1968,1969

Equivalent years of record - 11

Coefficient of determination $\left(\mathrm{R}^{2}\right)-0.86$

Standard error of estimate (SE) - 37 percent
Minimum observed discharge used in correlation - $0.94 \mathrm{ft}^{3} / \mathrm{s}$ 
Table 12.--Basin characteristics and low-flow characteristics at partial-record streamflow-gaging stations in Maryland and Delaware--Continued

01484020 Browns Branch near Houston, Del.

Location: Lat $38^{\circ} 57^{\prime} 31^{\prime \prime}$, long $75^{\circ} 30^{\prime} 33^{\prime \prime}$, Kent County, at highway bridge, $2.9 \mathrm{mi}$ north of Houston

Basin characteristics:

$\begin{array}{lrl}\text { Drainage area } & 12.4 & \mathrm{mi}^{2} \\ \text { Length } & 6.5 & \mathrm{mi} \\ \text { Slope } & 8.2 & \mathrm{ft} / \mathrm{mi} \\ \text { Elevation } & 51 & \mathrm{ft} \\ \text { Storage } & 0.006 \text { percent }\end{array}$

$\begin{array}{lll}\text { Forest } & 36 & \text { percent } \\ \text { Precipitation } & 45.5 & \text { in. } \\ \text { A Soil } & 41 & \text { percent } \\ \text { D Soil } & 54 & \text { percent }\end{array}$

Low-flow characteristics:

Discharge
$\frac{\left.\mathrm{ft}^{3} / \mathrm{s}\right)}{7-\text { day }}$
$\begin{aligned} & 14-\text { day } \\ & 30-\text { day }\end{aligned}$

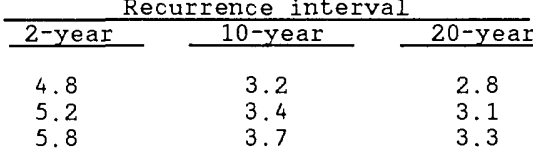

Basis of low-flow estimates:

Correlated with 01484000, Murderkil1 River near Felton, Del.

Number of base-flow observations used -- 20

Base-flow observations used, made in 1955-57, 1959-69

Equivalent years of record -- ${ }^{2}{ }^{14}{ }^{a} 0.95$

Coefficient of determination $\left(\mathrm{R}^{2}\right)-\mathrm{a}_{11} 0.95$

Minimum observed discharge used in correlation -- $4.03 \mathrm{ft}^{3} / \mathrm{s}$

a From linear relation, prior to final graphical fit.

01484040 Hudson Branch near Canterbury, Del.

Location: Lat $39^{\circ} 01^{\prime} 56^{\prime \prime}$, long $75^{\circ} 31^{\prime} 30^{\prime \prime}$, Kent County, at highway bridge, $1.8 \mathrm{mi}$ southeast of Canterbury.

Basin characteristics:

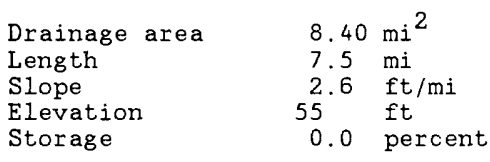

$\begin{array}{lll}\text { Forest } & 32 & \text { percent } \\ \text { Precipitation } & 45.0 \text { in. } \\ \text { A Soil } & 10 & \text { percent } \\ \text { D Soil } & 46 & \text { percent }\end{array}$

Low-flow characteristics:

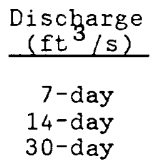

\begin{tabular}{|c|c|c|}
\hline 2-year & 0 -year & 20 -year \\
\hline 4.0 & 2.5 & 2.2 \\
\hline 4.3 & 2.7 & 2.4 \\
\hline 4.6 & 3.0 & 2.7 \\
\hline
\end{tabular}

\section{Basis of low-flow estimates:}

Correlated with 01491000 , Choptank River near Greensboro, Md.

Number of base-flow observations used -- 8

Base-flow observations used, made in 1955-58, 1960

Equivalent years of record -- 6

Coefficient of determination $\left(\mathrm{R}^{2}\right)--0.87$

Standard error of estimate (SE) - 13 percent

Minimum observed discharge used in correlation -- $4.82 \mathrm{ft}^{3} / \mathrm{s}$ 
Table 12.--Basin characteristics and low-flow characteristics at partial-reocrd streamflow-gaging stations in Maryland and Delaware--Continued

01484050 Pratt Branch near Felton, De1.

Location: Lat $39^{\circ} 00^{\prime} 37^{\prime \prime}$, long $75^{\circ} 31^{\prime} 46^{\prime \prime}$, Kent County, at highway bridge, 2.6 mi east of Felton.

Basin characteristics:

Drainage area
Length
Slope
Elevation
Storage

$\begin{array}{ll}3.29 \mathrm{mi}^{2} \\ 3.0 \mathrm{mi} \\ 12.3 \mathrm{ft} / \mathrm{mi} \\ 54 & \mathrm{ft} \\ 0.0 & \text { percent }\end{array}$

Forest

Precipitation 45.0 in.

A Soil 0 percent

D Soil 14 percent

Low-flow characteristics:

\begin{tabular}{|c|c|c|}
\hline 2 -year & 10-year & 20 -year \\
\hline 0.9 & 0.4 & 0.3 \\
\hline 0.9 & 0.5 & 0.4 \\
\hline 1.0 & 0.5 & 0.5 \\
\hline
\end{tabular}

Basis of low-flow estimates:

Correlated with 01484100 , Beaverdam Branch at Houston, Del.

Number of base-flow observations used -- 14

Base-flow observations used, made in 1958-60, 1963-65, 1967-69

Equivalent years of record - ${ }^{9}$

Coefficient of determination $\left(R^{2}\right)-0.92$

Standard error of estimate (SE) - 15 percent

Minimum observed discharge used in correlation -- $0.62 \mathrm{ft}^{3} / \mathrm{s}$

01484060 Double Rum near Magnolia, Del.

Location: Lat $39^{\circ} 03^{\prime} 16^{\prime \prime}$, long $75^{\circ} 29^{\prime} 43^{\prime \prime}$, Kent County, at highway bridge, $1.5 \mathrm{mi}$ southwest of Magnolia.

Basin characteristics:

Drainage area
Length
Slope
Elevation
Storage

$\begin{array}{cl}5.68 \mathrm{mi}^{2} \\ 4.7 & \mathrm{mi} \\ 10.7 & \mathrm{ft} / \mathrm{mi} \\ 44 & \mathrm{ft} \\ 0.0 & \text { percent }\end{array}$

Forest

25 percent

A Soil

D Soil

$45.0 \mathrm{in}$.

0 percent

Storage

0.0 percent

Low-flow characteristics:

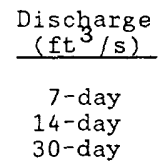

\begin{tabular}{lcc}
\multicolumn{3}{c}{ Recurrence interval } \\
2-year & 10-year & 20-year \\
2.0 & 1.4 & 1.2 \\
2.1 & 1.4 & 1.3 \\
2.2 & 1.5 & 1.4
\end{tabular}

\section{Basis of low-flow estimates:}

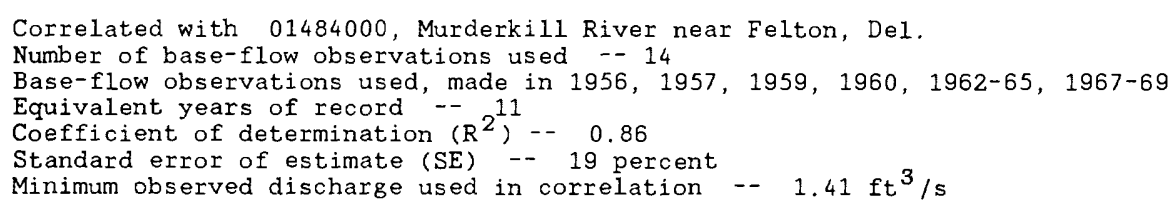


Table 12.--Basin characteristics and low-flow characteristics at partial-record streamflow-gaging stations in Maryland and Delaware--Continued

01484200 Cedar Creek near Lincoln, Del.

Location: Lat $38^{\circ} 51^{\prime} 03^{\prime \prime}$, long $75^{\circ} 25^{\prime} 05^{\prime \prime}$, Sussex County, at highway bridge, 1.2 mi south of Lincoln.

Basin characteristics:

$\begin{array}{lclll}\text { Drainage area } & 7.21 \mathrm{mi}^{2} & \text { Forest } & 49 \text { percent } \\ \text { Length } & 5.0 \mathrm{mi} & \text { Precipitation } & 46.0 \text { in. } \\ \text { Slope } & 4.7 \mathrm{ft} / \mathrm{mi} & \text { A Soil } & 40 & \text { percent } \\ \text { Elevation } & 45 \mathrm{ft} & \text { D Soil } & 24 \text { percent } \\ \text { Storage } & 0.0 \text { percent } & & \end{array}$

Low-flow characteristics:

$$
\begin{aligned}
& \text { Discharge } \\
& \left(\mathrm{ft}^{3} / \mathrm{s}\right) \\
& \text { 7-day } \\
& \text { 14-day } \\
& \text { 30-day }
\end{aligned}
$$

Basis of low-flow estimates:

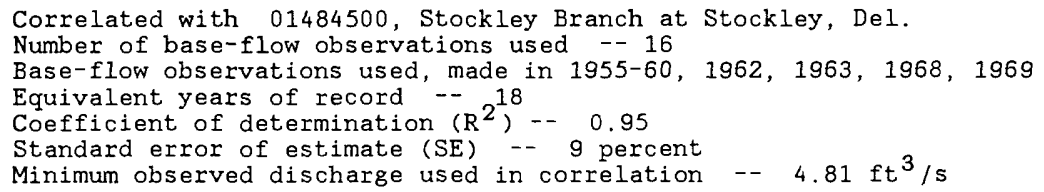

\begin{tabular}{|c|c|c|}
\hline 2-year & 10 -year & 20-year \\
\hline $\begin{array}{l}6.3 \\
6.5 \\
6.7\end{array}$ & $\begin{array}{l}3.5 \\
3.7 \\
4.1\end{array}$ & $\begin{array}{l}2.8 \\
3.1 \\
3.5\end{array}$ \\
\hline
\end{tabular}

01484240 Pemberton Branch near Milton, Del.

Location: Lat $38^{\circ} 46^{\prime} 26^{\prime \prime}$, long $75^{\circ} 20^{\prime} 29^{\prime \prime}$, Sussex County, at highway bridge, $1.5 \mathrm{mi}$ west of Milton.

Basin characteristics

$\begin{array}{lc}\text { Drainage area } & 6.68 \mathrm{mi}^{2} \\ \text { Length } & 4.4 \mathrm{mi} \\ \text { Slope } & 6.6 \mathrm{ft} / \mathrm{mi} \\ \text { Elevation } & 42 \quad \mathrm{ft} \\ \text { Storage } & 5.42 \text { percent }\end{array}$

$\begin{aligned} & \text { Discharge } \\ & \left(\mathrm{ft}^{3} / \mathrm{s}\right)\end{aligned}$
$\begin{gathered}\text { 7-day } \\ 14-\text { day } \\ 30-\text { day }\end{gathered}$

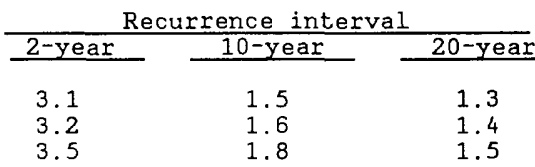

Basis of low-flow estimates:

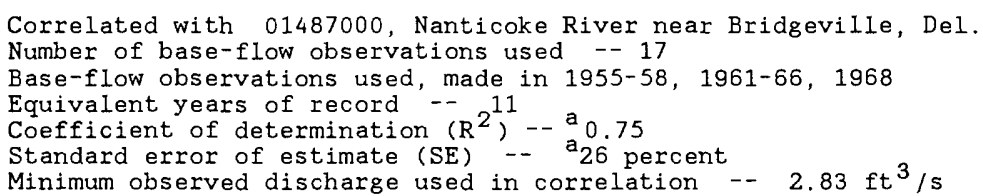

a From linear relation, prior to final graphical fit. 
Table 12.--Basin characteristics and low-flow characteristics at partial-record streamflow-gaging stations in Maryland and Delaware--Continued

01484270 Beaverdan Creek near Milton, Del.

Location: Lat $38^{\circ} 45^{\prime} 41^{\prime \prime}$, long $75^{\circ} 16^{\prime} 03^{\prime \prime}$, Sussex County, at highway culvert, $2.3 \mathrm{mi}$ east of Milton.

Basin characteristics:

$\begin{array}{lc}\text { Drainage area } & 6.10 \mathrm{mi}^{2} \\ \text { Length } & 5.5 \mathrm{mi} \\ \text { Slope } & 7.3 \mathrm{ft} / \mathrm{mi} \\ \text { Elevation } & 34.5 \mathrm{ft} \\ \text { Storage } & 1.67 \text { percent }\end{array}$

$\begin{array}{lcl}\text { Forest } & 56 & \text { percent } \\ \text { Precipitation } & 46.5 & \text { in. } \\ \text { A Soil } & 82 & \text { percent } \\ \text { D Soil } & 1 & \text { percent }\end{array}$

Low-flow characteristics:

$$
\begin{aligned}
& \text { Discharge } \\
& \text { 7-day } \\
& \text { 14-day } \\
& \text { 30-day }
\end{aligned}
$$

\begin{tabular}{|c|c|c|}
\hline 2-year & 10 -year & 20 -yea \\
\hline $\begin{array}{l}6.3 \\
6.5 \\
6.7\end{array}$ & $\begin{array}{l}4.5 \\
4.6 \\
4.8\end{array}$ & $\begin{array}{l}4.0 \\
4.1 \\
4.4\end{array}$ \\
\hline
\end{tabular}

Recurrence interval

Basis of low-flow estimates:

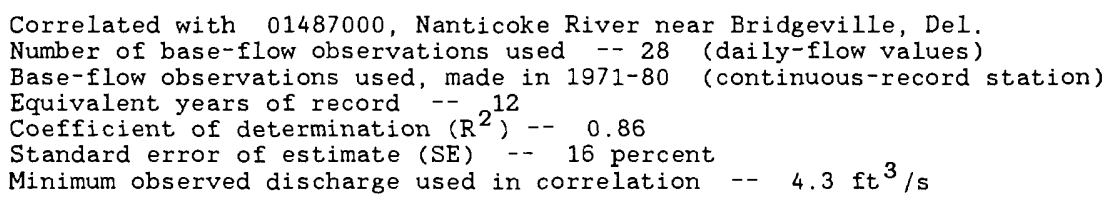

01484550 Pepper Creek at Dagsboro, Del.

Location: Lat $38^{\circ} 32^{\prime} 50^{\prime \prime}$, long $75^{\circ} 14^{\prime} 40^{\prime \prime}$, Sussex County, at bridge on State Highway 26 , at Dagsboro.

Basin characteristics:

$\begin{array}{lclcr}\text { Drainage area } & 8.78 \mathrm{mi}^{2} & \text { Forest } & 48 & \text { percent } \\ \text { Length } & 6.7 \mathrm{mi} & \text { Precipitation } & 47.5 \text { in. } \\ \text { Slope } & 5.4 \mathrm{ft} / \mathrm{mi} & \text { A Soil } & 6 & \text { percent } \\ \text { Elevation } & 35 \mathrm{ft} & \text { D Soil } & 93 & \text { percent } \\ \text { Storage } & 0.08 \text { percent } & & \end{array}$

\section{Low-flow characteristics:}

$$
\begin{gathered}
\begin{array}{c}
\text { Discharge } \\
\text { (ft }
\end{array} \\
\begin{array}{c}
\text { 7-day } \\
\text { 14-day }
\end{array} \\
30-\text { day }
\end{gathered}
$$$$
\text { A Soil }
$$$$
6 \text { percent }
$$

\begin{tabular}{lcc}
\multicolumn{3}{c}{ Recurrence interval } \\
\cline { 1 - 1 } 2-year & 10-year & 20-year \\
1.2 & 0.7 & 0.6 \\
1.3 & 0.7 & 0.6 \\
1.5 & 0.8 & 0.7
\end{tabular}

\section{Basis of low-flow estimates:}

Correlated with 01485000 , Pocomoke River near Willards, Md.

Number of base-flow observations used - 23

Base-flow observations used, made in 1955-58, 1960, 1962-69

Equivalent years of record -- 15

Coefficient of determination $\left(R^{2}\right)--0.90$

Standard error of estimate (SE) -- 25 percent

Minimum observed discharge used in correlation -- $0.79 \mathrm{ft}^{3} / \mathrm{s}$ 
Table 12.--Basin characteristics and low-flow characteristics at partial-record streamflow-gaging stations in Maryland and Delaware--Continued

01484700 Bearhole Ditch at Bunting, Del.

Location: Lat $38^{\circ} 28^{\prime} 17^{\prime \prime}$, long $75^{\circ} 09^{\prime} 22^{\prime \prime}$, Sussex County, at culvert on road No. $390 \mathrm{~A}$, $0.6 \mathrm{mi}$ north of Bunting.

Basin characteristics:

$\begin{array}{lr}\text { Drainage area } & 6.4 \mathrm{mi}^{2} \\ \text { Length } & 4.6 \mathrm{mi} \\ \text { Slope } & 17.9 \mathrm{ft} / \mathrm{mi} \\ \text { Elevation } & 32 \mathrm{ft} \\ \text { Storage } & 8.72 \mathrm{percent}\end{array}$

$\begin{array}{lcl}\text { Forest } & 31 & \text { percent } \\ \text { Precipitation } & 47.5 & \text { in. } \\ \text { A Soil } & 9 & \text { percent } \\ \text { D Soil } & 91 & \text { percent }\end{array}$

Low-flow characteristics:

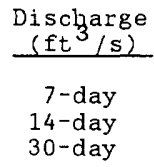

\begin{tabular}{|c|c|c|}
\hline 2-year & 10 -year & 20 -year \\
\hline 1.0 & 0.3 & 0.2 \\
\hline 1.0 & 0.3 & 0.2 \\
\hline 1.1 & 0.4 & 0.3 \\
\hline
\end{tabular}

Basis of low-flow estimates:

Correlated with 01484500, Stockley Branch at Stockley, Del.

Number of base-flow observations used -- 9

Base-flow observations used, made in 1969, 1970, 1985-87

Equivalent years of record --
Coefficient of determination $\left(R^{2}\right)--0.92$

Standard error of estimate (SE) - - 27 percent

Minimum observed discharge used in correlation -- $0.60 \mathrm{ft}^{3} / \mathrm{s}$

01486200 Leonard Pond Rum near Delmar, Md.

Location: Lat $38^{\circ} 25^{\prime} 24^{\prime \prime}$, Iong $75^{\circ} 33^{\prime} 56^{\prime \prime}$, Wicomico County, Leonard Pond, $0.6 \mathrm{mi}$ above Wood Creek, $2.4 \mathrm{mi}$ southeast of Delmar.

Basin characteristics:

\begin{tabular}{|c|c|c|c|c|c|}
\hline $\begin{array}{l}\text { Drainage area } \\
\text { Length } \\
\text { Slope } \\
\text { Elevation }\end{array}$ & $\begin{array}{r}13.4 \\
6.2 \\
7.2 \\
52\end{array}$ & $\begin{array}{l}\mathrm{mi}^{2} \\
\mathrm{mi} \\
\mathrm{ft} / \mathrm{mi} \\
\mathrm{ft}\end{array}$ & $\begin{array}{l}\text { Forest } \\
\text { Precipitation } \\
\text { A Soil } \\
\text { D Soil }\end{array}$ & $\begin{array}{l}52 \\
47.0 \\
2 \\
25\end{array}$ & $\begin{array}{l}\text { percent } \\
\text { in. } \\
\text { percent } \\
\text { percent }\end{array}$ \\
\hline
\end{tabular}

Low-flow characteristics:

$$
\begin{gathered}
\begin{array}{c}
\text { Discharge } \\
\left(\mathrm{ft}^{3} / \mathrm{s}\right)
\end{array} \\
\begin{array}{c}
7-\text { day } \\
14-\text { day } \\
30-\text { day }
\end{array}
\end{gathered}
$$

\begin{tabular}{|c|c|c|}
\hline 2-year & 10 -year & 20-year \\
\hline 2.2 & 1.2 & 1.0 \\
\hline 2.3 & 1.3 & 1.1 \\
\hline 2.6 & 1.4 & 1.2 \\
\hline
\end{tabular}

A Soil

$\begin{aligned} 2 & \text { percent } \\ 25 & \text { percent }\end{aligned}$

Basis of low-flow estimates:

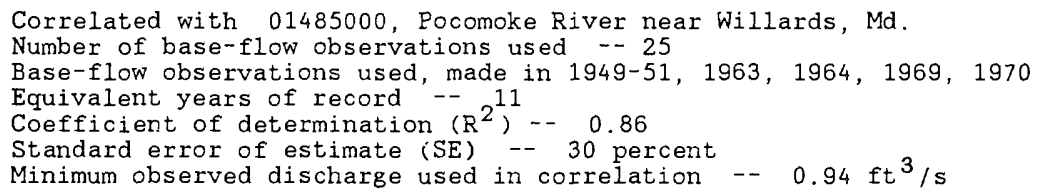


Table 12.--Basin characteristics and low-flow characteristics at partial-record streamflow-gaging stations in Maryland and Delaware--Continued

01487100 Deep Creek at Old Furnace, Del.

Location: Lat $38^{\circ} 40^{\prime} 01^{\prime \prime}$, long $75^{\circ} 31^{\prime} 02^{\prime \prime}$, Sussex County, at highway bridge, at Old Furnace.

Basin characteristics:

$\begin{array}{lcl}\text { Drainage area } & 33.0 \mathrm{mi}^{2} \\ \text { Length } & 12.1 \mathrm{mi} \\ \text { Slope } & 3.2 \mathrm{ft} / \mathrm{mi} \\ \text { Elevation } & 40 \quad \mathrm{ft} \\ \text { Storage } & 5.49 \text { percent }\end{array}$

$\begin{array}{lll}\text { Forest } & 68 & \text { percent } \\ \text { Precipitation } & 47.0 \text { in. } \\ \text { A Soil } & 28 & \text { percent } \\ \text { D Soil } & 64 & \text { percent }\end{array}$

Low-flow characteristics:

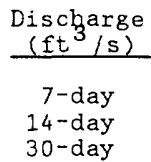

\begin{tabular}{|c|c|c|}
\hline 2-year & 10 -year & 20 -year \\
\hline $\begin{array}{l}6.1 \\
6.5 \\
7.2\end{array}$ & $\begin{array}{l}2.8 \\
3.0 \\
3.4\end{array}$ & $\begin{array}{l}2.2 \\
2.4 \\
2.8\end{array}$ \\
\hline
\end{tabular}

Basis of low-flow estimates:

Correlated with 01487000, Nanticoke River near Bridgeville, Del.

Number of base-flow observations used -- 13

Base-flow observations used, made in 1955-58,1960, 1963, 1968

Equivalent years of record -- ${ }^{14}$ - a ${ }^{14} 0.90$

Standard error of estimate (SE) - $a_{16}$ percent

Minimum observed discharge used in correlation -- $10.2 \mathrm{ft}^{3} / \mathrm{s}$

a From linear relation, prior to final graphical fit.

01487120 Tyndall Branch near Hardscrabble, Del.

Location: Lat $38^{\circ} 37^{\prime} 54^{\prime \prime}$, long $75^{\circ} 29^{\prime} 30^{\prime \prime}$, Sussex County, highway bridge, $1.4 \mathrm{mi}$ northeast of Hardscrabble.

Basin characteristics:

$\begin{array}{lrlll}\text { Drainage area } & 12.3 \mathrm{mi}^{2} \text { (Revised) } & \text { Forest } & 57 & \text { percent } \\ \text { Length } & 5.4 \mathrm{mi} & \text { Precipitation } & 45.5 \text { in. } \\ \text { Slope } & 2.8 \mathrm{ft} / \mathrm{mi} & \text { A Soil } & 32 & \text { percent } \\ \text { Elevation } & 46 & \mathrm{ft} & \text { D Soil } & 52 \text { percent } \\ \text { Storage } & 1.79 \text { percent } & & & \end{array}$

Low-flow characteristics:

$$
\frac{\begin{array}{c}
\text { Discharge } \\
\left(\mathrm{ft}^{3} / \mathrm{s}\right)
\end{array}}{\begin{array}{c}
7 \text {-day } \\
\text { 14-day } \\
30-\text { day }
\end{array}}
$$

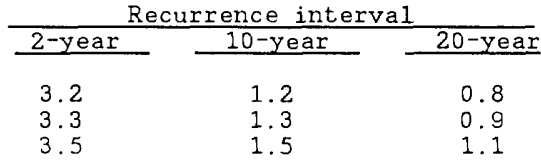

\section{Basis of low-flow estimates:}

Correlated with 01484500, Stockley Branch at Stockley, Del.

Number of base-flow observations used -- 19

Base-flow observations used, made in 1955-63, 1966

Equivalent years of record - 13

Coefficient of determination $\left(\mathrm{R}^{2}\right)-0.85$

Standard error of estimate (SE) -- 24 percent

Minimum observed discharge used in correlation -- $2.58 \mathrm{ft}^{3} / \mathrm{s}$ 
Table 12.--Basin characteristics and low-flow characteristics at partial-record streamflow-gaging stations in Maryland and Delaware--Continued

01487300 Butler Mill Branch near Woodland, Del.

Location: Lat $38^{\circ} 37^{\prime} 56^{\prime \prime}$, long $75^{\circ} 39^{\prime} 35^{\prime \prime}$, Sussex County, at highway bridge 2.2 mi north of Woodland.

Basin characteristics:

$\begin{array}{lc}\text { Drainage area } & 6.85 \mathrm{mi}^{2} \text { (Revised) } \\ \text { Length } & 4.8 \mathrm{mi} \\ \text { Slope } & 5.4 \mathrm{ft} / \mathrm{mi} \\ \text { Elevation } & 42 \quad \mathrm{ft} \\ \text { Storage } & 0.56 \text { percent }\end{array}$

$\begin{array}{lll}\text { Forest } & 27 & \text { percent } \\ \text { Precipitation } & 46.0 \text { in. } \\ \text { A Soil } & 20 & \text { percent } \\ \text { D Soil } & 32 & \text { percent }\end{array}$

Low-flow characteristics:

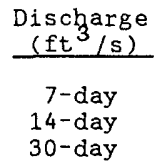

\begin{tabular}{lcc}
\multicolumn{3}{c}{ Recurrence interval } \\
\cline { 1 - 2 } 2-year & 10-year & 20-year \\
2.2 & 1.3 & 1.1 \\
2.3 & 1.3 & 1.1 \\
2.5 & 1.4 & 1.2
\end{tabular}

Basis of low-flow estimates:

Correlated with 01487000, Nanticoke River near Bridgeville, Del.

Number of base-flow observations used -- 17

Base-flow observations used, made in 1955-63, 1966

Equivalent years of record -- 16

Coefficient of determination $\left(\mathrm{R}^{2}\right)-0.92$

Standard error of estimate (SE) -- 17 percent

Minimum observed discharge used in correlation -- $1.87 \mathrm{ft}^{3} / \mathrm{s}$

01487700 Elliott Pond Branch near Laurel, Del.

Location: Lat $38^{\circ} 34^{\prime} 39^{\prime \prime}$, long $75^{\circ} 31^{\prime} 42^{\prime \prime}$, Sussex County, at highway bridge, 2.9 mi northwest of Laurel.

Basin characteristics:

$\begin{array}{lclll}\text { Drainage area } & 8.55 \mathrm{mi}^{2} & \text { Forest } & 42 & \text { percent } \\ \text { Length } & 5.6 \mathrm{mi} & \text { Precipitation } & 46.5 \text { in. } \\ \text { Slope } & 5.7 \mathrm{ft} / \mathrm{mi} & \text { A Soil } & 52 & \text { percent } \\ \text { Elevation } & 41 & \text { D Soil } & 44 \text { percent } \\ \text { Storage } & 1.67 \text { percent } & & \end{array}$

Low-flow characteristics:

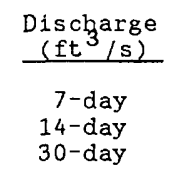

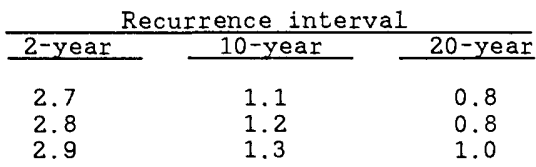

Basis of low-flow estimates:

Correlated with 01484500, Stockley Branch at Stockley, Del.

Number of base-flow observations used - 24

Base-flow observations used, made in 1955-63, 1965, 1966, 1968, 1969

Equivalent years of record -- 13

Coefficient of determination $\left(R^{2}\right)--0.77$

Standard error of estimate (SE) -- 30 percent

Minimum observed discharge used in correlation -- $1.90 \mathrm{ft}^{3} / \mathrm{s}$ 
Table 12.--Basin characteristics and low-flow characteristics at partial-record streamflow-gaging stations in Maryland and Delaware--Continued

01489395 Chicone Creek at Reids Grove, Hd.

Location: Lat $38^{\circ} 31^{\prime} 55^{\prime \prime}$, long $75^{\circ} 49^{\prime} 06^{\prime \prime}$, Dorchester County, at county road bridge, $1 / 2$ mi east of Reids Grove.

Basin characteristics:

$\begin{array}{lcl}\text { Drainage area } & 4.69 \mathrm{mi}^{2} \\ \text { Length } & 3.4 \mathrm{mi} \\ \text { Slope } & 8.2 \mathrm{ft} / \mathrm{mi} \\ \text { Elevation } & 30 & \mathrm{ft} \\ \text { Storage } & 0.0 \text { percent }\end{array}$

$\begin{array}{lcl}\text { Forest } & 60 & \text { percent } \\ \text { Precipitation } & 46.0 & \text { in. } \\ \text { A Soil } & 0 & \text { percent } \\ \text { D Soil } & 41 & \text { percent }\end{array}$

Low-flow characteristics:

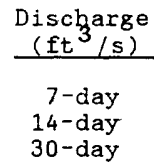

Basis of low-flow estimates:

Correlated with 01487000, Nanticoke River near Bridgeville, Del.

Number of base-flow observations used - 19

Base-flow observations used, made in 1950-52, 1970

Equivalent years of record -- 16

Coefficient of determination $\left(R^{2}\right)-0.93$

Standard error of estimate (SE) -- 30 percent

Minimum observed discharge used in correlation -- $0.46 \mathrm{ft}^{3} / \mathrm{s}$

01489400 Baron Creek at Md.-Del. State Corner, Md.

Location: Lat $38^{\circ} 27^{\prime} 30^{\prime \prime}$, long $75^{\circ} 42^{\prime} 00^{\prime \prime}$, Wicomico County, at coounty road, $0.3 \mathrm{mi}$ west Md.-Del. State corner.

Basin characteristics:

Drainage area

Length

Slope

Elevation

Storage

$\begin{array}{ll}8.9 & \mathrm{mi}^{2} \\ 5.2 & \mathrm{mi} \\ 5.3 & \mathrm{ft} / \mathrm{mi} \\ 45 & \mathrm{ft} \\ 0.54 & \text { percent }\end{array}$

Recurrence interval

\begin{tabular}{|c|c|c|}
\hline 2-year & 10 -year & 20 -year \\
\hline $\begin{array}{l}0.5 \\
0.5 \\
0.6\end{array}$ & $\begin{array}{l}0.2 \\
0.3 \\
0.3\end{array}$ & $\begin{array}{l}0.2 \\
0.2 \\
0.2\end{array}$ \\
\hline
\end{tabular}

Low-flow characteristics:

$$
\begin{gathered}
\begin{array}{c}
\text { Discharge } \\
\left(\mathrm{ft}^{3} / \mathrm{s}\right)
\end{array} \\
\begin{array}{c}
7 \text {-day } \\
14-\text { day } \\
30-\text { day }
\end{array}
\end{gathered}
$$

$\begin{array}{lll}\text { Forest } & 5 & \text { percent } \\ \text { Precipitation } & 46.0 & \text { in. } \\ \text { A Soil } & 23 & \text { percent } \\ \text { D Soil } & 23 & \text { percent }\end{array}$

Basis of low-flow estimates:

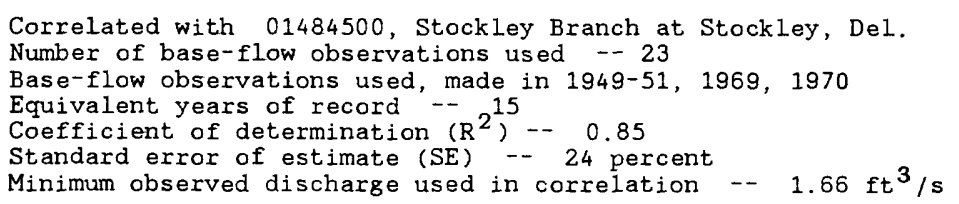


Table 12.--Basin characteristics and low-flow characteristics at partial-record streamflow-gaging stations in Maryland and Delaware--Continued

01489500 Rewastico Creek near Hebron, Md.

Location: Lat $38^{\circ} 24^{\prime} 40^{\prime \prime}$, long $75^{\circ} 45^{\prime} 15^{\prime \prime}$, Wicomico County, on wingwall of old mill sluiceway, at outlet of Rewastico Pond, $3.5 \mathrm{mi}$ southwest of Hebron.

Basin characteristics:

$\begin{array}{lrllcc}\text { Drainage area } & 12.2 \mathrm{mi}^{2} & \text { Forest } & 44 & \text { percent } \\ \text { Length } & 8.2 \mathrm{mi} & \text { Precipitation } & 46.5 \text { in. } \\ \text { Slope } & 6.2 \mathrm{ft} / \mathrm{mi} & \text { A Soil } & 4 & \text { percent } \\ \text { Elevation } & 37 & \mathrm{ft} & \text { D Soil } & 48 & \text { percent } \\ \text { Storage } & 3.84 \text { percent } & & & \end{array}$

Low-flow characteristics:

\begin{tabular}{c} 
Discbarge \\
$(\mathrm{ft} / \mathrm{s})$ \\
\hline $\begin{array}{c}7-\text { day } \\
14-\text { day } \\
30-\text { day }\end{array}$
\end{tabular}

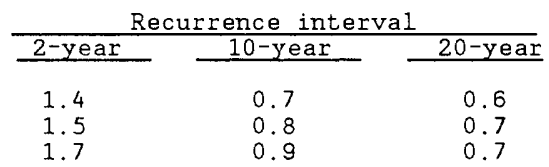

\section{Basis of low-flow estimates:}

Correlated with 01485000, Pocomoke River near Willards, Md.

Number of base-flow observations used -- 23 (daily-flow values)

Base-flow observations used, made in 1951-56 (continuous-record station)

Equivalent years of record -- 11

Coefficient of determination $\left(\mathrm{R}^{2}\right)-0.81$

Standard error of estimate (SE) -- 32 percent

Minimum observed discharge used in correlation - $1.2 \mathrm{ft}^{3} / \mathrm{s}$

01491060 Forge Branch at Greensboro, Md.

Location: ${ }^{a}$ Lat $38^{\circ} 59^{\prime} 07^{\prime \prime}$, long $75^{\circ} 49^{\prime} 00^{\prime \prime}$, Caroline County, at bridge on county road, 1 mi northwest of Greensboro.

\section{Basin characteristics:}

Drainage area
Length
Slope
Elevation
Storage

$9.84 \mathrm{mi}^{2}$
$4.2 \mathrm{mi}$
$7.7 \mathrm{ft} / \mathrm{mi}$
$52 \mathrm{ft}$
0.007 percent

$\begin{array}{lrl}\text { Forest } & 31 & \text { percent } \\ \text { Precipitation } & 45.0 & \text { in. } \\ \text { A Soil } & 0 & \text { percent } \\ \text { D Soil } & 52 & \text { percent }\end{array}$

Low-flow characteristics:

Discharge
$\left(\mathrm{ft}^{3} / \mathrm{s}\right)$
$\begin{gathered}7-\text { day } \\ 14-\text { day } \\ 30-\text { day }\end{gathered}$

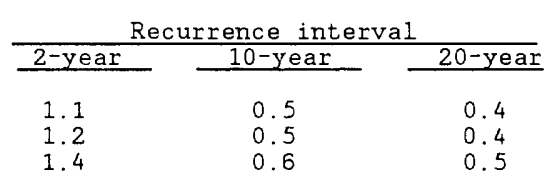

Basis of low-flow estimates:

Correlated with 01488500, Marshyhope Creek near Adamsville, Del.

Number of base-flow observations used -- 9

Base-flow observations used, made in 1951-52

Equivalent years of record -- 10

Coefficient of determination $\left(R^{2}\right)-0.94$

Standard error of estimate (SE) - 19 percent

Minimum observed discharge used in correlation -- $2.01 \mathrm{ft}^{3} / \mathrm{s}$

\footnotetext{
a Revised.
} 
Table 12.--Basin characteristics and low-flow characteristics at partial-record streamflow-gaging stations in Maryland and Delaware--Continued

01491180 Watts Creek near Denton, Md.

Location (Revised). Lat $38^{\circ} 52^{\prime} 29^{\prime \prime}$, Long $75^{\circ} 47^{\prime} 32^{\prime \prime}$, Caroline County, at bridge on Hobbs Rd., $1.6 \mathrm{mi}$ southeast of Denton.

Basin characteristics:

Drainage area
Length
Slope
Elevation
Storage

$9.85 \mathrm{mi}^{2}$
$5.2 \mathrm{mi}$
$10.0 \mathrm{ft} / \mathrm{mi}$
$53 \mathrm{ft}$
2.40 percent

$\begin{array}{lcl}\text { Forest } & 44 & \text { percent } \\ \text { Precipitation } & 45.5 & \text { in. } \\ \text { A Soil } & 0 & \text { percent } \\ \text { D Soil } & 40 & \text { percent }\end{array}$

Low-flow characteristics:

Discharge
$\frac{\left(\mathrm{ft}^{3} / \mathrm{s}\right)}{7-\text { day }}$
$\begin{aligned} & \text { 14-day } \\ & 30-\text { day }\end{aligned}$

\begin{tabular}{|c|c|c|}
\hline 2-year & 10-year & 20 -year \\
\hline $\begin{array}{l}0.8 \\
0.9 \\
1.0\end{array}$ & $\begin{array}{l}0.4 \\
0.4 \\
0.5\end{array}$ & $\begin{array}{l}0.3 \\
0.3 \\
0.4\end{array}$ \\
\hline
\end{tabular}

\section{Basis of low-flow estimates:}

Correlated with 01488500, Marshyhope Creek near Adamsville, Del.

Number of base-flow observations used - 8

Base-flow observations used, made in 1964-68 (before extensive ditching in 01491180 drainage basin)

Equivalent years of record -- 12

Coefficient of determination $\left(\mathrm{R}^{2}\right)-0.97$

Standard error of estimate (SE) -- 18 percent

Minimum observed discharge used in correlation - $0.32 \mathrm{ft}^{3} / \mathrm{s}$

\section{Tuckahoe Creek near Ruthsburg, Md.}

Location: Lat $38^{\circ} 58^{\prime} 00^{\prime \prime}$, long $75^{\circ} 56^{\prime} 35^{\prime \prime}$, Queen Annes County, at highway bridge, $2.6 \mathrm{mi}$ south of Ruthsburg.

Basin characteristics:

$\begin{array}{lrllrr}\text { Drainage area } & 85.2 \mathrm{mi}^{2} & \text { Forest } & 36 & \text { percent } \\ \text { Length } & 16.8 \mathrm{mi} & \text { Precipitation } & 44.5 \text { in. } \\ \text { Slope } & 3.6 \mathrm{ft} / \mathrm{mi} & \text { A Soil } & 1 & \text { percent } \\ \text { Elevation } & 62 & \mathrm{ft} & \text { D Soil } & 53 & \text { percent } \\ \text { Storage } & 3.05 \text { percent } & & & \end{array}$

\section{Low-flow characteristics:}

$$
\begin{aligned}
& \text { Discharge } \\
& \text { 7-day } \\
& \text { 14-day } \\
& \text { 30-day }
\end{aligned}
$$

\begin{tabular}{lcc}
\multicolumn{3}{c}{ Recurrence interval } \\
\cline { 1 - 1 } 2 2-year & 10-year & 20-year \\
20 & 11 & 8.8 \\
23 & 12 & 9.8 \\
25 & 13 & 11
\end{tabular}

\section{Basis of low-flow estimates:}

Correlated with 01493000 , Unicorn Branch near Millington, Md.

Number of base-flow observations used -- 18 (daily-flow values)

Base-flow observations used, made in 1951-56 (continuous-record station)

Equivalent years of record -- 17

Coefficient of determination $\left(R^{2}\right)-0.94$

Standard error of estimate (SE) - 14 percent

Minimum observed discharge used in correlation -- $14 \mathrm{ft}^{3} / \mathrm{s}$ 
Table 12.--Basin characteristics and low-flow characteristics at partial-record streamflow-gaging stations in Maryland and Delaware--Continued

\section{Knott Millpond near Hillsboro, Md.}

Location: Lat $38^{\circ} 52^{\prime} 54^{\prime \prime}$, long $75^{\circ} 55^{\prime} 33^{\prime \prime}$, CAroline County, at bridge on Tuckahoe Road, $2.5 \mathrm{mi}$ south of Hillsboro.

\section{Basin characteristics:}

Drainage area
Length
Slope
Elevation
Storage

$\begin{array}{ll}8.45 \mathrm{mi}^{2} \\ 4.7 \mathrm{mi} \\ 7.7 \mathrm{ft} / \mathrm{mi} \\ 49 & \mathrm{ft} \\ 0.0 & \text { percent }\end{array}$

$\begin{array}{lrl}\text { Forest } & 8 & \text { percent } \\ \text { Precipitation } & 41.0 & \text { in. } \\ \text { A Soil } & 0 & \text { percent } \\ \text { D Soil } & 14 & \text { percent }\end{array}$

Low-flow characteristics:

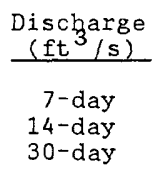

\begin{tabular}{|c|c|c|}
\hline 2 -year & 10 -year & 20 -year \\
\hline $\begin{array}{l}3.5 \\
3.9 \\
4.3\end{array}$ & $\begin{array}{l}1.8 \\
2.0 \\
2.2\end{array}$ & $\begin{array}{l}1.5 \\
1.6 \\
1.8\end{array}$ \\
\hline
\end{tabular}

Basis of low-flow estimates:

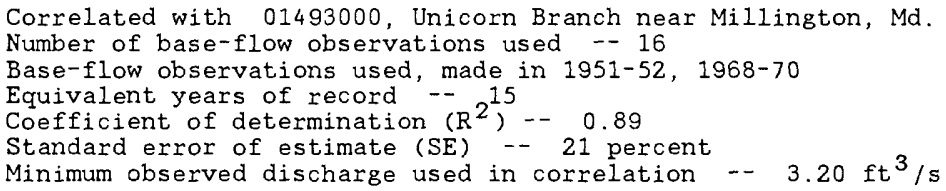

01492080 Cabin Creek at Cabin Creek, Md.

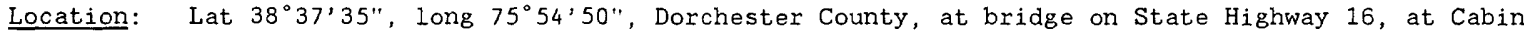
Creek, Md.

Basin characteristics:

Drainage area
Length
Slope
Elevation
Storage

$$
\begin{array}{ll}
6.05 \mathrm{mi}^{2} \\
2.5 \mathrm{mi} \\
10.8 \mathrm{ft} / \mathrm{mi} \\
41 & \mathrm{ft} \\
0.95 & \text { percent }
\end{array}
$$

\begin{tabular}{|c|c|c|}
\hline 2-year & 10 -yeax & 20 -year \\
\hline $\begin{array}{l}4.6 \\
4.8 \\
5.1\end{array}$ & $\begin{array}{l}2.9 \\
3.0 \\
3.2\end{array}$ & $\begin{array}{l}2.5 \\
2.6 \\
2.8\end{array}$ \\
\hline
\end{tabular}

$\begin{array}{lcc}\text { Forest } & 21 & \text { percent } \\ \text { Precipitation } & 45.5 & \text { in. } \\ \text { A Soil } & 3 & \text { percent } \\ \text { D Soil } & 4 & \text { percent }\end{array}$

Low-flow characteristics:

$$
\begin{gathered}
\begin{array}{c}
\text { Discharge } \\
\left(\mathrm{ft}^{3} / \mathrm{s}\right)
\end{array} \\
\begin{array}{c}
7-\text { day } \\
14-\text { day } \\
30-\text { day }
\end{array}
\end{gathered}
$$

\section{Basis of low-flow estimates:}

Correlated with 01487000, Nanticoke River near Bridgeville, Del.

Number of base-flow observations used -- 11

Base-flow observations used, made in 1951-52

$\left.\begin{array}{l}\text { Equivalent years of record }- \\ \text { Coefficient of determination }\left(R^{2}\right)-\ldots \\ a_{0}\end{array}\right) .95$

Standard error of estimate (SE) - $a_{12}$ percent

Minimum observed discharge used in correlation -- $4.35 \mathrm{ft}^{3} / \mathrm{s}$

a From linear relation, prior to final graphical fit. 
Table 12.--Basin characteristics and low-flow characteristics at partial-record streamflow-gaging stations in Maryland and Delaware--Continued

01492500 Sallie Harris Creek near Carmichael, Md.

Location: Lat $38^{\circ} 57^{\prime} 55^{\prime \prime}$, long $76^{\circ} 06^{\prime} 30^{\prime \prime}$, Queen Annes County, 30 ft upstream from bridge on U.S. Highway $50,2.0 \mathrm{mi}$ northeast of Carmichael.

Basin characteristics:

Drainage area
Length
Slope
Elevation
Storage

$$
\begin{array}{cl}
8.09 \mathrm{mi}^{2} \\
6.1 & \mathrm{mi} \\
8.8 & \mathrm{ft} / \mathrm{mi} \\
59 & \mathrm{ft} \\
0.0 & \text { percent }
\end{array}
$$

$\begin{array}{lcl}\text { Forest } & 32 & \text { percent } \\ \text { Precipitation } & 44.5 & \text { in. } \\ \text { A Soil } & 0 & \text { percent } \\ \text { D Soil } & 15 & \text { percent }\end{array}$

Low-flow characteristics:

$$
\frac{\begin{array}{l}
\text { Discharge } \\
\left(\mathrm{ft}^{3} / \mathrm{s}\right)
\end{array}}{\begin{array}{c}
7-\text { day } \\
14-\text { day } \\
30-\text { day }
\end{array}}
$$

$\begin{array}{lccc}2 \text { 2-year } & \frac{10 \text {-year }}{n n n} 2.0 & & \text { 20-year } \\ 2.2 & 1.2 & & 1.0 \\ 2.4 & 1.3 & 1.1 \\ & 1.4 & & 1.2\end{array}$

Basis of low-flow estimates:

Correlated with 01493000, Unicorn Branch near Millington, Md.

Number of base-flow observations used -- 23 (daily-flow values)

Base-flow observations used, made in 1951-56 (continuous-record station)

Equivalent years of record --
Coefficient of determination $\left(\mathrm{R}^{2}\right)-0.88$

Standard error of estimate (SE) -- 18 percent

Minimum observed discharge used in correlation -- $1.5 \mathrm{ft}^{3} / \mathrm{s}$

01492560 Mi11 Creek near Wye Mi11s, Md.

Location (Revised): Lat 38 $54^{\prime} 53^{\prime \prime}$, long $76^{\circ} 03^{\prime} 50^{\prime \prime}$, Talbot County, below confluence with tributary $500 \mathrm{ft}$ down'tream from bridge on U.S. Highway $50,1.9 \mathrm{mi}$ south of Wye Mills.

Basin characteristics:

Drainage area
Length
Slope
Elevation
Storage

$5.72 \mathrm{mi}^{2}$ (Revised)
$3.5 \mathrm{mi}$
$17.3 \mathrm{ft} / \mathrm{mi}$
$59 \quad \mathrm{ft}$
0.22 percent

$\begin{array}{lcl}\text { Forest } & 14 & \text { percent } \\ \text { Precipitation } & 44.5 & \text { in. } \\ \text { A Soil } & 3 & \text { percent } \\ \text { D Soil } & 20 & \text { percent }\end{array}$

\section{Low-flow characteristics:}

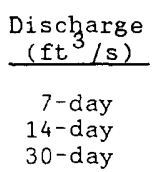

\begin{tabular}{lccc}
\multicolumn{3}{c}{ Recurrence interval } \\
\cline { 1 - 1 } 2 -year & 10-year & 20-year \\
2.8 & 1.8 & & 1.5 \\
3.0 & 1.9 & & 1.7 \\
3.3 & 2.1 & & 1.8
\end{tabular}

Basis of low-flow estimates:

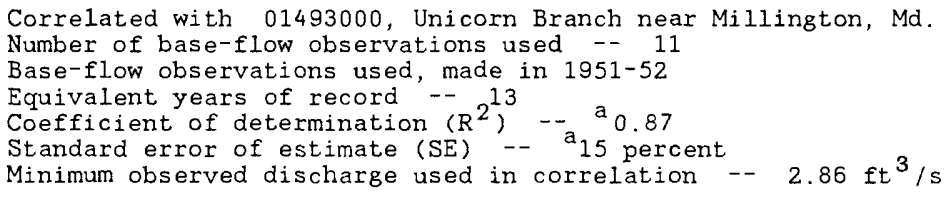

From linear relation, prior to final graphical fit 
Table 12.--Basin characteristics and low-flow characteristics at partial-record streamflow-gaging stations in Maryland and Delaware--Continued

01492980 Cypress Branch at Millington, Md.

Location: Lat $39^{\circ} 15^{\prime} 28^{\prime \prime}$, long $75^{\circ} 50^{\prime} 01^{\prime \prime}$, Kent County, at bridge on State Highway 291 , at Millington.

Basin characteristics:

$\begin{array}{lrl}\text { Drainage area } & 38.5 \mathrm{mi}^{2} \\ \text { Length } & 11.0 \mathrm{mi} \\ \text { Slope } & 5.3 \mathrm{ft} / \mathrm{mi} \\ \text { Elevation } & 54 & \mathrm{ft} \\ \text { Storage } & 5.34 \text { percent }\end{array}$

$\begin{array}{lcl}\text { Forest } & 48 & \text { percent } \\ \text { Precipitation } & 43.5 & \text { in. } \\ \text { A Soil } & 1 & \text { percent } \\ \text { D Soil } & 35 & \text { percent }\end{array}$

Low-flow characteristics:

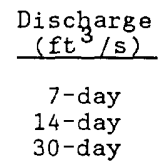

\begin{tabular}{|c|c|c|}
\hline 2-year & 10 -year & 20 -year \\
\hline $\begin{array}{l}3.1 \\
3.7 \\
4.3\end{array}$ & $\begin{array}{l}1.1 \\
1.3 \\
1.5\end{array}$ & $\begin{array}{l}0.8 \\
0.9 \\
1.0\end{array}$ \\
\hline
\end{tabular}

Basis of low-flow estimates:

Correlated with 01493000 , Unicorn Branch near Millington, Md.

Number of base-flow observations used -- 16

Base-flow observations used, made in 1964-66, 1958-74

Equivalent years of record -- 10

Coefficient of determination $\left(R^{2}\right)-0.88$

Standard error of estimate (SE) - 40 percent

Minimum observed discharge used in correlation -- $0.62 \mathrm{ft}^{3} / \mathrm{s}$

01492990 Mills Branch near Millington, Md.

Location: Lat $39^{\circ} 16^{\prime} 34^{\prime \prime}$, long $75^{\circ} 52^{\prime} 10^{\prime \prime}$, Kent County, at bridge on Millington Road, 2.1 mi northwest of Millington.

Basin characteristics:

Drainage area
Length
Slope
Elevation
Storage

$$
\begin{array}{ll}
9.98 \mathrm{mi}^{2} \\
4.5 \mathrm{mi} \\
11.9 \mathrm{ft} / \mathrm{mi} \\
65 & \mathrm{ft} \\
0.0 & \text { percent }
\end{array}
$$

$\begin{array}{lcl}\text { Forest } & 27 & \text { percent } \\ \text { Precipitation } & 45.5 & \text { in. } \\ \text { A Soil } & 0 & \text { percent } \\ \text { D Soil } & 22 & \text { percent }\end{array}$

Low-flow characteristics:

$$
\frac{\begin{array}{c}
\text { Discharge } \\
\left(\mathrm{ft}^{3} / \mathrm{s}\right)
\end{array}}{\begin{array}{c}
7-\text { day } \\
14-\text { day } \\
30-\text { day }
\end{array}}
$$

\section{Basis of low-flow estimates:}

\begin{tabular}{ccc}
\multicolumn{3}{c}{ Recurrence interval } \\
\cline { 1 - 1 } 2-year & 10-year & 20-year \\
1.0 & 0.5 & 0.4 \\
1.2 & 0.6 & 0.4 \\
1.3 & 0.6 & 0.5
\end{tabular}

Correlated with 01493000, Unicorn Branch near Millington, Md.

Number of base-flow observations used -- 24

Base-flow observations used, made in 1952-53,1968-70

Equivalent years of record -- 17
Coefficient of determination $\left(R^{2}\right)-0.97$

Standard error of estimate (SE) - 16 percent

Minimum observed discharge used in correlation -- $0.86 \mathrm{ft}^{3} / \mathrm{s}$ 
Table 12.--Basin characteristics and low-flow characteristics at partial-record streamflow-gaging stations in Maryland and Delaware--Continued

01493480 Foreman Branch at Ewingville, Md.

Location: Lat $39^{\circ} 12^{\prime} 39^{\prime \prime}$, long $75^{\circ} 58^{\prime} 59^{\prime \prime}$, Queen Annes County, at bridge on State Highway $544^{\prime} 0.7$ mi north of Ewingville.

Basin characteristics

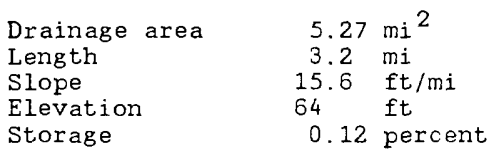

$\begin{array}{lcl}\text { Forest } & 29 & \text { percent } \\ \text { Precipitation } & 43.5 & \text { in. } \\ \text { A Soil } & 0 & \text { percent } \\ \text { D Soil } & 16 & \text { percent }\end{array}$

Low-flow characteristics

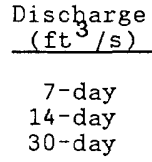

\begin{tabular}{|c|c|c|}
\hline 2-year & 10 -year & 20 -year \\
\hline $\begin{array}{l}1.1 \\
1.2 \\
1.3\end{array}$ & $\begin{array}{l}0.6 \\
0.7 \\
0.7\end{array}$ & $\begin{array}{l}0.5 \\
0.5 \\
0.6\end{array}$ \\
\hline
\end{tabular}

Basis of low-flow estimates:

Correlated with 01493000, Unicorn Branch near Millington, Md.

Number of base-flow observations used -- 17

Base-flow observations used, made in 1952-53

Equivalent years of record --
Coefficient of determination $\left(R^{2}\right)-0.98$

Standard error of estimate (SE) - 10 percent

Minimum observed discharge used in correlation -- $1.34 \mathrm{ft}^{3} / \mathrm{s}$

01494000 Southeast Creek at Church Hi11, Md.

Location: Lat $39^{\circ} 07^{\prime} 57^{\prime \prime}$, long $75^{\circ} 58^{\prime} 51^{\prime \prime}$, Queen Annes County, 10 ft upstream from culvert on private road, $0.7 \mathrm{mi}$ south of Church Hill.

Basin characteristics:

\begin{tabular}{|c|c|c|c|c|c|}
\hline Drainage area & 12.5 & $\mathrm{mi}^{2}$ & Forest & 24 & percent \\
\hline Length & 5.6 & $\mathrm{mi}$ & Precipitation & 44.5 & in. \\
\hline Slope & 10.6 & $\mathrm{ft} / \mathrm{mi}$ & A Soil & 0 & percent \\
\hline Elevation & 67 & ft & D Soil & 40 & percent \\
\hline Storage & 0.008 & percent & & & \\
\hline
\end{tabular}

Low-flow characteristics:

$$
\begin{gathered}
\begin{array}{c}
\text { Discharge } \\
\left(\mathrm{ft}^{3} / \mathrm{s}\right)
\end{array} \\
\begin{array}{c}
7-\text { day } \\
14-\text { day } \\
30-\text { day }
\end{array}
\end{gathered}
$$

\begin{tabular}{ccc}
\multicolumn{3}{c}{ Recurrence interval } \\
\cline { 1 - 1 } 2-year & 10-year & 20-year \\
2.7 & 1.4 & 1.2 \\
3.0 & 1.6 & 1.3 \\
3.3 & 1.8 & 1.4
\end{tabular}

Basis of low-flow estimates:

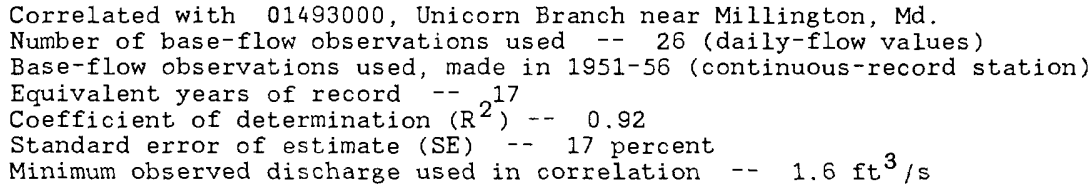


Table 12.--Basin characteristics and low-flow characteristics at partial-record streamflow-gaging stations in Maryland and Delaware--Continued

01494035 Mill Pond Outlet near Langford, Md.

Location: Lat $39^{\circ} 11^{\prime} 16^{\prime \prime}$, long $76^{\circ} 06^{\prime} 58^{\prime \prime}$, Kent County, at spillway of dam, $1.4 \mathrm{mi}$ east of Langford

Basin characteristics:

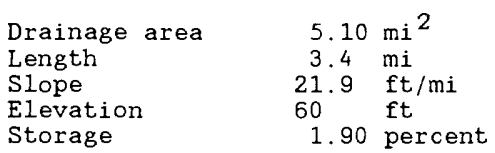

$\begin{array}{lcl}\text { Forest } & 8 & \text { percent } \\ \text { Precipitation } & 44.5 & \text { in. } \\ \text { A Soil } & 0 & \text { percent } \\ \text { D Soil } & 5 & \text { percent }\end{array}$

Low-flow characteristics:

$\begin{gathered}\text { Discharge } \\ \left(\mathrm{ft}^{3} / \mathrm{s}\right)\end{gathered}$
$\begin{gathered}7-\text { day } \\ 14-\text { day } \\ 30-\text { day }\end{gathered}$

\begin{tabular}{lccc}
\multicolumn{3}{c}{ Recurrence interval } \\
\cline { 1 - 1 } 2-year & 10-year & 20-year \\
2.6 & 1.7 & & 1.4 \\
2.7 & 1.7 & & 1.5 \\
3.0 & 1.9 & & 1.6
\end{tabular}

Basis of low-flow estimates:

Correlated with 01493500, Morgan Creek near Kennedyville, Md.

Number of base-flow observations used -- 23

Base-flow observations used, made in 1952-53, 1968-70

Equivalent years of record -- 14

Coefficient of determination $\left(R^{2}\right)-0.93$

Standard error of estimate (SE) -- 11 percent

Minimum observed discharge used in correlation -- $1.48 \mathrm{ft}^{3} / \mathrm{s}$

01494100 Old Mill Stream Branch at Centerville, Md.

Location: Lat $39^{\circ} 02^{\prime} 23^{\prime \prime}$, long $76^{\circ} 04^{\prime} 22^{\prime \prime}$, Queen Annes County, at bridge on U.S. Highway 213 , at Centerville.

Basin characteristics:

$\begin{array}{lrl}\text { Drainage area } & 11.2 \mathrm{mi}^{2} \\ \text { Length } & 5.9 \mathrm{mi} \\ \text { Slope } & 10.9 \mathrm{ft} / \mathrm{mi} \\ \text { Elevation } & 60 & \mathrm{ft} \\ \text { Storage } & 0.45 \mathrm{percent}\end{array}$

$\begin{array}{lrl}\text { Forest } & 25 & \text { percent } \\ \text { Precipitation } & 44.0 & \text { in. } \\ \text { A Soil } & 0 & \text { percent } \\ \text { D Soil } & 15 & \text { percent }\end{array}$

Low-flow characteristics:

$$
\begin{gathered}
\begin{array}{c}
\text { Discharge } \\
\left(\mathrm{ft}^{3} / \mathrm{s}\right)
\end{array} \\
\begin{array}{c}
7-\text { day } \\
14-\text { day } \\
30-\text { day }
\end{array}
\end{gathered}
$$

2-year
4.0
4.3

Recurrence interval

4. 3

2.6

2.8

Basis of low-flow estimates:

Correlated with 01493000, Unicorn Branch near Millington, Md.

Number of base-flow observations used -- 34

Base-flow observations used, made in 1952-53, 1964-71

Equivalent years of record -- 17

Coefficient of determination $\left(\mathrm{R}^{2}\right)-0.95$

Standard error of estimate (SE) -- 16 percent

Minimum observed discharge used in correlation -- $1.70 \mathrm{ft}^{3} / \mathrm{s}$ 
Table 12,--Basin characteristics and low-flow characteristics at partial-record streamflow-gaging stations in Maryland and Delaware--Continued

01494500 Jacobs Creek near Sassafras, Md.

Location: Lat $39^{\circ} 21^{\prime} 50^{\prime \prime}$, long $75^{\circ} 49^{\prime} 13^{\prime \prime}$, Kent County, at bridge on State Highway 290 , 1.2 mi southwest of Sassafras.

Basin characteristics:

Drainage area

Length

Slope

Elevation

Storage

$\begin{array}{ll}5.39 \mathrm{mi}^{2} \\ 3.6 \mathrm{mi} \\ 14.8 \mathrm{ft} / \mathrm{mi} \\ 60 & \mathrm{ft} \\ 0.02 & \text { percent }\end{array}$

$5.39 \mathrm{mi}^{2}$

$14.8 \mathrm{ft} / \mathrm{m}$

0.02 percent

$\begin{array}{lcl}\text { Forest } & 18 & \text { percent } \\ \text { Precipitation } & 46.0 & \text { in. } \\ \text { A Soil } & 0 & \text { percent } \\ \text { D Soil } & 18 & \text { percent }\end{array}$

Precipit

D Soil

Low-flow characteristics:

$$
\frac{\begin{array}{c}
\text { Discharge } \\
\text { (ft } 3 / \mathrm{s})
\end{array}}{\begin{array}{c}
7-\text { day } \\
14-\text { day } \\
30-\text { day }
\end{array}}
$$

\section{Basis of low-flow estimates:}

Correlated with 01493500 , Morgan Creek near Kennedyville, Md.

Number of base-flow observations used -- 23 (daily-flow values)

Base-flow observations used, made in 1951-56 (continuous-record station)

Equivalent years of record -- 12

Coefficient of determination $\left(R^{2}\right)--0.81$

Standard error of estimate (SE) - 18 percent

Minimum observed discharge used in correlation -- $1.5 \mathrm{ft}^{3} / \mathrm{s}$

\section{Mill Creek at Hanesville, Md.}

Location: Lat $39^{\circ} 17^{\prime} 00^{\prime \prime}$, long $76^{\circ} 08^{\prime} 06^{\prime \prime}$, Kent County, at bridge on St. James-Smithville Road, $0.5 \mathrm{mi}$ north of Hanesville.

Basin characteristics:

Drainage area
Length
Slope
Elevation
Storage

\begin{tabular}{|c|c|c|}
\hline 2-year & 10 -year & 20 -year \\
\hline $\begin{array}{l}0.9 \\
1.0 \\
1.2\end{array}$ & $\begin{array}{l}0.4 \\
0.4 \\
0.5\end{array}$ & $\begin{array}{l}0.3 \\
0.3 \\
0.4\end{array}$ \\
\hline
\end{tabular}

$\begin{array}{ll}4.63 \mathrm{mi}^{2} \text { (Revised) } \\ 3.2 \mathrm{mi} \\ 18.6 \mathrm{ft} / \mathrm{mi} \\ 71 & \mathrm{ft} \\ 0.0 & \text { percent }\end{array}$

$\begin{array}{lcl}\text { Forest } & 0 & \text { percent } \\ \text { Precipitation } & 44.5 & \text { in. } \\ \text { A Soil } & 0 & \text { percent } \\ \text { D Soil } & 15 & \text { percent }\end{array}$

Low-flow characteristics:

$$
\begin{gathered}
\begin{array}{c}
\text { Discharge } \\
\left(\mathrm{ft}^{3} / \mathrm{s}\right)
\end{array} \\
\begin{array}{c}
7-\text { day } \\
14-\text { day } \\
30-\text { day }
\end{array}
\end{gathered}
$$

Basis of low-flow estimates:

Correlated with 01493500, Morgan Creek near Kennedyville, Md.

Number of base-flow observations used -- 17

Base-flow observations used, made in 1952-53, 1969-70

Equivalent years of record -- ${ }^{2}{ }^{14}-0.96$

Standard error of estimate (SE) - 17 percent

Minimum observed discharge used in correlation -- $0.67 \mathrm{ft}^{3} / \mathrm{s}$ 
Table 12.--Basin characteristics and low-flow characteristics at partial-record streamflow-gaging stations in Maryland and Delaware--Continued

01495500 Little Elk Creek at Childs, Md.

Location: Lat $39^{\circ} 38^{\prime} 30^{\prime \prime}$, long $75^{\circ} 52^{\prime} 00^{\prime \prime}$, Cecil County, on right bank at highway bridge, 0.2 mi southeast of Childs.

Basin characteristics:

$\begin{array}{lrl}\text { Drainage area } & 26.8 \mathrm{mi}^{2} \\ \text { Length } & 16.1 \mathrm{mi} \\ \text { Slope } & 23.7 \mathrm{ft} / \mathrm{mi} \\ \text { Elevation } & 359 \mathrm{ft} \\ \text { Storage } & 0.06 \mathrm{percent}\end{array}$

$\begin{array}{lcl}\text { Forest } & 23 & \text { percent } \\ \text { Precipitation } & 44.5 & \text { in. } \\ \text { A Soil } & 0 & \text { percent } \\ \text { D Soil } & 7 & \text { percent }\end{array}$

Low-flow characteristics:

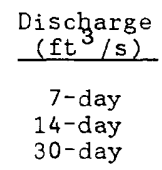

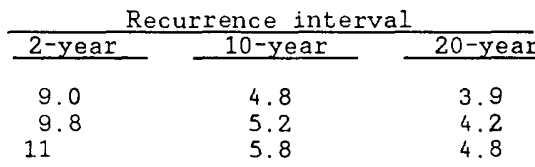

Basis of low-flow estimates:

Correlated with 01495000, Big Elk Creek at Elk Mills, Md.

Number of base-flow observations used - 27 (daily-flow values)

Base-flow observations used, made in 1949-58 (continuous-record station)

Equivalent years of record --
Coefficient of determination $\left(\mathrm{R}^{2}\right)-0.93$

Standard error of estimate (SE) - 16 percent

Minimum observed discharge used in correlation -- $4.2 \mathrm{ft}^{3} / \mathrm{s}$

01495800 Long Creek near Chesapeake City, Md.

Location: Lat $39^{\circ} 33^{\prime} 15^{\prime \prime}$, long $75^{\circ} 47^{\prime} 18^{\prime \prime}$, Cecil County, 10 ft downstream from culvert on farm road, 2.0 mi northeast of Chesapeake City.

Basin characteristics:

$\begin{array}{lcl}\text { Drainage area } & 4.36 \mathrm{mi}^{2} \\ \text { Length } & 3.9 \mathrm{mi} \\ \text { Slope } & 16.2 \mathrm{ft} / \mathrm{mi} \\ \text { Elevation } & 62 & \mathrm{ft} \\ \text { Storage } & 4.28 \text { percent }\end{array}$

$\begin{array}{lcl}\text { Forest } & 42 & \text { percent } \\ \text { Precipitation } & 46.0 & \text { in. } \\ \text { A Soil } & 0 & \text { percent } \\ \text { D Soil } & 52 & \text { percent }\end{array}$

Low-flow characteristics:

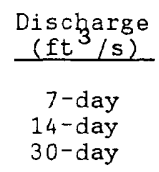

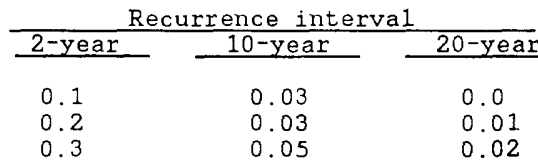

Basis of low-flow estimates:

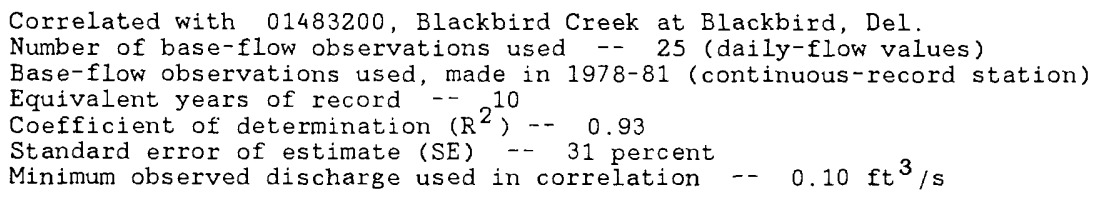


Table 12.--Basin characteristics and low-flow characteristics at partial-record streamflow-gaging stations in Maryland and Delaware--Continued

01495935 Little Bohemia Creek near Warwick, Md.

Location: Lat $39^{\circ} 26^{\prime} 05^{\prime \prime}$, long $75^{\circ} 48^{\prime} 25^{\prime \prime}$, Cecil County, at bridge on county road, 2 mi northwest of Warwick.

Basin characteristics:

$\begin{array}{lclrr}\text { Drainage area } & 2.45 \mathrm{mi}^{2} & \text { Forest } & 8 \text { percent } \\ \text { Length } & 2.6 \mathrm{mi} & \text { Precipitation } & 44.0 \text { in. } \\ \text { Slope } & 29.6 \mathrm{ft} / \mathrm{mi} & \text { A Soil } & 0 & \text { percent } \\ \text { Elevation } & 65 & \mathrm{ft} & \text { D Soil } & 13 \text { percent } \\ \text { Storage } & 0.0 \text { percent } & & \end{array}$

Low-flow characteristics:

$$
\begin{gathered}
\begin{array}{c}
\text { Discharge } \\
\left(\mathrm{ft}^{3} / \mathrm{s}\right)
\end{array} \\
\begin{array}{c}
7-\mathrm{day} \\
14-\mathrm{day} \\
30-\text { day }
\end{array}
\end{gathered}
$$

\begin{tabular}{|c|c|c|}
\hline 2-year & 10 -year & 20 -year \\
\hline 1.4 & 0.8 & 0.7 \\
\hline 1.4 & 0.9 & 0.7 \\
\hline 1.6 & 0.9 & 0.8 \\
\hline
\end{tabular}

\section{Basis of low-flow estimates:}

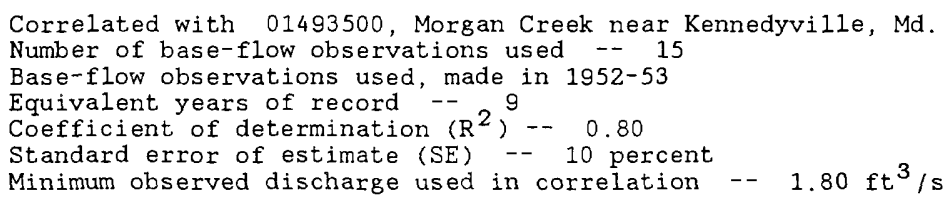

\section{I.ittle Northeast Creek at Mechanic Valley, Md.}

Location: Lat $39^{\circ} 38^{\prime} 26^{\prime \prime}$, long $75^{\circ} 55^{\prime} 49^{\prime \prime}$, Cecil County, at highway bridge on Quarry Road, $0.8 \mathrm{mi}$ northwest of Mechanic Valley.

Basin characteristics:

\begin{tabular}{|c|c|c|}
\hline 2-year & 10-year & 20-year \\
\hline 3.0 & 1.4 & 1.0 \\
\hline 3.3 & 1.5 & 1.2 \\
\hline 3.7 & 1.7 & 1.4 \\
\hline
\end{tabular}

$\begin{array}{lrlll}\text { Drainage area } & 14.2 \mathrm{mi}^{2} & \text { Forest } & 26 \text { percent } \\ \text { Length } & 9.2 \mathrm{mi} & \text { Precipitation } & 44.0 \mathrm{in} . \\ \text { Slope } & 27.9 \mathrm{ft} / \mathrm{mi} & \text { A Soil } & \text { ND } \\ \text { Elevation } & 362 & \mathrm{ft} & \text { D Soil } & \text { ND } \\ \text { Storage } & 0.24 \text { percent } & & \end{array}$

Low-flow characteristics:

$$
\frac{\begin{array}{c}
\text { Discharge } \\
\left(\mathrm{ft}^{3} / \mathrm{s}\right)
\end{array}}{\begin{array}{c}
7-\text { day } \\
14-\text { day } \\
30-\text { day }
\end{array}}
$$

Basis of low-flow estimates:

Correlated with 01496000 , Northeast Creek at Les1ie, Md.

Number of base-flow observations used -- 14

Base-flow observations used, made in 1964-74

Equivalent years of record -- 18

Coefficient of determination $\left(\mathrm{R}^{2}\right)--0.96$

Standard error of estimate (SE) -- 18 percent

Minimum observed discharge used in correlation -- $1.03 \mathrm{ft}^{3} / \mathrm{s}$ 
Table 12.--Basin characteristics and low-flow characteristics at partial-record streamflow-gaging stations in Maryland and Delaware--Continued

\section{Broad Creek at Pylesville, Md.}

Location: Lat $39^{\circ} 41^{\prime} 16^{\prime \prime}$, long $76^{\circ} 22^{\prime} 24^{\prime \prime}$, Harford County, 400 ft below bridge on old State Highway 165, at Pylesvilie.

Basin characteristics:

$\begin{array}{lrl}\text { Drainage area } & 11.3 \mathrm{mi}^{2} \\ \text { Length } & 4.4 \mathrm{mi} \\ \text { Slope } & 67.0 \mathrm{ft} / \mathrm{mi} \\ \text { Elevation } & 483 & \mathrm{ft} \\ \text { Storage } & 0.04 \text { percent }\end{array}$

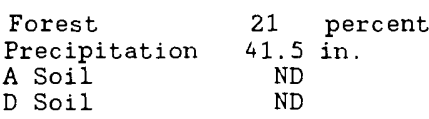

Low-flow characteristics:

$\frac{\begin{array}{l}\text { Discharge } \\ \left(\mathrm{ft}^{3} / \mathrm{s}\right)\end{array}}{\begin{array}{c}7-\text { day } \\ 14-\text { day } \\ 30-\text { day }\end{array}}$

\begin{tabular}{|c|c|c|}
\hline 2-year & 10 -year & 20 -year \\
\hline 3.7 & 1.5 & 1.1 \\
\hline 4.0 & 1.6 & 1.2 \\
\hline 4.4 & 1.9 & 1.4 \\
\hline
\end{tabular}

Basis of low-flow estimates:

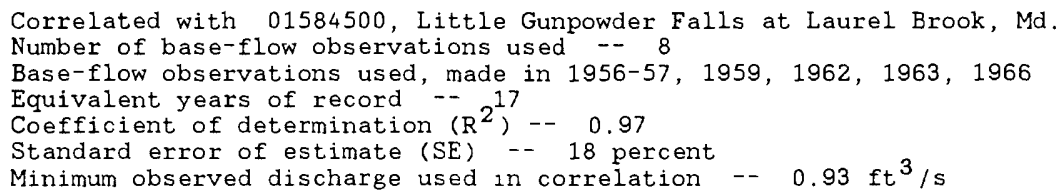

01579000 Basin Run at Liberty Grove, Md.

Location: Lat $39^{\circ} 39^{\prime} 30^{\prime \prime}$, long $76^{\circ} 06^{\prime} 10^{\prime \prime}$, Cecil County, 100 ft upstream from bridge on Lipencott Road, $0.9 \mathrm{mi}$ east of Liberty Grove.

Basin characteristics:

Drainage area
Length
Slope
Elevation
Storage

$\begin{array}{cl}5.31 & \mathrm{mi}^{2} \\ 3.7 & \mathrm{mi} \\ 37.0 & \mathrm{ft} / \mathrm{mi} \\ 348 & \mathrm{ft} \\ 0.08 & \text { percent }\end{array}$

$\begin{array}{lcl}\text { Forest } & 22 & \text { percent } \\ \text { Precipitation } & 42.5 & \text { in. } \\ \text { A Soil } & 0 & \text { percent } \\ \text { D Soil } & 3 & \text { percent }\end{array}$

Low-flow characteristics:

$$
\begin{gathered}
\begin{array}{c}
\text { Discharge } \\
\left(\mathrm{ft}^{3} / \mathrm{s}\right)
\end{array} \\
\begin{array}{c}
7-\text { day } \\
14-\text { day } \\
30-\text { day }
\end{array}
\end{gathered}
$$

\begin{tabular}{|c|c|c|}
\hline 2-year & 10-year & 20 -year \\
\hline $\begin{array}{l}1.6 \\
1.8 \\
2.0\end{array}$ & $\begin{array}{l}0.8 \\
0.9 \\
1.0\end{array}$ & $\begin{array}{l}0.7 \\
0.7 \\
0.8\end{array}$ \\
\hline
\end{tabular}

\section{Basis of low-flow estimates:}

Correlated with 01495000 , Big Elk Creek at Elk Mills, Md.

Number of base-flow observations used - 27 (daily-flow values)

Base-flow observations used, made in 1949-58 (continuous-record station)

Equivalent years of record -
Coefficient of determination $\left(\mathrm{R}^{2}\right)--0.95$

Standard error of estimate (SE) - 17 percent

Minimum observed discharge used in correlation -- $0.60 \mathrm{ft}^{3} / \mathrm{s}$ 
Table 12.--Basin characteristics and low-flow characteristics at partial-record streamflow-gaging stations in Maryland and Delaware--Continued

01579875 Dear Creek at Gorsuch Mi11s, Md.

Location: Lat $39^{\circ} 42^{\prime} 21^{\prime \prime}$, long $76^{\circ} 35^{\prime} 15^{\prime \prime}$, Baltimore County, at bridge on West Liberty Road, 0.1 mi south of Gorsuch Mills.

Basin characteristics:

$\begin{array}{lrllc}\text { Drainage area } & 25.4 \mathrm{mi}^{2} & \text { Forest } & 30 \text { percent } \\ \text { Length } & 9.3 \mathrm{mi} & \text { Precipitation } & 44.0 \text { in. } \\ \text { Slope } & 39.2 \mathrm{ft} / \mathrm{mi} & \text { A Soil } & \text { ND } \\ \text { Elevation } & 805 & \mathrm{ft} & \text { D Soil } & \text { ND } \\ \text { Storage } & 0.12 \text { percent } & & \end{array}$

\section{Low-flow characteristics:}

Discharge
$\left(\mathrm{ft}^{3} / \mathrm{s}\right)$
7 -day
$14-$ day
$30-$ day

\begin{tabular}{|c|c|c|}
\hline 2-year & 10-year & 20 -year \\
\hline $\begin{array}{l}12 \\
12 \\
13\end{array}$ & $\begin{array}{l}5.9 \\
6.3 \\
7.2\end{array}$ & $\begin{array}{l}4.6 \\
5.0 \\
5.9\end{array}$ \\
\hline
\end{tabular}

Basis of low-flow estimates:

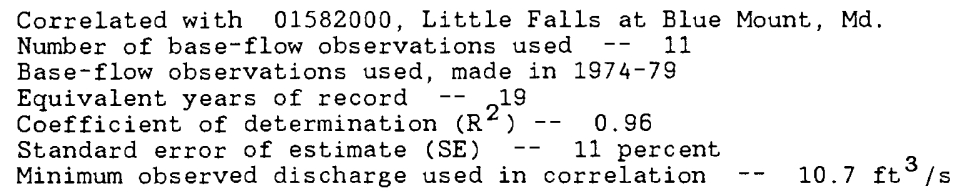

01579900 Big Branch at Harkins, Md.

Location (Revised): Lat $39^{\circ} 41^{\prime} 53^{\prime \prime}$, long $76^{\circ} 27^{\prime} 59^{\prime \prime}$, Harford County, at bridge on State Highway $136,0.8$ mi west of Harkins.

Basin characteristics:

Drainage area
Length
Slope
Elevation
Storage

$6.39 \mathrm{mi}^{2}$
$4.3 \mathrm{mi}$
$66.3 \mathrm{ft} / \mathrm{mi}$
$671 \mathrm{ft}$
0.14 percent

$\begin{array}{lrl}\text { Forest } & 21 & \text { percent } \\ \text { Precipitation } & 44.0 \text { in. } \\ \text { A Soil } & \text { ND } \\ \text { D Soil } & \text { ND }\end{array}$

Low-flow characteristics:

$$
\begin{gathered}
\begin{array}{c}
\text { Discharge } \\
\left(\mathrm{ft}^{3} / \mathrm{s}\right)
\end{array} \\
\begin{array}{l}
7-\text { day } \\
\text { 14-day } \\
30-\text { day }
\end{array}
\end{gathered}
$$

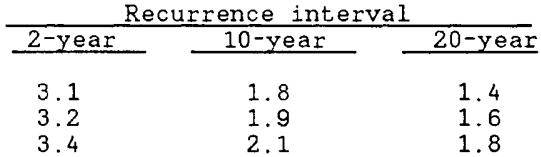

Basis of low-flow estimates:

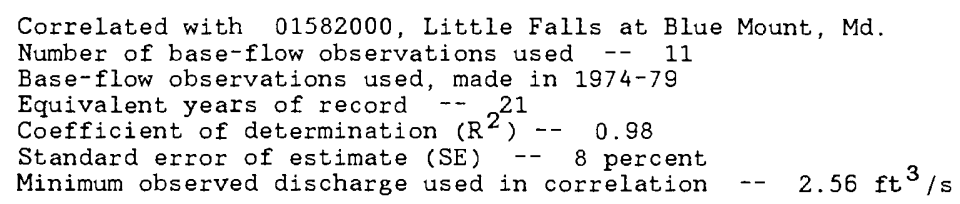


Table 12.--Basin characteristics and low-flow characteristics at partial-record streamflow-gaging stations in Maryland and Delaware--Continued

01579925 Little Deer Creek near Federal Hill, Md.

Location: Lat $39^{\circ} 39^{\prime} 42^{\prime \prime}$, long $76^{\circ} 26^{\prime} 55^{\prime \prime}$, Harford County, at bridge on State Highway 165 , 1.9 mi northeast of Federal Hill.

Basin characteristics:

$\begin{array}{lrl}\text { Drainage area } & 14.0 \mathrm{mi} \\ \text { Length } & 8.3 \mathrm{mi} \\ \text { Slope } & 32.1 \mathrm{ft} / \mathrm{mi} \\ \text { Elevation } & 515 & \mathrm{ft} \\ \text { Storage } & 0.28 \text { percent }\end{array}$

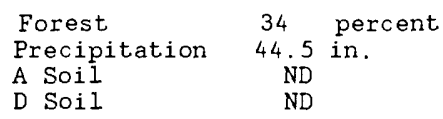

Low-flow characteristics:

$\begin{gathered}\text { Discharge } \\ \left(\mathrm{ft}^{3} / \mathrm{s}\right)\end{gathered}$
$\begin{gathered}7-\text { day } \\ 14-\text { day } \\ 30-\text { day }\end{gathered}$

\begin{tabular}{lccc}
\multicolumn{3}{c}{ Recurrence interval } \\
\cline { 1 - 1 } 2-year & 10-year & 20-year \\
6.1 & 3.4 & \\
6.4 & 3.6 & 2.7 \\
6.8 & 4.0 & 2.9 \\
& & 3.4
\end{tabular}

Basis of low-flow estimates:

Correlated with 01582000, Little Falls at Blue Mount, Md.

Number of base-flow observations used -- 12

Base-flow observations used, made in 1974-79

Equivalent years of record -- 21

Coefficient of determination $\left(\mathrm{R}^{2}\right)-0.97$

Standard error of estimate (SE) - 9 percent

Minimum observed discharge used in correlation -- $5.34 \mathrm{ft}^{3} / \mathrm{s}$

01580170 Stout Bott.le Branch near Ady, Md.

Location: Lat $39^{\circ} 37^{\prime} 14^{\prime \prime}$, long $76^{\circ} 20^{\prime} 01^{\prime \prime}$, Harford County, at bridge on Walters Mill Road, $1.4 \mathrm{mi}$ southwest of Ady.

Basin characteristics:

Drainage area
Length
Slope
Elevation
Storage

$\begin{array}{ll}7.13 \mathrm{mi}^{2} \\ 4.0 \mathrm{mi} \\ 51.7 \mathrm{ft} / \mathrm{mi} \\ 383 & \mathrm{ft} \\ 0.28 & \text { percent }\end{array}$

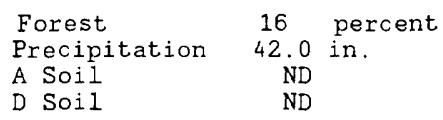

Low-flow characteristics:

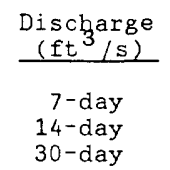

Recurrence interval

$14-$ day
$30-$ day

3.5
3.7
3.9

1.9
2.0

20-year

Basis of low-flow estimates:

Correlated with 01582000, Little Falls at Blue Mount, Md.

Number of base-flow observations used - 8

Base-flow observations used, made in 1980-82

Equivalent years of record - 21

Coefficient of determination $\left(R^{2}\right)--0.99$

Standard error of estimate (SE) -- 6 percent

Minimum observed discharge used in correlation -- $2.30 \mathrm{ft}^{3} / \mathrm{s}$ 
Table 12.--Basin characteristics and low-flow characteristics at partial-record streamflow-gaging stations in Maryland and Delaware--Continued

\section{Bynum Run at Bush, Md.}

Location: Lat $39^{\circ} 28^{\prime} 19^{\prime \prime}$, long $76^{\circ} 16^{\prime} 01^{\prime \prime}$, Harford County, at bridge on State Highway 7 , 0.2 mi southwest of Bush.

\section{Basin characteristics:}

$\begin{array}{lcl}\text { Drainage area } & 22.5 \mathrm{mi}^{2} \\ \text { Length } & 13.9 \mathrm{mi} \\ \text { Slope } & 36.4 \mathrm{ft} / \mathrm{mi} \\ \text { Elevation } & 295 \mathrm{ft} \\ \text { Storage } & 0.12 \mathrm{percent}\end{array}$

$\begin{array}{lr}\text { Forest } & 39 \text { percent } \\ \text { Precipitation } & 43.0 \text { in. } \\ \text { A Soil } & \text { ND } \\ \text { D Soil } & \text { ND }\end{array}$

Low-flow characteristics:

$$
\begin{aligned}
& \begin{array}{c}
\text { Discharge } \\
\text { (ft } 3 / \mathrm{s})
\end{array} \\
& \text { 7-day } \\
& \text { 14-day } \\
& \begin{array}{l}
\text { 14-day } \\
\text { 30-day }
\end{array}
\end{aligned}
$$

Basis of low-flow estimates:

Correlated with 01581500 , Bynum Run at Bel Air, Md.

Number of base-flow observations used -- 10

Base-flow observations used, made in 1956-59, 1962-63, 1966

Equivalent years of record -- 9

Coefficient of determination $\left(R^{2}\right)--0.96$

Standard error of estimate (SE) -- 16 percent

Minimum observed discharge used in correlation - $2.77 \mathrm{ft}^{3} / \mathrm{s}$

01581650 James Rum at Bush, Md.

Location: Lat $39^{\circ} 28^{\prime} 35^{\prime \prime}$, long $76^{\circ} 15^{\prime} 38^{\prime \prime}$, Harford County, at bridge on State Highway 7 , 0.2 mi northeast of Bush.

Basin characteristics:

Drainage area
Length
Slope
Elevation
Storage

$\begin{array}{rl}11.1 & \mathrm{mi}^{2} \\ 6.7 & \mathrm{mi} \\ 62.9 & \mathrm{ft} / \mathrm{mi} \\ 287 & \mathrm{ft} \\ 0.07 & \text { percent }\end{array}$

$\begin{array}{lc}\text { Forest } & 38 \text { percent } \\ \text { Precipitation } & 43.0 \text { in. } \\ \text { A Soil } & \text { ND } \\ \text { D Soil } & \text { ND }\end{array}$

Low-flow characteristics:

$$
\frac{\begin{array}{c}
\text { Discharge } \\
\text { (ft } 3 / \mathrm{s})
\end{array}}{\begin{array}{c}
7-\text { day } \\
14-\text { day } \\
30-\text { day }
\end{array}}
$$

Basis of low-flow estimates:

\begin{tabular}{ccc}
\multicolumn{3}{c}{ Recurrence interval } \\
$\frac{10 \text {-year }}{1.1}$ & 0.1 & 20-year \\
1.2 & 0.2 & 0.1 \\
1.6 & 0.5 & 0.1 \\
& & 0.4
\end{tabular}

\footnotetext{
Correlated with 01581500, Bynum Run at Bel Air, Md.

Number of base-flow observations used -- 10

Base-flow observations used, made in 1956-59, 1952-53, 1965

Equivalent years of record -- $2^{9}$

Coefficient of determination $\left(R^{2}\right)-0.98$

Standard error of estimate (SE) - 16 percent

Minimum observed discharge used in correlation -- $0.41 \mathrm{ft}^{3} / \mathrm{s}$
} 
Table 12.--Basin characteristics and low-flow characteristics at partial-record streamflow-gaging stations in Maryland and Delaware--Continued

\section{Georges Rum at Armacost, Md.}

Location: Lat $39^{\circ} 36^{\prime} 55^{\prime \prime}$, long $76^{\circ} 47^{\prime} 26^{\prime \prime}$, Baltimore County, at bridge on State Highway 25 , 0.7 mi northeast of Armacost.

Basin characteristics:

Drainage area

Length

Slope

Elevation

Storage

$\begin{array}{rl}13.0 & \mathrm{mi}^{2} \\ 7.0 & \mathrm{mi} \\ 50.0 & \mathrm{ft} / \mathrm{mi} \\ 774 & \mathrm{ft} \\ 0.0 & \text { percent }\end{array}$

Low-flow characteristics:

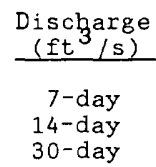

Basis of low-flow estimates:

$\begin{array}{lrr}\text { Forest } & 21 & \text { percent } \\ \text { Precipitation } & 44.5 \text { in. } \\ \text { A Soil } & \text { ND } \\ \text { D Soil } & \text { ND }\end{array}$

A Soil

\footnotetext{
Correlated with 01582000, Little Falls at Blue Mount, Md.

Number of base-flow observations used -- 9

Base-flow observations used, made in 1956-59, 1962, 1966

Equivalent years of record -- 21

Coefficient of determination $\left(\mathrm{R}^{2}\right)--0.99$

Standard error of estimate (SE) - 8 percent

Minimum observed discharge used in correlation -- $1.12 \mathrm{ft}^{3} / \mathrm{s}$
}

01581960 Beetree Run at Bentley Springs, Md.

Location: Lat $39^{\circ} 40^{\prime} 23^{\prime \prime}$, long $76^{\circ} 40^{\prime} 31^{\prime \prime}$, Baltimore County, at bridge on Bentley Road in Bentley Springs.

Basin characteristics

Drainage area
Length
Slope
Elevation
Storage

$\begin{array}{ll}9.72 & \mathrm{mi}^{2} \\ 6.5 & \mathrm{mi} \\ 63.0 \mathrm{ft} / \mathrm{mi} \\ 775 & \mathrm{ft} \\ 0.21 & \text { percent }\end{array}$

$\begin{array}{lrl}\text { Forest } & 37 & \text { percent } \\ \text { Precipitation } & 44.5 & \text { in. } \\ \text { A Soil } & \text { ND } & \\ \text { D Soil } & \text { ND }\end{array}$

Low-flow characteristics

$$
\begin{gathered}
\text { Discharge } \\
\frac{\left(\mathrm{ft}^{3} / \mathrm{s}\right)}{\text { 7-day }} \\
\begin{array}{l}
\text { 14-day } \\
\text { 30-day }
\end{array}
\end{gathered}
$$

\begin{tabular}{|c|c|c|}
\hline 2-year & 10 -year & 20-year \\
\hline $\begin{array}{l}5.0 \\
5.2 \\
5.5\end{array}$ & $\begin{array}{l}2.7 \\
2.8 \\
3.2\end{array}$ & $\begin{array}{l}2.2 \\
2.3 \\
2.7\end{array}$ \\
\hline
\end{tabular}

Basis of low-flow estimates:

Correlated with 01582000 , Little Falls at Blue Mount, Md.

Number of base-flow observations used -- 11

Base-flow observations used, made in 1974-79

Equivalent years of record --
Coefficient of determination $\left(R^{2}\right)--0.97$

Standard exror of estimate (SE) - 9 percent

Minimum observed discharge used in correlation -- $4.38 \mathrm{ft}^{3} / \mathrm{s}$ 
Table 12.--Basin characteristics and low-flow characteristics at partial-record streamflow-gaging stations in Maryland and Delaware--Continued

01581980 Third Mine Branch near Stablersville, Md.

Location: Lat $39^{\circ} 39^{\prime} 27^{\prime \prime}$, long $76^{\circ} 37^{\prime} 24^{\prime \prime}$. Baltimore County, at bridge on Ensor Road, 0.6 mi northwest of Stablersvilie.

Basin characteristics:

Drainage area
Length
Slope
Elevation
Storage

$\begin{array}{rl}5.27 \mathrm{mi}^{2} \\ 3.2 \mathrm{mi} \\ 74.6 \mathrm{ft} / \mathrm{mi} \\ 674 & \mathrm{ft} \\ 0.09 & \text { percent }\end{array}$

Forest Precipitation

A Soil

61 percent

Storage

0.09 percent

D Soil

4.5 in

ND

ND

Low-flow characteristics:

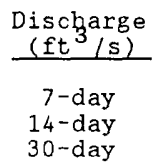

\begin{tabular}{ccc}
\multicolumn{3}{c}{ Recurrence interva1 } \\
\cline { 1 - 1 } 2-year & 10-year & 20-year \\
2.0 & 1.0 & 0.8 \\
2.2 & 1.1 & 0.8 \\
2.3 & 1.2 & 1.0
\end{tabular}

Basis of low-flow estimates:

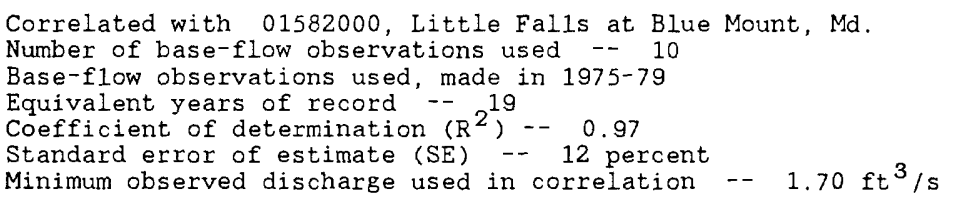

01582900 Greene Branch at Phoenix, Md.

Location: Lat $39^{\circ} 30^{\prime} 22^{\prime \prime}$, long $76^{\circ} 36^{\prime} 50^{\prime \prime}$, Baltimore County, at bridge on Phoenix Road, 0.6 mi northwest of Phoenix.

Basin characteristics:

Drainage area
Length
Slope
Elevation
Storage

$\begin{array}{rl}4.45 & \mathrm{mi}^{2} \\ 3.0 & \mathrm{mi} \\ 87.8 & \mathrm{ft} / \mathrm{mi} \\ 510 & \mathrm{ft} \\ 0.19 & \text { percent }\end{array}$

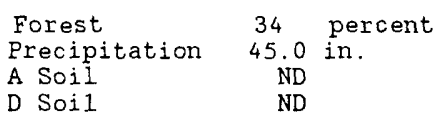

Low-flow characteristics:

$$
\frac{\begin{array}{c}
\text { Discharge } \\
\text { (ft } \left.{ }^{3} / \mathrm{s}\right)
\end{array}}{\text { 7-day }}
$$

\begin{tabular}{ccc}
\multicolumn{3}{c}{ Recurrence interval } \\
2-year & 10-year & 20-year \\
1.8 & 0.8 & 0.6 \\
1.9 & 0.8 & 0.6 \\
2.0 & 1.0 & 0.8
\end{tabular}

Basis of low-flow estimates:

Correlated with 01583500, Western Run at Western Run, Md.

Number of base-flow observations used -- 14

Base-flow observations used, made in 1973-79

Equivalent years of record - 19

Coefficient of determination $\left(R^{2}\right) \cdots 0.94$

Standard error of estimate (SE) -- 15 percent

Minimum observed discharge used in correlation -- $1.22 \mathrm{ft}^{3} / \mathrm{s}$ 
Table 12.--Basin characteristics and low-flow characteristics at partial-record streamflow-gaging stations in Maryland and Delaware--Continued

01583100 Piney Run at Dover, Md.

Location: Lat $39^{\circ} 31^{\prime} 17^{\prime \prime}$, long $76^{\circ} 46^{\prime} 00^{\prime \prime}$, Baltimore County, at bridge on State Highway 128 , 0.7 mi north of Dover.

Basin characteristics:

$\begin{array}{lrllr}\text { Drainage area } & 12.3 \mathrm{mi}^{2} & \text { Forest } & 28 \text { percent } \\ \text { Length } & 8.4 \mathrm{mi} & \text { Precipitation } & 44.5 \mathrm{in} . \\ \text { Slope } & 46.9 \mathrm{ft} / \mathrm{mi} & \text { A Soil } & \text { ND } \\ \text { Elevation } & 652 & \text { D Soil } & \text { ND } \\ \text { Storage } & 0.19 \text { percent } & & \end{array}$

Low-flow characteristics:

Discharge
$\frac{\left(\mathrm{ft}^{3} / \mathrm{s}\right)}{7-\text { day }}$
$\begin{aligned} & \text { 14-day } \\ & \text { 30-day }\end{aligned}$

\begin{tabular}{|c|c|c|}
\hline 2-year & 10 -year & 20 -year \\
\hline $\begin{array}{l}5.6 \\
5.8 \\
6.2\end{array}$ & $\begin{array}{l}2.8 \\
3.0 \\
3.4\end{array}$ & $\begin{array}{l}2.2 \\
2.4 \\
2.8\end{array}$ \\
\hline
\end{tabular}

\section{Basis of low-flow estimates:}

Correlated with 01583500, Western Run at Western Run, Md.

Number of base-flow observations used -- 10 (discharge measurements)

Base-flow observations used, made in 1975-79 (partial-record station)

Equivalent years of record -- 21

1982-87 (continuous-record station)

Coefficient of determination $\left(\mathrm{R}^{2}\right) \ldots 0.97$

Standard error of estimate (SE) - 11 percent

Minimum observed discharge used in correlation -- $2.6 \mathrm{ft}^{3} / \mathrm{s}$

01583200 Blackrock Run at Coopersville, Md.

Location (Revised). Lat $39^{\circ} 32^{\prime} 36^{\prime \prime}$, long $76^{\circ} 44^{\prime} 00^{\prime \prime}$, Baltimore County, at bridge on Stringtown Road, 0.5 mi southeast of Coopersville.

Basin characteristics:

Drainage area
Length
Slope
Elevation
Storage

$\begin{array}{rl}9.38 \mathrm{mi}^{2} \\ 6.9 \mathrm{mi} \\ 50.5 \mathrm{ft} / \mathrm{mi} \\ 624 & \mathrm{ft} \\ 0.05 & \text { percent }\end{array}$

Forest 34 percent Precipitation 45.0 in.

A Soil ND

Storage

D Soil

ND

Low-flow characteristics:

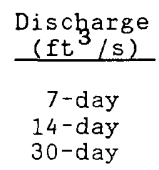

\begin{tabular}{|c|c|c|}
\hline 2-year & 10 -year & 20-year \\
\hline 4.3 & 1.7 & 1.2 \\
\hline 4.6 & 1.8 & 1.3 \\
\hline 4.9 & 2.1 & 1.6 \\
\hline
\end{tabular}

Basis of low-flow estimates:

Correlated with 01583500, Western Run at Western Run, Md.

Number of base-flow observations used -- 11

Base-flow observations used, made in 1956-59, 1962-63, 1966

Equivalent years of record -- 21

Coefficient of determination $\left(R^{2}\right)-0.94$

Standard error of estimate (SE) - 22 percent

Minimum observed discharge used in correlation -- $1.26 \mathrm{ft}^{3} / \mathrm{s}$ 
Table 12.--Basin characteristics and low-flow characteristics at partial-record streamflow-gaging stations in Maryland and Delaware--Continued

\section{Beaverdam Run at Cockeysville, Md.}

Location: Lat $39^{\circ} 29^{\prime} 08^{\prime \prime}$, long $76^{\circ} 38^{\prime} 45^{\prime \prime}$, Baltimore County, at bridge on State Highway 45 , at Cockeysville.

Basin characteristics:

Drainage area
Length
Slope
Elevation
Storage

$\begin{array}{rl}20.8 & \mathrm{mi}^{2} \\ 4.7 & \mathrm{mi} \\ 76.4 & \mathrm{ft} / \mathrm{mi} \\ 465 & \mathrm{ft} \\ 0.28 & \text { percent }\end{array}$

$\begin{array}{lr}\text { Forest } & 38 \text { percent } \\ \text { Precipitation } & 45.0 \text { in. } \\ \text { A Soil } & \text { ND } \\ \text { D Soil } & \text { ND }\end{array}$

Low-flow characteristics:

$\begin{gathered}\text { Discharge } \\ \left(\mathrm{ft}^{3} / \mathrm{s}\right)\end{gathered}$
$\begin{gathered}7-\text { day } \\ 14-\text { day } \\ 30-\text { day }\end{gathered}$

A Soil

ND

Basis of low-flow estimates:

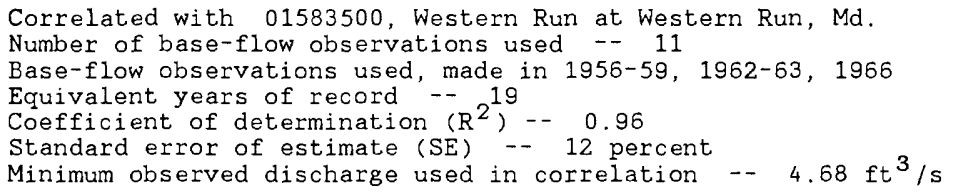

\section{Little Gunpowder Falls at Hess, Md.}

Location: Lat $39^{\circ} 32^{\prime} 37^{\prime \prime}$, long $76^{\circ} 31^{\prime} 53^{\prime \prime}$, Baltimore County, at bridge on State Highway 146 , 0.8 mi south of Hess.

Basin characteristics:

$\begin{array}{lrl}\text { Drainage area } & 16.5 \mathrm{mi}^{2} \\ \text { Length } & 7.1 \mathrm{mi} \\ \text { Slope } & 38.3 \mathrm{ft} / \mathrm{mi} \\ \text { Elevation } & 564 & \mathrm{ft} \\ \text { Storage } & 0.11 \text { percent }\end{array}$

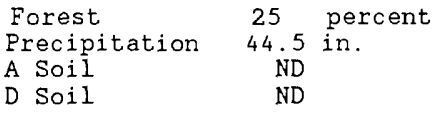

Low-flow characteristics:

$$
\frac{\begin{array}{c}
\text { Discharge } \\
\left(\mathrm{ft}^{3} / \mathrm{s}\right)
\end{array}}{\begin{array}{c}
7-\text { day } \\
14-\text { day } \\
30-\text { day }
\end{array}}
$$

\begin{tabular}{lcc}
\multicolumn{3}{c}{ Recurrence interval } \\
\cline { 1 - 2 } 2-year & 10-year & 20-year \\
11 & 5.7 & \\
11 & 6.0 & 4.6 \\
12 & 6.6 & 4.9 \\
& & 5.6
\end{tabular}


Table 12.--Basin characteristics and low-flow characteristics at partial-record streamflow-gaging stations in Maryland and Delaware--Continued

01585500 Cranberry Branch near Westminster, Md.

Location: Lat $39^{\circ} 35^{\prime} 35^{\prime \prime}$, long $76^{\circ} 58^{\prime} 05^{\prime \prime}$, Carroll County, 80 ft upstream from culvert, 1.8 mi northeast of Westminster.

Basin characteristics:

Drainage area

Length

Slope

Elevation

Storage

$\begin{array}{ll}3.29 \mathrm{mi}^{2} \\ 3.5 & \mathrm{mi} \\ 56.0 & \mathrm{ft} / \mathrm{mi} \\ 823 & \mathrm{ft} \\ 0.0 & \text { percent }\end{array}$

Forest

A Soil

23 percent

D Soil

ND

ND

0.0 percent

Low-flow characteristics:

Discharge
$\left(\mathrm{ft}^{3} / \mathrm{s}\right)$
$\begin{gathered}7-\text { day } \\ 14-\text { day } \\ 30-\text { day }\end{gathered}$

\begin{tabular}{|c|c|c|}
\hline 2-year & 10 -year & 20 -year \\
\hline $\begin{array}{l}1.3 \\
1.3 \\
1.4\end{array}$ & $\begin{array}{l}0.6 \\
0.6 \\
0.7\end{array}$ & $\begin{array}{l}0.5 \\
0.5 \\
0.6\end{array}$ \\
\hline
\end{tabular}

Basis of low-flow estimates:

Correlated with 01583500, Western Run at Western Run, Md.

Number of base-flow observations used - 25 (daily-flow values)

Base-flow observations used, made in 1950-57 (continuous-record station)

Equivalent years of record -- 19

Coefficient of determination $\left(R^{2}\right)-0.96$

Standard error of estimate (SE) - 14 percent

Minimum observed discharge used in correlation -- $0.70 \mathrm{ft}^{3} / \mathrm{s}$

01586210 Beaver Run at Finksburg, Hd.

Location: Lat $39^{\circ} 29^{\prime} 44^{\prime \prime}$, long $76^{\circ} 54^{\prime} 09^{\prime \prime}$, Carroll County, at highway bridge, 0.7 mi northwest of Finksburg.

Basin characteristics:

$\begin{array}{lrl}\text { Drainage area } & 12.7 \mathrm{mi}^{2} \\ \text { Length } & 8.4 \mathrm{mi} \\ \text { Slope } & 41.6 \mathrm{ft} / \mathrm{mi} \\ \text { Elevation } & 735 & \mathrm{ft} \\ \text { Storage } & 0.10 \mathrm{percen}\end{array}$

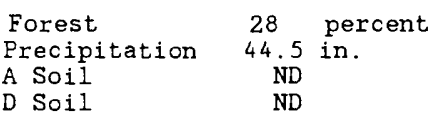

Low-flow characteristics:

$$
\begin{gathered}
\text { Discharge } \\
\text { (ft } \left.\mathrm{ft}^{3} / \mathrm{s}\right) \\
\text { 7-day } \\
\text { 14-day } \\
30-\text { day }
\end{gathered}
$$

\begin{tabular}{ccc}
\multicolumn{3}{c}{ Recurrence interval } \\
\cline { 1 - 1 } 2-year & 10-year & 20-year \\
4.3 & & \\
4.6 & 2.9 & 1.4 \\
4.9 & 2.0 & 1.6 \\
& & 1.9
\end{tabular}

Basis of 10w-flow estimates:

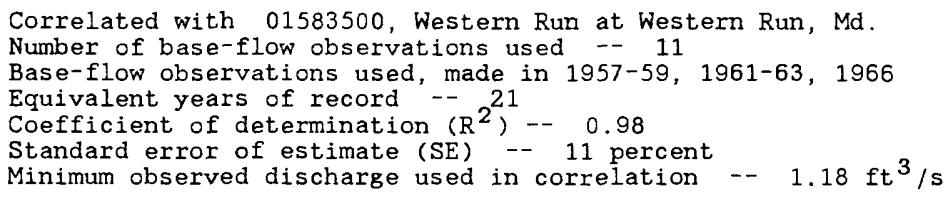


Table 12.--Basin characteristics and low-flow characteristics at partial-record streamflow-gaging stations in Maryland and Delaware--Continued

01586610 Morgan Run near Gamber, Md.

Location: Lat $39^{\circ} 27^{\prime} 58^{\prime \prime}$, long $76^{\circ} 58^{\prime} 16^{\prime \prime}$, Carroll County, at bridge on Klees Mill Road, 1.9 mi west of Gamber.

Basin characteristics:

$\begin{array}{lrl}\text { Drainage area } & 26.0 \mathrm{mi}^{2} \\ \text { Length } & 7.8 \mathrm{mi} \\ \text { Slope } & 34.1 \mathrm{ft} / \mathrm{mi} \\ \text { Elevation } & 737 & \mathrm{ft} \\ \text { Storage } & 0.04 \text { percent }\end{array}$

$\begin{array}{lr}\text { Forest } & 29 \\ \text { Precipitation } & 44.0 \text { in. } \\ \text { A Soil } & \text { ND } \\ \text { D Soil } & \text { ND }\end{array}$

Storage

0.04 percent

Low-flow characteristics:

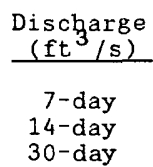

\begin{tabular}{|c|c|c|}
\hline \multirow{2}{*}{\multicolumn{3}{|c|}{$\begin{array}{l}\text { Recurrence interval } \\
\text { r } \\
10 \text {-year }\end{array}$}} \\
\hline & & \\
\hline 8.3 & 3.6 & 2.7 \\
\hline $\begin{array}{l}8.7 \\
9.3\end{array}$ & $\begin{array}{l}3.8 \\
4.4\end{array}$ & $\begin{array}{l}2.9 \\
3.5\end{array}$ \\
\hline
\end{tabular}

Basis of low-flow estimates:

Correlated with 01583500, Western Run at Western Run, Md

Number of base-flow observations used -- 12

Base-flow observations used, made in 1957-59, 1961-63, 1966

Equivalent years of record - 21

Coefficient of determination $\left(R^{2}\right)--0.96$

Standard error of estimate (SE) - 15 percent

Minimum observed discharge used in correlation -- $2.19 \mathrm{ft}^{3} / \mathrm{s}$

01586650 Little Morgan Run near Eldersburg, Md.

Location: Lat $39^{\circ} 25^{\prime} 35^{\prime \prime}$, long $76^{\circ} 57^{\prime} 40^{\prime \prime}$, Carroll County, at bridge on Bartholow Road, 0.7 mi north of Johnsville.

Basin characteristics:

Drainage area
Length
Slope
Elevation
Storage

$7.13 \mathrm{mi}^{2}$
$4.9 \mathrm{mi}$
$68.2 \mathrm{ft} / \mathrm{mi}$
$662 \mathrm{ft}$
0.10 percent

$\begin{array}{lc}\text { Forest } & 28 \text { percent } \\ \text { Precipitation } & 44.0 \text { in. } \\ \text { A Soil } & \text { ND } \\ \text { D Soil } & \text { ND }\end{array}$

Low-flow characteristics:

$$
\begin{aligned}
& \begin{array}{c}
\text { Discharge } \\
\text { (ft } 3 / \mathrm{s})
\end{array} \\
& \text { 7-day } \\
& \text { 14-day } \\
& \text { 30-day }
\end{aligned}
$$

\begin{tabular}{|c|c|c|}
\hline 2-year & 10 -year & 20-year \\
\hline $\begin{array}{l}2.6 \\
2.6 \\
2.7\end{array}$ & $\begin{array}{l}0.8 \\
0.9 \\
1.2\end{array}$ & $\begin{array}{l}0.4 \\
0.6 \\
0.9\end{array}$ \\
\hline
\end{tabular}

Basis of low-flow estimates:

Correlated with 01587500 , South Branch Patapsco River at Henryton, Md.

Number of base-flow observations used -- 11

Base-flow observations used, made in 1973, 1975-79

Equivalent years of record -- 14

Coefficient of determination $\left(R^{2}\right)-0.96$

Standard error of estimate (SE) -- 12 percent

Minimum observed discharge used in correlation -- $1.80 \mathrm{ft}^{3} / \mathrm{s}$ 
Table 12,--Basin characteristics and low-flow characteristics at partial-record streamflow-gaging stations in Maryland and Delaware--Continued

01587170 Gillis Falls at Woodbine, Md.

Location: Lat $39^{\circ} 21^{\prime} 48^{\prime \prime}$, long $77^{\circ} 03^{\prime} 59^{\prime \prime}$, Carroll County, at bridge on dirt road, 0.3 mi northwest of Woodbine.

Basin characteristics:

$\begin{array}{lrllc}\text { Drainage area } & 19.4 \mathrm{mi}^{2} & \text { Forest } & 34 & \text { percent } \\ \text { Length } & 8.1 & \mathrm{mi} & \text { Precipitation } & 41.0 \mathrm{in} . \\ \text { Slope } & 32.8 & \mathrm{ft} / \mathrm{mi} & \text { A Soil } & \text { ND } \\ \text { Elevation } & 714 & \mathrm{ft} & \text { D Soil } & \text { ND } \\ \text { Storage } & 0.14 \text { percent } & & \end{array}$

Low-flow characteristics:

$$
\begin{aligned}
& \text { Discharge } \\
& \left(\mathrm{ft}^{3} / \mathrm{s}\right) \\
& \text { 7-day } \\
& \text { 14-day } \\
& \text { 30-day }
\end{aligned}
$$

$$
\text { - }
$$

Basis of low-flow estimates:

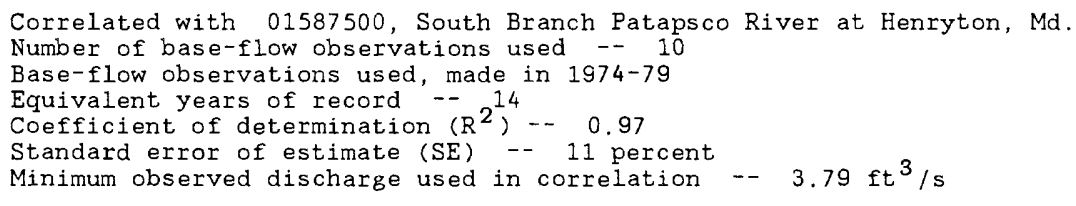

\section{Stony Run at Elkridge, Md.}

Location: Lat $39^{\circ} 12^{\prime} 43^{\prime \prime}$, Long $76^{\circ} 41^{\prime} 46^{\prime \prime}$, Howard County, at highway bridge on Elkridge-Patapsco Road, $0.9 \mathrm{mi}$ east of Elkridge.

Basin characteristics:

Drainage area
Length
Slope
Elevation
Storage

$\begin{array}{rl}9.56 \mathrm{mi}^{2} \\ 6.4 \mathrm{mi} \\ 22.1 \mathrm{ft} / \mathrm{mi} \\ 136 & \mathrm{ft} \\ 1.83 & \text { percent }\end{array}$

$\begin{array}{lr}\text { Forest } & 3 * \text { percent } \\ \text { Precipitation } & 42.0 \text { in. } \\ \text { A Soil } & \text { ND } \\ \text { D Soil } & \text { ND }\end{array}$

Low-flow characteristics:

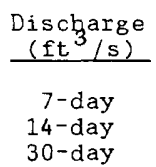

\begin{tabular}{lcc}
\multicolumn{3}{c}{ Recurrence interval } \\
\cline { 1 - 1 } 2-year & 10-year & 20-year \\
4.6 & 2.8 & 2.4 \\
4.9 & 3.0 & 2.6 \\
5.4 & 3.4 & 3.0
\end{tabular}

Basis of low-flow estimates:

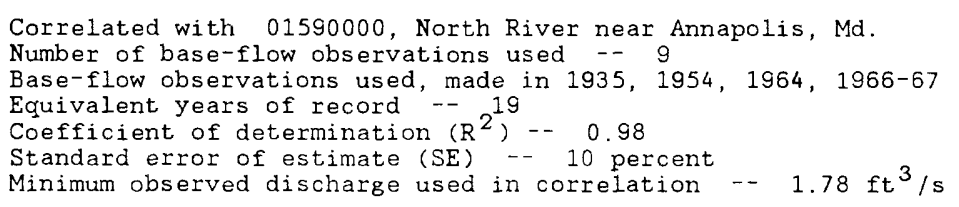


Table 12.--Basin characteristics and low-flow characteristics at partial-record streamflow-gaging stations in Maryland and Delaware--Continued

01589230 Red Run near Owings Mills, Md.

Location: Lat $39^{\circ} 24^{\prime} 17^{\prime \prime}$, long $76^{\circ} 46^{\prime} 45^{\prime \prime}$, Baltimore County, at bridge on Painters Mill Road, 1.1 mi south of Owings Mills.

Basin characteristics:

$\begin{array}{lc}\text { Drainage area } & 7.39 \mathrm{mi}^{2} \\ \text { Length } & 6.0 \mathrm{mi} \\ \text { Slope } & 41.0 \mathrm{ft} / \mathrm{mi} \\ \text { Elevation } & 609 \mathrm{ft} \\ \text { Storage } & 0.05 \text { percent }\end{array}$

$\begin{array}{lr}\text { Forest } & 44 \\ \text { Precipitation } & 44.0 \text { in. } \\ \text { A Soil } & \text { ND } \\ \text { D Soil } & \text { ND }\end{array}$

Storage

0.05 percent

Low-flow characteristics

$$
\begin{gathered}
\begin{array}{c}
\text { Discharge } \\
\left(\mathrm{ft}^{3} / \mathrm{s}\right)
\end{array} \\
\begin{array}{c}
7 \text {-day } \\
14-\text { day } \\
30-\text { day }
\end{array}
\end{gathered}
$$

Basis of low-flow estimates:

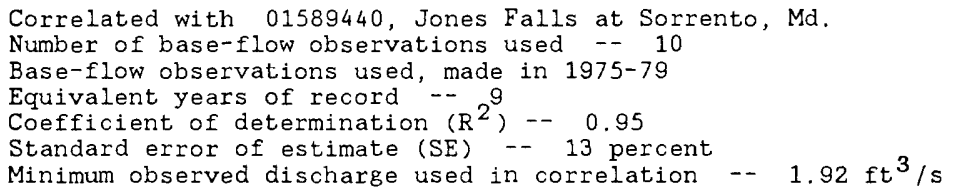

01589500 Sawmi11 Creek at Glen Burnie, Md.

Location: Lat $39^{\circ} 10^{\prime} 12^{\prime \prime}$, long $76^{\circ} 37^{\prime} 51^{\prime \prime}$, Anne Arundel County, 300 ft upstream from bridge on State Highway 648, $0.5 \mathrm{mi}$ northwest of Glen Burnie.

Basin characteristics:

\begin{tabular}{|c|c|c|c|}
\hline Discharge & \multicolumn{3}{|c|}{ Recurrence interval } \\
\hline$\left(\mathrm{ft}^{3} / \mathrm{s}\right)$ & ${ }^{a} 2$-year & $a_{10}$-year & a 20 -year \\
\hline $\begin{array}{r}7-\text { day } \\
14-\text { day } \\
30-\text { day }\end{array}$ & $\begin{array}{l}4.3 \\
4.6 \\
5.0\end{array}$ & $\begin{array}{l}2.7 \\
2.9 \\
3.2\end{array}$ & $\begin{array}{l}2.3 \\
2.4 \\
2.8\end{array}$ \\
\hline
\end{tabular}

$\begin{array}{lclc}\text { Drainage area } & 4.97 \mathrm{mi}^{2} & \text { Forest } & 42 \\ \text { Length } & 4.5 \mathrm{mi} & \text { Precipitation } & 46.0 \mathrm{in} . \\ \text { Slope } & 30.9 \mathrm{ft} / \mathrm{mi} & \text { A Soil } & \text { ND } \\ \text { Elevation } & 119 \mathrm{ft} & \text { D Soil } & \text { ND } \\ \text { Storage } & 0.04 \text { percent } & & \end{array}$

Low-flow characteristics:

$$
\begin{gathered}
\text { Discharge } \\
\frac{\left(\mathrm{ft}^{3} / \mathrm{s}\right)}{\begin{array}{c}
7-\text { day } \\
14-\text { day } \\
30-\text { day }
\end{array}}
\end{gathered}
$$

$\begin{array}{lccc}2 \text { 2-year } & \text { 10-year } & & \text { 20-year } \\ 2.2 & 1.0 & & 0.8 \\ 2.3 & 1.1 & & 0.8 \\ 2.6 & 1.2 & & 1.0\end{array}$

Basis of low-flow estimates:

Correlated with 01590000, North River near Annapolis, Md.

Number of base-flow observations used -- 28 (daily-flow values)

Base-flow observations used, made in 1944-52 (continuous-record station)

Equivalent years of record -- $2^{9}$
Coefficient of determination $\left(R^{2}\right)-0.69$

Standard error of estimate (SE) - 18 percent

Minimum observed discharge used in correlation -- $3.6 \mathrm{ft}^{3} / \mathrm{s}$

a Use low-flow estimates with caution. Estimates are representative of early period of record which was relatively unaffected by regulation/urbanization/aquifer withdrawals, etc. Data not transferrable at site to 1980 's or beyond. 
Table 12.--Basin characteristics and low-flow characteristics at partial-record streamflow-gaging stations in Maryland and Delaware--Continued

01589800 Severn Run at Benfield, Md.

Location: Lat $39^{\circ} 04^{\prime} 51^{\prime \prime}$, long $76^{\circ} 37^{\prime} 36^{\prime \prime}$, Anne Arundel County, at bridge on State Highway 3 , 0.5 mi south of Benfield.

Basin characteristics:

$\begin{array}{lcllc}\text { Drainage area } & 24.0 \mathrm{mi}^{2} & \text { Forest } & 56 \text { percent } \\ \text { Length } & 10.1 \mathrm{mi} & \text { Precipitation } & 44.0 \text { in. } \\ \text { Slope } & 15.0 \mathrm{ft} / \mathrm{mi} & \text { A Soil } & \text { ND } \\ \text { Elevation } & 133 & \mathrm{ft} & \text { D Soil } & \text { ND } \\ \text { Storage } & 0.02 \text { percent } & & \end{array}$

Low-flow characteristics:

\begin{tabular}{|c|c|c|c|}
\hline \multirow{2}{*}{$\begin{array}{c}\text { Discharge } \\
\left(\mathrm{ft}^{3} / \mathrm{s}\right)\end{array}$} & \multicolumn{3}{|c|}{ Recurrence interval } \\
\hline & 2-year & 10-year & 20-year \\
\hline $\begin{array}{r}\text { 7-day } \\
14-\text { day } \\
30-\text { day }\end{array}$ & $\begin{array}{l}14 \\
14 \\
15\end{array}$ & $\begin{array}{l}10 \\
11 \\
12\end{array}$ & $\begin{array}{r}9.4 \\
9.9 \\
11\end{array}$ \\
\hline
\end{tabular}

Basis of $10 w-f l o w$ estimates:

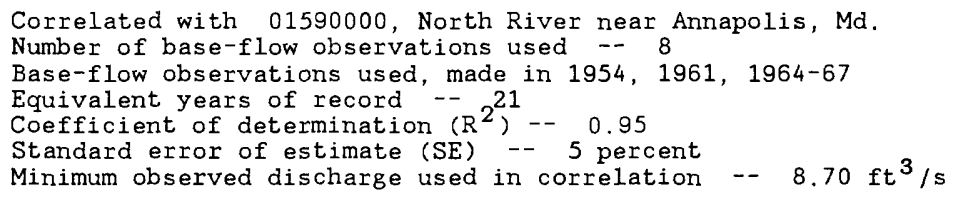

01590900 Cabin Branch near Florence, Md.

Location: Lat $39^{\circ} 16^{\prime} 36^{\prime \prime}$, long $77^{\circ} 06^{\prime} 20^{\prime \prime}$, Howard County, at bridge on Hipsley Mill Road, 2.3 mi south of Florence.

Basin characteristics:

$\begin{array}{lclc}\text { Drainage area } & 8.36 \mathrm{mi}^{2} & \text { Forest } & 27 \text { percent } \\ \text { Length } & 6.4 \mathrm{mi} & \text { Precipitation } & 43.0 \text { in. } \\ \text { Slope } & 38.5 \mathrm{ft} / \mathrm{mi} & \text { A Soil } & \text { ND } \\ \text { Elevation } & 639 \mathrm{ft} & \text { D Soil } & \text { ND } \\ \text { Storage } & 0.16 \text { percent } & & \end{array}$

Low-flow characteristics:

$$
\begin{aligned}
& \text { Discharge } \\
& \left(\mathrm{ft}^{3} / \mathrm{s}\right) \\
& \text { 7-day } \\
& \text { 14-day } \\
& \text { 30-day }
\end{aligned}
$$

\begin{tabular}{lcc}
\multicolumn{3}{c}{ Recurrence interval } \\
\cline { 1 - 1 } 2-year & 10-year & $\frac{20 \text {-year }}{3.1}$ \\
3.1 & 1.2 & 0.9 \\
3.4 & 1.4 & 1.1 \\
3.8 & 1.5
\end{tabular}

Basis of low-flow estimates:

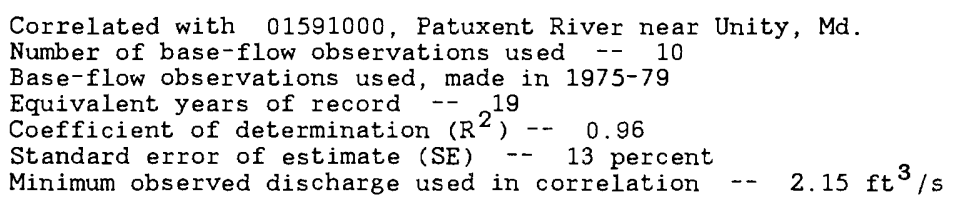


Table 12.--Basin characteristics and low-flow characteristics at partial-record streamflow-gaging stations in Maryland and Delaware--Continued

01591350 Cattail Creek near Cooksville, Md.

Location: Lat $39^{\circ} 18^{\prime} 50^{\prime \prime}$, long $77^{\circ} 03^{\prime} 15^{\prime \prime}$, Howard County, at bridge on Bushy Park Road, 2.3 mi west of Cooksville.

Basin characteristics:

\begin{tabular}{|c|c|}
\hline $\begin{array}{l}\text { Drainage area } \\
\text { Length } \\
\text { Slope } \\
\text { Elevation } \\
\text { Storage }\end{array}$ & $\begin{array}{rl}8.37 \mathrm{mi}^{2} & \\
4.2 & \mathrm{mi} \\
62.0 & \mathrm{ft} / \mathrm{mi} \\
603 & \mathrm{ft} \\
0.38 & \text { percent }\end{array}$ \\
\hline
\end{tabular}

$\begin{array}{lrl}\text { Forest } & 17 & \text { percent } \\ \text { Precipitation } & 43.0 \text { in. } \\ \text { A Soil } & \text { ND } \\ \text { D Soil } & \text { ND }\end{array}$

Low-flow characteristics:

$\begin{gathered}\text { Discharge } \\ \left(\mathrm{ft}^{3} / \mathrm{s}\right)\end{gathered}$
$\begin{gathered}7-\text { day } \\ 14-\text { day } \\ 30-\text { day }\end{gathered}$

Basis of low-flow estimates:

Correlated with 01591000, Patuxent River near Unity, Md.

Number of base-flow observations used -- 27 (daily-flow values)

Base-flow observations used, made in 1977-81 (continuous-record station)

Equivalent years of record -- 19

Coefficient of determination $\left(\mathrm{R}^{2}\right)-0.98$

Standard error of estimate (SE) -- 11 percent

Minimum observed discharge used in correlation -- $1.5 \mathrm{ft}^{3} / \mathrm{s}$

01591650 Hawlings River near Unity. Md.

Location: Lat $39^{\circ} 13^{\prime} 03^{\prime \prime}$, long $77^{\circ} 06^{\prime} 21^{\prime \prime}$, Montgomery County, at bridge on Sundown Road, 2.2 mi southwest of Unity.

Basin characteristics:

Drainage area
Length
Slope
Elevation
Storage

$5.08 \mathrm{mi}^{2}$
$4.0 \mathrm{mi}$
$39.3 \mathrm{ft} / \mathrm{mi}$
$554 \mathrm{ft}$
0.24 percent

Forest

23 percent

Length

Storage

0.24 percent

Precipitation $42.5 \mathrm{in.}$

A Soil ND

D Soil

ND

Low-flow characteristics:

$\begin{gathered}\text { Discharge } \\ \left(\mathrm{ft}^{3} / \mathrm{s}\right)\end{gathered}$
$\begin{gathered}7-\text { day } \\ 14-\text { day } \\ 30-\text { day }\end{gathered}$

\begin{tabular}{|c|c|c|}
\hline \multicolumn{3}{|c|}{ Recurrence interval } \\
\hline 2-year & 10 -year & 20 -year \\
\hline 1.2 & 0.4 & 0.3 \\
\hline 1.2 & 0.5 & 0.3 \\
\hline 1.3 & 0.6 & 0.5 \\
\hline
\end{tabular}

Basis of low-flow estimates:

Correlated with 01591000 , Patuxent River near Unity, Md.

Number of base-flow observations used -- 13

Base-flow observations used, made in 1977-82

Equivalent years of record --
Coefficient of determination $\left(\mathrm{R}^{2}\right)-0.96$

Standard error of estimate (SE) -- 18 percent

Minimum observed discharge used in correlation -- $0.42 \mathrm{ft}^{3} / \mathrm{s}$ 
Table 12.--Basin characteristics and low-flow characteristics at partial-record streamflow-gaging stations in Maryland and Delaware--Continued

01591700 Hawlings River near Sandy Spring, Md.

Location: "Lat $39^{\circ} 10^{\prime} 28^{\prime \prime}$, long $77^{\circ} 01^{\prime} 18^{\prime \prime}$, Montgomery County, at bridge on State Highway $650,1.7 \mathrm{mi}$ north of Sandy Spring.

Basin characteristics:

$\begin{array}{lcl}\text { Drainage area } & 27.2 \mathrm{mi}^{2} \\ \text { Length } & 10.6 \mathrm{mi} \\ \text { Slope } & 26.0 \mathrm{ft} / \mathrm{mi} \\ \text { Elevation } & 504 & \mathrm{ft} \\ \text { Storage } & 0.25 \text { percent }\end{array}$

$\begin{array}{lr}\text { Forest } & 21 \text { percent } \\ \text { Precipitation } & 42.0 \text { in. } \\ \text { A Soil } & \text { ND } \\ \text { D Soil } & \text { ND }\end{array}$

$\begin{array}{ll}\text { A Soil } & \text { ND } \\ \text { D Soil } & \text { ND }\end{array}$

Low-flow characteristics:

\begin{tabular}{|c|}
\hline $\begin{array}{l}\text { Discharge } \\
\left(\mathrm{ft}^{3} / \mathrm{s}\right)\end{array}$ \\
\hline $\begin{array}{l}\text { 7-day } \\
14 \text {-day } \\
30 \text {-day }\end{array}$ \\
\hline
\end{tabular}

Basis of low-flow estimates:

Correlated with 01591000 , Patuxent River near Unity, Md.

Number of base-flow observations used -- 7 (discharge measurements)

20 (daily-flow values)

Base-flow observations used, made in 1975-78 (partial-record station)

Equivalent years of record -- 1979-87 (continuous-record station)

Equivalent years of record --
Coefficient of determination $\left(\mathrm{R}^{2}\right)--\quad 0.97$

Standard error of estimate (SE) -- 13 percent

Minimum observed discharge used in correlation -- $2.6 \mathrm{ft}^{3} / \mathrm{s}$

* Revised.

01593200 Little Patuxent River at Pine Orchard, Md.

Location: Lat $39^{\circ} 16^{\prime} 42^{\prime \prime}$, long $76^{\circ} 51^{\prime} 11^{\prime \prime}$, Howard County, at bridge on U.S. Highway $40,0.4 \mathrm{mi}$ east of Pine Orchard.

Basin characteristics:

Drainage area
Length
Slope
Elevation
Storage

$\begin{array}{cl}7.03 \mathrm{mi}^{2} \\ 7.3 \mathrm{mi} \\ 31.2 \mathrm{ft} / \mathrm{mi} \\ 481 & \mathrm{ft} \\ 0.01 & \text { percent }\end{array}$

$\begin{array}{lrr}\text { Forest } & 34 & \text { percent } \\ \text { Precipitation } & 43.5 & \text { in. } \\ \text { A Soil } & \text { ND } & \\ \text { D Soil } & \text { ND }\end{array}$

Low-flow characteristics:

Discharge
$\left(\mathrm{ft}^{3} / \mathrm{s}\right)$
$\begin{gathered}7 \text {-day } \\ 14-\text { day } \\ 30-\text { day }\end{gathered}$

\begin{tabular}{|c|c|c|}
\hline 2-year & 10 -year & 20-year \\
\hline 2.4 & 0.9 & 0.6 \\
\hline 2.4 & 1.0 & 0.8 \\
\hline 2.5 & 1.3 & 1.1 \\
\hline
\end{tabular}

Basis of low-flow estimates:

Correlated with 01587500, South Branch Patapsco River at Henryton, Md.

Number of base-flow observations used -- 13

Base-flow observations used, made in 1956-59, 1961-63, 1966

Equivalent years of record --
Coefficient of determination $\left(R^{2}\right)--0.98$

Standard error of estimate (SE) - 9 percent
Minimum observed discharge used in correlation -- $1.14 \mathrm{ft}^{3} / \mathrm{s}$ 
Table 12.--Basin characteristics and low-flow characteristics at partial-record streamflow-gaging stations in Maryland and Delaware--Continued

\section{Middle Patuxent River near West Friendship, Md.}

Location: Lat $39^{\circ} 17^{\prime} 14^{\prime \prime}$, Long $76^{\circ} 57^{\prime} 33^{\prime \prime}$, Howard County, at bridge on State Highway 32 , 1.1 mi south of West Friendship.

\section{Basin characteristics:}

Drainage area
Length
Slope
Elevation
Storage

$\begin{array}{rl}11.4 & \mathrm{mi}^{2} \\ 5.4 & \mathrm{mi} \\ 37.3 & \mathrm{ft} / \mathrm{mi} \\ 557 & \mathrm{ft} \\ 0.06 & \text { percent }\end{array}$

$\begin{array}{lr}\text { Forest } & 19 \text { percent } \\ \text { Precipitation } & 43.0 \text { in. } \\ \text { A Soil } & \text { ND } \\ \text { D Soil } & \text { ND }\end{array}$

Low-flow characteristics:

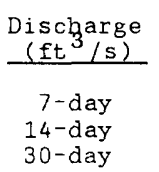

\begin{tabular}{|c|c|c|}
\hline \multicolumn{3}{|c|}{ Recurrence interval } \\
\hline 2-year & 10 -year & 20 -year \\
\hline 3.8 & 1.5 & 1.0 \\
\hline 3.9 & 1.7 & 1.3 \\
\hline 4.0 & 2.1 & 1.7 \\
\hline
\end{tabular}

Basis of low-flow estimates:

Correlated with 01587500, South Branch Patapsco River at Henryton, Md.

Number of base-flow observations used - 13

Base-flow observations used, made in 1956-59, 1961-63

Equivalent years of record -- 14

Coefficient of determination $\left(\mathrm{R}^{2}\right)-0.99$

Standard error of estimate (SE) - 8 percent

Minimum observed discharge used in correlation -- $1.72 \mathrm{ft}^{3} / \mathrm{s}$

\section{Middle Patuxent River Tributary near Dayton, Md.}

Location: Lat $39^{\circ} 14^{\prime} 12^{\prime \prime}$, long $76^{\circ} 56^{\prime} 27^{\prime \prime}$, Howard County, at bridge on Sheppard Road, $2.5 \mathrm{mi}$ east of Dayton.

Basin characteristics:

Drainage area
Length
Slope
Elevation
Storage

$$
\begin{array}{cl}
4.25 \mathrm{mi}^{2} \\
4.1 \mathrm{mi} \\
59.4 & \mathrm{ft} / \mathrm{mi} \\
552 & \mathrm{ft} \\
0.23 & \text { percent }
\end{array}
$$

\begin{tabular}{|c|c|c|}
\hline 2-year & 10-year & 20-year \\
\hline 1.3 & 0.6 & 0.4 \\
\hline 1.3 & 0.7 & 0.5 \\
\hline 1.4 & 0.8 & 0.7 \\
\hline
\end{tabular}

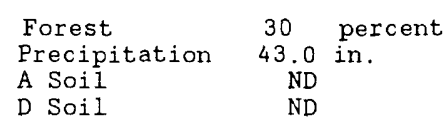

Low-flow characteristics:

$$
\begin{gathered}
\begin{array}{c}
\text { Discharge } \\
\left(\mathrm{ft}^{3} / \mathrm{s}\right)
\end{array} \\
\begin{array}{c}
7 \text {-day } \\
14-\text { day } \\
30-\text { day }
\end{array}
\end{gathered}
$$

\section{Basis of low-flow estimates:}

Correlated with 01591000, Patuxent River near Unity, Md.

Number of base-flow observations used -. 12

Base-flow observations used, made in 1977-82

Equivalent years of record -- 17

Coefficient of determination $\left(\mathrm{R}^{2}\right)-0.95$

Standard error of estimate (SE) - 14 percent

Minimum observed discharge used in correlation -- $0.69 \mathrm{ft}^{3} / \mathrm{s}$ 
Table 12.--Basin characteristics and low-flow characteristics at partial-record streamflow-gaging stations in Maryland and Delaware--Continued

01594100 Hammond Branch at Scaggsville, Md.

Location: Lat $39^{\circ} 09^{\prime} 13^{\prime \prime}$, long $76^{\circ} 53^{\prime} 35^{\prime \prime}$, Howard County, at bridge on U.S. Highway $29,0.7$ mi northeast of Scaggsvilie.

Basin characteristics:

Drainage area
Length
Slope
Elevation
Storage

$\begin{array}{rl}3.01 \mathrm{mi}^{2} \\ 3.4 & \mathrm{mi} \\ 42.5 & \mathrm{ft} / \mathrm{mi} \\ 446 & \mathrm{ft} \\ 0.0 & \text { percent }\end{array}$

$\begin{array}{lc}\text { Forest } & 19 \\ \text { Precipitation } & 44.0 \text { in. } \\ \text { A Soil } & \text { ND } \\ \text { D Soil } & \text { ND }\end{array}$

Low-flow characteristics:

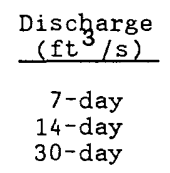

\begin{tabular}{|c|c|c|}
\hline 2-year & 10 -year & 20 -year \\
\hline 0.9 & 0.4 & 0.3 \\
\hline 0.9 & 0.4 & 0.3 \\
\hline 1.0 & 0.5 & 0.4 \\
\hline
\end{tabular}

Basis of low-flow estimates:

Correlated with 01591000, Patuxent River near Unity, Md.

Number of base-flow observations used -- 14

Base-flow observations used, made in 1956-59, 1962-63, 1966

Equivalent years of record -- 13

Coefficient of determination $\left(R^{2}\right)--0.92$

Standard error of estimate (SE) -- 20 percent

Minimum observed discharge used in correlation -- $0.27 \mathrm{ft}^{3} / \mathrm{s}$

01594455 Socketts Run near Hardesty, Md.

Location: Lat $38^{\circ} 52^{\prime} 58^{\prime \prime}$, long $76^{\circ} 39^{\prime} 47^{\prime \prime}$, Anne Arundel County, at bridge on Sands Road, 1.3 mi southeast of Hardesty.

Basin characteristics:

Drainage area
Length
Slope
Elevation
Storage

$\begin{array}{ll}6.68 \mathrm{mi}^{2} \\ 5.0 \mathrm{mi} \\ 20.9 \mathrm{ft} / \mathrm{mi} \\ 120 & \mathrm{ft} \\ 0.12 & \text { percent }\end{array}$

$\begin{array}{lr}\text { Forest } & 45 \text { percent } \\ \text { Precipitation } & 44.0 \text { in. } \\ \text { A Soil } & \text { ND } \\ \text { D Soil } & \text { ND }\end{array}$

Low-flow characteristics:

\begin{tabular}{c} 
Discbarge \\
$\left(\mathrm{ft}^{3} / \mathrm{s}\right)$ \\
\hline $\begin{array}{l}7-\text { day } \\
14-\text { day } \\
30-\text { day }\end{array}$
\end{tabular}

Basis of low-flow estimates:

Correlated with 01591000, Patuxent River near Unity, Md.

Number of base-flow observations used -- 10

Base-flow observations used, made in 1977-81

Equivalent years of record -- 13

Coefficient of determination $\left(R^{2}\right)-0.96$

Standard error of estimate (SE) - 33 percent
Minimum observed discharge used in correlation -- $0.11 \mathrm{ft}^{3} / \mathrm{s}$ 
Table 12.--Basin characteristics and low-flow characteristics at partial-record streamflow-gaging stations in Maryland and Delaware--Continued

01594975 Glade Run at Steyer, Md.

Location: Lat $39^{\circ} 18^{\prime} 08^{\prime \prime}$, long $79^{\circ} 19^{\prime} 33^{\prime \prime}$, Garrett County, at culvert on Steyer-Gorman Road, 0.7 mi west of Steyer.

Basin characteristics:

Drainage area
Length
Slope
Elevation
Storage

$\begin{array}{cl}8.86 \mathrm{mi}^{2} \\ 4.0 \mathrm{mi} \\ 104 & \mathrm{ft} / \mathrm{mi} \\ 2,680 & \mathrm{ft} \\ 0.09 & \text { percent }\end{array}$

$\begin{array}{lc}\text { Forest } & 53 \\ \text { Precipitation } & 47.0 \text { in. } \\ \text { A Soil } & \text { ND } \\ \text { D Soil } & \text { ND }\end{array}$

Low-flow characteristics:

\begin{tabular}{|c|c|c|c|}
\hline \multirow{2}{*}{$\begin{array}{c}\text { Discharge } \\
\left(\mathrm{ft}^{3} / \mathrm{s}\right) \\
\end{array}$} & \multicolumn{3}{|c|}{ Recurrence interval } \\
\hline & 2-year & 10 -year & 20 -year \\
\hline $\begin{array}{r}\text { 7-day } \\
14-\text { day } \\
30-\text { day }\end{array}$ & $\begin{array}{l}0.5 \\
0.6 \\
0.8\end{array}$ & $\begin{array}{l}0.1 \\
0.1 \\
0.2\end{array}$ & $\begin{array}{l}0.07 \\
0.08 \\
0.1\end{array}$ \\
\hline
\end{tabular}

Basis of low-flow estimates:

Correlated with 03075500 , Youghiogheny River near Oakland, Md.

Number of base-flow observations used -- 13

Base-flow observations used, made in 1977-82

Equivalent years of record --
Coefficient of determination $\left(\mathrm{R}^{2}\right)--0.95$

Standard error of estimate (SE) -- 25 percent

Minimum observed discharge used in correlation -- $0.54 \mathrm{ft}^{3} / \mathrm{s}$

01596200 I.ittle Savage River near Avilton, Md.

Location: Lat $39^{\circ} 36^{\prime} 59^{\prime \prime}$, long 79.01'29", Garrett County, at bridge on Avilton-Lonaconing Road, $1.7 \mathrm{mi}$ north of Mt. Zion Church.

Basin characteristics:

$\begin{array}{lclcc}\text { Drainage area } & 1.95 \mathrm{mi}^{2} & \text { Forest } & 95 & \text { percent } \\ \text { Length } & 3.0 \mathrm{mi} & \text { Precipitation } & 42.5 \mathrm{in} . \\ \text { Slope } & 40.8 \mathrm{ft} / \mathrm{mi} & \text { A Soil } & \text { ND } \\ \text { Elevation } & 2,740 \quad \mathrm{ft} & \text { D Soil } & \text { ND } \\ \text { Storage } & 4.15 \text { percent } & & \end{array}$

Low-flow characteristics:

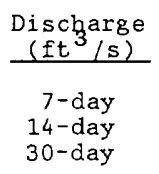

\begin{tabular}{lcr}
\multicolumn{3}{c}{ Recurrence interval } \\
2 2-year & 10-year & 20-year \\
0.02 & $<0.005$ & $<0.005$ \\
0.02 & 0.01 & $<0.005$ \\
0.04 & 0.01 & 0.01
\end{tabular}

Basis of low-flow estimates:

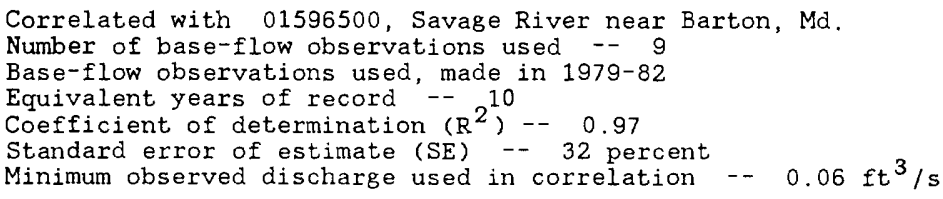


Table 12,--Basin characteristics and low-flow characteristics at partial-record streamflow-gaging stations in Maryland and Delaware--Continued

01596600 Big Rum near Swanton, Md.

Location: Lat $39^{\circ} 32^{\prime} 45^{\prime \prime}$, long $79^{\circ} 08^{\prime} 31^{\prime \prime}$, Garrett County, at culvert on Big Run Road, 7.5 mi northeast of Swanton.

Basin characteristics:

Drainage area
Length
Slope
Elevation
Storage

$\begin{array}{cl}13.4 & \mathrm{mi}^{2} \\ 5.6 & \mathrm{mi} \\ 206 & \mathrm{ft} / \mathrm{mi} \\ 2,310 & \mathrm{ft} \\ 0.0 & \text { percent }\end{array}$

$\begin{array}{lr}\text { Forest } & 83 \text { percent } \\ \text { Precipitation } & 44.0 \text { in. } \\ \text { A Soil } & \text { ND } \\ \text { D Soil } & \text { ND }\end{array}$

Low-flow characteristics:

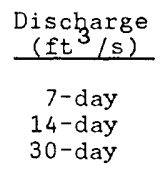

\begin{tabular}{|c|c|c|}
\hline 2-year & 10 -year & 20 -year \\
\hline 0.6 & 0.3 & 0.3 \\
\hline 0.6 & 0.3 & 0.3 \\
\hline 0.7 & 0.4 & 0.3 \\
\hline
\end{tabular}

Basis of low-flow estimates:

Correlated with 01597000, Crabtree Creek near Swanton, Md.

Number of base-flow observations used - 9

Base-flow observations used, made in 1977-81

Equivalent years of record -- 10

Coefficient of determination $\left(\mathrm{R}^{2}\right)-0.90$

Standard error of estimate (SE) -- 35 percent

Minimum observed discharge used in correlation -- $0.42 \mathrm{ft}^{3} / \mathrm{s}$

\section{Middle Fork near Swanton, Md.}

Location: Lat $39^{\circ} 30^{\prime} 46^{\prime \prime}$, long $79^{\circ} 09^{\prime} 17^{\prime \prime}$, Garrett County, at culvert on Savage River Road, $5.5 \mathrm{mi}$ northeast of Swanton.

Basin characteristics:

Drainage area
Length
Slope
Elevation
Storage

$\begin{array}{rl}10.8 & \mathrm{mi}^{2} \\ 6.3 & \mathrm{mi} \\ 145 & \mathrm{ft} / \mathrm{mi} \\ 2,620 & \mathrm{ft} \\ 0.0 & \text { percent }\end{array}$

$\begin{array}{lr}\text { Forest } & 75 \text { percent } \\ \text { Precipitation } & 44.0 \text { in. } \\ \text { A Soil } & \text { ND } \\ \text { D Soil } & \text { ND }\end{array}$

Low-flow characteristics:

Discharge
$\left(\mathrm{ft}^{3} / \mathrm{s}\right)$
$\begin{gathered}7-\text { day } \\ 14-\text { day } \\ 30-\text { day }\end{gathered}$

\section{Basis of low-flow estimates:}

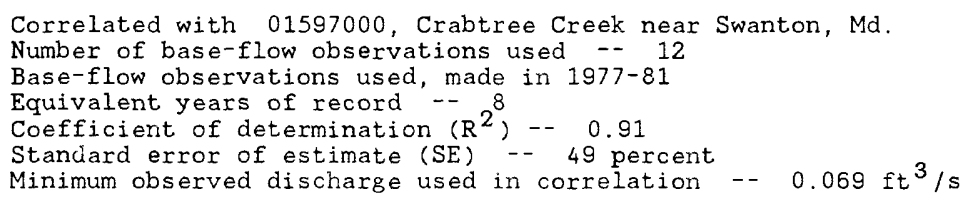


Table 12.--Basin characteristics and low-flow characteristics at partial-record streamflow-gaging stations in Maryland and Delaware--Continued

01598980 Mill Rum at Morrison, Md.

Location: Lat $39^{\circ} 31^{\prime} 03^{\prime \prime}$, long $79^{\circ} 01^{\prime} 44^{\prime \prime}$, Allegany County, at bridge on county highway, 0.5 mi northwest of Morrison.

Basin characteristics:

$\begin{array}{lclll}\text { Drainage area } & 7.35 \mathrm{mi}^{2} & \text { Forest } & 76 & \text { percent } \\ \text { Length } & 5.0 & \mathrm{mi} & \text { Precipitation } & 41.0 \text { in. } \\ \text { Slope } & 329 & \mathrm{ft} / \mathrm{mi} & \text { A Soil } & \text { ND } \\ \text { Elevation } & 2,190 & \mathrm{ft} & \text { D Soil } & \text { ND } \\ \text { Storage } & 0.005 \text { percent } & & \end{array}$

Low-flow characteristics:

$$
\begin{aligned}
& \begin{array}{c}
\text { Discharge } \\
\left(\mathrm{ft}^{3} / \mathrm{s}\right)
\end{array} \\
& \text { 7-day } \\
& \text { 14-day } \\
& \text { 30-day }
\end{aligned}
$$

\begin{tabular}{ccc}
\multicolumn{3}{c}{ Recurrence interval } \\
\cline { 1 - 2 }$\frac{10 \text {-year }}{3} \frac{20 \text {-yea }}{0.4}$ & 0.2 & 0.1 \\
0.5 & 0.2 & 0.2 \\
0.7 & 0.3 & 0.3
\end{tabular}

Basis of low-flow estimates:

Correlated with 01596500, Savage River near Barton, Md.

Number of base-flow observations used -- 11

Base-flow observations used, made in 1979-82

Equivalent years of record --
Coefficient of determination $\left(R^{2}\right)--0.92$

Standard error of estimate (SE) -- 30 percent

Minimum observed discharge used in correlation -- $0.74 \mathrm{ft}^{3} / \mathrm{s}$

01601325 Jennings Rum at Corriganville, Md.

Location: Lat $39^{\circ} 41^{\prime} 36^{\prime \prime}$, long $78^{\circ} 47^{\prime} 17^{\prime \prime}$, Allegany County, at bridge on State Highway 36 , at Corriganvilie, Md.

Basin characteristics:

$\begin{array}{lcllc}\text { Drainage area } & 37.7 \mathrm{mi}^{2} & \text { Forest } & 75 \mathrm{percent} \\ \text { Length } & 12.6 \mathrm{mi} & \text { Precipitation } & 40.5 \mathrm{in} . \\ \text { Slope } & 138 & \mathrm{ft} / \mathrm{mi} & \text { A Soil } & \text { ND } \\ \text { Elevation } & 1,790 \mathrm{ft} & \text { D Soil } & \text { ND } \\ \text { Storage } & 0.02 \text { percent } & & \end{array}$

Low-flow characteristics:

$\begin{gathered}\text { Discharge } \\ \left(\mathrm{ft}^{3} / \mathrm{s}\right)\end{gathered}$
$\begin{gathered}7-\text { day } \\ 14-\text { day } \\ 30-\text { day }\end{gathered}$

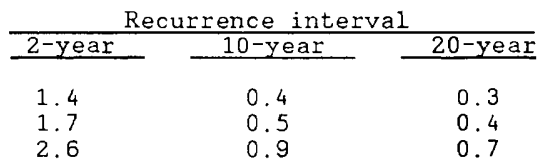

Basis of low-flow estimates:

Correlated with 01596500, Savage River near Barton, Md.

Number of base-flow observations used -- 10

Base-flow observations used, made in 1975-77

Equivalent years of record -- 15

Coefficient of determination $\left(R^{2}\right)--0.97$

Standard error of estimate (SE) - 28 percent
Minimum observed discharge used in correlation -- $1.12 \mathrm{ft}^{3} / \mathrm{s}$ 
Table 12.--Basin characteristics and low-flow characteristics at partial-record streamflow-gaging stations in Maryland and Delaware--Continued

01605425 Mill Run at Oldtown, Md.

Location: Lat $39^{\circ} 32^{\prime} 26^{\prime \prime}$, long $78^{\circ} 36^{\prime} 43^{\prime \prime}$, Allegany County, at highway bridge, $0.1 \mathrm{mi}$ south of Oldtown.

Basin characteristics:

$\begin{array}{lrllc}\text { Drainage area } & 10.6 \mathrm{mi}^{2} & \text { Forest } & 80 & \text { percent } \\ \text { Length } & 10.3 \mathrm{mi} & \text { Precipitation } & 37.0 \mathrm{in} . \\ \text { Slope } & 94.3 \mathrm{ft} / \mathrm{mi} & \text { A Soil } & \text { ND } \\ \text { Elevation } & 1,150 \mathrm{ft} & \text { D Soil } & \text { ND } \\ \text { Storage } & 0.01 \text { percent } & & \end{array}$

Low-flow characteristics:

Discharge
$\left(\mathrm{ft}^{3} / \mathrm{s}\right)$
$\begin{gathered}7 \text {-day } \\ \text { 14-day } \\ 30-\text { day }\end{gathered}$

\begin{tabular}{|c|c|c|}
\hline 2-year & 10 -year & 20-year \\
\hline 0.3 & 0.2 & 0.1 \\
\hline 0.3 & 0.2 & 0.2 \\
\hline 0.4 & 0.2 & 0.2 \\
\hline
\end{tabular}

Basis of low-flow estimates:

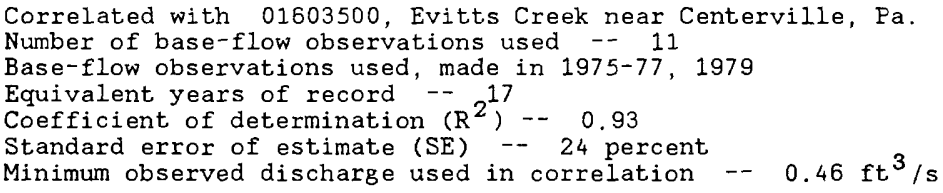

01608975 Maple Rum near Town Creek, Md.

Location: Lat $39^{\circ} 36^{\prime} 46^{\prime \prime}$, long $78^{\circ} 31^{\prime} 52^{\prime \prime}$, Allegany County, at highway bridge on Jacobs Road, 6.0 mi north of Town Creek.

Basin characteristics:

$\begin{array}{lcllc}\text { Drainage area } & 7.10 \mathrm{mi}^{2} & \text { Forest } & 100 & \text { percent } \\ \text { Length } & 3.6 \mathrm{mi} & \text { Precipitation } & 36.5 \mathrm{in} . \\ \text { Slope } & 125 & \mathrm{ft} / \mathrm{mi} & \text { A Soil } & \text { ND } \\ \text { Elevation } & 1,020 & \mathrm{ft} & \text { D Soil } & \text { ND } \\ \text { Storage } & 0.0 \mathrm{percent} & & \end{array}$

Low-flow characteristics:

$$
\begin{aligned}
& \text { Discharge } \\
& \text { 7-day } \\
& \text { 14-day } \\
& \text { 30-day }
\end{aligned}
$$

\begin{tabular}{lcc}
\multicolumn{3}{c}{ Recurrence interval } \\
\cline { 1 - 1 } 2 2-year & 10-year & $\frac{20 \text {-year }}{20}$ \\
0.0 & 0.0 & 0.0 \\
0.0 & 0.0 & 0.0 \\
0.0 & 0.0 & 0.0
\end{tabular}

\section{Basis of low-flow estimates:}

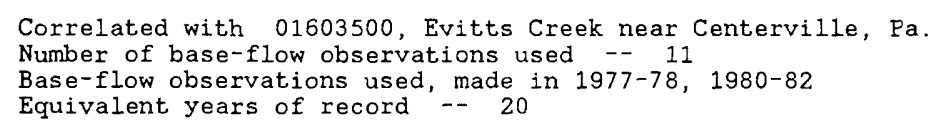

Remarks. Too few discharge observations $>0.0 \mathrm{ft}^{3} / \mathrm{s}$ (6) to warrant determination of regression relation. 
Table 12. --Basin characteristics and low-flow characteristics at partial-record streamflow-gaging stations in Maryland and Delaware--Continued

\section{Fifteen Mile Creek near Piney Grove, Hd.}

Location: Lat $39^{\circ} 41^{\prime} 13^{\prime \prime}$, long $78^{\circ} 27^{\prime} 17^{\prime \prime}$, Allegany County, at highway bridge, 4.3 mi southwest of Piney Grove.

Basin characteristics:

Drainage area
Length
Slope
Elevation
Storage

$\begin{array}{rl}20.2 & \mathrm{mi}^{2} \\ 9.4 & \mathrm{mi} \\ 60.4 & \mathrm{ft} / \mathrm{mi} \\ 1,150 & \mathrm{ft} \\ 0.03 & \text { percent }\end{array}$

$\begin{array}{lc}\text { Forest } & 90 \text { percent } \\ \text { Precipitation } & 37.0 \text { in. } \\ \text { A Soil } & \text { ND } \\ \text { D Soil } & \text { ND }\end{array}$

Low-flow characteristics:

\begin{tabular}{|c|}
\hline $\begin{array}{c}\text { Discharge } \\
\left(\mathrm{ft}^{3} / \mathrm{s}\right)\end{array}$ \\
\hline $\begin{array}{r}\text { 7-day } \\
14-\text { day } \\
30-\text { day }\end{array}$ \\
\hline
\end{tabular}

\begin{tabular}{|c|c|c|}
\hline 2-year & 10 -year & 20-year \\
\hline $\begin{array}{l}0.1 \\
0.1 \\
0.2\end{array}$ & $\begin{array}{l}0.01 \\
0.02 \\
0.02\end{array}$ & $\begin{array}{l}0.01 \\
0.01 \\
0.01\end{array}$ \\
\hline
\end{tabular}

\section{Basis of low-flow estimates:}

Correlated with 01609000 , Town Creek near Oldtown, Md.

Number of base-flow observations used -- 12

Base-flow observations used, made in 1975-79

Equivalent years of record - 5

Coefficient of determination $\left(\mathrm{R}^{2}\right)--0.90$

Standard error of estimate (SE) - 58 percent

Minimum observed discharge used in correlation -- $0.08 \mathrm{ft}^{3} / \mathrm{s}$

01610065 Deep Run near I.ittle Orleans, Md.

Location: Lat $39^{\circ} 39^{\prime} 12^{\prime \prime}$, long $78^{\circ} 27^{\prime} 09^{\prime \prime}$, Allegany County, at highway bridge, $3.9^{\mathrm{mi}}$ northwest of Little Orleans.

Basin characteristics:

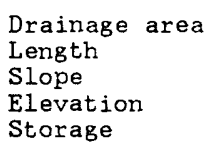

$\begin{array}{rl}6.26 & \mathrm{mi}^{2} \\ 6.5 & \mathrm{mi} \\ 94.5 & \mathrm{ft} / \mathrm{mi} \\ 1,220 & \mathrm{ft} \\ 0.005 & \text { percent }\end{array}$

$\begin{array}{lcc}\text { Forest } & 94 & \text { percent } \\ \text { Precipitation } & 36.5 \text { in. } \\ \text { A Soil } & \text { ND } \\ \text { D Soil } & \text { ND }\end{array}$

Low-flow characteristics:

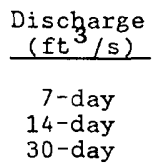

\begin{tabular}{|c|c|c|}
\hline 2-year & 10-year & 20 -year \\
\hline $\begin{array}{l}0.0 \\
0.0 \\
0.0\end{array}$ & $\begin{array}{l}0.0 \\
0.0 \\
0.0\end{array}$ & $\begin{array}{l}0.0 \\
0.0 \\
0.0\end{array}$ \\
\hline
\end{tabular}

Basis of low-flow estimates:

Correlated with 01603500 , Evitts Creek near Centerville, Pa.

Number of base-flow observations used -. 9

Base-flow observations used, made in 1975-77, 1979

Equivalent years of record --
Coefficient of determination $\left(\mathrm{R}^{2}\right)--0.89$

Standard error of estimate (SE) - 69 percent

Minimum observed discharge used in correlation -- $0.0 \mathrm{ft}^{3} / \mathrm{s}$ ( 2 observations)

Remarks. Observations of zero flow not used in regression analysis. 
Table 12.--Basin characteristics and low-flow characteristics at partial-record streamflow-gaging stations in Maryland and Delaware--Continued

01610075 Fifteen Mile Creek at Little Orleans, Md.

Location: Lat $39^{\circ} 37^{\prime} 41^{\prime \prime}$, long $78^{\circ} 23^{\prime} 22^{\prime \prime}$, Allegany County, at highway bridge, at Little Orleans.

Basin characteristics:

Drainage area
Length
Slope
Elevation
Storage

$\begin{array}{rl}61.6 & \mathrm{mi}^{2} \\ 19.1 & \mathrm{mi} \\ 36.9 & \mathrm{ft} / \mathrm{mi} \\ 1,080 & \mathrm{ft} \\ 0.02 & \text { percent }\end{array}$

Forest

A Soil

36.5 in.

D Soil

ND

Storage

0.02 percent

Low-flow characteristics:

$$
\frac{\begin{array}{c}
\text { Discharge } \\
\left(\mathrm{ft}^{3} / \mathrm{s}\right)
\end{array}}{\begin{array}{c}
7-\text { day } \\
14-\text { day } \\
30-\text { day }
\end{array}}
$$

\begin{tabular}{lccc}
\multicolumn{3}{c}{ Recurrence interval } \\
\cline { 1 - 1 } 2-year & 10-year & 20-yeax \\
0.2 & 0.03 & & 0.01 \\
0.3 & 0.03 & & 0.02 \\
0.5 & 0.05 & & 0.03
\end{tabular}

Basis of low-flow estimates:

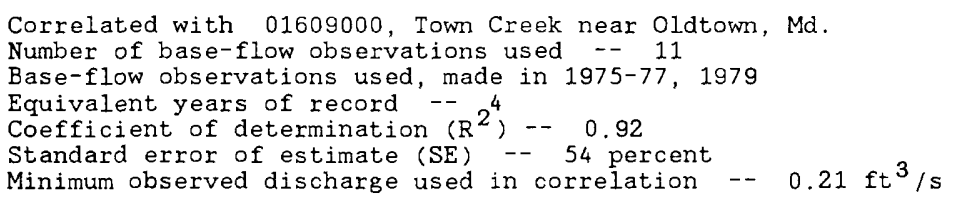

01610150 Bear Creek at Forest Park, Md.

Location: Lat $39^{\circ} 42^{\prime} 07^{\prime \prime}$, long $78^{\circ} 19^{\prime} 02^{\prime \prime}$, Washington County, at culvert on U.S. Highway $40,0.9 \mathrm{mi}$ west of Forest Park.

Basin characteristics:

$\begin{array}{lrl}\text { Drainage area } & 10.4 \mathrm{mi}^{2} \\ \text { Length } & 8.8 \mathrm{mi} \\ \text { Slope } & 46.3 \mathrm{ft} / \mathrm{mi} \\ \text { Elevation } & 1,060 \mathrm{ft} \\ \text { Storage } & 0.13 \text { percent }\end{array}$

Forest Precipitation

A Soil

D Soil

62 percent

37.0 in.

ND

Low-flow characteristics:

$$
\frac{\begin{array}{c}
\text { Discharge } \\
\left(\mathrm{ft}^{3} / \mathrm{s}\right)
\end{array}}{\begin{array}{c}
7-\text { day } \\
\text { 14-day } \\
\text { 30-day }
\end{array}}
$$

Basis of low-flow estimates:

\begin{tabular}{lccc}
\multicolumn{3}{c}{ Recurrence interval } \\
\cline { 1 - 1 } 2-year & 10-year & & 20-yeax \\
0.1 & 0.01 & & 0.01 \\
0.1 & 0.02 & & 0.01 \\
0.2 & 0.03 & & 0.01
\end{tabular}

Correlated with 01609000, Town Creek near Oldtown, Md.

Number of base-flow observations used -. 11

Base-flow observations used, made in 1975-79

Equivalent years of record --
Coefficient of determination $\left(R^{2}\right) \cdots 0.89$

Standard error of estimate (SE) - 53 percent

Minimum observed discharge used in correlation -- $0.12 \mathrm{ft}^{3} / \mathrm{s}$ 
Table 12.--Basin characteristics and low-flow characteristics at partial-record streamflow-gaging stations in Maryland and Delaware--Continued

01613150 Ditch Rum near Hancock, Md.

Location: Lat $39^{\circ} 41^{\prime} 30^{\prime \prime}$, long $78^{\circ} 07^{\prime} 57^{\prime \prime}$, Washington County, at culvert on U.S. Highway 40 , 2.7 mi east of Hancock.

Basin characteristics:

Drainage area
Length
Slope
Elevation
Storage

$\begin{array}{ll}4.80 \mathrm{mi}^{2} \\ 6.5 \mathrm{mi} \\ 47.5 \mathrm{ft} / \mathrm{mi} \\ 16 & \mathrm{ft} \\ 0.32 & \text { percent }\end{array}$

$\begin{array}{lrl}\text { Forest } & 28 & \text { percent } \\ \text { Precipitation } & 37.0 \text { in. } \\ \text { A Soil } & \text { ND } \\ \text { D Soil } & \text { ND }\end{array}$

Low-flow characteristics:

$$
\begin{gathered}
\begin{array}{c}
\text { Discharge } \\
\left(\mathrm{ft}^{3} / \mathrm{s}\right)
\end{array} \\
\begin{array}{c}
7-\text { day } \\
14-\text { day } \\
30-\text { day }
\end{array}
\end{gathered}
$$

Recurrence interval

$\begin{array}{lll}0.1 & 0.02 & 0.01 \\ 0.1 & 0.02 & 0.01 \\ & 0.03 & 0.02\end{array}$

Basis of low-flow estimates:

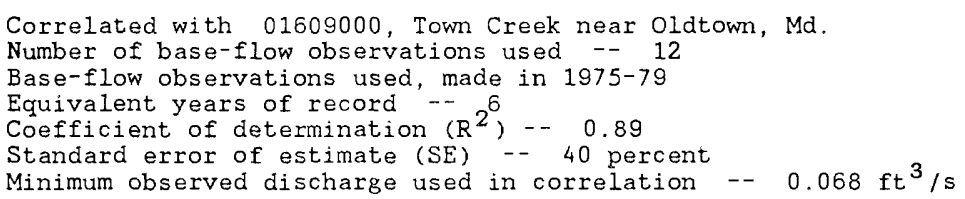

01613540 Lanes Run near Forsythe, Md.

Location: Lat $39^{\circ} 39^{\prime} 50^{\prime \prime}$, long $78^{\circ} 00^{\prime} 08^{\prime \prime}$, Washington County, at bridge on Little Cove Road, $1.2 \mathrm{mi}$ north of Indian Springs.

\begin{tabular}{|c|c|c|}
\hline 2-year & 10 -year & 20 -year \\
\hline $\begin{array}{l}0.4 \\
0.5\end{array}$ & $\begin{array}{l}0.2 \\
0.2\end{array}$ & $\begin{array}{l}0.2 \\
0.2\end{array}$ \\
\hline
\end{tabular}

Basin characteristics:

$\begin{array}{lclcc}\text { Drainage area } & 9.98 \mathrm{mi}^{2} & \text { Forest } & 79 \text { percent } \\ \text { Length } & 5.9 \mathrm{mi} & \text { Precipitation } & 38.0 \mathrm{in} . \\ \text { Slope } & 164 & \mathrm{ft} / \mathrm{mi} & \text { A Soil } & \text { ND } \\ \text { Elevation } & 1,010 \mathrm{ft} & \text { D Soil } & \text { ND } \\ \text { Storage } & 0.06 \mathrm{percent} & & \end{array}$

Low-flow characteristics:

$$
\begin{gathered}
\begin{array}{c}
\text { Discharge } \\
\left(\mathrm{ft}^{3} / \mathrm{s}\right)
\end{array} \\
\begin{array}{c}
7 \text {-day } \\
\text { 14-day } \\
30-\text { day }
\end{array}
\end{gathered}
$$

Basis of low-flow estimates:

Correlated with 01614500, Conococheague Creek at Fa1rview, Md.

Number of base-flow observations used -- 10

Base-flow observations used, made in 1980-82, 1985-86

Equivalent years of record - 20

Coefficient of determination $\left(\mathrm{R}^{2}\right)-0.94$

Standard error of estimate (SE) - 28 percent

Minimum observed discharge used in correlation -- $0.34 \mathrm{ft}^{3} / \mathrm{s}$ 
Table 12.--Basin characteristics and low-flow characteristics at partial-record streamflow-gaging stations in Maryland and Delaware--Continued

01614525 Rockdale Rum at Fairview, Md.

Location: Lat $39^{\circ} 42^{\prime} 07^{\prime \prime}$, long $77^{\circ} 50^{\prime} 45^{\prime \prime}$, Washington County, at bridge on Rockdale Road, 0.7 mi south of Fairview.

Basin characteristics:

Drainage area
Length
Slope
Elevation
Storage

$\begin{array}{ll}9.67 \mathrm{mi}^{2} \\ 5.5 \mathrm{mi} \\ 144 & \mathrm{ft} / \mathrm{mi} \\ 667 & \mathrm{ft} \\ 0.11 & \text { percent }\end{array}$

\begin{tabular}{|c|c|}
\hline $\begin{array}{l}\text { Forest } \\
\text { Precipitation } \\
\text { A Soil } \\
\text { D Soil }\end{array}$ & $\begin{array}{r}20 \\
39.0 \\
\text { ND } \\
\text { ND }\end{array}$ \\
\hline
\end{tabular}

Low-flow characteristics:

Discharge
$\frac{\left(\mathrm{ft}^{3} / \mathrm{s}\right)}{7-\text { day }}$
$\begin{gathered}\text { 14-day } \\ \text { 30-day }\end{gathered}$

\begin{tabular}{lcc}
\multicolumn{3}{c}{ Recurrence interval } \\
\cline { 1 - 1 } 2-year & 10-year & 20-year \\
2.5 & 1.5 & 1.3 \\
2.6 & 1.6 & 1.4 \\
2.8 & 1.8 & 1.6
\end{tabular}

Basis of low-flow estimates:

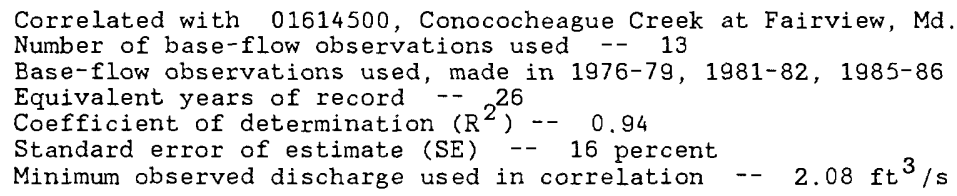

\section{Rush Rum at Troupe Springs, Md.}

Location: Lat $39^{\circ} 40^{\prime} 26^{\prime \prime}$, long $77^{\circ} 47^{\prime} 42^{\prime \prime}$, Washington County, below confluence with Troupe run, 500 ft downstream from bridge on State Highway $63,1.5 \mathrm{mi}$ north of Huyett.

(data formerly published incorrectly, as at 01614575 , Rush Run near Huyett, which is 500 ft upstream)

Basin characteristics:

Drainage area
Length
Slope
Elevation
Storage

$\begin{array}{cl}9.49 \mathrm{mi}^{2} \\ 6.1 \mathrm{mi} \\ 46.8 \mathrm{ft} / \mathrm{mi} \\ 566 & \mathrm{ft} \\ 0.02 & \text { percent }\end{array}$

\begin{tabular}{|c|c|}
\hline $\begin{array}{l}\text { Forest } \\
\text { Precipitation } \\
\text { A Soil } \\
\text { D Soil }\end{array}$ & $\begin{array}{l}1 \text { percent } \\
39.0 \text { in. } \\
\text { ND } \\
\text { ND }\end{array}$ \\
\hline
\end{tabular}

Low-flow characteristics:

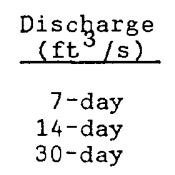

\begin{tabular}{|c|c|c|}
\hline 2-year & 10 -year & 20 -year \\
\hline 2.5 & 1.2 & 0.9 \\
\hline 2.6 & 1.2 & 0.9 \\
\hline 2.8 & 1.4 & 1.1 \\
\hline
\end{tabular}

Basis of low-flow estimates:

Correlated with 01619000, Antiıtam Creek near Waynesboro, Pa.

Number of base-flow observations used -- 8

Base-flow observations used, made in 1976-79, 1981

Equivalent years of record -- $2^{7}$

Coefficient of determination $\left(R^{2}\right) \ldots 0.94$

Standard error of estimate (SE) -- 21 percent

Minimum observed discharge used in correlation -- $1.60 \mathrm{ft}^{3} / \mathrm{s}$ 
Table 12,--Basin characteristics and low-flow characteristics at partial-record streamflow-gaging stations in Maryland and Delaware--Continued

\section{Conococheague Creek Tributary near Huryett, Md.}

Location: Lat $39^{\circ} 37^{\prime} 39^{\prime \prime}$, long $77^{\circ} 48^{\prime} 43^{\prime \prime}$, Washington County, at bridge on light-duty road, 1.9 mi south of Huyett.

Basin characteristics:

$\begin{array}{lc}\text { Drainage area } & 7.94 \mathrm{mi}^{2} \\ \text { Length } & 6.6 \mathrm{mi} \\ \text { Slope } & 41.7 \mathrm{ft} / \mathrm{mi} \\ \text { Elevation } & 533 \quad \mathrm{ft} \\ \text { Storage } & 0.11 \mathrm{percent}\end{array}$

$\begin{array}{lrl}\text { Forest } & 4 & \text { percent } \\ \text { Precipitation } & 39.0 & \text { in. } \\ \text { A Soil } & \text { ND } \\ \text { D Soil } & \text { ND }\end{array}$

Low-flow characteristics:

Discbarge
$(\mathrm{ft} / \mathrm{s})$
$\begin{gathered}7 \text {-day } \\ 14-\text { day } \\ 30-\text { day }\end{gathered}$

\begin{tabular}{|c|c|c|}
\hline 2-year & 10 -year & 20 -year \\
\hline 0.8 & 0.4 & 0.3 \\
\hline 0.9 & 0.4 & 0.4 \\
\hline 1.0 & 0.5 & 0.4 \\
\hline
\end{tabular}

Basis of low-flow estimates:

Correlated with 01614500, Conococheague Creek at Fairview, Md.

Number of base-flow observations used -- 14

Base-flow observations used, made in 1977-79, 1981-82, 1985-86

Equivalent years of record --
Coefficient of determination $\left(\mathrm{R}^{2}\right)--0.89$

Standard error of estimate (SE) -- 28 percent

Minimum observed discharge used in correlation -- $0.56 \mathrm{ft}^{3} / \mathrm{s}$

01617600 Downey Branch near Downville, Md.

Location: Lat $39^{\circ} 32^{\prime} 19^{\prime \prime}$, long $77^{\circ} 49^{\prime} 11^{\prime \prime}$, Washington County, at bridge on Dellinger Road, $1.1 \mathrm{mi}$ southwest of Downsville.

Basin characteristics:

Drainage area
Length
Slope
Elevation
Storage

$\begin{array}{rl}3.00 \mathrm{mi}^{2} \\ 4.0 \mathrm{mi} \\ 35.1 \mathrm{ft} / \mathrm{mi} \\ 473 & \mathrm{ft} \\ 0.03 & \text { percent }\end{array}$

0.03 percent

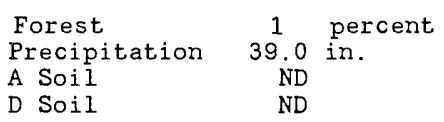

\section{Low-flow characteristics}

\begin{tabular}{|c|c|c|}
\hline 2-year & 10 -year & 20 -year \\
\hline $\begin{array}{l}0.8 \\
0.9 \\
0.9\end{array}$ & $\begin{array}{l}0.3 \\
0.3 \\
0.4\end{array}$ & $\begin{array}{l}0.2 \\
0.3 \\
0.3\end{array}$ \\
\hline
\end{tabular}

Basis of low-flow estimates:

Correlated with 01617800 , Marsh Run at Grimes, Md.

Number of base-flow observations used -- 10

Base-flow observations used, made in 1976-79, 1981-82

Equivalent years of record -- ${ }^{9}$

Coefficient of determination $\left(R^{2}\right)--0.93$

Standard error of estimate (SE) -- 18 percent

Minimum observed discharge used in correlation -- $0.78 \mathrm{ft}^{3} / \mathrm{s}$ 
Table 12.--Basin characteristics and low-flow characteristics at partial-record streamflow-gaging stations in Maryland and Delaware--Continued

\section{Little Antietam Creek at Leitersburg, Md.}

Location: Lat $39^{\circ} 40^{\prime} 57^{\prime \prime}$, long $77^{\circ} 37^{\prime} 44^{\prime \prime}$, Washington County, at bridge on State Highway 62 , $0.8 \mathrm{mi}$ southwest of Leitersburg.

Basin characteristics:

Drainage area
Length
Slope
Elevation
Storage

$\begin{array}{rl}24.5 & \mathrm{mi}^{2} \\ 10.9 & \mathrm{mi} \\ 101 & \mathrm{ft} / \mathrm{mi} \\ 968 & \mathrm{ft} \\ 0.11 & \text { percent }\end{array}$

$\begin{array}{lrr}\text { Forest } & 30 & \text { percent } \\ \text { Precipitation } & 39.5 \text { in. } \\ \text { A Soil } & \text { ND } \\ \text { D Soil } & \text { ND }\end{array}$

0.11 percent

Low-flow characteristics:

$$
\begin{gathered}
\begin{array}{c}
\text { Discharge } \\
\left(\mathrm{ft}^{3} / \mathrm{s}\right)
\end{array} \\
\begin{array}{c}
7-\text { day } \\
\text { 14-day } \\
30-\text { day }
\end{array}
\end{gathered}
$$

$\begin{array}{lccc}2 \text { 2-year } & \text { 10-year } & \text { 20-year } \\ 8.2 & 5.0 & & 4.2 \\ 8.5 & 5.1 & 4.3 \\ 9.0 & 5.5 & & 4.6\end{array}$

Recurrence interval

Basis of low-flow estimates:

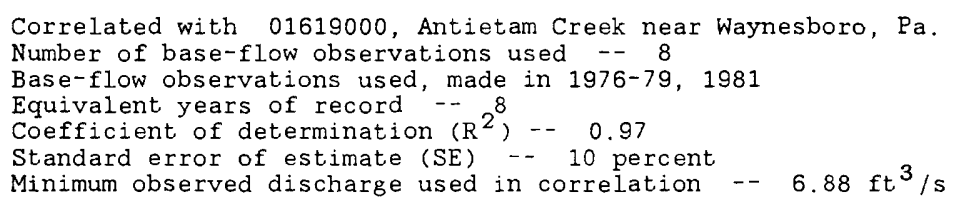

01619325 Beaver Creek at Benevola, Md.

Location: Lat $39^{\circ} 33^{\prime} 04^{\prime \prime}$, long $77^{\circ} 40^{\prime} 55^{\prime \prime}$, Washington County, at bridge on Roxbury Road, at Benevola .

Basin characteristics:

$\begin{array}{lrllc}\text { Drainage area } & 22.9 \mathrm{mi}^{2} & \text { Forest } & 46 & \text { percent } \\ \text { Length } & 13.5 \mathrm{mi} & \text { Precipitation } & 39.0 \text { in. } \\ \text { Slope } & 36.9 \mathrm{ft} / \mathrm{mi} & \text { A Soil } & \text { ND } \\ \text { Elevation } & 870 & \mathrm{ft} & \text { D Soil } & \text { ND } \\ \text { Storage } & 0.09 \mathrm{percent} & & \end{array}$

Low-flow characteristics:

$$
\begin{gathered}
\begin{array}{c}
\text { Discharge } \\
\left(\mathrm{ft}^{3} / \mathrm{s}\right)
\end{array} \\
\begin{array}{l}
7-\text { day } \\
\text { 14-day } \\
30-\text { day }
\end{array}
\end{gathered}
$$

\begin{tabular}{lcc}
\multicolumn{3}{c}{ Recurrence interval } \\
\cline { 1 - 1 } 2-year & 10-year & 20-year \\
15 & 10 & 9.1 \\
17 & 11 & 9.2 \\
11 & 11 & 9.9
\end{tabular}

Basis of low-flow estimates:

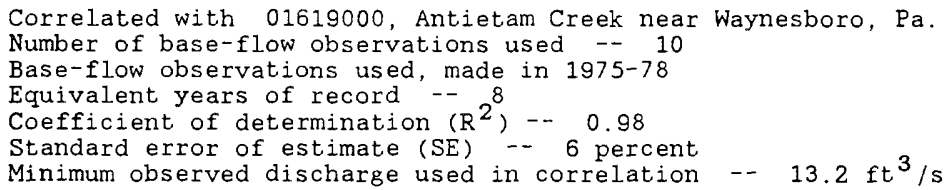


Table 12.--Basin characteristics and low-flow characteristics at partial-record streamflow-gaging stations in Maryland and Delaware--Continued

01619350 Little Beaver Creek at Benevola, Md.

Location: Lat $39^{\circ} 32^{\prime} 48^{\prime \prime}$, long $77^{\circ} 40^{\prime} 39^{\prime \prime}$, Washington County, at bridge on U.S. Highway 40 (Alternate), at Benevola.

Basin characteristics:

$\begin{array}{lc}\text { Drainage area } & 8.70 \mathrm{mi}^{2} \\ \text { Length } & 5.8 \mathrm{mi} \\ \text { Slope } & 86.1 \mathrm{ft} / \mathrm{mi} \\ \text { Elevation } & 794 \mathrm{ft} \\ \text { Storage } & 0.52 \mathrm{percent}\end{array}$

Forest 44 percent

Precipitation $\quad 40.0$ in.

A Soil ND

Storage

0.52 percent

ND

Low-flow characteristics:

$\frac{\begin{array}{l}\text { Discharge } \\ \left(\mathrm{ft}^{3} / \mathrm{s}\right)\end{array}}{\text { 7-day }}$

\begin{tabular}{ccc}
\multicolumn{3}{c}{ Recurrence interval } \\
\cline { 1 - 1 } 2-year & 10-year & 20-year \\
4.4 & 2.7 & 2.3 \\
4.6 & 2.7 & 2.3 \\
4.8 & 2.9 & 2.5
\end{tabular}

Basis of low-flow estimates:

Correlated with 01619000, Antietam Creek near Waynesboro, $\mathrm{Pa}$

Number of base-flow observations used - 10

Base-flow observations used, made in 1975-78

Equivalent years of record -- 8

Coefficient of determination $\left(R^{2}\right)-0.93$

Standard error of estimate (SE) - 16 percent

Minimum observed discharge used in correlation -- $3.27 \mathrm{ft}^{3} / \mathrm{s}$

01619480 Little Antietam Creek at Keedysville, Md.

Location: Lat $39^{\circ} 29^{\prime} 10^{\prime \prime}$, long $77^{\circ} 42^{\prime} 05^{\prime \prime}$, Washington County, at bridge on Koffman Lane, at Keedysville.

Basin characteristics:

Drainage area
Length
Slope
Elevation
Storage

$\begin{array}{rl}24.4 & \mathrm{mi}^{2} \\ 7.2 & \mathrm{mi} \\ 45.6 & \mathrm{ft} / \mathrm{mi} \\ 697 & \mathrm{ft} \\ 0.13 & \text { percent }\end{array}$

$\begin{array}{lr}\text { Forest } & 35 \text { percent } \\ \text { Precipitation } & 39.5 \text { in. } \\ \text { A Soil } & \text { ND } \\ \text { D Soil } & \text { ND }\end{array}$

Low-flow characteristics:

Discharge
$\left(\mathrm{ft}^{3} / \mathrm{s}\right)$
$\begin{gathered}7-\text { day } \\ 14-\text { day } \\ 30-\text { day }\end{gathered}$

\begin{tabular}{|c|c|c|}
\hline 2-year & 10 -year & 20-year \\
\hline $\begin{array}{l}5.0 \\
5.6 \\
6.2\end{array}$ & $\begin{array}{l}1.9 \\
2.2 \\
2.5\end{array}$ & $\begin{array}{l}1.4 \\
1.6 \\
1.9\end{array}$ \\
\hline
\end{tabular}

Basis of low-flow estimates:

Correlated with 01617800, Marsh Run at Grimes, Md.

Number of base-flow observations used -- 18

Base-flow observations used, made in $1964-68,1970,1977-79,1985-86$

Equivalent years of record --
Coefficient of determination $\left(\mathrm{R}^{2}\right)--0.83$

Standard error of estimate (SE) -- 29 percent

Minimum observed discharge used in correlation -- $3.33 \mathrm{ft}^{3} / \mathrm{s}$ 
Table 12.--Basin characteristics and low-flow characteristics at partial-record streamflow-gaging stations in Maryland and Delaware--Continued

01636730 Isreal Creek at Weverton, Md.

Location (Revised): Lat $39^{\circ} 19^{\prime} 45^{\prime \prime}$, long $77^{\circ} 41^{\prime} 03^{\prime \prime}$, Washington County, at bridge on light-duty road, at Weverton.

Basin characteristics:

Drainage area
Length
Slope
Elevation
Storage

$\begin{array}{rl}13.2 & \mathrm{mi}^{2} \\ 8.5 & \mathrm{mi} \\ 50.1 & \mathrm{ft} / \mathrm{mi} \\ 708 & \mathrm{ft} \\ 0.16 & \text { percent }\end{array}$

\begin{tabular}{|c|c|}
\hline Forest & 49 \\
\hline $\begin{array}{l}\text { Precipitation } \\
\text { A Soil. }\end{array}$ & $\begin{array}{r}40.0 \\
\text { ND }\end{array}$ \\
\hline D Soil & ND \\
\hline
\end{tabular}

Low-flow characteristics:

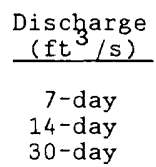

\begin{tabular}{|c|c|c|}
\hline 2-year & 10 -year & 20 -yea \\
\hline $\begin{array}{l}1.1 \\
1.3 \\
1.7\end{array}$ & $\begin{array}{l}0.3 \\
0.4 \\
0.6\end{array}$ & $\begin{array}{l}0.2 \\
0.2 \\
0.4\end{array}$ \\
\hline
\end{tabular}

Basis of low-flow estimates:

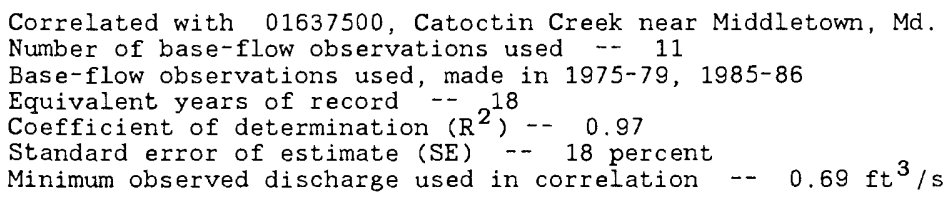

01636850 Little Catoctin Creek near Brumswick, Md.

Location: Lat $39^{\circ} 19^{\prime} 25^{\prime \prime}$, Long $77^{\circ} 35^{\prime} 35^{\prime \prime}$, Frederick County, at bridge on State Highway 464, 1.4 mi northeast of Brunswick.

Basin characteristics:

Drainage area
Length
Slope
Elevation
Storage

$\begin{array}{cl}8.70 \mathrm{mi}^{2} \\ 6.6 \mathrm{mi} \\ 40.4 \mathrm{ft} / \mathrm{mi} \\ 528 & \mathrm{ft} \\ 0.12 & \text { percent }\end{array}$

$\begin{array}{lrr}\text { Forest } & 16 & \text { percent } \\ \text { Precipitation } & 40.5 \mathrm{in} . \\ \text { A Soil } & \text { ND } \\ \text { D Soil } & \text { ND }\end{array}$

Low-flow characteristics:

$$
\begin{gathered}
\begin{array}{c}
\text { Discharge } \\
\text { (ft } 3 / \mathrm{s})
\end{array} \\
\begin{array}{c}
7-\text { day } \\
14-\text { day } \\
30-\text { day }
\end{array}
\end{gathered}
$$

\begin{tabular}{|c|c|c|}
\hline 2-year & 10 -year & 20 -year \\
\hline $\begin{array}{l}0.4 \\
0.4 \\
0.6\end{array}$ & $\begin{array}{l}0.09 \\
0.1 \\
0.2\end{array}$ & $\begin{array}{l}0.05 \\
0.07 \\
0.1\end{array}$ \\
\hline
\end{tabular}

\section{Basis of low-flow estimates:}

\footnotetext{
Correlated with 01637500, Catoctin Creek near Middletown, Md.

Number of base-flow observations used -- 13

Base-flow observations used, made in 1977-83

Equivalent years of record - 18

Coefficient of determination $\left(\mathrm{R}^{2}\right) \cdots 0.97$

Standard error of estimate (SE) - 24 percent

Minimum observed discharge used in correlation -- $0.23 \mathrm{ft}^{3} / \mathrm{s}$
} 
Table 12.--Basin characteristics and low-flow characteristics at partial-record streamflow-gaging stations in Maryland and Delaware--Continued

01636975 Middle Creek at Ellerton, Md.

Location: Lat $39^{\circ} 31^{\prime} 33^{\prime \prime}$, long $77^{\circ} 32^{\prime} 15^{\prime \prime}$, Frederick County, at bridge on Crow Rock Road, 0.4 mi east of E11erton.

Basin characteristics:

$\begin{array}{lrl}\text { Drainage area } & 22.7 \mathrm{mi}^{2} \\ \text { Length } & 11.0 \mathrm{mi} \\ \text { Slope } & 93.3 \mathrm{ft} / \mathrm{mi} \\ \text { Elevation } & 1,280 & \mathrm{ft} \\ \text { Storage } & 0.07 \text { percent }\end{array}$

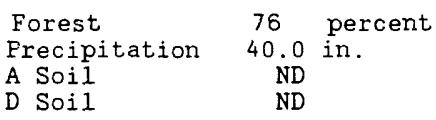

Low-flow characteristics:

Discharge
$\frac{\left.\mathrm{ft}^{3} / \mathrm{s}\right)}{7-\text { day }}$
$\begin{aligned} & \text { 14-day } \\ & 30-\text { day }\end{aligned}$

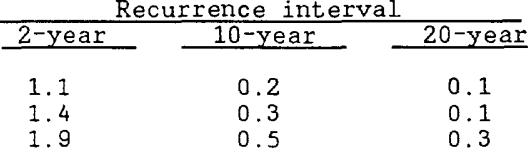

Basis of low-flow estimates:

Correlated with 01637500 , Catoctin Creek near Middletown, Md.

Number of base-flow observations used -- 13

Base-flow observations used, made in 1977-82

Equivalent years of record --
Coefficient of determination $\left(\mathrm{R}^{2}\right)--0.94$

Standard error of estimate (SE) -- 31 percent

Minimum observed discharge used in correlation -- $1.05 \mathrm{ft}^{3} / \mathrm{s}$

01638600 Tuscarora Creek at Tuscarora, Md.

Location: Lat $39^{\circ} 15^{\prime} 06^{\prime \prime}$, long $77^{\circ} 28^{\prime} 49^{\prime \prime}$, Frederick County, at bridge on Water Flace Road, 0.7 mi southwest of Tuscarora.

Basin characteristics:

Drainage area
Length
Slope
Elevation
Storage

$\begin{array}{rl}20.3 & \mathrm{mi}^{2} \\ 11.9 & \mathrm{mi} \\ 22.0 & \mathrm{ft} / \mathrm{mi} \\ 382 & \mathrm{ft} \\ 0.11 & \text { percent }\end{array}$

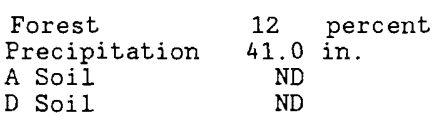

Low-flow characteristics:

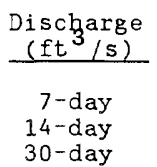

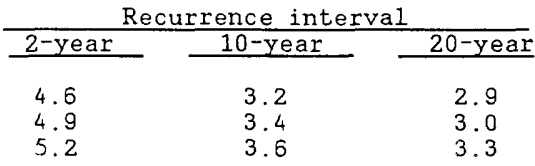

Basis of low-flow estimates:

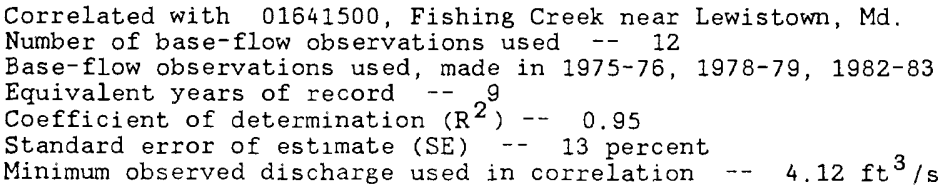


Table 12.--Basin characteristics and low-flow characteristics at partial-record streamflow-gaging stations in Maryland and Delaware--Continued

01639325 Friends Creek near Fmmitsburg, Md.

Location: Lat $39^{\circ} 43^{\prime} 03^{\prime \prime}$, long $77^{\circ} 23^{\prime} 35^{\prime \prime}$, Frederick County, at concrete ford on Hornets Nest Road, $3.5 \mathrm{mi}$ northwest of Emmitsburg.

Basin characteristics:

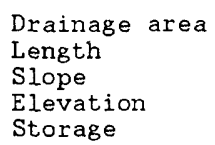

$\begin{array}{rl}12.2 & \mathrm{mi}^{2} \\ 6.9 & \mathrm{mi} \\ 106 & \mathrm{ft} / \mathrm{mi} \\ 1,130 & \mathrm{ft} \\ 0.06 & \text { percent }\end{array}$

$\begin{array}{lrl}\text { Forest } & 65 & \text { percent } \\ \text { Precipitation } & 39.0 \text { in. } \\ \text { A Soil } & \text { ND } \\ \text { D Soil } & \text { ND }\end{array}$

Low-flow characteristics

$$
\begin{gathered}
\begin{array}{c}
\text { Discharge } \\
\left(\mathrm{ft}^{3} / \mathrm{s}\right)
\end{array} \\
\begin{array}{c}
7-\mathrm{day} \\
\text { 14-day } \\
30-\mathrm{day}
\end{array}
\end{gathered}
$$

\begin{tabular}{|c|c|c|}
\hline 2-year & 10 -year & 20 -year \\
\hline 0.3 & 0.07 & 0.03 \\
\hline 0.4 & 0.08 & 0.04 \\
\hline 0.4 & 0.1 & 0.08 \\
\hline
\end{tabular}

Basis of low-flow estimates:

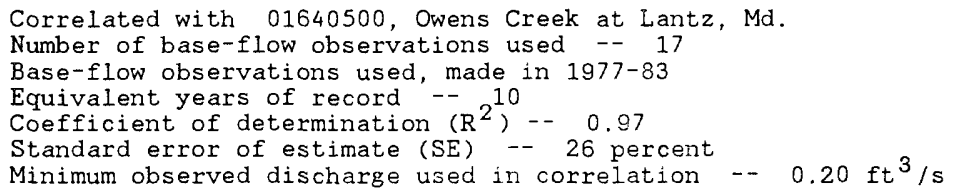

01639400 Big Pipe Creek at Bachman Mills, Md.

Location: Lat $39^{\circ} 39^{\prime} 39^{\prime \prime}$, long $76^{\circ} 56^{\prime} 54^{\prime \prime}$, Carroll County, at bridge on State Highway 496, at Bachman Milis.

Basin characteristics:

Drainage area
Length
Slope
Elevation
Storage

$\begin{array}{rl}9.39 \mathrm{mi}^{2} \\ 4.4 \mathrm{mi} \\ 48.8 \mathrm{ft} / \mathrm{mi} \\ 817 & \mathrm{ft} \\ 0.10 & \text { percent }\end{array}$

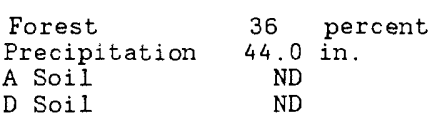

Low-flow characteristics:

$$
\begin{gathered}
\begin{array}{c}
\text { Discharge } \\
\left(\mathrm{ft}^{3} / \mathrm{s}\right)
\end{array} \\
\begin{array}{c}
7-\text { day } \\
14-\text { day } \\
30-\text { day }
\end{array}
\end{gathered}
$$

Basis of low-flow estimates:

\begin{tabular}{lcc}
\multicolumn{3}{c}{ Recurrence interval } \\
\cline { 1 - 1 } 2-year & 10-year & 20-year \\
4.1 & 2.4 & 2.0 \\
4.3 & 2.5 & 2.1 \\
4.5 & 2.8 & 2.4
\end{tabular}

\footnotetext{
Correlated with 01582000 , Little Falls at Blue Mount. Md.

Number of base-flow observations used -- 12

Base-flow observations used, made in 1956-59, 1961-62, 1966

Equivalent years of record -- 19

Coefficient of determination $\left(\mathrm{R}^{2}\right)-0.94$

Standard error of estimate (SE) -- 16 percent

Minimum observed discharge used in correlation -- $1.28 \mathrm{ft}^{3} / \mathrm{s}$
} 
Table 12.--Basin characteristics and low-flow characteristics at partial-record streamflow-gaging stations in Maryland and Delaware--Continued

01639420 Deep Rum at Union Mills, Md.

Location: Lat $39^{\circ} 40^{\prime} 08^{\prime \prime}$, long $77^{\circ} 00^{\prime} 41^{\prime \prime}$, Carroll County, at bridge on county road, $0.7 \mathrm{mi}$ east of Union Mi11s.

Basin characteristics:

Drainage area
Length
Slope
Elevation
Storage

$\begin{array}{cl}5.46 \mathrm{mi}^{2} \\ 4.8 \mathrm{mi} \\ 70.4 \mathrm{ft} / \mathrm{mi} \\ 796 & \mathrm{ft} \\ 0.04 & \text { percent }\end{array}$

\begin{tabular}{|c|c|}
\hline $\begin{array}{l}\text { Forest } \\
\text { Precipitation } \\
\text { A Soil } \\
\text { D Soil }\end{array}$ & $\begin{array}{l}42 \text { percent } \\
44.0 \text { in. } \\
\text { ND } \\
\text { ND }\end{array}$ \\
\hline
\end{tabular}

Low-flow characteristics:

$\frac{\text { Discharge }}{(\mathrm{ft} / \mathrm{s})}$

\begin{tabular}{lcc}
\multicolumn{3}{c}{ Recurrence interval } \\
\cline { 1 - 1 } 2-year & $\frac{10 \text {-year }}{20 \text {-year }}$ & 20 \\
0.7 & 0.2 & 0.1 \\
0.8 & 0.2 & 0.1 \\
0.9 & 0.3 & 0.2
\end{tabular}

Basis of low-flow estimates:

Correlated with 01583500, Western Run at Western Run, Md.

Number of base-flow observations used -- 10

Base-flow observations used, made in 1975-79

Equivalent years of record -- 13

Coefficient of determination $\left(R^{2}\right)-0.96$

Standard error of estimate (SE) - 23 percent

Minimum observed discharge used in correlation -- $0.48 \mathrm{ft}^{3} / \mathrm{s}$

01639470 Meadow Branch near Uniontown, Md.

Location: Lat $39^{\circ} 36^{\prime} 32^{\prime \prime}$, long $77^{\circ} 06^{\prime} 52^{\prime \prime}$, Carroll County, at bridge on State Highway 84 , 1.1 mi north of Uniontown.

Basin characteristics:

Drainage area
Length
Slope
Elevation
Storage

$\begin{array}{rl}12.6 & \mathrm{mi}^{2} \\ 7.9 & \mathrm{mi} \\ 34.6 & \mathrm{ft} / \mathrm{mi} \\ 616 & \mathrm{ft} \\ 0.05 & \text { percent }\end{array}$

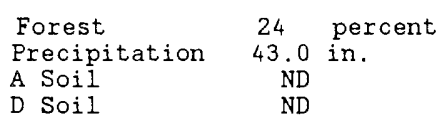

Low-flow characteristics:

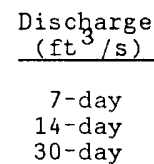

Basis of low-flow estimates:

Correlated with 01642500 , Linganore Creek near Frederick, Md.

Number of base-flow observations used -- 10

Base-flow observations used, made in 1956-59, 1961-63

Equivalent years of record -- 16

Coefficient of determination $\left(\mathrm{R}^{2}\right) \cdots 0.96$

Standard error of estimate (SE) -- 12 percent

Minimum observed discharge used in correlation -- $1.70 \mathrm{ft}^{3} / \mathrm{s}$ 
Table 12.--Basin characteristics and low-flow characteristics at partial-record streamflow-gaging stations in Maryland and Delaware--Continued

01640100 Wolfpit Branch at Linmood, Md.

Location: Lat $39^{\circ} 33^{\prime} 57^{\prime \prime}$, long $77^{\circ} 08^{\prime} 44^{\prime \prime}$, Carroll County, at bridge on State Highway $75,0.2 \mathrm{mi}$ northwest of Linwood.

Basin characteristics:

$\begin{array}{lc}\text { Drainage area } & 2.01 \mathrm{mi}^{2} \\ \text { Length } & 2.3 \mathrm{mi} \\ \text { Slope } & 44.6 \mathrm{ft} / \mathrm{mi} \\ \text { Elevation } & 503 \mathrm{ft} \\ \text { Storage } & 0.04 \text { percent }\end{array}$

$\begin{array}{lcl}\text { Forest } & 18 & \text { percent } \\ \text { Precipitation } & 43.5 \text { in. } \\ \text { A Soil } & \text { ND } \\ \text { D Soil } & \text { ND }\end{array}$

Low-flow characteristics:

$\frac{\text { Discharge }}{\left(\mathrm{ft}^{3} / \mathrm{s}\right)}$

\begin{tabular}{|c|c|c|}
\hline \multirow{2}{*}{\multicolumn{3}{|c|}{ Recurrence interval }} \\
\hline 2-year & & 20 -year \\
\hline 0.9 & 0.5 & 0.4 \\
\hline $\begin{array}{l}0.9 \\
0.9\end{array}$ & $\begin{array}{l}0.5 \\
0.6\end{array}$ & $\begin{array}{l}0.4 \\
0.5\end{array}$ \\
\hline
\end{tabular}

Basis of low-flow estimates:

Correlated with 01583500, Western Run at Western Run, Md.

Number of base-flow observations used -- 12

Base-flow observations used, made in 1956-59, 1961-63, 1966

Equivalent years of record -- 10

Coefficient of determination $\left(\mathrm{R}^{2}\right)--0.87$

Standard error of estimate (SE) -- 17 percent

Minimum observed discharge used in correlation -- $0.43 \mathrm{ft}^{3} / \mathrm{s}$

01640160 Beaver Dam Creek near Union Bridge, Md.

Location: "Lat $39^{\circ} 34^{\prime} 08^{\prime \prime}$, long $77^{\circ} 12 ' 52^{\prime \prime}$, Frederick County, at bridge on Good Intent Road, 1.9 mi west of Union Bridge.

Basin characteristics:

Drainage area
Length
Slope
Elevation
Storage

$\begin{array}{cl}7.04 \mathrm{mi}^{2} \\ 5.4 \mathrm{mi} \\ 30.7 \mathrm{ft} / \mathrm{mi} \\ 538 & \mathrm{ft} \\ 0.09 & \text { percent }\end{array}$

Forest Precipitation

A Soil

26 percent

D Soil

43.0 in.

ND

Low-flow characteristics:

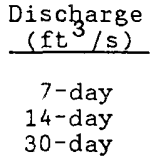

Recurrence interval

$\begin{array}{cc}\frac{10 \text {-year }}{0.5} & \text { 20-year } \\ 0.6 & 0.4 \\ 0.7 & 0.4 \\ & 0.5\end{array}$

Basis of low-flow estimates:

Correlated with 01583500, Western Run at Western Run, Md.

Number of base-flow observations used -- 13

Base-flow observations used, made in 1977-81

Equivalent years of record --
Coefficient of determination $\left(R^{2}\right)--0.96$

Standard error of estimate (SE) -- 14 percent

Minimum observed discharge used in correlation -- $0.97 \mathrm{ft}^{3} / \mathrm{s}$

* Revised 
Table 12.--Basin characteristics and low-flow characteristics at partial-record streamflow-gaging stations in Maryland and Delaware--Continued

01640650 Little Owens Creek near Thurmont, Md.

Location: Lat $39^{\circ} 38^{\prime} 58^{\prime \prime}$, long $77^{\circ} 23^{\prime} 11^{\prime \prime}$, Frederick County, at bridge on Old Lime Kiln Road, $2.0 \mathrm{mi}$ northeast of Thurmont.

Basin characteristics:

$\begin{array}{lcllc}\text { Drainage area } & 6.16 \mathrm{mi}^{2} & \text { Forest } & 75 \text { percent } \\ \text { Length } & 5.1 \mathrm{mi} & \text { Precipitation } & 41.5 \text { in. } \\ \text { Slope } & 175 \mathrm{ft} / \mathrm{mi} & \text { A Soil } & \text { ND } \\ \text { Elevation } & 1,020 \mathrm{ft} & \text { D Soil } & \text { ND } \\ \text { Storage } & 0.39 \text { percent } & & \end{array}$

Low-flow characteristics:

Discharge
$\left(\mathrm{ft}^{3} / \mathrm{s}\right)$
$\begin{gathered}7-\text { day } \\ 14-\text { day } \\ 30-\text { day }\end{gathered}$

\begin{tabular}{|c|c|c|}
\hline 2-year & 10 -year & 20 -year \\
\hline 0.6 & 0.3 & 0.3 \\
\hline 0.7 & 0.4 & 0.3 \\
\hline 0.8 & 0.4 & 0.3 \\
\hline
\end{tabular}

Basis of low-flow estimates:

Correlated with 01641500, Fishing Creek near Lewistown, Md.

Number of base-flow observations used -- 11

Base-flow observations used, made in 1974-79

Equivalent years of record --
Coefficient of determination $\left(\mathrm{R}^{2}\right)--0.97$

Standard error of estimate (SE) - 20 percent

Minimum observed discharge used in correlation -- $0.70 \mathrm{ft}^{3} / \mathrm{s}$

01640720 Beaver Branch at Rocky Ridge, Md.

Location: Lat $39^{\circ} 36^{\prime} 20^{\prime \prime}$, long $77^{\circ} 19^{\prime} 50^{\prime \prime}$, Frederick County, at bridge on State Highway $77,0.6 \mathrm{mi}$ west of Rocky Ridge.

Basin characteristics:

Drainage area
Length
Slope
Elevation
Storage

$\begin{array}{ll}6.53 \mathrm{mi}^{2} \\ 7.3 \mathrm{mi} \\ 80.2 \mathrm{ft} / \mathrm{mi} \\ 561 & \mathrm{ft} \\ 0.21 & \text { percent }\end{array}$

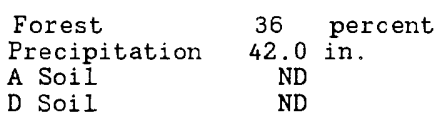

Low-flow characteristics:

$$
\begin{gathered}
\begin{array}{c}
\text { Discharge } \\
\text { (ft } / \mathrm{s})
\end{array} \\
\begin{array}{r}
7 \text {-day } \\
14-\text { day } \\
30-\text { day }
\end{array}
\end{gathered}
$$

\begin{tabular}{|c|c|c|}
\hline 2-year & 10 -year & 20 -year \\
\hline 0.0 & 0.0 & 0.0 \\
\hline 0.0 & 0.0 & 0.0 \\
\hline 0.0 & 0.0 & 0.0 \\
\hline
\end{tabular}

Basis of low-flow estimates:

Correlated with 01640500 , Owens Creek near Lantz, Md.

Number of base-flow observations used -- 12

Base-flow observations used, made in 1977-82

Equivalent years of record -- 12

Coefficient of determination $\left(\mathrm{R}^{2}\right) \cdots 0.98$

Standard error of estimate (SE) -- 18 percent

Minimum observed discharge used in correlation - - $0.0 \mathrm{ft}^{3} / \mathrm{s}$ (5 observations)

Remarks. Observations of zero flow were not used in regression analysis. 
Table 12.--Basin characteristics and low-flow characteristics at partial-record streamflow-gaging stations in Maryland and Delaware--Continued

01640965 Hunting Creek near Forville, Md.

Location: Lat $39^{\circ} 37^{\prime} 10^{\prime \prime}$, long $77^{\circ} 28^{\prime} 00^{\prime \prime}$, Frederick County, at culvert on park road in Cunningham Falls State Park, $2.9 \mathrm{mi}$ west of Thurmont.

Basin characteristics:

Drainage area
Length
Slope
Elevation
Storage

$\begin{array}{ll}2.14 \mathrm{mi}^{2} \\ 2.2 \mathrm{mi} \\ 360 & \mathrm{ft} / \mathrm{m} 1 \\ 1,520 & \mathrm{ft} \\ 0.07 & \text { percent }\end{array}$

$\begin{array}{lrl}\text { Forest } & 94 & \text { percent } \\ \text { Precipitation } & 41.5 \text { in. } \\ \text { A Soil } & \text { ND } \\ \text { D Soil } & \text { ND }\end{array}$

Low-flow characteristics:

$\frac{\begin{array}{l}\text { Discharge } \\ \left(\mathrm{ft}^{3} / \mathrm{s}\right)\end{array}}{\begin{array}{l}7-\text { day } \\ 14-\text { day } \\ 30-\text { day }\end{array}}$

\begin{tabular}{lccc}
\multicolumn{3}{c}{ Recurrence interval } \\
\cline { 1 - 1 } 2-year & 10-year & 20-year \\
0.08 & 0.02 & & 0.01 \\
0.1 & 0.02 & & 0.01 \\
0.1 & 0.03 & & 0.01
\end{tabular}

Basis of low-flow estimates:

Correlated with 01637500 , Catoctin Creek near Middletown, Md.

Number of base-flow observations used -- 25 (daily-flow values)

Base-flow observations used, made in 1981-84 (continuous-record station)

Equivalent years of record -- 12

Coefficient of determination $\left(R^{2}\right)--0.95$

Standard error of estimate (SE) -- 37 percent

Minimum observed discharge used in correlation -- $0.04 \mathrm{ft}^{3} / \mathrm{s}$

01642450 Bens Branch near New Market, Md.

Location: Lat $39^{\circ} 24^{\prime} 58^{\prime \prime}$, long $77^{\circ} 16^{\prime} 45^{\prime \prime}$, Frederick County, at ford on light duty road, $2.3 \mathrm{mi}$ north of New Market.

Basin characteristics:

Drainage area
Length
Slope
Elevation
Storage

$$
\begin{array}{rl}
11.8 & \mathrm{mi}^{2} \\
8.0 & \mathrm{mi} \\
45.9 & \mathrm{ft} / \mathrm{mi} \\
534 & \mathrm{ft} \\
0.10 & \text { percent }
\end{array}
$$

$\begin{array}{lr}\text { Forest } & 30 \\ \text { Precipitation } & 42.0 \text { in. } \\ \text { A Soil } & \text { ND } \\ \text { D Soil } & \text { ND }\end{array}$

Low-flow characteristics:

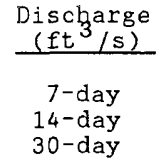

\begin{tabular}{l}
\hline -year \\
\hline 3.2 \\
3.3 \\
3.5
\end{tabular}

Recurrence interval

$\begin{array}{cc}10 \text {-year } & \text { 20-year } \\ 1.3 & 1.0 \\ 1.5 & 1.2 \\ 1.9 & 1.6\end{array}$

Basis of low-flow estimates:

Correlated with 01591000, Patuxent River near Unity, Md.

Number of base-flow observations used -- 16

Base-flow observations used, made in 1975-82

Equivalent years of record -
Coefficient of determination $\left(\mathrm{R}^{2}\right)-0.90$

Standard error of estimate (SE) -- 21 percent

Minimum observed discharge used in correlation -- $2.30 \mathrm{ft}^{3} / \mathrm{s}$ 
Table 12.--Basin characteristics and low-flow characteristics at partial-record streamflow-gaging stations in Maryland and Delaware--Continued

01643125 Ballenger Creek near Lime Kiln, Md.

Location: Lat $39^{\circ} 21^{\prime} 52^{\prime \prime}$, Long $77^{\circ} 25^{\prime} 01^{\prime \prime}$, Frederick County, at bridge on State Highway 85 , 1.2 mi northeast of Lime $\mathrm{Kiln}$.

Basin characteristics:

Drainage area
Length
Slope
Elevation
Storage

$\begin{array}{rl}20.2 & \mathrm{mi}^{2} \\ 9.9 & \mathrm{mi} \\ 32.5 & \mathrm{ft} / \mathrm{mi} \\ 435 & \mathrm{ft} \\ 0.10 & \text { percent }\end{array}$

Forest

Storage

0.10 percent

A Soil

D Soil

24 percent
41.0 in.
ND
ND

Low-flow characteristics:

$\begin{aligned} & \text { Discharge } \\ & \left(\mathrm{ft}^{3} / \mathrm{s}\right)\end{aligned}$
$\begin{gathered}7-\text { day } \\ 14-\text { day } \\ 30-\text { day }\end{gathered}$

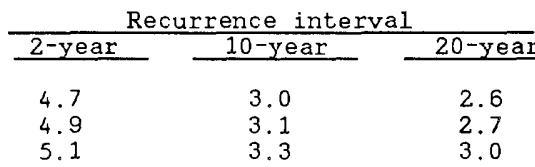

Basis of low-flow estimates:

Correlated with 01641500 , Fishing Creek near Lewistown, Md.

Number of base-flow observations used -- 16

Base-flow observations used, made in 1977-83

Equivalent years of record -- 7

Coefficient of determination $\left(\mathrm{R}^{2}\right) \ldots 0.81$

Standard error of estimate (SE) -- 27 percent

Minimum observed discharge used in correlation -- $3.59 \mathrm{ft}^{3} / \mathrm{s}$

01643400 Little Bennett Creek at Hyattstown, Md.

Location: Lat $39^{\circ} 16^{\prime} 46^{\prime \prime}$, long $77^{\circ} 18^{\prime} 54^{\prime \prime}$, Montgomery County, at bridge on State Highway $355^{\prime}$ at Hyattstown.

Basin characteristics:

Drainage area
Length
Slope
Elevation
Storage

$$
\begin{array}{rl}
12.8 & \mathrm{mi}^{2} \\
7.0 & \mathrm{mi} \\
52.1 & \mathrm{ft} / \mathrm{mi} \\
587 & \mathrm{ft} \\
0.05 & \text { percent }
\end{array}
$$

\begin{tabular}{|c|c|c|}
\hline 2-year & 10 -year & 20 -year \\
\hline $\begin{array}{l}2.4 \\
2.6 \\
3.1\end{array}$ & $\begin{array}{l}0.6 \\
0.6 \\
0.9\end{array}$ & $\begin{array}{l}0.3 \\
0.4 \\
0.6\end{array}$ \\
\hline
\end{tabular}

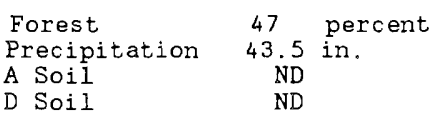

Low-flow characteristics:

$$
\frac{\begin{array}{c}
\text { Discharge } \\
\left(\mathrm{ft}^{3} / \mathrm{s}\right)
\end{array}}{\begin{array}{c}
7-\text { day } \\
14-\text { day } \\
30-\text { day }
\end{array}}
$$

Basis of low-flow estimates:

Correlated with 01645000, Seneca Creek at Dawsonville, Md.

Number of base-flow observations used -- 15

Base-flow observations used, made in 1968-69, 1975-79

Equivalent years of record --
Coefficient of determination $\left(\mathrm{R}^{2}\right)-0.94$

Standard error of estimate (SE) - - 20 percent

Minimum observed discharge used in correlation -- $1.38 \mathrm{ft}^{3} / \mathrm{s}$ 
Table 12.--Basin characteristics and low-flow characteristics at partial-record streamflow-gaging stations in Maryland and Delaware--Continued

01643615 Broad Run at Elmer, Md.

Location: Lat $39^{\circ} 07^{\prime} 22^{\prime \prime}$, long $77^{\circ} 28^{\prime} 52^{\prime \prime}$, Montgomery County, at bridge on River Road, 1.2 mi south of Elmer.

Basin characteristics:

Drainage area
Length
Slope
Elevation
Storage

$\begin{array}{rl}14.2 & \mathrm{mi}^{2} \\ 7.8 & \mathrm{mi} \\ 22.9 & \mathrm{ft} / \mathrm{mi} \\ 342 & \mathrm{ft} \\ 0.28 & \text { percent }\end{array}$

Forest 33 percent

Precipitation 41.5 in.

A Soil ND

Storage

0.28 percent

ND

Low-flow characteristics:

Discharge
$\frac{\left(\mathrm{ft}^{3} / \mathrm{s}\right)}{7-\text { day }}$
$\begin{aligned} & 14-\text { day } \\ & 30-\text { day }\end{aligned}$

\begin{tabular}{|c|c|c|}
\hline 2-year & 10 -year & 20-year \\
\hline 0.3 & 0.05 & 0.02 \\
\hline 0.3 & 0.06 & 0.03 \\
\hline 0.4 & 0.1 & 0.06 \\
\hline
\end{tabular}

Basis of low-flow estimates:

Correlated with 01637500 , Catoctin Creek at Middletown, Md.

Number of base-flow observations used -- 16

Base-flow observations used, made in 1975-82

Equivalent years of record -- 14

Coefficient of determination $\left(\mathrm{R}^{2}\right)-0.94$

Standard error of estimate (SE) -- 35 percent

Minimum observed discharge used in correlation -- $0.25 \mathrm{ft}^{3} / \mathrm{s}$

01644480 Goshen Branch at Goshen, Md.

Location: Lat $39^{\circ} 12^{\prime} 10^{\prime \prime}$, long $77^{\circ} 12^{\prime} 06^{\prime \prime}$, Montgomery County, 0.1 mi upstream from mouth, 0.7 mi west of Goshen.

Basin characteristics:

Drainage area
Length
Slope
Elevation
Storage

$\begin{array}{ll}7.63 \mathrm{mi}^{2} \\ 4.5 \mathrm{mi} \\ 44.6 \mathrm{ft} / \mathrm{mi} \\ 513 & \text { ft } \\ 0.10 & \text { percent }\end{array}$

\begin{tabular}{|c|c|}
\hline $\begin{array}{l}\text { Forest } \\
\text { Precipitation } \\
\text { A Soil } \\
\text { D Soil }\end{array}$ & $\begin{array}{r}38 \\
46.0 \\
\text { ND } \\
\text { ND }\end{array}$ \\
\hline
\end{tabular}

Low-flow characteristics:

$$
\begin{gathered}
\begin{array}{c}
\text { Discharge } \\
\left(\mathrm{ft}^{3} / \mathrm{s}\right)
\end{array} \\
\begin{array}{c}
7-\text { day } \\
\text { 14-day } \\
30-\text { day }
\end{array}
\end{gathered}
$$

\section{Basis of low-flow estimates:}

Correlated with 01645000, Seneca Creek at Dawsonville, Md.

Number of base-flow observations used -- 9

Base-flow observations used, made in 1975-79

Equivalent years of record -- 25

Coefficient of determination $\left(\mathrm{R}^{2}\right)--0.95$

Standard error of estimate (SE) - 15 percent

Minimum observed discharge used in correlation -- $1.65 \mathrm{ft}^{3} / \mathrm{s}$ 
Table 12.--Basin characteristics and low-flow characteristics at partial-record streamflow-gaging stations in Maryland and Delaware--Continued

01644500 Great Seneca Creek near Gaithersburg, Md.

Location: Lat $39^{\circ} 10^{\prime} 01^{\prime \prime}$, long $77^{\circ} 13^{\prime} 37^{\prime \prime}$, Montgomery County, 0.1 mi downstream from Whetstone Run, 2 mi northwest of Gaithersburg.

Basin characteristics:

$\begin{array}{lrl}\text { Drainage area } & 41.0 \mathrm{mi}^{2} \\ \text { Length } & 14.7 \mathrm{mi} \\ \text { Slope } & 7.6 \mathrm{ft} / \mathrm{mi} \\ \text { Elevation } & 527 & \mathrm{ft} \\ \text { Storage } & 0.05 \text { percent }\end{array}$

Forest 25 percent

Precipitation 42.0 in

Storage

0.05 percent

A Soil ND

$\begin{array}{ll}\text { A Soil Noil N } & \text { ND }\end{array}$

Low-flow characteristics:

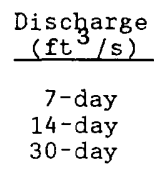

\begin{tabular}{lcc}
\multicolumn{3}{c}{ Recurrence interval } \\
\cline { 1 - 2 } 2-year & 10-year & 20-year \\
10 & 3.2 & \\
11 & 3.6 & 2.1 \\
14 & 4.8 & 2.4 \\
& & 3.2
\end{tabular}

Basis of low-flow estimates:

Correlated with 01592000, Patuxent River near Burtonsville, Md.

Number of base-flow observations used -- 23 (daily-flow values)

Base-flow observations used, made in 1926-30 (continuous-record station)

Equivalent years of record -- 13

Coefficient of determination $\left(R^{2}\right)--0.97$

Standard error of estimate (SE) - 17 percent

Minimum observed discharge used in correlation -- $1.9 \mathrm{ft}^{3} / \mathrm{s}$

01647620 Rock Creek at Redland, Md.

Location: Lat $39^{\circ} 08^{\prime} 14^{\prime \prime}$, long $77^{\circ} 07^{\prime} 46^{\prime \prime}$, Montgomery County, at bridge on State Highway 115 , 1.0 mi southeast of Redland.

Basin characteristics:

$\begin{array}{lclrr}\text { Drainage area } & 7.45 \mathrm{mi}^{2} & \text { Forest } & 25 \text { percent } \\ \text { Length } & 5.8 \mathrm{mi} & \text { Precipitation } & 42.5 \mathrm{in} . \\ \text { Slope } & 37.6 \mathrm{ft} / \mathrm{mi} & \text { A Soil } & \text { ND } \\ \text { Elevation } & 492 & \text { Dt } & \text { Doil } & \text { ND } \\ \text { Storage } & 0.20 \text { percent } & & \end{array}$

Low-flow characteristics:

\begin{tabular}{cccc}
$\begin{array}{c}\text { Discharge } \\
\left(\mathrm{ft}^{3} / \mathrm{s}\right)\end{array}$ & \multicolumn{3}{c}{ Recurrence interval } \\
\cline { 2 - 2 } 7-day & 1.8 & 2-year & 20-year \\
14-day & 1.8 & 0.6 & 0.4 \\
30-day & 2.0 & 0.7 & 0.5
\end{tabular}

\section{Basis of low-flow estimates:}

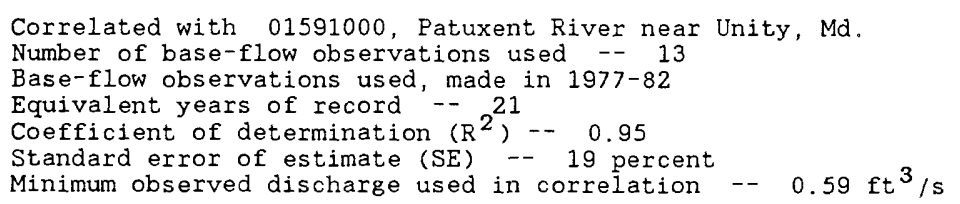


Table 12.--Basin characteristics and low-flow characteristics at partial-record streamflow-gaging stations in Maryland and Delaware--Continued

01650050 Northwest Branch Anacostia River at Korwood, Md.

Location: Lat $39^{\circ} 07^{\prime} 36^{\prime \prime}$, long $77^{\circ} 01^{\prime} 15^{\prime \prime}$, Montgomery County, 20 ft downstream from bridge on Ednor Road, $0.4 \mathrm{mi}$ east of Norwood.

Basin characteristics:

Drainage area
Length
Slope
Elevation
Storage

$\begin{array}{ll}2.45 \mathrm{mi}^{2} \\ 2.1 \mathrm{mi} \\ 42.2 \mathrm{ft} / \mathrm{mi} \\ 455 & \mathrm{ft} \\ 0.26 & \text { percent }\end{array}$

$\begin{array}{lr}\text { Forest } & 33 \text { percent } \\ \text { Precipitation } & 43.0 \text { in. } \\ \text { A Soil } & \text { ND } \\ \text { D Soil } & \text { ND }\end{array}$

Low-flow characteristics:

$\frac{\begin{array}{l}\text { Discharge } \\ \left(\mathrm{ft}^{3} / \mathrm{s}\right)\end{array}}{\begin{array}{c}7-\text { day } \\ \text { 14-day } \\ 30-\text { day }\end{array}}$

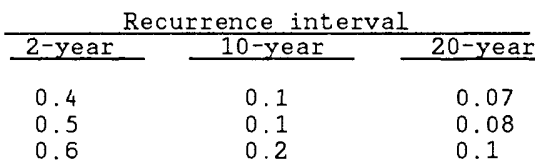

Basis of low-flow estimates:

Correlated with 01650500, Northwest Branch Anacostia River near Colesville, Md.

Number of base-flow observations used -- 25 (daily-flow values)

Base-flow observations used, made in 1967-74 (continuous-record station)

Equivalent years of record -- 8

Coefficient of determination $\left(\mathrm{R}^{2}\right)--0.93$

Standard error of estimate (SE) -- 18 percent

Minimum observed discharge used in correlation -- $0.14 \mathrm{ft}^{3} / \mathrm{s}$

01660740 Port Tobacco Creek near Marshalls Corner, Md.

Location: Lat $38^{\circ} 32^{\prime} 34^{\prime \prime}$, long $77^{\circ} 01^{\prime} 04^{\prime \prime}$, Charles County, at bridge on State Highway 225 , 1.4 mi southeast of Marshalls Corner.

Basin characteristics:

$\begin{array}{lrl}\text { Drainage area } & 15.8 \mathrm{mi}^{2} \\ \text { Length } & 8.9 \mathrm{mi} \\ \text { Slope } & 21.1 \mathrm{ft} / \mathrm{mi} \\ \text { Elevation } & 167 & \mathrm{ft} \\ \text { Storage } & 2.26 \text { percent }\end{array}$

$\begin{array}{lr}\text { Forest } & 68 \\ \text { Precipitation } & 44.0 \text { in. } \\ \text { A Soil } & \text { ND } \\ \text { D Soil } & \text { ND }\end{array}$

Low-flow characteristics:

$$
\frac{\begin{array}{c}
\text { Discharge } \\
\left(\mathrm{ft}^{3} / \mathrm{s}\right)
\end{array}}{\begin{array}{c}
7-\text { day } \\
\text { 14-day } \\
30-\text { day }
\end{array}}
$$

\begin{tabular}{cccc}
\multicolumn{3}{c}{ Recurrence interval } \\
\cline { 1 - 1 } 2-year & 10-year & & \\
0.9 & 0.0 & & 0.0 \\
1.2 & 0.0 & & 0.0 \\
1.7 & 0.0 & & 0.0
\end{tabular}

Basis of low-flow estimates:

Correlated with 01661500, St. Marys River at Great Mills, Md.

Number of base-flow observations used -- 13

Base-flow observations used, made in 1966-67, 1977-82

Equivalent years of record --
Coefficient of determination $\left(R^{2}\right)--0.80$

Standard error of estimate (SE) -- 38 percent

Minimum observed discharge used in correlation -- $0.0 \mathrm{ft}^{3} / \mathrm{s}$ (3 observations)

Remarks. Observations of flow less than $0.05 \mathrm{ft}^{3} / \mathrm{s}$ ( 5 observations) were not used in regression analysis. 
Table 12.--Basin characteristics and low-flow characteristics at partial-record streamflow-gaging stations in Maryland and Delaware--Continued

01660905 Zekiah Swamp Run near Malcolm, Md.

Location: Lat $38^{\circ} 36^{\prime} 52^{\prime \prime}$, long $76^{\circ} 49^{\prime} 59^{\prime \prime}$, Charles County, at bridge on State Highway 382 , 2.4 mi west of Malcolm.

Basin characteristics:

$\begin{array}{lrl}\text { Drainage area } & 12.1 \mathrm{mi}^{2} \\ \text { Length } & 6.3 \mathrm{mi} \\ \text { Slope } & 14.8 \mathrm{ft} / \mathrm{mi} \\ \text { Elevation } & 196 & \mathrm{ft} \\ \text { Storage } & 0.06 \text { percent }\end{array}$

Forest

Precipitation 44.5 in.

A Soil ND

D Soil

ND

Low-flow characteristics:

$$
\begin{aligned}
& \begin{array}{l}
\text { Discharge } \\
\left(\mathrm{ft}^{3} / \mathrm{s}\right)
\end{array} \\
& \text { 7-day } \\
& \text { 14-day } \\
& \text { 30-day }
\end{aligned}
$$

\begin{tabular}{|c|c|c|}
\hline 2-year & 0-year & 20 -year \\
\hline 0.9 & 0.0 & 0.0 \\
\hline 1.2 & 0.0 & 0.0 \\
\hline 1.6 & 0.0 & 0.0 \\
\hline
\end{tabular}

Basis of low-flow estimates:

Correlated with 01661500, St. Marys River at Great Mi11s, Md.

Number of base-flow observations used -- 14

Base-flow observations used made in 1975-82

Equivalent years of record --
Coefficient of determination $\left(\mathrm{R}^{2}\right)--0.89$

Standard error of estimate (SE) - 51 percent

Minimum observed discharge used in correlation -- $0.0 \mathrm{ft}^{3} / \mathrm{s}$ ( 3 observations)

Remarks. Observations of flow less than $0.05 \mathrm{ft}^{3} / \mathrm{s}$ ( 4 observations) were not used in regression analysis.

03075400 Laurel Run at Crellin, Md.

Location: Lat $39^{\circ} 23^{\prime} 04^{\prime \prime}$, long $79^{\circ} 28^{\prime} 25^{\prime \prime}$, Garrett County, 800 ft above mouth, 0.5 mi southwest of Crellin.

Basin characteristics:

$\begin{array}{lrl}\text { Drainage area } & 10.9 \mathrm{mi}^{2} \\ \text { Length } & 6.0 \mathrm{mi} \\ \text { Slope } & 78.2 \mathrm{ft} / \mathrm{mi} \\ \text { Elevation } & 2,680 & \mathrm{ft} \\ \text { Storage } & 0.26 \text { percent }\end{array}$

Forest

Precipitation 50.5 in.

$\begin{array}{ll}\text { A Soil } & \text { ND } \\ D \text { Soil } & \text { ND }\end{array}$

Storage

0.26 percent

\begin{tabular}{|c|c|c|}
\hline 2-year & 10-year & 20-year \\
\hline 1.9 & 0.5 & 0.4 \\
\hline 2.1 & 0.6 & 0.4 \\
\hline 2.8 & 0.9 & 0.6 \\
\hline
\end{tabular}

D Soi

Low-flow characteristics:

$$
\begin{aligned}
& \text { Discharge } \\
& \left(\mathrm{ft}^{3} / \mathrm{s}\right) \\
& \begin{array}{c}
7-\text { day } \\
14-\text { day } \\
30-\text { day }
\end{array}
\end{aligned}
$$

Basis of low-flow estimates:

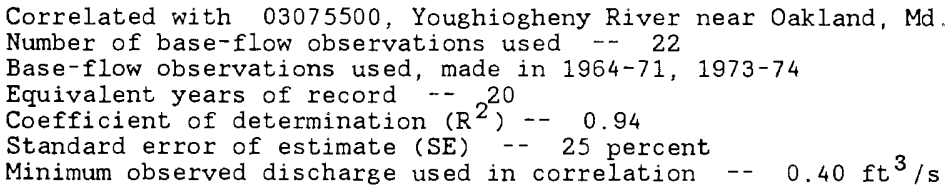


Table 12.--Basin characteristics and low-flow characteristics at partial-record streamflow-gaging stations in Maryland and Delaware--Continued

03075475 Little Youghiogheny River at Loch Lynn Heights, Md.

Location (Revised): Lat $39^{\circ} 23^{\prime} 54^{\prime \prime}$, long $79^{\circ} 22^{\prime} 11 "$, Garrett County, at bridge on State Highway 135 , 0.4 mi northeast of Loch Lynn Heights.

Basin characteristics:

Drainage area

Length

Slope

Elevation

Storage

$\begin{array}{rl}13.2 & \mathrm{mi}^{2} \\ 6.5 & \mathrm{mi} \\ 22.1 & \mathrm{ft} / \mathrm{mi} \\ 2,640 & \mathrm{ft} \\ 0.26 & \text { percent }\end{array}$

Forest

Precipitation

A Soil

D Soil

Low-flow characteristics:

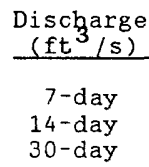

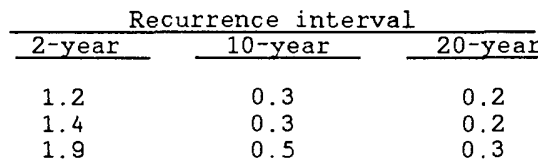

Basis of low-flow estimates:

Correlated with 03075500, Youghiogheny River near Oakland, Md.

Number of base-flow observations used -- 11

Base-flow observations used, made in 1975-79

Equivalent years of record -- 16

Coefficient of determination $\left(\mathrm{R}^{2}\right)-0.94$

Standard error of estimate (SE) - 25 percent

Minimum observed discharge used in correlation -- $1.02 \mathrm{ft}^{3} / \mathrm{s}$

03075700 Muddy Creek at Swallow Fal1s State Park, Md.

Location: "Lat $39^{\circ} 30^{\prime} 05^{\prime \prime}$, long $79^{\circ} 25^{\prime} 08^{\prime \prime}$, Garrett County, at bridge in Swallow Falls State Park, 0.1 mi above mouth, and $6.7 \mathrm{mi}$ north of Oakland.

Basin characteristics:

$\begin{array}{lrl}\text { Drainage area } & 17.8 \mathrm{mi}^{2} \\ \text { Length } & 7.4 \mathrm{mi} \\ \text { Slope } & 32.2 \mathrm{ft} / \mathrm{mi} \\ \text { Elevation } & 2,720 & \mathrm{ft} \\ \text { Storage } & 5.37 \text { percent }\end{array}$

$\begin{array}{lr}\text { Forest } & 66 \text { percent } \\ \text { Precipitation } & 49.5 \text { in. } \\ \text { A Soil } & \text { ND } \\ \text { D Soil } & \text { ND }\end{array}$

Low-flow characteristics:

$$
\begin{gathered}
\begin{array}{c}
\text { Discharge } \\
\text { (ft } \left.\mathrm{ft}^{3} / \mathrm{s}\right)
\end{array} \\
\begin{array}{c}
7 \text {-day } \\
\text { 14-day } \\
30-\text { day }
\end{array}
\end{gathered}
$$

Basis of low-flow estimates:

Correlated with 03076600 , Bear Creek at Friendsville, Md

Number of base-flow observations used -- 10

Base-flow observations used, made in 1979-82

Equivalent years of record --
Coefficient of determination $\left(R^{6}\right)--0.86$

Standard error of estimate (SE) -- 31 percent

Minimum observed discharge used in correlation -- $3.30 \mathrm{ft}^{3} / \mathrm{s}$ 
Table 12,--Basin characteristics and low-flow characteristics at partial-record streamflow-gaging stations in Maryland and Delaware--Continued

\section{Cherry Creek near McHenry, Md.}

Location: Lat $39^{\circ} 32^{\prime} 20^{\prime \prime}$, long $79^{\circ} 18^{\prime} 55^{\prime \prime}$, Garrett County, 200 ft east of Rock Lodge Road, 2.4 mi southeast of McHenry.

Basin characteristics:

$\begin{array}{lrllc}\text { Drainage area } & 12.3 \mathrm{mi}^{2} & \text { Forest } & 72 \text { percent } \\ \text { Length } & 8.1 \mathrm{mi} & \text { Precipitation } & 48.0 \text { in. } \\ \text { Slope } & 14.2 \mathrm{ft} / \mathrm{mi} & \text { A Soil } & \text { ND } \\ \text { Elevation } & 2,740 & \mathrm{ft} & \text { D Soil } & \text { ND } \\ \text { Storage } & 6.68 \text { percent } & & \end{array}$

Low-flow characteristics:

$$
\begin{aligned}
& \begin{array}{c}
\text { Discharge } \\
\left(\mathrm{ft}^{3} / \mathrm{s}\right)
\end{array} \\
& \text { 7-day } \\
& \text { 14-day } \\
& \text { 30-day }
\end{aligned}
$$

Basis of low-flow estimates:

Correlated with 03078000, Casselman River at Grantsville, Md.

Number of base-flow observations used -- 17

Base-flow observations used, made in 1973, 1975-79

Equivalent years of record -. 10

Coefficient of determination $\left(\mathrm{R}^{2}\right)-0.92$

Standard error of estimate (SE) - 29 percent

Minimum observed discharge used in correlation -- $0.86 \mathrm{ft}^{3} / \mathrm{s}$

03076580 South Branch Bear Creek near Accident, Md.

Location: Lat $39^{\circ} 36^{\prime} 39^{\prime \prime}$, long 79 $20^{\prime} 02^{\prime \prime}$, Garrett County, at culvert on U.S. Highway $219,1.5$ mi southwest of Accident.

Basin characteristics:

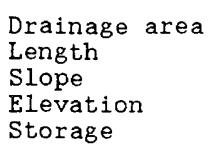

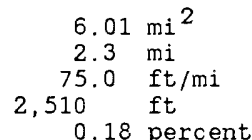

Forest

33 percent

Length

Storage

0.18 percent
Precipitation 48.0 in

$\begin{array}{ll}\text { A Soil } & \text { ND } \\ \text { D Soil } & \text { ND }\end{array}$

\section{1}

\begin{tabular}{|c|c|c|}
\hline \multicolumn{3}{|c|}{ nce int } \\
\hline 0. & 0.2 & 0.2 \\
\hline & 0.3 & 0.2 \\
\hline 0.6 & 0.3 & 0.3 \\
\hline
\end{tabular}

Low-flow characteristics:

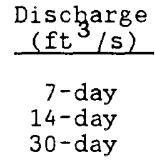

Basis of low-flow estimates:

Correlated with 03076600, Bear Creek at Friendsville, Md.

Number of base-flow observations used -. 18

Base-flow observations used, made in 1965-74

Equivalent years of record -- 10
Coefficient of determination $\left(\mathrm{R}^{2}\right)-0.89$

Standard error of estimate (SE) - 24 percent

Minimum observed discharge used in correlation -- $0.16 \mathrm{ft}^{3} / \mathrm{s}$ 
Table 12.--Basin characteristics and low-flow characteristics at partial-record streamflow-gaging stations in Maryland and Delaware--Continued

03076590 South Branch Bear Creek near Friendsvi11e, Md.

Location: Lat $39^{\circ} 39^{\prime} 11^{\prime \prime}$, long $79^{\circ} 23^{\prime} 06^{\prime \prime}$, Garrett County, at bridge on Accident-Friendsville Road, 1.2 $\mathrm{mi}$ southeast of Friendsvillé.

Basin characteristics:

$\begin{array}{lrllc}\text { Drainage area } & 16.8 \mathrm{mi}^{2} & \text { Forest } & 50 \text { percent } \\ \text { Length } & 7.4 \mathrm{mi} & \text { Precipitation } & 48.5 \text { in. } \\ \text { Slope } & 109 & \mathrm{ft} / \mathrm{mi} & \text { A Soil } & \text { ND } \\ \text { Elevation } & 2,410 & \mathrm{ft} & \text { D Soil } & \text { ND } \\ \text { Storage } & 0.14 \text { percent } & & \end{array}$

Low-flow characteristics:

Discharge
$\frac{\left(\mathrm{ft}^{3} / \mathrm{s}\right)}{7-\text { day }}$
$\begin{aligned} & 14-\text { day } \\ & 30-\text { day }\end{aligned}$

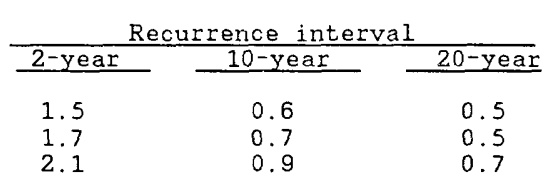

Basis of low-flow estimates:

Correlated with 03076600, Bear Creek at Friendsville, Md.

Number of base-flow observations used -- 12

Base-flow observations used, made in 1975 79

Equivalent years of record -- 9
Coefficient of determination $\left(\mathrm{R}^{2}\right)-0.96$

Standard error of estimate (SE) - 17 percent

Minimum observed discharge used in correlation -- $1.76 \mathrm{ft}^{3} / \mathrm{s}$

03077925 North Branch Casselman River near Grantsville, Md.

Location: Lat $39^{\circ} 40^{\circ} 08^{\prime \prime}$, long $79^{\circ} 10^{\prime} 43^{\prime \prime}$, Garrett County, at bridge on State Highway $495,2.3 \mathrm{mi}$ southwest of Grantsville.

Basin characteristics:

$\begin{array}{lrllc}\text { Drainage area } & 24.4 \mathrm{mi}^{2} & \text { Forest } & 66 \text { percent } \\ \text { Length } & 14.9 \mathrm{mi} & \text { Precipitation } & 45.5 \text { in. } \\ \text { Slope } & 29.7 \mathrm{ft} / \mathrm{mi} & \text { A Soil } & \text { ND } \\ \text { Elevation } & 2,610 \mathrm{ft} & \text { D Soil } & \text { ND } \\ \text { Storage } & 2.10 \text { percent } & & \end{array}$

Low-flow characteristics:

Discharge
$\frac{\left(\mathrm{ft}^{3} / \mathrm{s}\right)}{\text { 7-day }}$
$\begin{aligned} & \text { 14-day } \\ & \text { 30-day }\end{aligned}$

\begin{tabular}{|c|c|c|}
\hline \multicolumn{3}{|c|}{ Recurrence interval } \\
\hline & & \\
\hline $\begin{array}{l}2.4 \\
2.9 \\
4.9\end{array}$ & $\begin{array}{l}0.8 \\
0.9 \\
1.4\end{array}$ & $\begin{array}{l}0.6 \\
0.7\end{array}$ \\
\hline
\end{tabular}

Basis of low-flow estimates:

Correlated with 03078000 , Casselman River at Grantsville, Md.

Number of base-flow observations used -- 11

Base-flow observations used, made in 1975-79

Equivalent years of record -- 20

Coefficient of determination $\left(\mathrm{R}^{2}\right)--0.99$

Standard error of estimate (SE) - 9 percent

Minimum observed discharge used in correlation -- $3.58 \mathrm{ft}^{3} / \mathrm{s}$ 
Table 12,--Basin characteristics and low-flow characteristics at partial-record streamflow-gaging stations in Maryland and Delaware--Continued

03077950 South Branch Casselman River near Grantsville, Md.

Location: Lat $39^{\circ} 40^{\prime} 05^{\prime \prime}$, long $79^{\circ} 10^{\prime} 42^{\prime \prime}$. Garrett County, 250 ft upstream from confluence with North Branch Cassélman River, 2.2 mi southwest of Grantsvilie.

Basin characteristics:

Drainage area
Length
Slope
Elevation
Storage

$\begin{array}{rl}20.8 & \mathrm{mi}^{2} \\ 8.4 & \mathrm{mi} \\ 50.5 & \mathrm{ft} / \mathrm{mi} \\ 2,610 & \mathrm{ft} \\ 0.03 & \text { percent }\end{array}$

Forest 68 percent

Precipitation 45.5 in.

$\begin{array}{ll}\text { A Soil } & \text { ND } \\ \text { D Soil } & \text { ND }\end{array}$

Storage 0.03 percent

Low-flow characteristics:

$$
\begin{gathered}
\begin{array}{c}
\text { Discharge } \\
\left(\mathrm{ft}^{3} / \mathrm{s}\right)
\end{array} \\
\begin{array}{c}
7-\text { day } \\
14-\text { day } \\
30-\text { day }
\end{array}
\end{gathered}
$$

\begin{tabular}{|c|c|c|}
\hline 2-year & 10-year & 20 -year \\
\hline 0.9 & 0.2 & 0.1 \\
\hline 1. 1 & 0.2 & 0.2 \\
\hline 1.7 & 0.4 & 0.3 \\
\hline
\end{tabular}

Recurrence interval

Basis of low-flow estimates:

Correlated with 03078000 , Casselman River at Grantsville, Md.

Number of base-flow observations used -- 11

Base-flow observations used, made in 1975-79

Equivalent years of record -- 16

Coefficient of determination $\left(R^{2}\right)-0.98$

Standard error of estimate (SE) -- 17 percent

Minimum observed discharge used in correlation -- $1.56 \mathrm{ft}^{3} / \mathrm{s}$ 